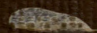



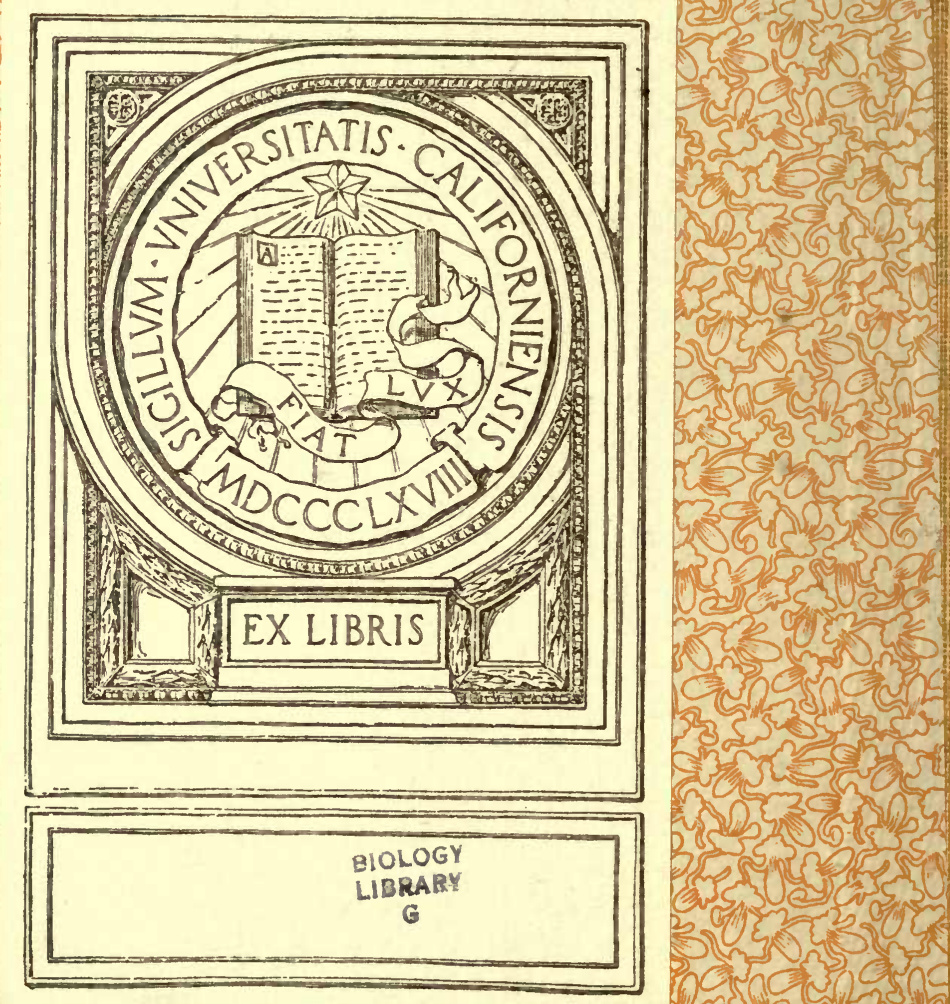

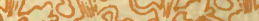

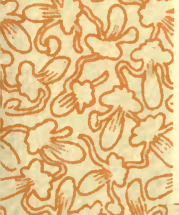

SO. 
20. S r. 00 . त.

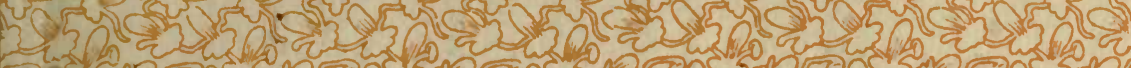

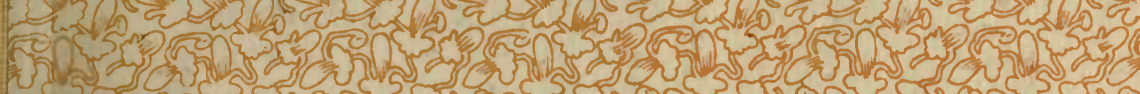

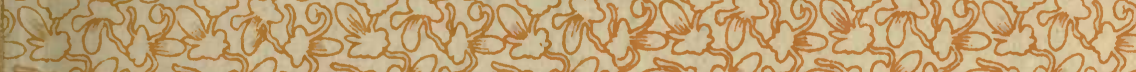

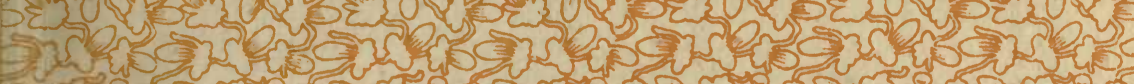

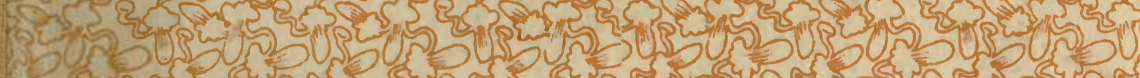
190 के

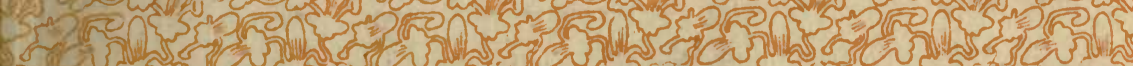

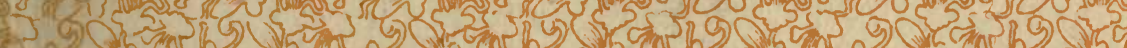
3 हn 3 है 2.53 .

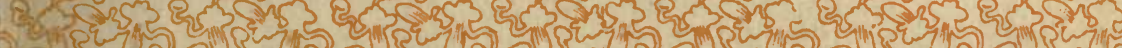

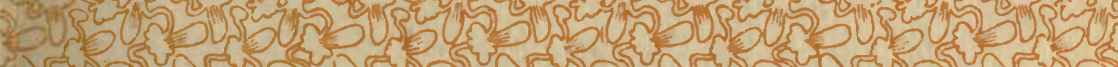
5. 150 , 3.

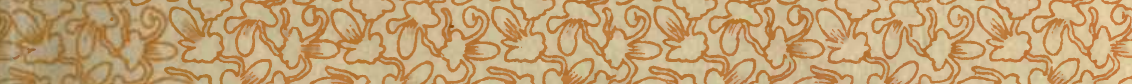

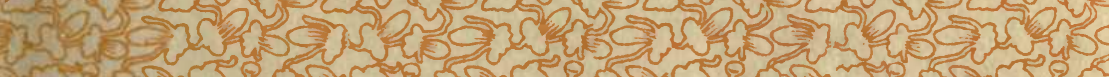

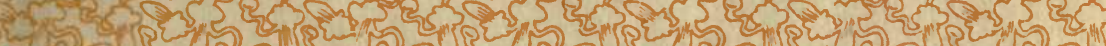
1200325

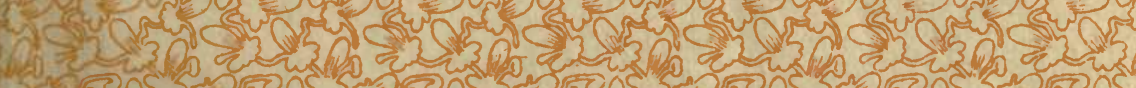

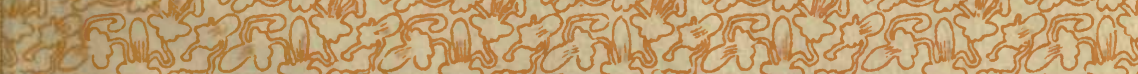

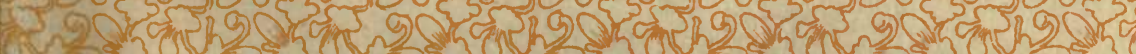
(1) है। 2 है 3 .

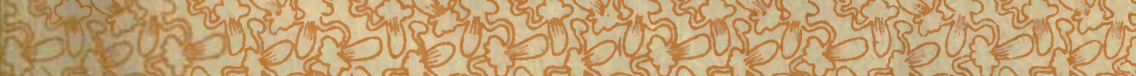
2. 3 है

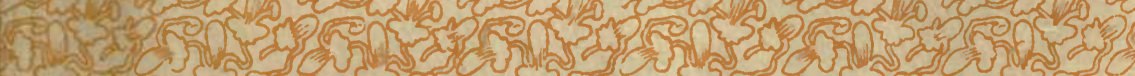

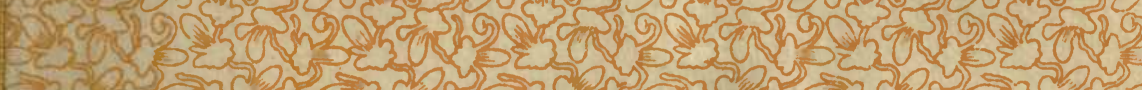

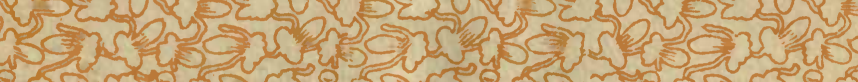

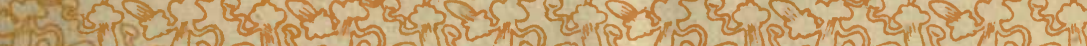

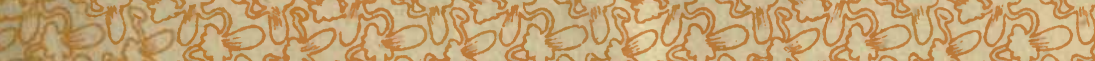
1 30 की Nof 5 र

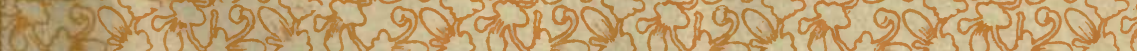

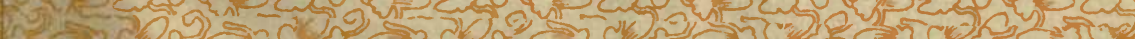

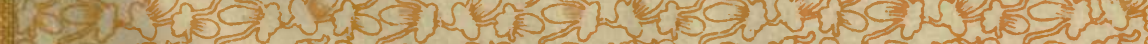



THE

\section{MICROSCOPIC „ANA'TOMY}

\section{ri \\ THE HUMAN BODY,}

$\mathbf{I N}$

HEALTH AND DISEASE.

ILLUSTRATED WITH UPWARDS OF 400 DRAWINGS IN COLOUR.

BY

ARTHUR HILL HASSALL M.D. LOND AUTHOR OF

A "history OF THE bRITISH FRESHWATER ALGA;" LICENTIATE OF THE ROYAL COILEGE OF PHYSICIANS OF LONDON; FELLOW OF THE LINNAEAN SOCIETY;

MEMBER OF THE ROTAL COLLEGE OF SURGEONS OF ENGLAND; ONE OF THE COUNCIL OF THE EPIDEMIOLOGICAL SOCIETT, ALSO OF THE BOTANICAL SOCIETY OF LONDON; CORRESPONDING MEMBER OF THE DUBLIN NATURAL HISTORY SOCIETY; PHYSICIAN TO THE UNITED KINGDOM LIFE ASSURANCE COMPANY.

IN TWO VOLUMES.

VOL. II.

LONDON :

TAYLOR, WALTON, AND MABERLY, UPPER GOWER STREET; AND IVY LANE, PATERNOSTER ROW. 



\section{THOMAS WAKLEY, ESQ., M.P.,}

CORONER, ETC. ETC.

\section{Dear Sir,}

To you I dedicate the accompanying pages, devoted to the elucidation of a department of minute anatomy of daily increasing interest and importance.

I thus dedicate this work to you on two grounds; the one personal and private, the other public.

On my mentioning the design of this work to you - and you were one of the first persons to whom it was mentioned - you were kind enough to express yourself in terms of approval and encouragement, and to proffer any assistance in your power in the furtherance of my undertaking. Of this conduct on 
your part I have ever entertained a pleasing and grateful remembrance; and it is this which constitutes the private ground of my dedication.

But I dedicate this work to you on a higher and more important ground. I have for many years seen in you the able and strenuous advocate - amidst much obloquy and misrepresentation - of the rights of that profession of which we are both members : on this high ground I conceive you to be entitled to the gratitude of your professional brethren; and with this feeling on my mind of your conduct and services in a good cause,

I beg to subscribe myself,

Yours, very faithfully, THE AUTHOR. 


\section{P R E A A E.}

ArTer three years of more or less constant labour, the welcome and often-wished-for period of the completion of this work has arrived, and the author is at liberty to address himself to his readers, and to explain the motives and the circumstances which have led to its production.

The idea of this work presented itself to the author's mind several years since; it was not, however, until about the period above referred to, that its actual execution was commenced.

At the time when its design was first conceived, the powers of the microscope in developing organic structure were but beginning to be known and appreciated, and the importance of its application to physiology and pathology was but dimly perceived.

At that period, also, but few complete works devoted to microscopic anatomy had appeared in any language, native or foreign; more recently this deficiency, as respects France and Germany, has been well supplied by the appearance of several original works, as those of Donné, Mandl, Lebert, Müller, Henle, Vogel, Gerber, and Wagner; England, however, has not as yet contributed her share of distinct and independent works on general anatomy: not that our observers have been idle, or have neglected a field of inquiry so interesting and important, resting satisfied with mere translations : a whole host of intelligent and able microscopists have applied themselves to the investigation of the ultimate 
structure of the several tissues and organs, and this with a pre-eminent degree of success. Amongst the more remarkable of these investigators the following may be enumerated: Gulliver, Martin Barry, Busk, Addison, Kiernan, Sharpey, Goodsir, Tomes, Toynbee, Johnson, Simon, Todd and Bowman, Quekett, Erasmus Wilson, Hughes Bennett, Carpenter, Rainey, Handfield Jones, and Gairdner.

The results of the labours of these observers have not as yet, however, been embodied in a separate work; but some of them have been mixed up with works on descriptive anatomy and physiology, as in Sharpey's edition of Quain's Anatomy, in Carpenter's "Principles" and "Manual" of Physiology, and in Todd and Bowman's " Physiological Anatomy." The last is an admirable book, full of original research and important facts.

Now, one of the purposes, the accomplishment of which has been attempted in the following pages, has been the collecting together of the numerous communications on general anatomy to be found scattered through the pages of our different scientific periodicals, and their combination into a whole.

The further objects which the author has had in view in the production of this work have been simplicity of description, fidelity of representation, and the addition of such facts and particulars as have occurred to himself in the course of his own investigations; and he may take this opportunity of observing, that in but few instances has he written upon a subject without previous investigation.

That a work similar in character to the present was needed is proved by the foregoing details; and that the objects above referred to have been, to some extent at least, accomplished, is shown by the favourable reception which has hitherto been accorded to this undertaking.

The author considers it right, in justice to himself, that certain disadvantages under which the work has been pro- 
duced should be mentioned: these were, constant engagement in general practice, much anxiety, and, though last not least, ill health. These would have been sufficient to have deterred many from the undertaking altogether. Although this has not been the effect upon the author, yet it cannot be questioned but that they have operated in some respects to the disadvantage of the work; and he begs that it may be taken neither as the measure of that of which the subject is capable, nor of the author's powers of observation and description exercised under more favourable circumstances of health, leisure, and feeling.

The author makes these few remarks not in order to deprecate any fair criticism, but simply that the truth in reference to the production of this work may be known in justice both to the writer and the reader.

Having said thus much in relation to the work itself, the author has now the pleasing task of returning his acknowledgments to those who have in any way assisted him in his laborious though most agreeable task; these are particularly due to the following: Mr. Quekett, Dr. Handfield Jones, Professor Sharpey, Mr. Tomes, Mr. Bowman, Mr. Busk, Professor Owen, Mr. Canton, Dr. Carpenter, Dr. Letheby, Dr. Robert Barnes, Mr. Ransom, Mr. Pollock, and Mr. Gray, of St. George's Hospital, Mr. Hett, and Mr. Andrew Ross: they are also due to Mr. Drewry Ottley; Dr. Radcliffe Hall; Mr. Coppin, of Lincoln's Inn; Messrs. Welch and Jones, of Dalston; Mr. Berry, of James Street, Covent Garden; Mr. Cowdry, of Great Torrington; Dr. Jones, of Brighton; Dr. Chambers, of Colchester; Mr. Milner, of Wakefield; $\mathrm{Mr}$. Walker, of St. John's Street Road; Mr. Ringrose, of Potter's Bar; Dr. Halpin, of Cavan; and Mr. H. Hailey, of Birmingham.

To Dr. Letheby I hope shortly to have a second opportunity of rendering my thanks, in connection, viz., with the work on crystals, entitled "Human Crystallography," an 
announcement of which appeared some months since, and towards the completion of which considerable materials have already been collected.

To Mr. Hett my thanks are especially due for having, at considerable trouble and inconvenience, furnished me with very many of the injections required to illustrate Part XV. of the "Microscopic Anatomy;" these, together with numerous other injected preparations of that gentleman which I have seen, have been of first-rate quality; and the microscopic anatomist has reason to hail the advent of such a man to the cause of general anatomy with the highest satisfaction.

To Mr. Andrew Ross, on this, as on a former occasion, I have to express my obligations, Mr. R. having at all times furnished me with any information $I$ might require, as well as provided me with any necessary apparatus.

Thus much for friends. If in the inditing of this work I have made a single enemy I am sorry for it, and still more so if I have given any real occasion for offence. If in differing from other observers as to certain facts and conclusions I have expressed myself in such a manner as to wound their feelings, as in one or two instances I fear I may have done, I much regret it: the differences amongst men whose common aim is the knowledge of truth as manifested in the works of creation should never be deep or lasting; for this community of purpose should ever be a firm bond of union between such men, seekers after truth, and should displace from their minds the lesser and grosser feelings of rivalry and ill-will.

Notting Hill, July 27 th, 1849 . 


\section{CONTENTS.}

\section{PAR'T I.}

\section{FLUIDS OF THE HUMAN BODY.}

\section{Article I.}

The Lympi and Chyse. General description of Lymphatics and Lacteals, 1. Characters and Structure of Lymph, 4. Ditto of Chyle, 5. Ditto of Fluid of Thoracic Duct, 7. Corpuscles of Thymus, 9.

\section{Article II.}

The Broov. Definition, 13. Coagulation of the Blood, without the Body, 14. Formation of the Clot, 15. Formation of the Buffy Coat of the Blood, 18. Cupping of the Clot, 20. Coagulation of the Blood in the Vessels after Death, 21. Signs of Death, 21. Globules of the Blood, 24. The Red Globules, 25. The White Globules, 39. Molecules of the Blood, 64. Blood Globules of Reptiles, Fishes, and Birds, 66. Capillary Circulation, 69. Circulation in the Embryo of the Chick, 74. Venous and Arterial Blood, 80. Modifications of the Blood Corpuscles the results of different external Agencies, 85. Modifications, the results of Decomposition occurring in Blood abandoned to itself without the Body, 86. Modifications, the results of Decomposition occurring in Blood within the Body after Death, 87. Causes of Inflammation, 87. Pathology of the Blood, 89. Importance of a Microscopic Examination of the Blood in Criminal Cases, 116.

Article III.

Mucus, 122. General characters, 122. Mucous Corpuscles, 126. Nature of Mucous Corpuscles, 129. The Mucus of different Organs, 132. 


\section{Article IV.}

Pus, 137. General characters, 137. Identity of the Pus and Mucous Corpuscle, 138. Distinetive characters of Mucus and Pus, 141. Distinctions between certain forms of Mucus and Pus, 146. Detection of Pus in the Blood, 147. False Pus, 149. Metastatic Abscesses, 149 Venereal Vibrios, 150.

\section{Article V.}

MıLK, 153. Serum of the Milk, 154. The Globules, 155. Colostrum, 160. Pathological Alterations of the Milk, 163. The Milk of Unmarried Women, 167. The Milk of Women previous to Confinement, 167. The Milk of Women who have been delivered, but who have not nursed their Offspring, 169. Milk in the Breasts of Children, 169. Different kinds of Milk, 169. Good Milk, 171. Poor Milk, 174. Rich Milk, 175. Adulterations of Milk, 176. Formation of Butter, 177. Modifications of Milk abandoned to itself, and in which Putrefaction has commenced, 178. The Occurrence of Medicines, \&c. in the Milk, 180.

\section{Article VI.}

The Semen, 181. Spermatozoa, Form, Size and Structure of, 182. Motions of the Spermatozoa, 189. Spermatophori, 193. Development of the Spermatozoa, 195. The Spermatozoa essential to Fertility, 198. Pathology of the Seminal Fluid, 201. Application of a Microscopic Examination of the Semen to Legal Medicine, 204.

\section{Article VII.}

Saliva. - Bile. - Sweat. - Urine, 207. The Saliva, 208. The Bile, 210. The Sweat, 211. The Urine, 213. Pathology of the Urine, 215.

PART II.

\section{SOLIDS OF THE HUMAN BODY.}

\section{Article VIII.}

FAt, 222. Form, Size and Structure of the Fat Corpuscle, 222. Distribution of Fat, 229. Disappearance of, 231.

\section{Article IX.}

Epithelium, Distribution of, 233. Tessellated Epithelium, Structure of, 235. Conoidal Epithelium, naked and ciliated Structure of, 237. Development and Multiplication of Epithelium, 242. Nutrition of Epithelium, 243. Destruction and Renewal of Epithelium, 243. 


\section{Article X.}

Eridermis, Distribution, Form, Structure, and Development of, 247. Epidermis of the White and Coloured Races, 250. Destruction and Renewal of Epidermis, 250.

\section{Article XI.}

The NaILS, Structure of, 253. Development of, 255.

\section{Article XII.}

Pigment Cells, Structure and Varicties of, 257.

\section{Article XIII.}

Harr, Form of, 263. Size of, 264. Structure of, 264. Growth of, 271. Regeneration of, 272, Nutrition of, 273. Distribution of, 274. Colour of, 276. Properties of, 277. The Hair of different Animals, 278.

\section{Article XIV.}

Cartilages, 281. True Cartilages, 281. Fibro-Cartilages, 285. Nutrition of Cartilage, 287. Growth and Development of Cartilage, 289.

\section{Artiche XV.}

Bone, Structure of, 294. Growth and Development of, 303. Accidental Ossification, 313.

\section{Article XVI.}

TeEti, Structure of, 314. Development of, 319. Caries of, 325. Tartar on, 326.

\section{Article XVII.}

Cellular or Frbrous Tissue, 327. Inelastic or White Fibrous Tissue, 328. Elastic or Yellow Fibrous Tissue, 329. Development of Fibrous Tissue, 334.

\section{Article XVIII.}

Muscle, 336. Structure of Muscle, 337. Structure of the Unstriped Muscular Fibrilla, 337. Structure of the Striped Muscular Fibre, 339. Union of Muscle with Tendon, 346. Muscular Contraction, 346. Development of Muscle, 351.

\section{Artiche XIX.}

Nerves, 356. Structure of, 356. Cerebro-Spinal System. Secreting or Cellular Structure of, 356. Tubular Structure of, 359. Sympa. thetic System, 361. Gelatinous Nerve, Fibres of : 362. Structure of 
Ganglia, 365. Origin and Termination of Nerves, 366. Pacinian Bodies, 368. Development and Regeneration of Nervous Tissue, 371. Researches of M. Robin, 374.

\section{Article XX.}

Organs of Respiration, 378. Aeriferous Apparatus. Bronchial Tubes, and Air Cells, 379. Vascular Apparatus, 381. Pathology, 383.

\section{Article XXI.}

Glands, 388. Classification of Glands, 391. A. Follicles, 393. Stomach Tubes, 395. Fallopian and Uterine Tubes, 396. Solitary Glands, 397. Aggregated Glands, 398. B. Sebaceous Glands, 398.; comprising the Meibomian Glands, 400. Glands of Hair Follicles, 401., the Curuncula Lachrymalis, 402. Glands of Nipple, 402., and Glands of Prepuce, 403. Mucous Glands, 403.; including the Labial, Buccal, Lingual, Tonsilitic, Tracheal, and Bronchial Glands; also the Glands of the Uvula, Brunner's and Cowper's Glands, 403. Brunner's Glands, 406. Cowper's Glands, 407. c. Salivary Glands, 407. Lachrymal Glands, 408. Mammary Glands, 408. Liver, Structure of, 409. Pathology of, 419. Prostate Gland, 422. D. Sudoriferous Glands, 424. Axillary Glands, 426. New Tubular Gland in Oxilla, Plate LVII., fig. 4 b. Ceruminous Glands, 427. Kidneys, 427. Secreting Apparatus of, including Tubes, Malpighian Bodies, and Epithelial Cells, 428. Vascular Apparatus of, 431. Development of the Kidney, 436. Pathology of, 442. Testis, 475. E. Thymus Gland, 477. Thyroid Gland, 479. Supra-renal Capsules, 481. Spleen, 483. F. Absorbent Glands, 486. Villi of the Intestines, 487.

\section{Article XXII.}

Organs of the Senses, 491. Touch: Papillary Structure of the Skin, 491. TAste : Papillary Structure of the Mucous Membrane of the Tongue, 494. Smell: Structure of the Mucous Membrane of the Nose, 500. Vision : Structure of the Globe of the Eye, 505. Schlerotic, 505. Cornea, 506. Choroid, 511. Retina ; 516. Vitreous Body; 519. Crystalline Lens, 520. Hearing: Organ of, 522. External Ear, 522. Middle Ear, 523. Internal Ear, 525.

\section{APPENDIX.}

Pituitary Gland, 534. Pineal Gland, 535. Pia Mater, 537. Pacchionian Glands, 538. Development of the Fat Vesicle, 538. On the Structure and Formation of the Nails, 541. On the Ganglionic Character of the Arachnoid Membrane, 544. Structure of the Striped Muscular Fibrilla, 548. Structure of the Bulb of the Hair, 549. Synovial Fringes, 549. Structure of the Sudoriparous Glands, 549. 


\section{INDEX OF THE ILLUSTRATIONS.}

THE WHOLE OF THE FOLLOWING ILLUSTRATIONS ARE ORIGINAL WITH BUT NINE EXCEPTIONS.

\section{BLOOD.}

Corpuscles of man, the red with the centres clear,

670 diam. - - - - - - Plate 1. Fig. 1

The same, the red with the centres dark, 670 diam. - - I. -2

The same, seen in water, 670 diam. - - - - I. - 3

The same, the red united into rolls, 670 diam. - _ - - I. - 4

Tuberculated condition of the red corpuscles, 670 diam. - I. -5

White corpuscles of man, in water, 670 diam. - $\quad-\quad$ I. -6

Corpuscles of frog, 670 diam. - - - - - - - II. - 1

The same, with the nucleus of the red visible, 670 diam. - II. -2

The same, in water, 670 diam. - _ - - - I. - 3

The same, after prolonged action of water, $670 \mathrm{diam}$. - - II. - 4

Nuclei of red corpuscles of frog, 670 diam. - - - - Ir. - 5

Elongation of red corpuscles of ditto, $670 \mathrm{diam}$. $\quad-\quad$ I. $\quad-6$

Corpuscles of the dromedary, 670 diam. - - - - - IIr. - 1

The same of the siren, 670 diam. $\quad$ - $\quad$ - $\quad-\quad$ - III. $\quad$ - 2

The same of the alpaco, 670 diam. $\quad$ - $\quad$ - $\quad-\ldots$ IIr. $\quad-3$

The same of the elephant, 670 diam. - - - - - Iv. - 1

The same of the goat, 670 diam. $\quad$ - $\quad$ - - Iv. $\quad 2$

Peculiar concentric corpuscles in blood, 670 diam. - - - vv. - 3

Coagulated fibrin, 670 diam. - - $\quad$ - $\quad$ - $\quad$ - - Iv. - 4

The same with granular corpuscles, $670 \mathrm{diam}$. - - - Iv. - 5

Corpuscles of earth-worm, 670 diam. - - - - - Iv. - 6

Circulation in tongue of frog, $350 \mathrm{diam}$. $\quad-\quad-\quad-\mathrm{v} . \quad-1$

The same in web of the foot of ditto, 350 diam. - - v. -2

Corpuscles in vessels of the same, $670 \mathrm{diam}$. - - - - vI. - 1

White corpuscles in vessels of the same, 900 diam. - - vr. - 2

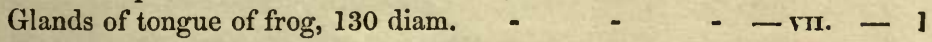

Under surface of tongue of same, 500 diam. - $\quad-\quad$ vIr $\quad 2$ 
Red corpuscles of embryo of fowl, 670 diam. The same, in water, 670 diam.

Red corpuscles of adult fowl, 670 diam.

The same of young frog, 670 diam.

The same of the adult frog, 670 diam. -

The same united into chains, 670 diam.
- Plate 1x. Fig. 1

- - Ix. - 2

- $-\mathrm{Ix} . \quad 3$

- - Ix. -4

- - Ix. -5

- $-\mathrm{Ix} .-6$

\section{DEVELOPMENT OF EMBRYO OF CHICK.}

The cicatricula prior to incubation

The same at the end of first day of incubation

The same at the thirty-sixth hour

The same at the close of the second day -

The same at the end of the third day -

The embryo on the conclusion of the fourth day

The same at the termination of the fifth day -

The embryo of six days old - - -

The embryo of the ninth day of development -

The same at the end of the seventh day, detached

Ditto at the end of the ninth day, also detached

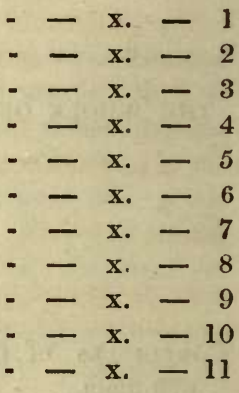

\section{MUCUS.}

Corpuseles of, in their ordinary condition, 670 diam. - - XI. - 1

The same collapsed, 670 diam. $\quad$ - $\quad$ - $\quad-\quad$ xr. $\quad-2$

The same, showing the action of water, 670 diam. - - XI. - 3

The same acted on by dilute acetic acid, 670 diam. - - xr. - 4

The same after the action of undilute acetic acid, 670 diam.

The same in process of development, 670 diam.

Vaginal mucus, 670 diam.

Esophageal mucus, 670 diam. -

Bronchitic ditto, 670 diam. -

Vegetation in mucus, 670 diam.

Mucus of stomach, 670 diam.

Vaginal tricho-monas

- $-\mathrm{xr}-5$

- $-\mathrm{xI}$. 6

- $-\mathrm{xIr}-1$

- - xIr. -2

- - xIr. -3

- - хाr. -4

- XIr. - 5

- - XIr. - 6

\section{PUS.}

Corpuscles of laudable pus, 670 diam. - $\quad$ - $\quad-\quad$ xrIr. - 1

The same acted on by acetic acid, 670 diam. - $\quad-$ xIII. - 2

The same treated with water, 670 diam. $\quad-\quad-\quad-x m . \quad-3$

Epithelial scales from pustule, 670 diam. $\quad$ - $\quad-\quad$ - xirr. - 4

Corpuscles from scrofulous abscess, 670 diam. - $\quad-$ xII. $\quad$ - 5

Vibrios in venereal pus, 670 diam. $\quad$ - $\quad-\quad-\quad$ xIIr. $\quad-6$ 


\section{MILK.}

Globules of healthy milk of woman, 670 diam.

The same of impoverished human milk, 670 diam.

- Plate xiv. Fig. 1

Colostrum, 670 diam.

Ditto, with several corpuscles, 670 diam.

Globules of large size, 670 diam.

Ditto, aggregated into masses, 670 diam.

Pus in the milk of woman, 670 diam. -

Blood corpuseles in human milk, 670 diam. -

Globules after treatment by ether, 670 diam.

- - xiv. - 2

The same after the application of acetic acid, 670 diam. - xv. -4

Caseine globules, 670 diam. - - - - - - - xv. - 5

Milk of cow adulterated with flour, 670 diam. $\quad-\quad$ xv. $\quad-6$

\section{SEMEN.}

Spermatozoa and spermatophori of man, 900 diam. - - xvi. - 1

Spermatozoa of Certhia familiaris - $\quad-\quad-x v 1 . \quad 2$

FAT.

The fat vesicles of a child, 130 diam. $\quad-\quad-\quad$ xvir. $\quad-1$

Ditto of an adult, 130 diam. $\quad$ - $\quad$ - $\quad$ - Xvirr. - 2

Ditto of the pig, with apparent nucleus, 130 diam. - _ xIx. - 1

Ditto of the same, ruptured, 130 diam. - $\quad$ - $\quad$ xIx. - 2

Ditto of marrow of the femur of a child, 130 diam. - - xIx. - 3

Ditto, with the membranes of the vesicles ruptured,

130 diam. -

- xix. -4

Crystals on human fat vesicles, 130 - $\quad$ - $\quad$ - xix. - 5

Fat vesicles in melicerous tumour, $130 \mathrm{diam}$. - - XIx. - 6

Ditto contained in parent cells, 120 diam. - - - LXIx. $\quad-10$

Ditto after the absorption of the parent cell-membrane,

120 diam. -

- - exIx. -11

\section{EPITHELIUM.}

Buccal epithelial cells, 670 diam.

Cuneiform ditto from duodenum, 670 diam. - $\quad-\quad$ - xx. $\quad-2$

Ciliary epithelium from trachea of frog, 670 diam. - - xxı. - 1

Human ciliary epithelium from lung, 670 diam. - - - XxI. - 2

Ditto from trachea, 670 diam. - _ - - - XxI. - 3

Tesselated epithelium from tongue of frog, 670 diam. - xxI. - 4

Ditto from tongue of triton, $670 \mathrm{diam}$. - - $\quad-\quad$ xxr. $\quad-5$

Ditto from serous coat of liver, 670 diam. - - - - xxIr. - 1

Ditto from choroid plexus, 670 diam. $\quad$ - $\quad$ - $\quad$ - xxrr. - 2

Ditto from vena cava inferior, 670 diam. $\quad$ - $\quad-\quad$ xxIr. $\quad-3$ 
Ditto from arch of the aorta, 670 diam. - - Plate xxIr. Fig. 4

Ditto from surface of the uterus, 670 diam. - _ - xxı. - 5

Ditto from the internal surface of the pericardium,

670 diam. - - - - - - - -

Ditto of lateral ventricles of brain, 670 diam. $\quad-\quad$ xxvi. $\quad-6 \mathrm{E}$

Ditto of mouth of menobranchus lateralis, 670 diam. - xxvr. $-6 \mathbf{D}$

\section{EPIDERMIS.}

Upper surface of epidermis, 130 diam. $\quad$ - $\quad-\quad$ - xxmI. $\quad$ - 1

Under surface of ditto, 130 diam. - $\quad-\quad$ - $\quad-$ xxur. $\quad-2$

Epidermis of palm, viewed with a lens only - $\quad-\quad$ - xxrv. $\quad-1$

Ditto, magnified 100 diam. - $\quad$ - $\quad$ - $\quad-\quad$ - xxrv. $\quad$ - 2

Vertical section of ditto, 100 diam. - $\quad-\quad$ - $\quad$ - xxIv. - 3

Ditto of one of the ridges, 100 diam. $\quad-\quad-\quad$ xxrv. -4

Epidermis from back of hand, viewed with a lens - - xxrv. - 5

A portion of same more highly magnified, 100 diam. - xxrv. - 6

Epidermis from back of hand, 100 diam. - - - xxvr. - 1

Ditto, viewed on its under surface, 100 diam. $\quad$ - - $\quad$ xxvr. $\quad-2$

Portion of ditto, with insertion of hairs, 100 diam. - - xxvr. - 3

Ditto from back of neck, 670 diam. - _ _ - - Xxvr. - 5

Detached cells of epidermis, 670 diam. $\quad-\quad-\quad-\mathrm{xxvI.}-6 \mathrm{~A}$.

Cells of vernix caseosa, 130 diam. - - - - - xxvi. -6 в.

Cells of ditto, 670 diam. - $\quad$ - $\quad-\quad-\quad-x x v r .6$ c.

\section{NAILS.}

Longitudinal section of nail, 130 diam. $\quad-\quad \ldots \quad-\quad$ xxv. $\quad-1$

Ditto, showing unusual direction of striæ, 130 diam. - $-\mathrm{xxv}$. -2

Ditto, with different distribution of strix, 130 diam. - - xxv. - 3

Transverse section of nail, 130 diam. $\quad-\quad-\quad-\quad x x v . \quad-4$

Cells of which the layers are formed, 130 diam. and

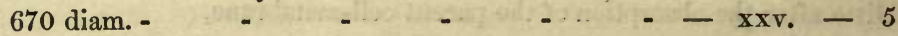

Union of nail with true skin, 100 diam. $\quad-\quad-\quad-$ xxvr. $\quad-4$

\section{PIGMENT CELLS.}

Cells of pigmentum nigrum (human), 760 diam. - - xxvir. - 1

Ditto of the same of the eye of a pig, 350 diam. - - xxvir. -2

Stellate cells of lamina fusca, 100 diam. $\quad$ - _ - - exvir. $\quad$ - 3

Ditto more highly magnified, 350 diam. - $\quad-\quad-$ xxvir. $-4 \mathrm{~A}$

Cells of skin of negro, $670 \mathrm{diam}$. - - - - - $\quad$ - $x x v r I . \quad-4$ в

Ditto from lung, 670 diam. - $\quad$ - $\quad$ - $\quad$ - $\quad$ - xxvir. $\quad-4 \mathrm{c}$

Cells in epidermis of negro, $350 \mathrm{diam} . \quad-\quad-\quad-\mathrm{xxvII}^{-} \quad-5$

Ditto in areola of nipple, 350 diam. - $\quad-\quad-\quad-x x v r r . \quad-6$

Ditto of bulb of hair, 670 diam. $\quad$ - $\quad$ - $\quad-$ xxvirr. $\quad$ - 5 


\section{HAIR.}

Bulb of hair, 130 diam. - _ _ _ _ _ n - Plate xxvin. Fig. 1

Root of a grey hair, 130 diam. $\quad$ - $\quad$ - $\quad$ - $\quad$ - xxviI. $\quad$ - 2

Cells of outer sheath, 670 diam. - _ - $\quad$ - - $\quad$ xxvm1. - 3

Portion of inner sheath, 350 diam. - _ - $\quad$ - $\quad$ - xxvir. - 4

Stem of grey hair of scalp, 350 diam. $\quad-\quad-\quad-\quad$ xxix. $\quad-1$

Transverse section of hair of beard, 130 diam. $\quad-\quad-\quad$ xxix. $\quad 2$

Another section of the same, 130 diam. - _ - $\quad-\quad$ xxix. - 3

Fibres of the stem of the hair, 670 diam. - _ - _ xxix. - 4

Apex of hair of perineum, 350 diam. - $\quad-\quad-\quad$ xxıx. $\quad 5$

Ditto of scalp, terminating in fibres, 350 diam. - _ $\quad$ xxıx. - 6

Ditto of same with needle-like extremity, 350 diam. $-\mathbf{x x I x}$ - 7

Root of hair of scalp, 130 diam. - - - $\quad-\quad$ xxIx. $\quad 8$

Another form of same, 130 diam. - _ _ - $\quad$ - xxix. - 9

Hair with two medullary canals, 130 diam. $\quad-\quad-\quad \mathbf{x x I x}$ - 10

Insertion of hairs in follicles, 100 diam. - $\quad-\quad-\quad x x v 1 . \quad-3$

Disposition of hairs on back of hand _ - $\quad-\quad$ xxiv. $\quad 5$

\section{CARTILAGE.}

Transverse section of cartilage of rib, 350 diam. - $-\mathbf{x x x}-1$

Parent cells seen in section of ditto, 350 diam. $\quad-\quad-\quad \mathbf{x x x}$ - 2

Vertical section of articular cartilage, 130 diam. - - $\quad \mathbf{x x x}$ - 3

Ditto of intervertebral cartilage, 80 diam. - _ - $\quad$ - $\mathbf{x x x}$. $\quad 4$

Cartilage of concha of ear, 350 diam. $\quad-\quad-\quad-\quad x x x I-1$

Cells of intervertebral cartilage, 350 diam. $\quad-\quad-\quad \mathbf{x x x I} . \quad-2$

Section of cartilage and bone of rib, 130 diam. - - xxxI. -3

Ditto of one of the rings of the trachea, 350 diam. - $-\quad \mathbf{x x x}_{\text {. }}-4$

Ditto of thyroid cartilage with fibres, 130 diam. - - xxxI. -5

Cartilage of ossification, 100 diam. - $\quad-\quad-\quad-x x x r v$ - 1

Section of primary cancelli, 350 diam. $\quad-\quad \quad-\quad-x x x ı$ - $\quad-2$

Ditto of same, more advanced, 350 diam. - _ - - xxxiv. - 3

Cartilage of ossification, 350 diam. - $\quad$ - $\quad$ - - xxxıv. - 4

Section of cartilaginous epiphysis, 30 diam.- $\quad$ - $\quad-\quad \mathbf{x x x}$ - 1

Ditto of same, with bone, 30 diam. $\quad-\quad-\quad-\quad x x x v$ - 2

Ditto of same, more highly magnified, 330 diam. - - xxxv. -3

Section of cartilage and bone of rib, 130 diam. $\quad-\quad-\quad \mathbf{x x v}$. 6

\section{BONE.}

Transverse section of ulna, 60 diam. $\quad-\quad+\quad-\quad$ xxxir. $\quad-1$

Cross section of Haversian canals, 220 diam. $\quad-\quad-\quad$ xxxir. -2

Ditto of same more highly magnified, 670 diam. - $-\mathbf{x x x ı . ~ - ~} 3$

Longitudinal section of long bone, 40 diam. $\quad-\quad-$ xxxII. $\quad 4$

Parietal bone of feetus, 30 diam. - - - - - xxxir. - 1

Portion of same more highly magnified, 60 diam. - $-\mathbf{x x x I I . ~}-2$. 
Spiculæ of bone of fotal humerus, 350 diam. - Plate xxxirr. Fig. 3

Lamina of a long bone, 500 diam. - - xxxiIr. -4

Cancelli of long bone of foetus, 350 diam. - - - $\quad$ xxxır1. $\quad-5$

Section of femur of pigeon fed on madder, 220 diam. - xxxiIr. -6

Section of epiphysis and shaft of foetal femur, 100 diam. - xxxiv -1

Transverse section of primary cancelli, 350 diam. - xxxiv. - 2

Section of cancelli more advanced, $350 \mathrm{diam} . \quad-\quad-\mathrm{xxxrv} . \quad-3$

Ditto of epiphysis and shaft of fœetal femur, 350 diam. - xxxrv. - 4

Ditto of cartilaginous epiphysis of humerus, 30 diam. - xxxv. - 1

Ditto of same with bone, 30 diam. - _ - - $\quad$ - xxxv. $\quad-2$

The same more highly magnified, 330 diam. - - $\quad$ xxxv. $\quad 3$

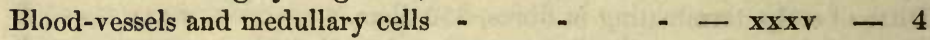

Section of shaft of fotal long bone, 20 diam. - - xxxv. - 5

Ditto of bone and cartilage of rib, 130 diam. $\quad-\quad$ xxxv. -6

\section{TEETH.}

Vertical section of insisor tooth, seen with lens - - xxxv1. - 1

Tubes of dentine near their termination, $670 \mathrm{diam}$. - xxxvI. -2

A not unfrequent condition of same, 670 diam. - - xxxvı. - 3

Tubes of dentine near their commencement, 670 diam. - xxxvI. -4

Oblique section of tubes of dentine, 670 diam. - - $\mathbf{x}$ xxvı. - 5

Transverse section of ditto, 670 diam. - - - xxxvr. - 6

Transition of tubes into bone cells, 670 diam. - - xxxvr. - 7

Dilatation of ditto into bone cells, 670 diam. - $\quad$ - xxxvi. -8

Section of cementum, 670 diam. - - - - - xxxvrr. - 1

Ditto of same traversed by tubes, 670 diam. - $\quad$ - xxxvir. $\quad-2$

Ditto of same showing angular cells, 670 diam. - - xxxvir. -- 3

Fungus on section of dentine, 670 diam. - $\quad-\quad$ - xxxvır. $\quad 4$

Oil-like globules on section of same, $350 \mathrm{diam} . \quad-\quad$ xxxvir. -5

Section of secondary dentine, 350 diam. - $\quad-\quad$ - xxxvir. $\quad-6$

Ditto of bicuspid tooth, seen with lens only $\quad-\quad$ xxxvir. -7

Vertical section of enamel, 220 diam. - - - - xxxix. - 3

Enamel cells, seen lengthways, 670 diam. - - - - xxxix. - 4

Cross section of cells of enamel, 670 diam. - $\quad-$ xxxix. - 5

\section{FIBROUS TISSUE.}

Longitudinal section of tendon, $670 \mathrm{diam}$. - $\quad-\quad$ xxxix. $\quad-1$

Transverse section of same, 670 diam. - - - - xxxrx. - 2

White fibrous tissue, 670 diam. - $\quad-\quad-$ xxxIx. $\quad-6$

Mixed ditto, 670 diam. $\quad-\quad-\quad-\quad-\quad-x x x r x . \quad-7$

Yellow fibrous tissue, 670 diam. - $\quad-\quad-\quad-\quad x x . \quad-1$

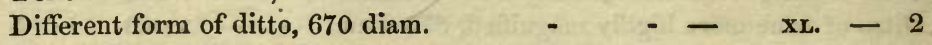

Development of blood-vessels, 350 diam. - - - - $\quad$ xL. -3

Areolar form of mixed fibrous tissue, 330 diam. - - xx. -4

-Blood-vessels of pia mater, 350 diam. - $\quad$ - $\quad$ - xu. $\quad-5$ 
Development of white fibrous tissue, 670 diam.

Portion of dartos, 670 diam.

Section of corpora cavernosa, slightly magnified
- Plate Xurrr. Fig. 2

- X xirr. - 3

- xuIr. - 4

\section{MUSCLE.}

Portion of striped muscle, 60 diam - - - - - - xLr. - 1

Fragment of unstriped ditto, 670 diam. $\quad-\quad-\quad$ - xLr. $\quad-2$

Muscular fibrillæ of the heart, 670 diam. - - - xur. - 3

Fragment of striped muscle of frog, 350 diam. _ - - xul. -4

Fibres and fibrillæ of voluntary muscle, 350 diam. - - xLII. - 1

Fibres acted on by acetic acid, 350 diam. . . - - xurr. - 2

Ditto in different degrees of contraction, 350 diam. - - xuIr. - 3

Union of muscle with tendon, 130 diam. - - - - xur. - 4

Transverse section of muscular fibres, 350 diam. - - xuIr. - 5

Fibres of voluntary muscle of fotus, 670 diam. - - x LIII. - 1

Zigzag disposition of fibres, 350 diam. $\quad-\quad$ - $\quad$ xLIII. - 5

Striped muscular fibre and fibrillæ, 670 diam. $\quad-$ xumI. $\quad-6$

\section{NERVES.}

Tubes of motor nerve, 670 diam. - $\quad$ - $\quad$ - $\quad$ - - xulv. - 1

The same after the action of spirit, 670 diam. - - - xurv. - 2

The same after the action of acetic acid, 670 diam. - - xurv. - 3

Portion of Casserian ganglion, 350 diam. - - - - xuIv. - 4

Nerve tubes of cerebellum, $670 \mathrm{diam}$. $\quad$ - $\quad$ - $\quad$ - xurv. - 5

Ditto of cerebrum, with clear cells, 670 diam. - - - xurv. $\quad-6$

Varicose condition of ditto, 670 diam. - - - - xurv. - 7

Filaments of great sympathetic, 670 diam. - - - - xLv. - 1

Cells of grey matter of cerebellum, 670 diam. $\quad$ - $\quad$ xuv. $\quad-2$

Ditto of same, inner stratum, 670 diam. - _ - - xLv. - 3

Caudate ganglionary cells, $350 \mathrm{diam}$. $\quad$ - $\quad$ - $\quad$ xLv. $\quad$ - 4

(Spinal cord, Medulla oblongata, Cerebellum.)

Ditto from locus niger of crus cerebelli, 350 diam. - - xuv. - 5

Ditto from hippocampus major, 350 diam. - - - - xLv. - 6

Ditto from locus niger of crus cerebri, 350 diam. - - xLv. - 7

Pacinian bodies, natural size $\quad$ - $\quad$ - $\quad$ - $\quad$ - xuvr. $\quad$ - 1

Ditto, magnified 60 diam. - $\quad$ - $\quad$ - $\quad$ - $\quad$ - xLvi. $\quad$ - 2

A single Pacinian body, 100 diam. - $\quad$ - $\quad$ - $\quad$ xuvi. - 3

An ancmalous Pacinian body - $\quad$ - $\quad$ - xLvi. - 4

Two other anomalous Pacinian bodies - - - XLvi. - 5

Cells from corpus dentatum of cerebellum, 350 diam. - xLvi. $\quad-6$ 


\section{LUNG.}

Pleural surface of lung, 30 diam. - - - - Plate xuvII. Fig. 1

Ditto, with vessels of first order, 30 diam. - $\quad-\quad$ xLvIr. $\quad-2$

Ditto, magnified 100 diam. - - - - xLvir. - 3

Section of lung injected with tallow, 100 diam. - - xLvır. - 1

Casts of air-cells, 350 diam. $\quad$ - $\quad$ - $\quad$ - $\quad$ - xuvirr. - 2

Section of lung injected with size, 100 diam. - - xuvir. - 3

Pleural surface of lung, with vessels of second

order, 100 diam. $\quad$ - $\quad-\quad$ - $\quad-\quad$ - xLIx. $\quad$ - 1

Section of lung, with air-cells uninjected, 100 diam. - xLIx. -2

Capillaries of lung, 100 diam. $\quad-\quad$ - $\quad$ - xurx. - 3

GLANDS.

Follicles of stomach, with epithelium, 100 diam. - - $\quad$.. - 1

Ditto of large intestine, in similar condition, 100 diam. - $\quad$ L. - 2

Ditto of same, without epithelium, 60 diam. - - $\quad$ L. -- 6

Termination of follicles of large intestine, 60 diam. - - $\quad$ L. -7

Follicles of Lieburkuhn in duodenum, 60 diam. - - LII. - 5

Vessels of ditto of appendix vermiformis, 100 diam. - LI. - 1

Ditto of same of stomach of cat, 100 dian. - _ - $\quad$ LI. - 2

Stomach tubes, cross section of, 100 diam - $\quad-\quad$ L. -3

Longitudinal view of stomach tubes, 220 diam. - - L. - 4

Ditto of the same, 100 diam. $\quad$ - $\quad$ - $\quad$ - $\quad$ L. $\quad$ - 5

Villi of small intestine, with epithelium, 100 diam. - LII. - 1

Ditto, without epithelium, showing lacteals, 100 diam. - LII. - 2

Vessels of villi in duodenum, 60 diam. - - - u. - 3

Ditto of same in jejunum, 60 diam. - $\quad-\quad-\quad$ u. -4

Ditto of same of foal, 60 diam. - $\quad$ - $\quad$ - $\quad$ LI. $\quad-5$

Solitary glands of small intestine, natural size - - LXII. - 6

Ditto of large intestine, slightly magnified $\quad-\quad$ - $\quad$ u. $\quad-6$

Aggregated or Peyer's glands, 20 diam. - - - - LII. - 3

Side view of same, 20 diam. _ _ _ _ - _

Sebaceous glands in connection with hair, 33 diam. - - LIr. - 3

Ditto from caruncula lachrymalis - $\quad$ - $\quad$ - $\quad$ uII. $\quad-1$

An entire Meibomian gland, 27 diam. - $\quad$ - $\quad$ - urI. - 2

Illustrations of Mucous glands, $45 \mathrm{diam} . \quad-\quad-\quad$ - LIIr. - 4

Parotid gland of embryo of sheep, 8 diam. - _ - L LIv. - 1

Ditto of human subject, further developed, 40 diam. - urv. - 2

Mammary gland, portion of, slightly magnified - - LIV. - 5

Ditto of same, with milk globules, 90 diam. _ - L LIv. - 3

Ditto of same, more highly magnified, $198 \mathrm{diam}$. - L LV. - 6

Liver, section of, showing the lobules, 35 diam. - - Lrv. - 4

Surface of ditto, showing the intra-lobular veins, 15 diam.

Section of liver showing the hepatic venous plexus, 20 diam. -

- $\quad$ -

Lv. - 2 
Vessels of portal system, 20 diam.

- Plate Lv. Fig. 3

Section of liver, showing interlobular vessels, 24 diam. - Lv. - 4

Surface of liver, showing portal capillary system, 20 diam.

Ditto, showing both hepatic and portal venous systems, 20 diam.

- LV. - 5

Ditto, with both systems completely injected, 20 diam. - LVI. - 4

Ditto, with portal vein and hepatic artery, 18 diam. - _ LVI. - 2

A terminal biliary duct, 378 diam. - _ - _ - Lvir. - 1

Secreting cells of liver in healthy state, 378 diam. - - Lvir. - 2 A

Ditto, gorged with bile, 378 diam. - _ - _ - Lvir. -2 в

Ditto, containing oil globules, 378 diam. - _ - _ LVI. - 2 c

Prostate gland, calculi of, 45 diam. - _ - - - Lvir. - 3

New tubular gland in axilla, 54 diam. _ _ _ - LVIr. 4 A

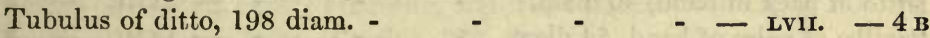

Ceruminous glands, portions of, 45 diam. - $\quad-\quad$ LVII. $\quad 5$

Sudoriferous gland, tubulus of, 198 diam. - _ - _ LVIr. - 4 c

Kidney, tubes of, with epithelium, 99 diam. - _ - _ Lvir. - 1

Cross section of elastic framework, 99 diam. - _ - Lvil. - 2

Ditto of framework and tubes, 99 diam. - _ _ - Lvir. - 3

Section of vessels in tubular part of kidney, 33 diam. - Lvir. - 4

The same vessels seen lengthways, 33 diam. - _ - Lvir. $\quad 5$

Tubes with epithelium, 378 diam. - - - - - Lvir. - 6

Corpora Malpighiana of kidney, injected, 40 diam. - - LxIx. - 1

Uriniferous tubes of a bird, 40 diam. _ - _ - L1x. - 2

Corpora Malpighiana of the horse, 40 diam. - _ _ _ L1x. - 3

Intertubular vessels of surface of kidney, 90 diam. - - LIx. - 4

Transverse section of injected kidney, 67 dian. $\quad-\quad-\quad$ IX. $\quad 5$

Uninjected corpora Malpighiana - _ - _ - - Lx. - 2

With capsule, 100 diam. $\quad$ - $\quad$ - $\quad$ - $\quad$ - $\quad$ -

Without ditto, 100 diam. $\quad$ - $\quad$ - $\quad$ - $\quad-\quad-\quad-$ B

Malpighian body, more highly magnified, 125 diam. - LX. -3 A

Afferent and efferent vesscls of Malpighian tuft, 45 diam. - LX. -3 B

Epithelial cells of the tubes, 378 diam. - $\quad-\quad-\quad \mathbf{L X}-3 \mathbf{C}$

Testis, tubes of, 27 diam. - _ - _ _ _ - _ Lx. - 1

'Tubes of ditto, more highly magnified, 99 diam. - - Lx. - 4

Vessels of thyroid gland, injected, 18 diam. - _ - LXI. - 1

Vesicles of ditto, viewed with a lens only - _ - _ LXI. - 2

Ditto of same, magnified 40 diam. - _ _ - LXI. - 3

Ditto of same, showing the structure of their walls,

67 diam. - $\quad$ - $\quad$ - $\quad$ - $\quad$ - $\quad$ - $\quad$ - LXI. $\quad 4$

Lobes and vesicles of same in their ordinary condition,

Nuclei of vesicles of thyroid, 378 diam. - _ - $\quad-$ LxI. -6

Follicles of thymus, with vessels, 33 diam. - _ - Lxr. - 7

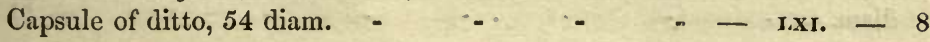


Nuclei and simple cells of same, 378 diam. -

- Plate LXI. Fig. 9

Compound or parent cells of ditto, 378 diam.

- LXI. -10

Spleen, nuclei and vessels of, 378 diam. $\quad-\quad$ - $\quad$ - LxII. - 1

Supra-renal capsule, plexus on surface of, 54 diam. - - Lxır. - 2

Tubes of ditto, 90 diam. $\quad$ - $\quad$ - $\quad$ - $\quad$ - $\quad$ - LxII. $\quad-3 a$

Nuclei, parent cells, and molecules of ditto, 378 diam. - LxIr. - $3 b$

Vessels of supra-renal capsule, 90 diam. - $\quad$ - $\quad$ - Lxir. - 5

Pineal gland, compound bodies of, 130 diam. $\quad-\quad$ - LXIx. - 7

Pituitary gland, cells and fibrous tissue of, 350 diam. - LxIx. -8

\section{ANATOMY OF THE SENSE OF TOUCH.}

Epidermis of palm of hand, 40 diam.

Ditto of back of hand, 40 diam. $\quad$ - $\quad$ - $\quad$ - $\quad$ - LxIII. - 2

Papillæ of palm of hand, 54 diam. - $\quad-\quad$ - $\quad-$ LxIII. $\quad$ - 3

Ditto of back of hand, 54 diam. $\quad$ - $\quad-\quad$ - $\quad$ - Lxill. $\quad-4$

Epidermis of palm, under surface of, 54 diam. - - LxIII. - 5

Ditto of back of hand, under surface of, 54 diam. - - LxIII. - 6

Vessels of papillæ of palm of hand, 54 diam. $\quad-\quad$ LxIII. $\quad-7$

Ditto of same of back of hand, 54 diam $\quad-\quad-\quad$ LxIII. $\quad-8$

\section{ANATOMY OF THE SENSE OF TASTE.}

Filiform papillæ, with long epithelial appendages,

41 diam. - - $\quad$ - $\quad$ - $\quad$ - $\quad$ - $\quad$ - $\quad$ - $\quad$ - LXIv. $\quad$ - 1

Ditto, with shorter epithelial processes, 27 diam. - - Lxrv. - 2

Ditto, without epithelium, near apex of tongue, 27 diam. - Lxiv. - 3

Ditto, without epithelium, near centre of same, 31 diam. - Lxıv. - 4

Filiform and fungiform papillæ, without epithelium,

27 diam. - $\quad$ - $\quad$ - $\quad$ - $\quad$ - $\quad$ - - LXIv. - 5

Peculiar form of compound papillæ, 27 diam. - - LxIv. - 6

Filiform papillæ in different states, 27 diam. $\quad-\quad$ LxIv. - 7

Ditto, with epithelium partially removed, 27 diam. - Lxiv. - 8

Follicles of tongue, with epithelium, 27 diam. - - Lxv. - 1

Ditto, without epithelium, 27 diam. - $\quad$ - $\quad$ - - Lxv. - 2

Ditto, viewed as an opaque object, 27 diam. - $\quad$ - _ Lxv. - 3

Filiform papillæ from point of tongue, 27 diam. - - LXv. - 4

Follicles and papillæ from side of ditto, 20 diam. - - LXv. - 5

Simple papillæ, with epithelium, 45 diam. - - - - Lxv. - 6

Filiform papillæ, with ditto, 18 diam. $\quad-\quad$ - $\quad$ LXv. $\quad-7$

The same, viewed with a lens only - - - - - Lxv. - 8

Side view of certain compound papillæ, 20 diam. - - Lxv. - 9

Simple papilla from under surface of tongue, 54 diam. - Lxv. -10

Compound and simple ditto from side of tongue, 23 diam.

- Lxv. -11 
A ealiciform papilla, uninjected, 16 diam.

- Plate Lxvi. Fig. 1

Ditto, with the vessels injected, 16 diam.

- LXXi. - 2

Filiform papillæ near centre of tongue, injected, 27 diam.

Simple papillæ, injected, 27 diam. - $\quad-{ }_{-}-\frac{-}{2}$

Fungiform ditto, injected, 27 diam. - $\quad$ - $\quad$ - LXvI. - 6

\section{ANATOMY OF THE GLOBE OF THE EYE.}

Vertical section of cornea, 54 diam. -

A portion of retina, injected, $90 \mathrm{diam} . \quad-\quad \quad-\quad$ Lxvir. $\quad-\quad 2$

Section of schlerotic and cornea, 54 diam. - - - Lxvir. - 3

Vessels of choroid, ciliary processes, and iris, 14 diam. - Lxvir. - 4

Nuclei of granular layer of retina, 378 diam. - - LXvir. - 5

Cells of the same, 378 diam. - - - - - Lxvir. - 6

Ditto of vesicular layer of retina, 378 diam. $\quad-\quad$ LxVII. $\quad-7$

Caudate cells of retina, 378 - $\quad$ - $\quad-\quad$ - $\quad$ - LXvir. $\quad$ - 8

Cells of the membrana Jacobi, 378 diam. - $\quad$ - $\quad$ - LxvII. - 9

Fibres of the crystalline lens; $a, 198$ diam.; $b, 378$ diam. - LXvr. -10

A condition of the posterior elastic lamina, 78 diam. - Lxvir. - 11

Peculiar markings on same, 78 diam. - - - Lxvir. - 12

Crystalline lens of sheep, slightly magnified - - Lxvir. - 13

Fibres of lens near its centre, 198 diam. - - - - Lxvir. - 14

Stellate pigment in eye of sheep, slightly magnified - - Lxvir. - 1

Venæ vorticosæ of eye of sheep, injected - - - Lxvir. - 2

Conjunctival epithelium, oblique view of, 378 diam. - Lxvır. - 3

Ditto, front view of, $378 \mathrm{diam}$. $\quad$ - $\quad$ - $\quad-\quad$ - Lxvir. $\quad$ - 5

Ciliary muscle, fibres of, 198 diam. - - - - - Lxvirr. - 4

Gelatinous nerve fibres of retina, 378 diam. $\quad-\quad$ - Lxviı. $\quad-6$

Cellated structure of vitreous body, 70 diam. - - Lxvir. - 7

Fibres on posterior elastic lamina, 70 diam. $\quad-\quad$ - Lxvir. $\quad-8$

Portion of the iris, 70 diam. $\quad-\quad$ - $\quad-\quad$ - Lxvirr. $\quad-9$

Epithelium of crystalline lens, 198 diam. - - - - IXvirr. - 10

Ditto of the aqueous humour, 198 diam. - - - LXvirr. - 11

Hexagonal pigment of the choroid, 378 diam. - - Lxvir. - 12

Stellate pigment of same, $378 \mathrm{diam}$. $\quad$ - $\quad$ - $\quad$ - LxvirI. $\quad-13$

Irregular pigment of uvea, 378 diam. $\quad-\quad$ - LXvIr. $\quad-14$

\section{ANATOMY OF THE NOSE.}

Mucous membrane of true nasal region, 80 diam. - - LxIx. - 1

Ditto of pitutiary region, injected, $80 \mathrm{diam}$. - - LxIx. - 2

Capillaries of olfactory region of human foetus, 100 diam.

- LxIx. -12 


\section{ANATOMY OF THE EAR.}

Denticulate laminæ of the osseous zone, 100 diam. - Plate Lxıx. Fig. 3 Tympanic surface of lamina spiralis, 300 diam. $\quad$ - _ Lxix. - 4 Inner view of cochlearis muscle of sheep $\quad-\quad$ Lxix. - 5 Plexiform arrangement of cochlear nerves in ditto,

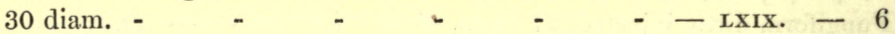

\section{VILLI.}

Villi of fœetal placenta, injected, 54 diam. - - - - Lxı. - 4 Ditto of choroid plexus, 45 diam. - $\quad$ - $\quad-\quad$ Lxix. $\quad 9$

Plates VIII., XVII., and XXXVIII., have been entirely omitted, in order to make room for more important matter. Plate VIII. was to have illustrated the solid constituents of the chyle : of these the principal are the granular corpuscles so often figured in this work; an entire plate was therefore scarcely necessary to illustrate this subject. Plate XVII. was to have exhibited the comparative anatomy of the spermatozoa: this plate also could be well dispensed with. Lastly, Plate XXXVIII. was to have shown the development of the dentinal tissues: this, although the most requisite of the three plates, could also be omitted without injury to the work. 


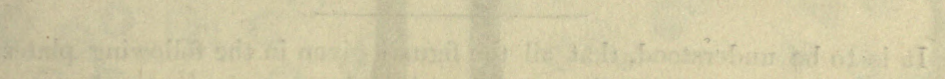

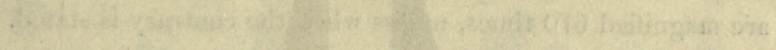

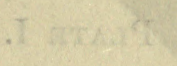

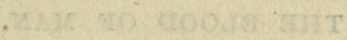

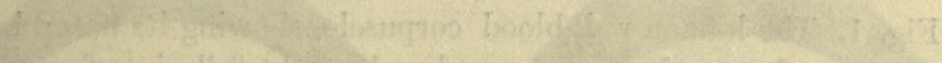

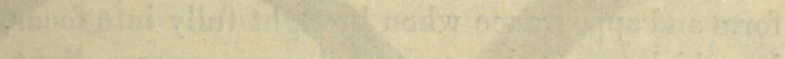

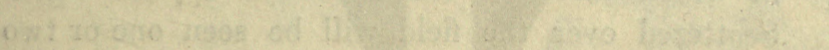

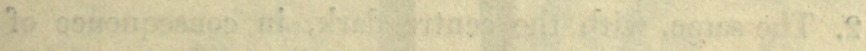

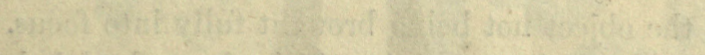

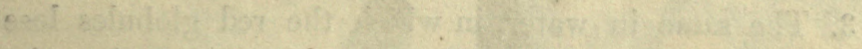

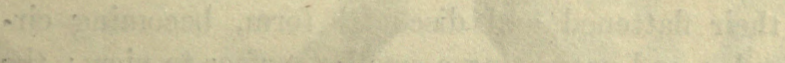

a.

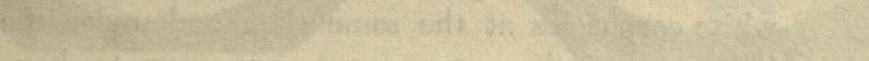

C)

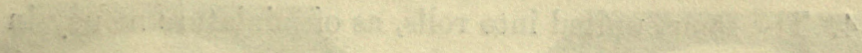

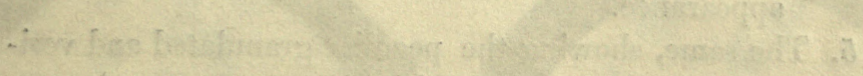

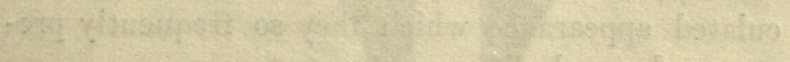

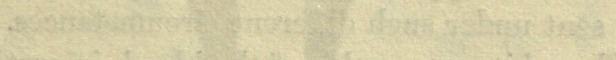

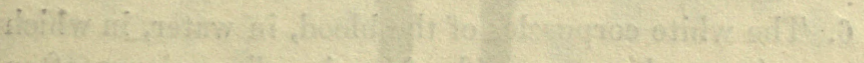

c.

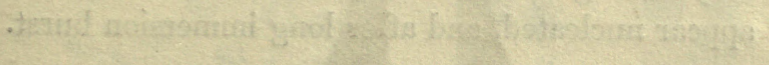




\section{EXPLANATION OF THE PLATES.}

It is to be understood, that all the figures given in the following plates are magnified 670 times, unless when the contrary is stated.

\section{Plate I.}

TIE BLOOD OF MAN.

Fig. 1. The human red blood corpuscle, showing its natural form and appearance when brought fully into focus, in which case the centre always appears light. Scattered over the field will be seen one or two white corpuscles.

2. The same, with the centre dark, in consequence of the object not being brought fully into focus.

3. The same in water, in which the red globules lose their flattened and discoidal form, becoming circular, and presenting a smaller surface to view; the white corpuscles at the same time, and under the influence of the same agent, are seen to have increased considerably in size.

4. The same, united into rolls, as of miniature money in appearance.

5. The same, showing the peculiar granulated and vesiculated appearance which they so frequently present under such different circumstances.

6. The white corpuscles of the blood, in water, in which they enlarge considerably in dimensions, often appear nucleated, and after long immersion burst. 

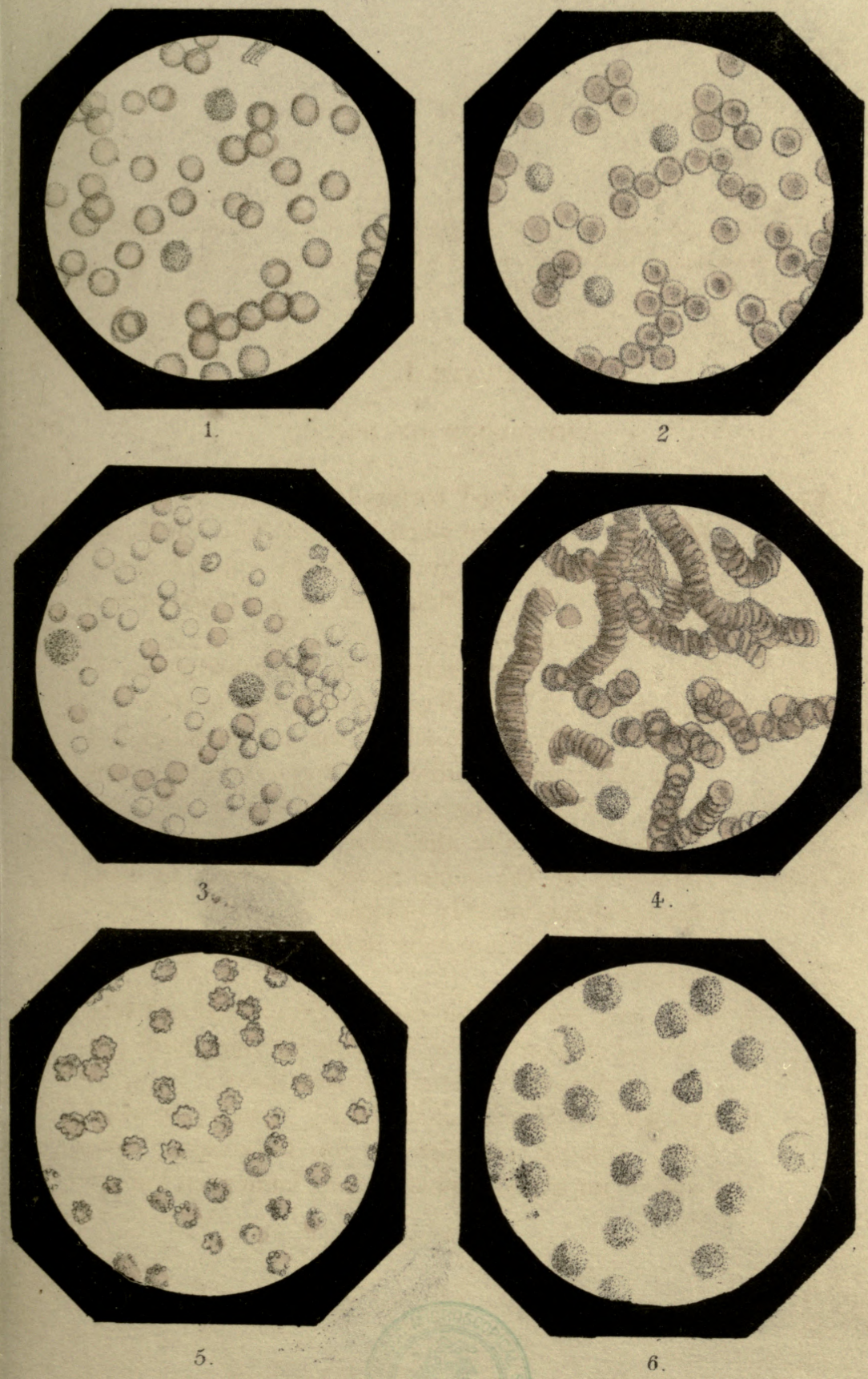



\section{1.}

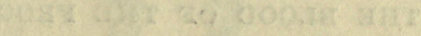

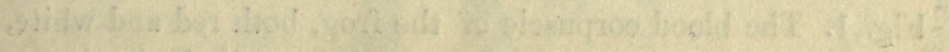

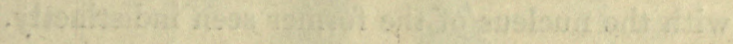

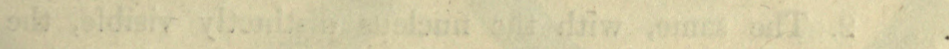

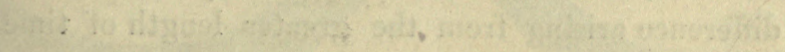

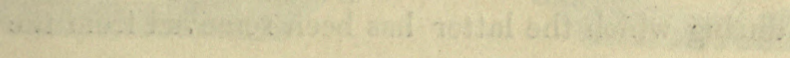

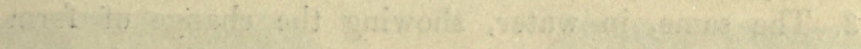

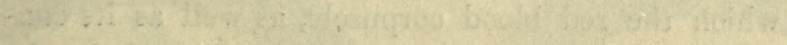

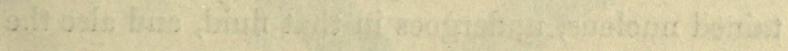

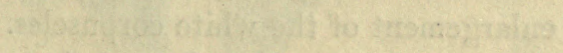

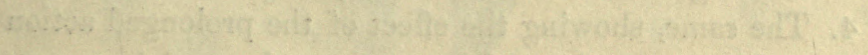

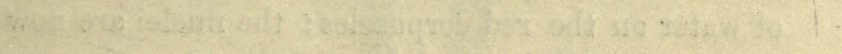

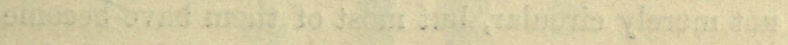

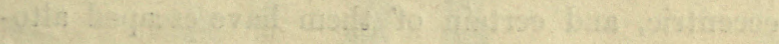

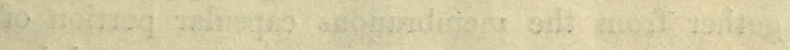
2. C.

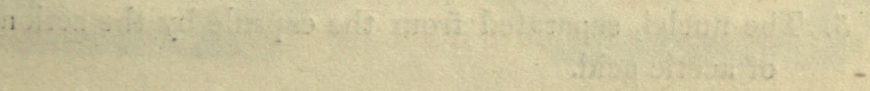

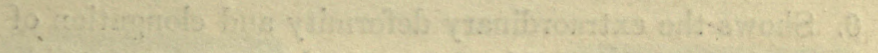

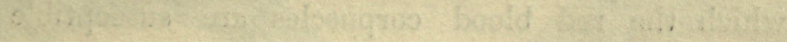
C.

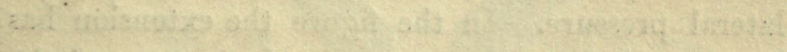

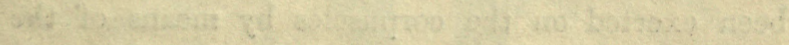

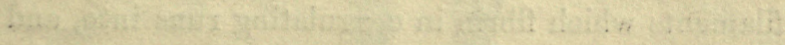
a.

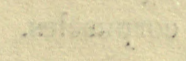




\section{Plate II.}

THE BLOOD OF THE FROG.

Fig. 1. The blood corpuscle of the frog, both red and white, with the nucleus of the former seen indistinctly.

2. The same, with the nucleus distinctly visible, the difference arising from the greater length of time during which the latter has been removed from the system.

3. The same, in water, showing the change of form which the red blood corpuscle, as well as its contained nucleus, undergoes in that fluid, and also the enlargement of the white corpuscles.

4. The same, showing the effect of the prolonged action of water on the red corpuscles; the nuclei are now not merely circular, but most of them have become eccentric, and certain of them have escaped altogether from the membranous capsular portion of the corpuscles, which and the nuclei are seen lying side by side as distinct structures.

5. The nuclei, separated from the capsule by the action of acetic acid.

6. Shows the extraordinary deformity and elongation of which the red blood corpuscles are susceptible when subject to any extending force, or even to lateral pressure. In the figure the extension has been exerted on the corpuscles by means of the filaments which fibrin in coagulating runs into, and a portion of one of which may be seen uniting the corpuscles. 

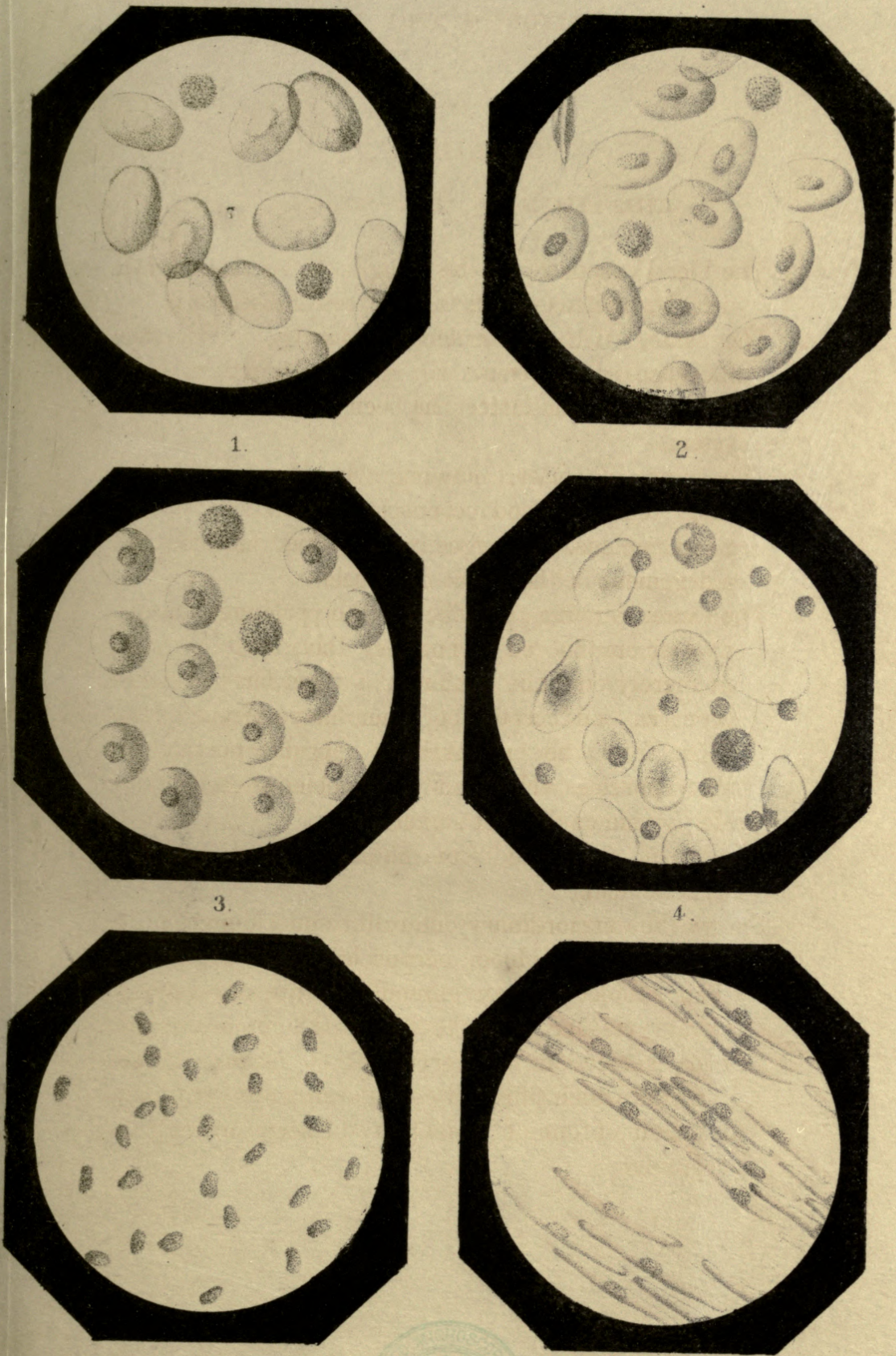

5

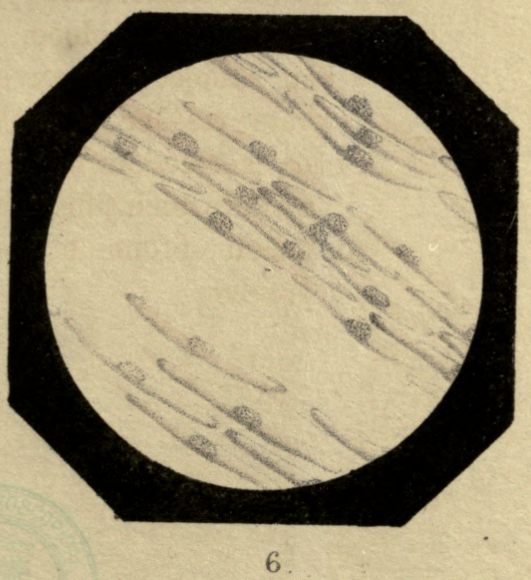





\section{1 sinate}

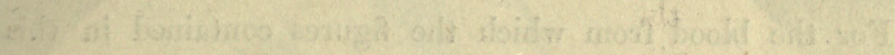

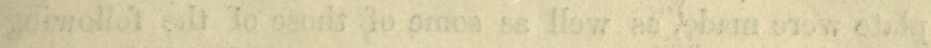

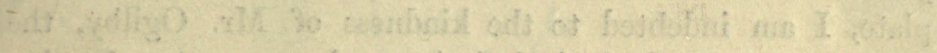

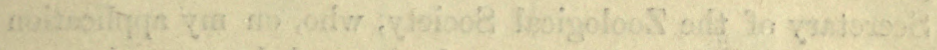

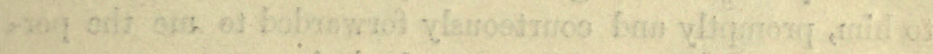

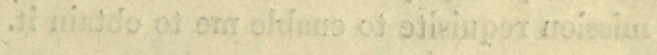

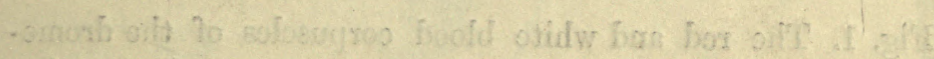

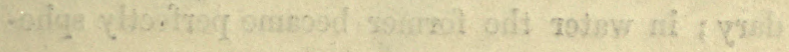

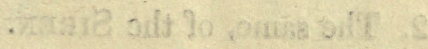

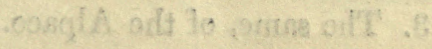




\section{Plate III.}

For the blood from which the figures contained in this plate were made, as well as some of those of the following plate, I am indebted to the kindness of $\mathrm{Mr}$. Ogilby, the Secretary of the Zoological Society, who, on my application to him, promptly and courteously forwarded to me the permission requisite to enable me to obtain it.

Fig. 1. The red and white blood corpuscles of the dromedary; in water the former became perfectly spherical.

2. The same, of the Siren.

3. The same, of the Alpaco. 
Plate III.

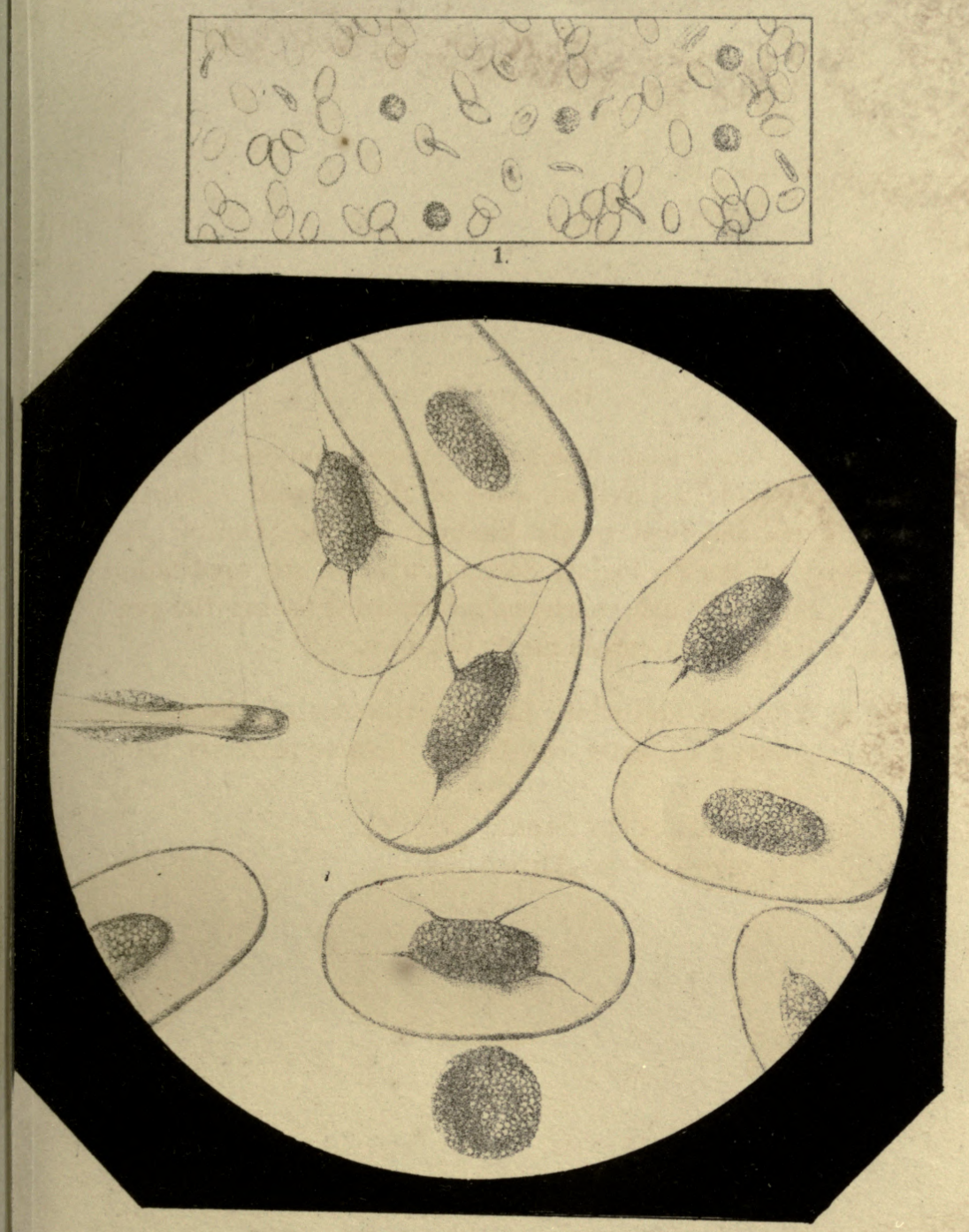

2.

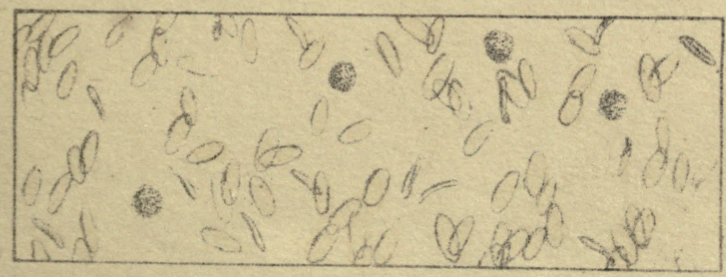





\section{Plate IV.}

Fig. 1. Represents the blood corpuscles of the elephant, red and white, which are the largest hitherto discovered amongst the mammalia.

2. Exhibits the blood corpuscles of the goat, both red and white, which are amongst the smallest as yet made known in the class to which they belong.

3. Peculiar concentric corpuscles, taken twenty-four hours after death from a polypus contained in the heart of an old man.

4. A portion of fibrin, removed from a small cavity situated beneath the buffy coating formed on some blood which had been abstracted from a woman the subject of epileptic fits, and for which she was bled; it exhibits the granular and fibrous structure, which the spontaneously coagulable element of the blood invariably assumes in solidifying

5. A portion of fibrin, constituting the buffy coat, and which formed a thick membrane on the surface of the blood abstracted from the woman already alluded to; it exhibits more clearly the fibrous construction of the fibrin, the fibres being rendered more apparent by the action of corrosive sublimate, and also some of the white corpuscles which are found usually in such abundance in the so called inflammatory crust. All false membranes have a constitution precisely similar.

6. Blood corpuscles of the earth worm in various states; those contained in the lower half of the circle reprepresent them as they appear in the liquor sanguinis, or plasma, in which most of the corpuscles speedily assume a stellate form, as do those of most of the invertebrate animals, and in which state they bear a close resemblance to the hispid pollen granules of 
the order Compositc ; the stellate form of the corpuscles is speedily followed by their considerable enlargement, rupture, and disaggregation; the corpuscles represented in the upper half of the circle have been acted upon by water, in which they quickly lose their radiate aspect, swell, increase to two or three times their original dimensions, exhibit their contained molecules more clearly, and which may frequently be seen in a state of the greatest activity; finally, the corpuscles become deformed in shape and burst. It may here be remarked, that the blood of most of the Invertebrata is colourless, arising from the fact of their blood containing but one form of corpuscle, the colourless blood corpuscle. In the Annelida, indeed, the blood is red; the colouring matter, however, is not contained in the corpuscle, but in the plasma. 


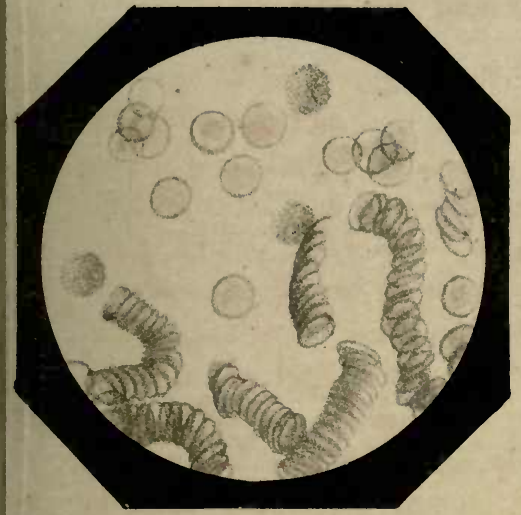

1.

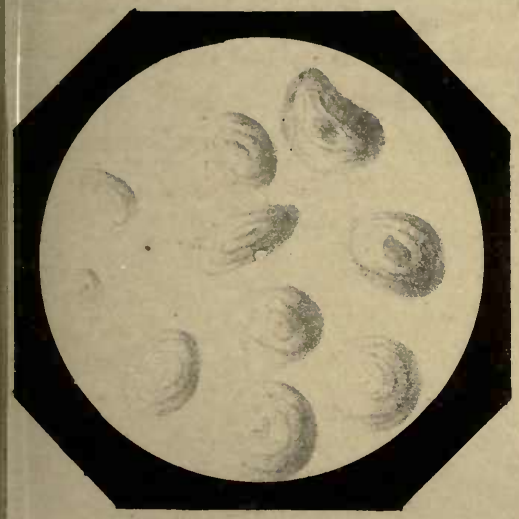

3.

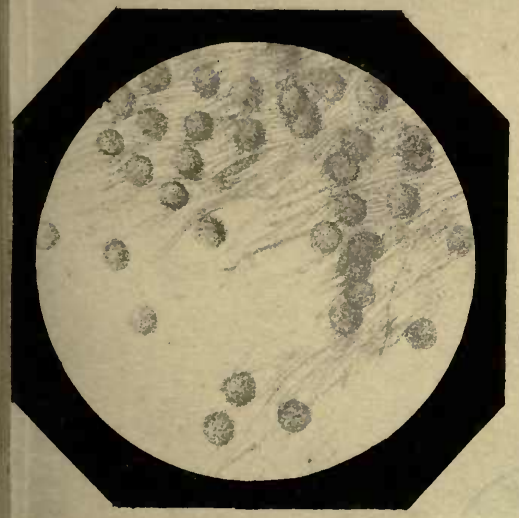

5.
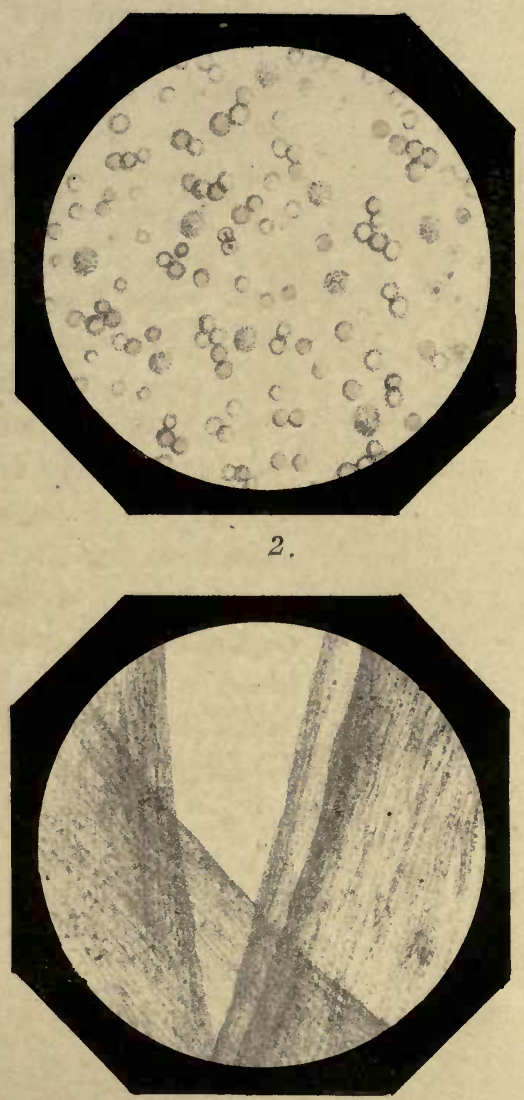

4.

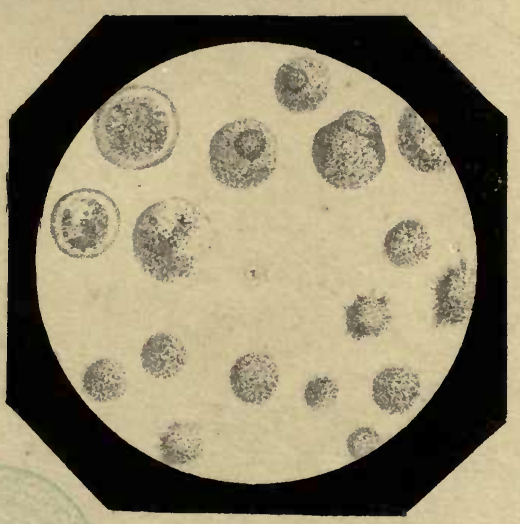





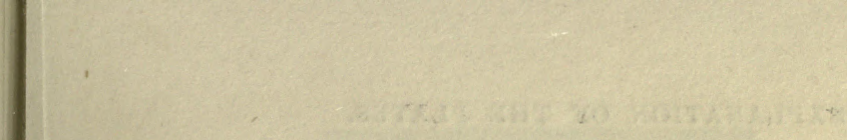




\section{Plate V.}

Fig. 1. Exhibits the eirculation in a portion of the tongue of the frog, the larger vessel is seen to be accompanied by a nerve, as is usually the case, and in all the vessels are shown the red and white blood corpuscles, with their differences of form, size, structure, colour, and position; the general direction and appearance of the muscular fibres, are likewise indicated. This figure is magnified 350 diameters.

2. Represents the distribution of the smallest capillaries in the web of the foot of the frog, in which it is seen that the blood corpuscles circulate only in single series, the pigment cells, cellular tissue of the parenchyma, and the beautiful hexagonal and nucleated tessellate epidermis are likewise exhibited. This figure is magnified to the same extent as the last. 


$$
8
$$





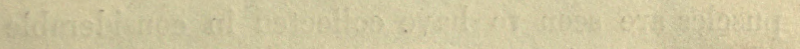

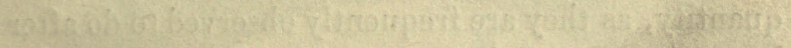

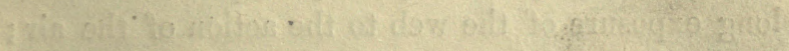

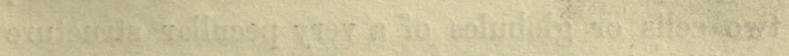

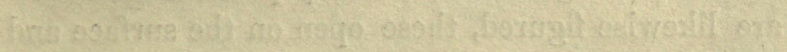

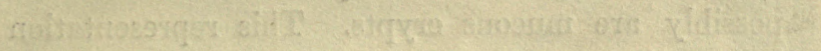

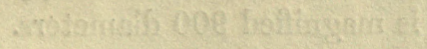




\section{Plate VI.}

Fig. 1. Is a more highly magnified representation of the circulation in the capillaries of the web of the foot of the frog; in it the white and red corpuscles as well as the epidermis are more clearly defined, two of the white corpuscles are seen to be of an oval form, resulting from compression between the red blood discs and the walls of the vessels. This figure is magnified 670 diameters.

2. Exhibits a portion of a larger vessel also taken from the web of the foot of the frog, in it the white corpuscles are seen to have collected in considerable quantity, as they are frequently observed to do after long exposure of the web to the action of the air; two cells or globules of a very peculiar structure are likewise figured, these open on the surface and possibly are mucous crypts. This representation is magnified 900 diameters. 

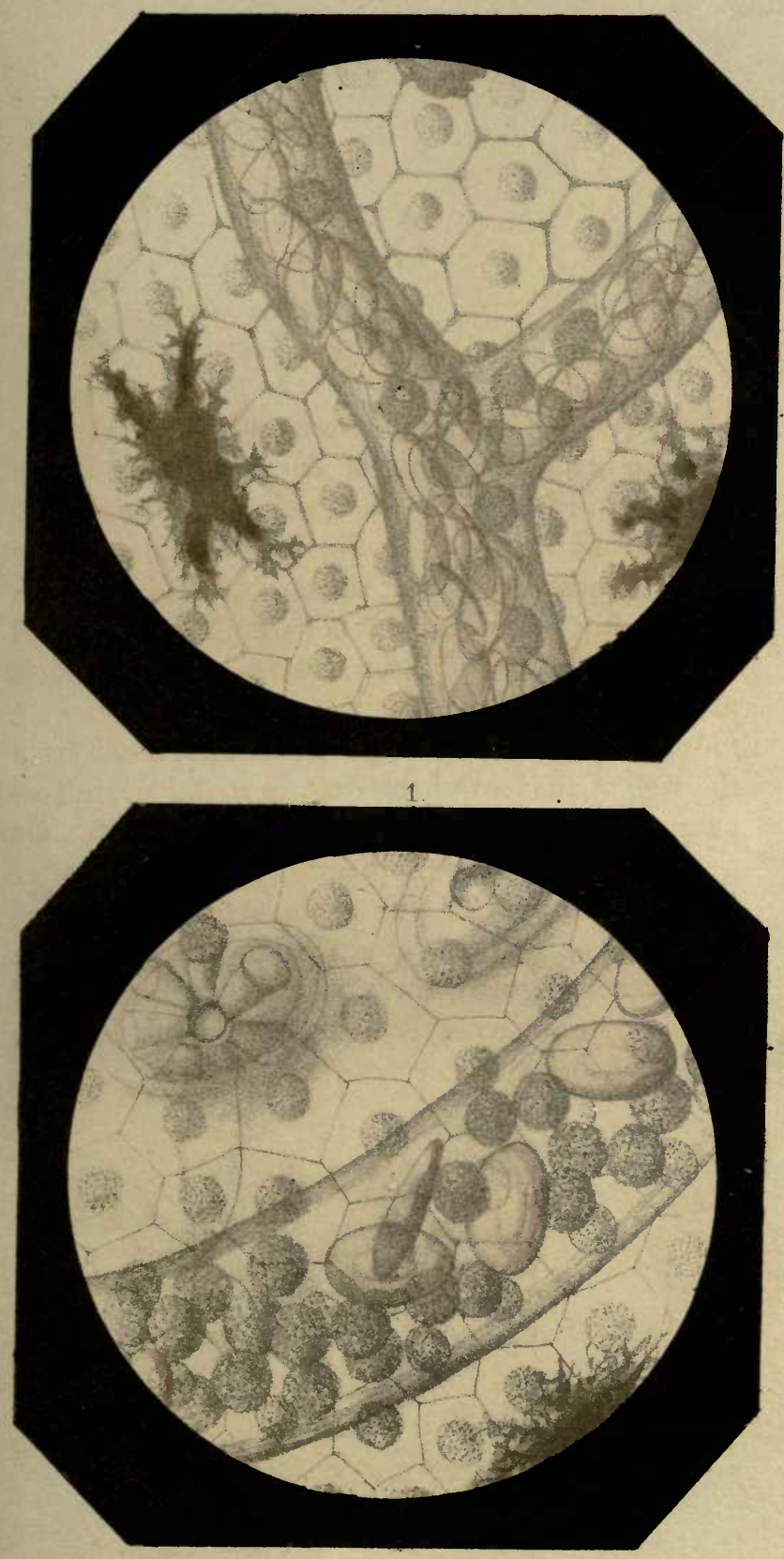



\section{Plate VII.}

Obs. It is scarcely necessary to observe, that the comparative anatomy figures are introduced in this work for the purpose of illustrating in a more satisfactory manner than could be otherwise accomplished, certain points, especially the more obscure ones, connected with human anatomy.

These figures should, therefore, by no means be regarded as taking the place of any of those which should illustrate human anatomy, and not one of which, deemed to be of importance, will on any account be omitted; they should be deemed not as substitutes, but as additions to the original design of the work, and which cannot but enhance very considerably its value.

Fig. 1. Represents a portion of the under surface of the tongue of the frog, magnified 130 diameters, and on which are seen, first, numerous glands, mostly spherical, and traversed by a tortuous vessel in which the blood corpuscles are tossed about as it were in a vortex; and, second, mucus crypts, the apertures of which are apparent. Donné has observed these bodies, but believes them to be formed by nervous loops, and appears to have overlooked the orifices alluded to: these I found to be figured in a drawing of the tongue of the frog, sent me by Dr. Waller, but unaccompanied by any explanation.

Fig. 2. A portion of the same, magnified 500 diameters, shewing the incurrent and excurrent vessel of the gland, the mucus crypts, and the net-work formed by the epithelium. 

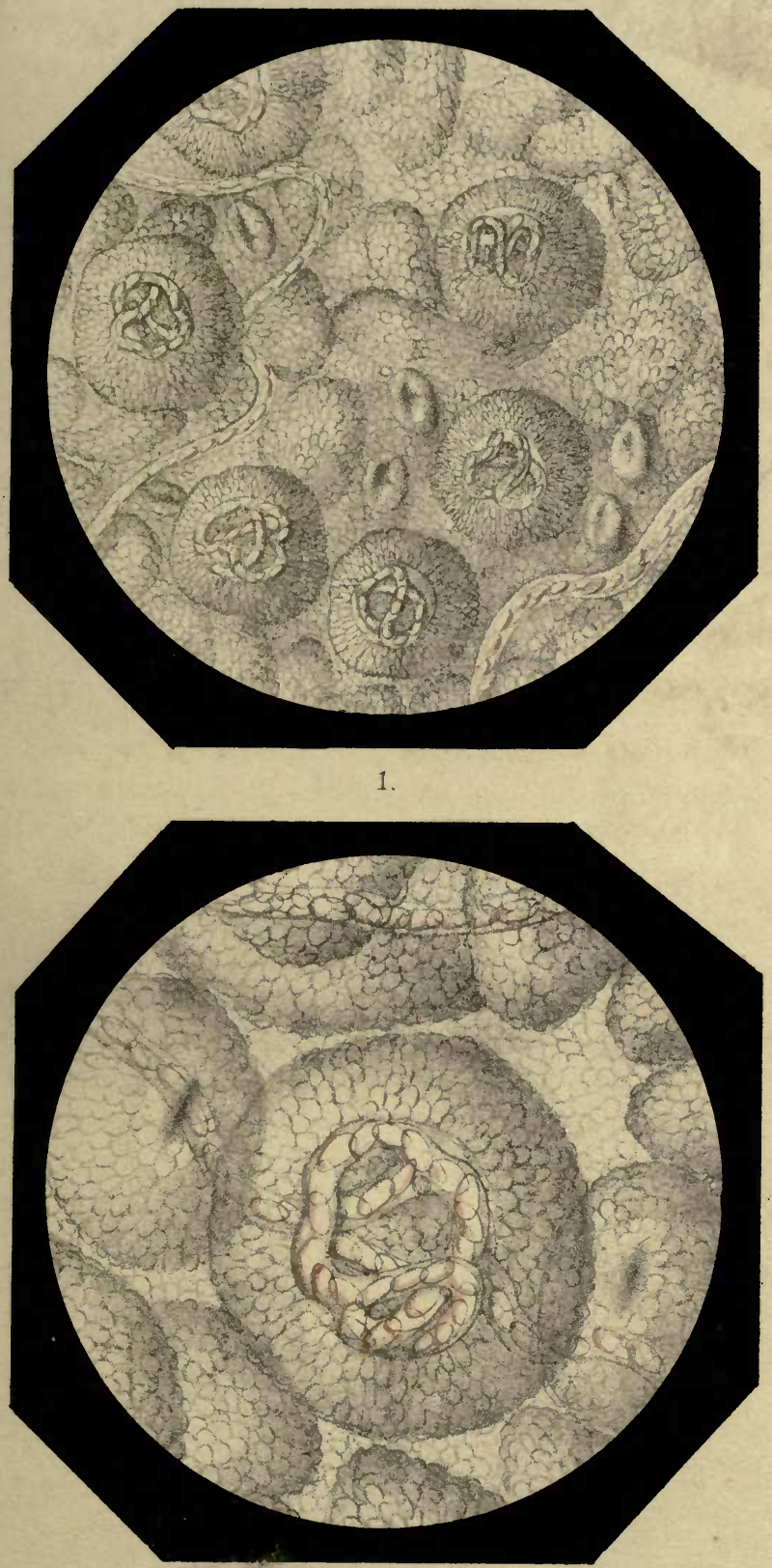



\section{Plate IX.}

\section{DEVELOPMENT AND DISSOLUTION OF THE RED BLOOD CORPUSCLE.}

Fig. 1. Represents the development of the red blood corpuscle of the embryo fowl, on the third day of its growth, obtained from one of the vessels of the arca vasculosa: this is seen to be of many different sizes, the smaller being scarcely a third the volume of the larger discs, and consisting of but little more than a nucleus and an envelope. Numerous molecules are likewise visible, scattered over the field.

Fig. 2. The same in water.

Fig. 3. The red blood corpuscles of the adult fowl, mostly in different stages of dissolution; the larger and deeply coloured corpuscles, represent the fully developed discs; the larger and pale ones, with the distinct nuclei, those the dissolution of which has just commenced; the smaller and colourless ones, red blood discs in advanced stages of dissolution, the sole remains of which at length is the nucleus, also represented in the figure.

Fig. 4. The red blood corpuscle of the young frog in different stages of development. First, it is seen as a small and granular body of a circular form; secondly, it assumes an oval shape, but still retains its granular constitution, and but little exceeds its former dimensions. In this its second stage of development it is still colourless : it soon however grows in size, and acquires a greater or less degree of coloration; so that when it has attained one half or two thirds of its size, it is nearly as deeply coloured as the full-grown blood disc: the colourless granular nucleus and the coloured and perfectly smooth outer portion of each globule are not at first distinctly 
separated from each other, the former being at its origin rather large and without any defined margin : it soon however shrinks in size, and assumes a regular oval shape. Crescentic bodies, occasionally met with in the blood of the frog, and probably of vegetable nature, are also represented in the figure.

Fig. 5. The red blood corpuscle of the adult frog, in different stages of dissolution. In examining a drop of the blood of a full-grown frog, a much greater uniformity in the size of the red blood discs will be observed, than exists in that of the very young animal, fewer corpuscles being in process of development in the former than in the latter.

Fig. 6. Blood corpuscles of the adult frog united into chains, an arrangement which appears to be intimately connected with the coagulation of the fibrin. 



\section{Plate $\mathrm{X}$.}

DEVELOPMENT OF THE EMBRYO OF THE CHICK.

Fig. 1. The appearance of the cicatricula in the yolk prior to incubation.

Fig. 2 The same at the end of the first day of incubation; the halones are now distinctly visible, as also the arca pellucida, and nota primativa, or first rudiment of the young chick.

Fig. 3. The same at the termination of the thirty-sixth hour of incubation; the halones have become more marked and expanded, the nota primitiva larger, and traces of blood-vessels are now for the first time distinctly visible in the germinal membrane.

Fig. 4. The same at the close of the second day; the pulsation of the heart and the vessels of the arca vasculosa are clearly visible; within them the coloured corpuscles may be seen circulating.

Fig. 5. The same at end of the third day of development; the arca vasculosa has now extended itself to two or three times its former dimensions.

Fig. 6. The embryo on the conclusion of the fourth day; the head, the eye, and the budding of the allantois are now seen in addition to the parts previously noticed.

Fig. 7. The embryo at the termination of the fifth day; the wing and the foot have made their appearance; the limits of the arca vasculosa cannot now be seen, it extending over two thirds of the surface of the egg; after this and the following day, the periods of its complete development, the arca suffers an arrest of growth, and the vessels contract and carry but little blood, until at length they are entirely obliterated. The allantois has on this day attained a considerable size, and its further growth proceeds with the utmost rapidity. 
Fig. 8. The embryo six days old with the allantois separated from the arca vasculosa and the yolk, \&c.

Fig. 9. The embryo of the ninth day of development, seen through the allantois, which now invests nearly the entire surface of the yolk, and beneath which the collapsed and faintly coloured vessels of the arca vasculosa may still be discerned. The purpose fulfilled by the distribution of such innumerable vessels in the membrane of the arca vasculosa, and, subsequently in the allantois, is but temporary, and is doubtless connected with respiration, the blood in these vessels being submitted to the influence of the oxygen of the air which enters the egg through the pores contained in its shell; the vital fluid is thus regenerated and afterwards reconveyed to the embryo itself, from which it first proceeded. At the completion of the development of the chick, the allantois undergoes the same obliteration of its vessels which the arca vasculosa previously suffered. Fig. 10. The embryo at the end of the seventh day of development removed from its membranes.

Fig. 11. The same at the end of the ninth day, also separated from its membranes.

Such is a brief sketch of the marvellous development of the embryo of the chick. 


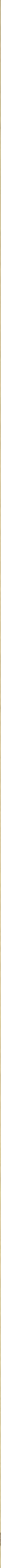





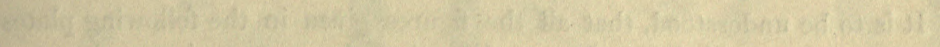

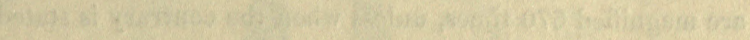

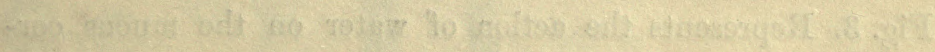

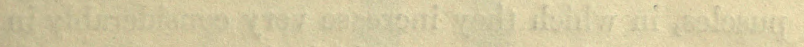

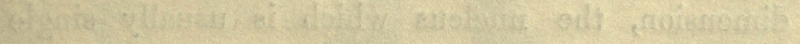

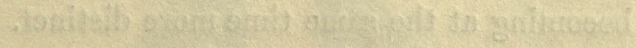

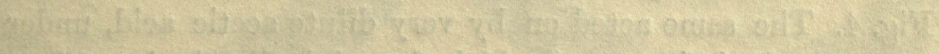

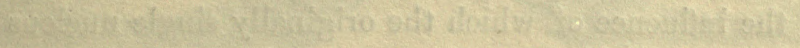

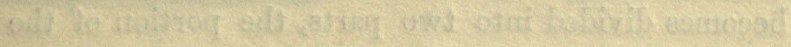

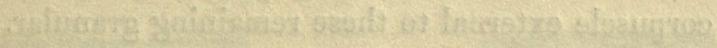

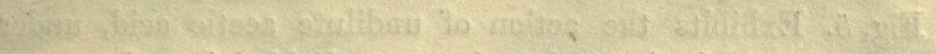

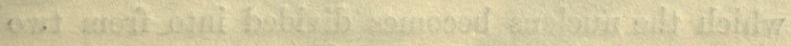

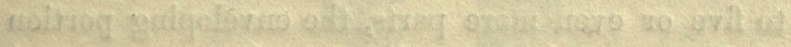

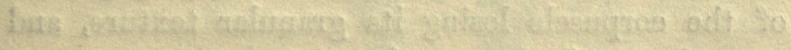

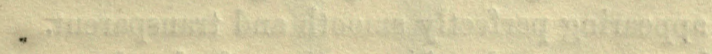

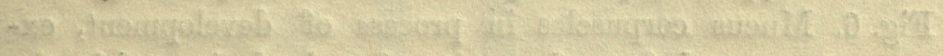

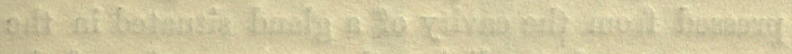

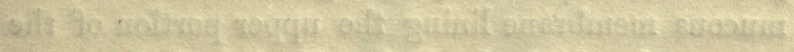

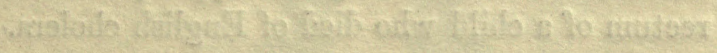




\section{EXPLANATION OF THE PLATES.}

It is to be understood, that all the figures given in the following plates are magnified 670 times, unless when the contrary is stated.

\section{Plate XI.}

MUCUS.

Fig. 1. Mucus corpuscles of their ordinary size, form, and appearance.

Fig. 2. The same collapsed, owing to the density of the fluid in which they are contained; these corpuscles are capable of resuming the circular form by the addition of water.

Fig. 3. Represents the action of water on the mucus corpuscles, in which they increase very considerably in dimension, the nucleus which is usually single becoming at the same time more distinct.

Fig. 4. The same acted on by very dilute acetic acid, under the influence of which the originally single nucleus becomes divided into two parts, the portion of the corpuscle external to these remaining granular.

Fig. 5. Exhibits the action of undilute acetic acid, under which the nucleus becomes divided into from two to five or even more parts, the enveloping portion of the corpuscle losing its granular texture, and appearing perfectly smooth and transparent.

Fig. 6. Mucus corpuscles in process of development, expressed from the cavity of a gland situated in the mucous membrane lining the upper portion of the rectum of a child who died of English cholera. 

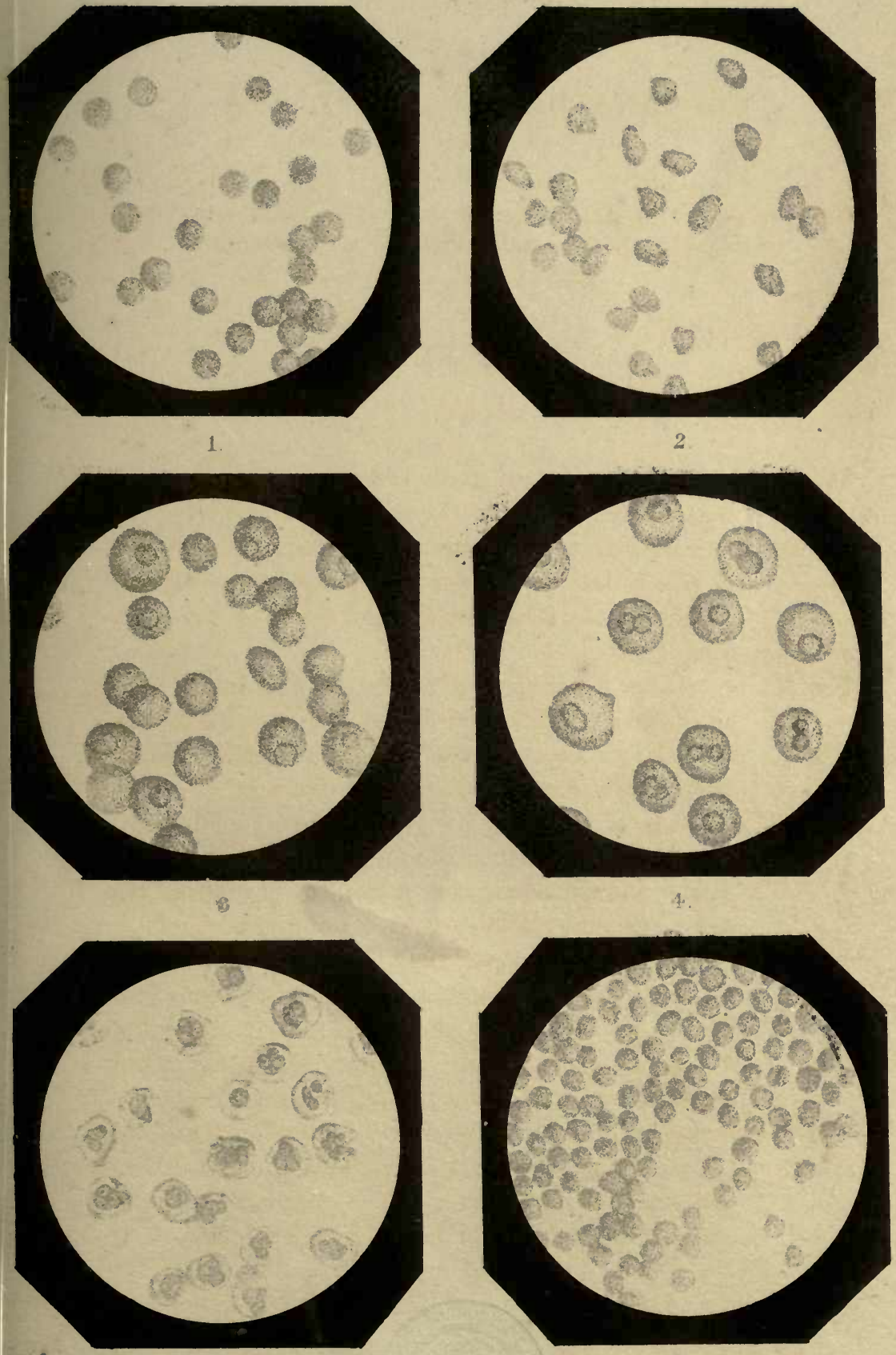

183093)

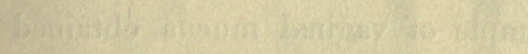

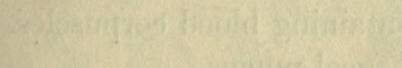

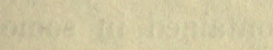

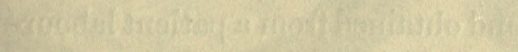

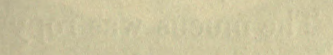

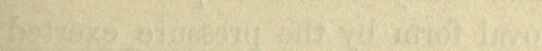

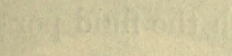

(20) 390

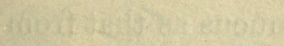

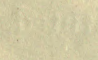$$
(6)^{-1}
$$

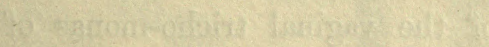

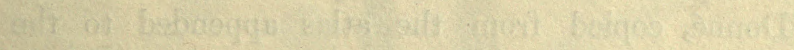

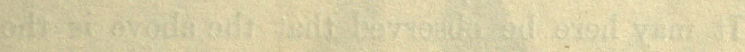

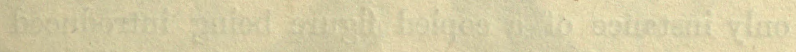

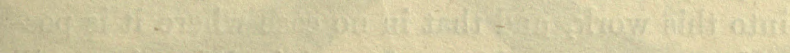

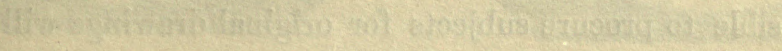

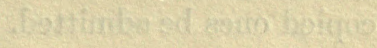




\section{Plate XII.}

\section{MUCUS.}

Fig. 1. Represents an example of vaginal mucus obtained during parturition, and containing blood corpuscles.

Fig. 2. Is a representation of œesophageal mucus.

Fig. 3. Exhibits the mucous corpuscles contained in some bronchitic mucus, and obtained from a patient labouring under chronic bronchitis. The mucus was ropy and tenacious, and many of the corpuscles were rendered of an oval form by the pressure exerted upon them by the filaments, of which the fluid portion of true mucus is constituted.

Fig. 4. Vegetation contained in the same mucus as that from which the previous figure was made.

Fig. 5. Mucus from the stomach.

Fig. 6. Is a representation of the vaginal tricho-monas of Donné, copied from the atlas appended to the "Cours de Microscopie."

It may here be observed that the above is the only instance of a copied figure being introduced into this work, and that in no case where it is possible to procure subjects for original drawings will copied ones be admitted. 



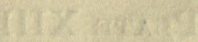

\section{ketres}

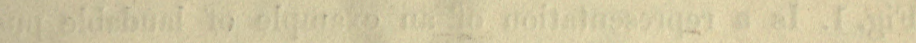

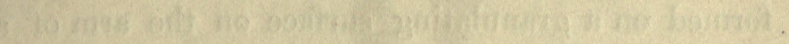

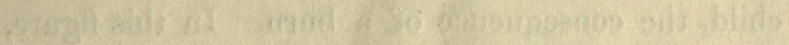

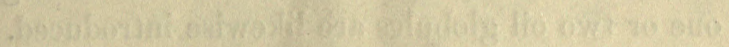

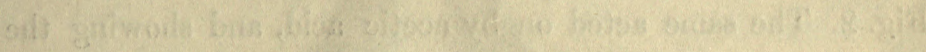

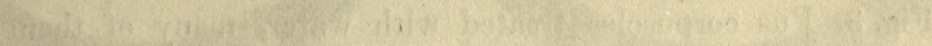

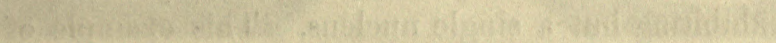
a)

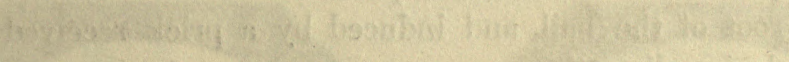

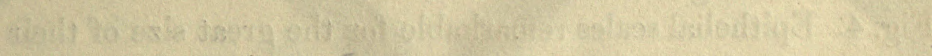

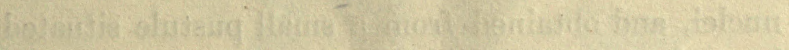

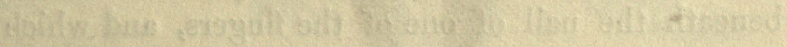

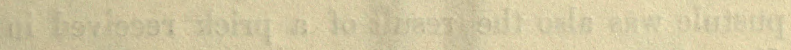
c)

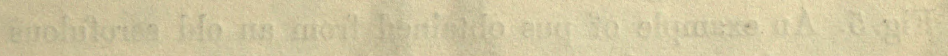

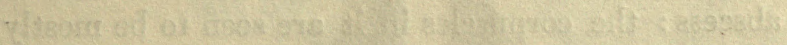

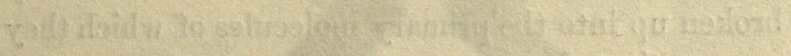

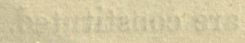

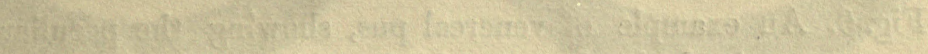

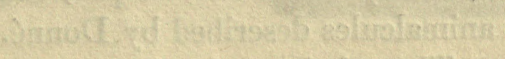

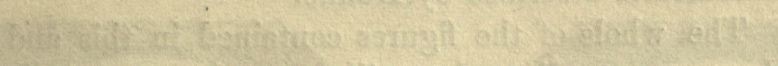

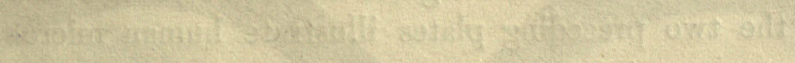




\section{Plate XIII. \\ PUS.}

Fig. 1. Is a representation of an example of laudable pus formed on a granulating surface on the arm of a child, the consequence of a burn. In this figure, one or two oil globules are likewise introduced.

Fig. 2. The same acted on by acetic acid, and showing the compound nuclei.

Fig. 3. Pus corpuscles treated with water, many of them exhibiting but a single nucleus. This example of pus was obtained from a pustule formed around the root of the nail, and induced by a prick received during dissection.

Fig. 4. Epithelial scales remarkable for the great size of their nuclei, and obtained from a small pustule situated beneath the nail of one of the fingers, and which pustule was also the result of a prick received in dissecting.

Fig. 5. An example of pus obtained from an old scrofulous abscess : the corpuscles in it are seen to be mostly broken up into the primary molecules of which they are constituted.

Fig. 6. An example of venereal pus, showing the peculiar animalcules described by Donné.

The whole of the figures contained in this and the two preceding plates illustrate human microscopic anatomy. 

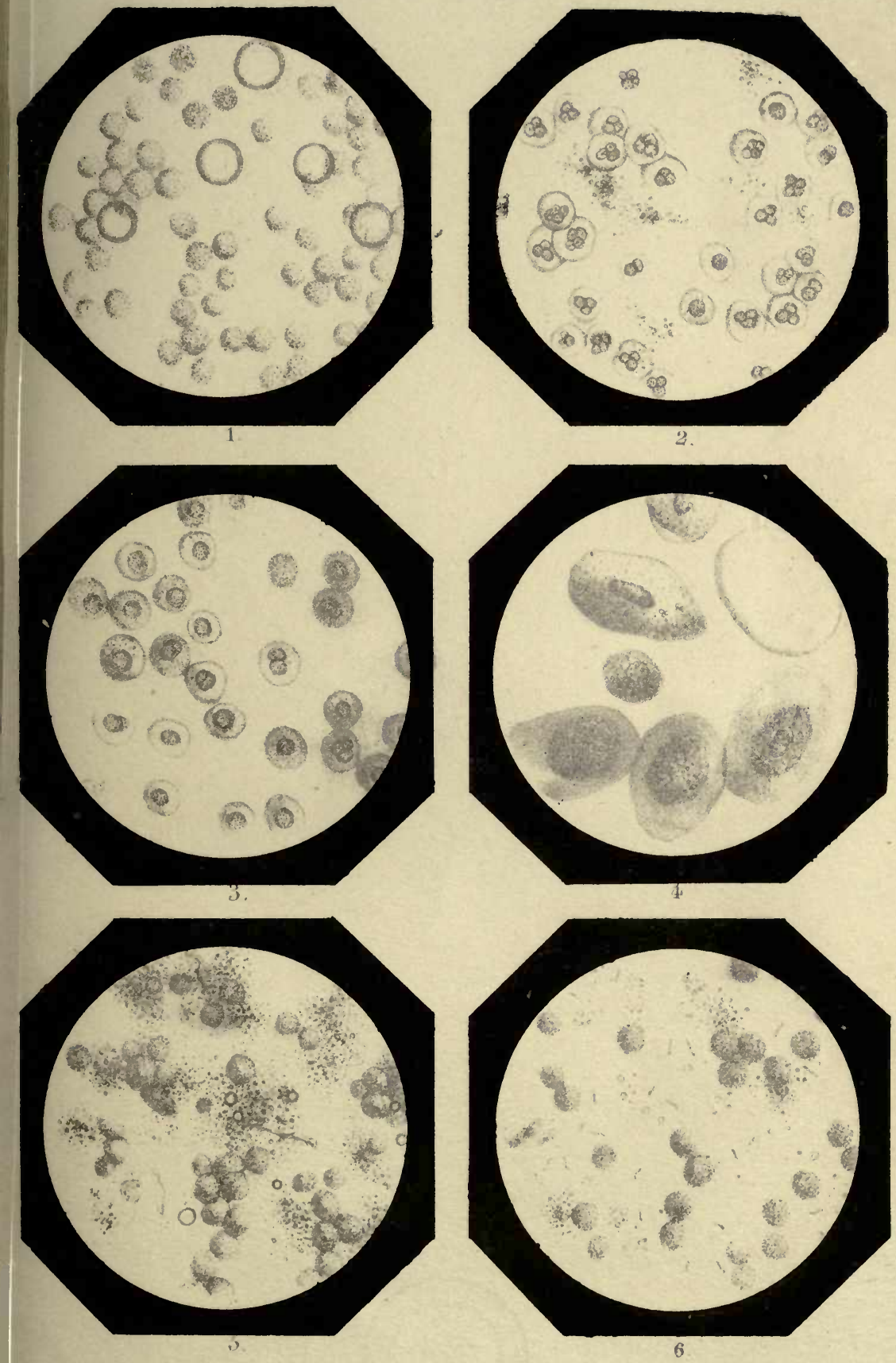


\section{EXPLANATION OF THE PLATES.}

It is to be understood, that all the figures given in the following plates are magnified 670 times, unless when the contrary is stated.

\section{Plate XIV.}

MILK.

Fig. 1. The globules of the healthy milk of a woman.

Fig. 2. The globules contained in impoverished human milk, which are seen to be smaller in size and fewer in number than in ordinary milk.

Fig. 3. An example of colostrum, on the first day, obtained from a young woman aged 19, delivered of her first child, and showing the size and arrangement of the ordinary milk globules, as well as the structure and appearance of the peculiar colostrum corpuscles.

Fig. 4. The same colostrum of the same age, containing a greater number of the colostrum corpuscles.

Fig. 5. The same colostrum, on the same day, exhibiting the great size of the cream globules, which appear frequently to present rather the aspect of oil than that of true milk globules.

Fig. 6. The milk globules aggregated into masses, as occurs in cases of engorgement of the breast. 

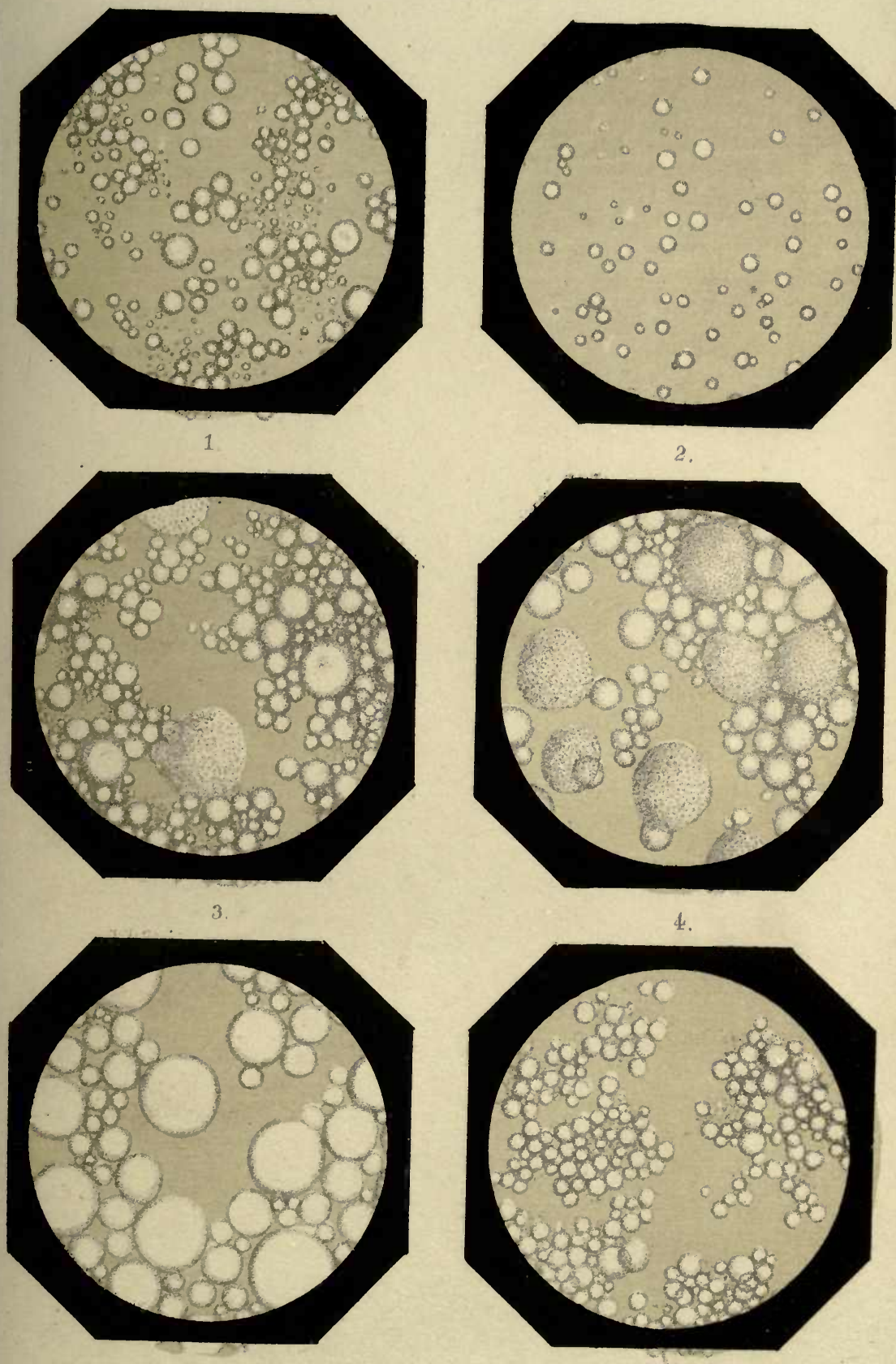


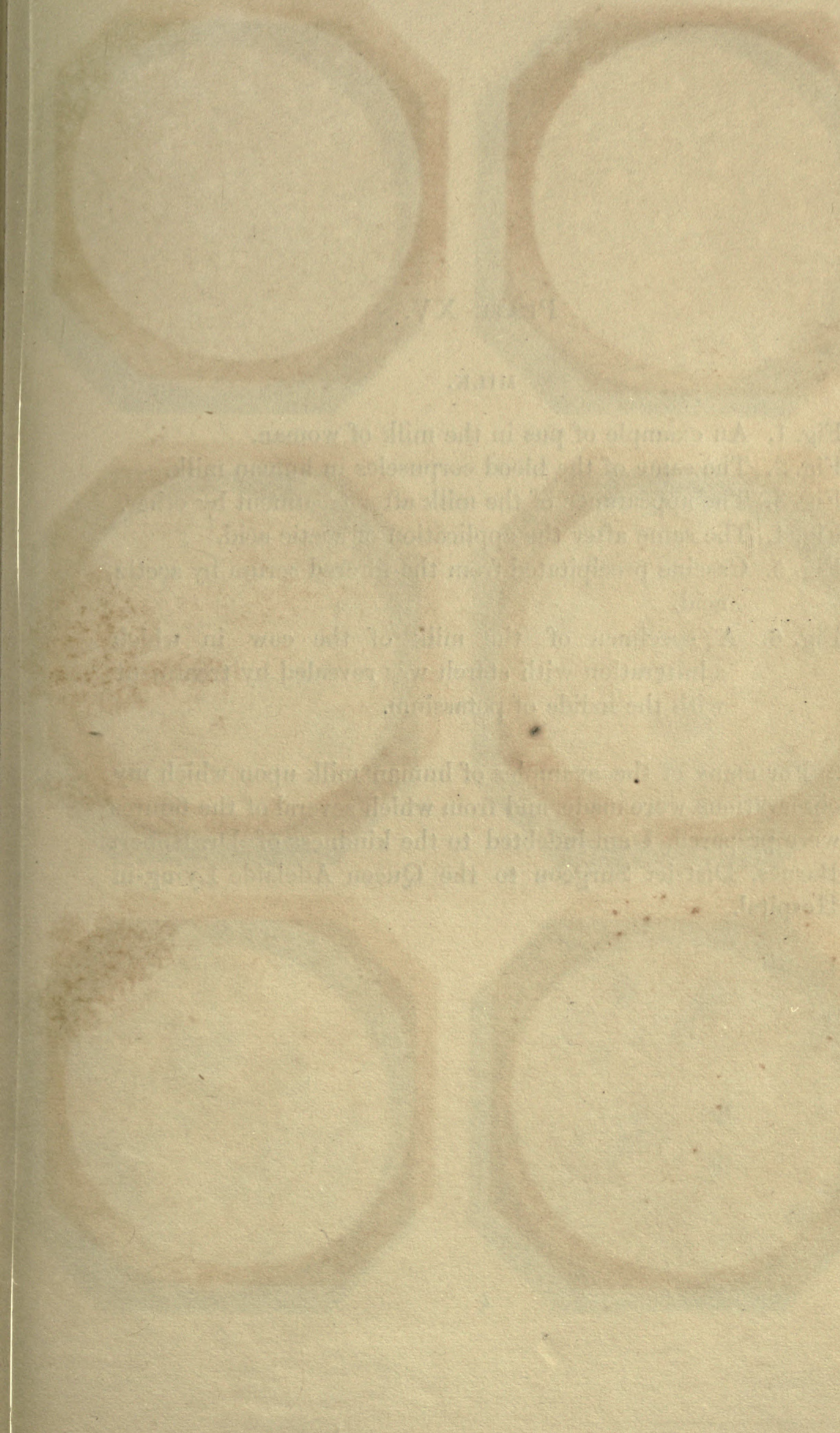

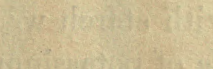
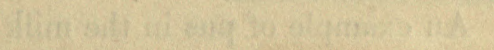

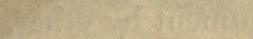
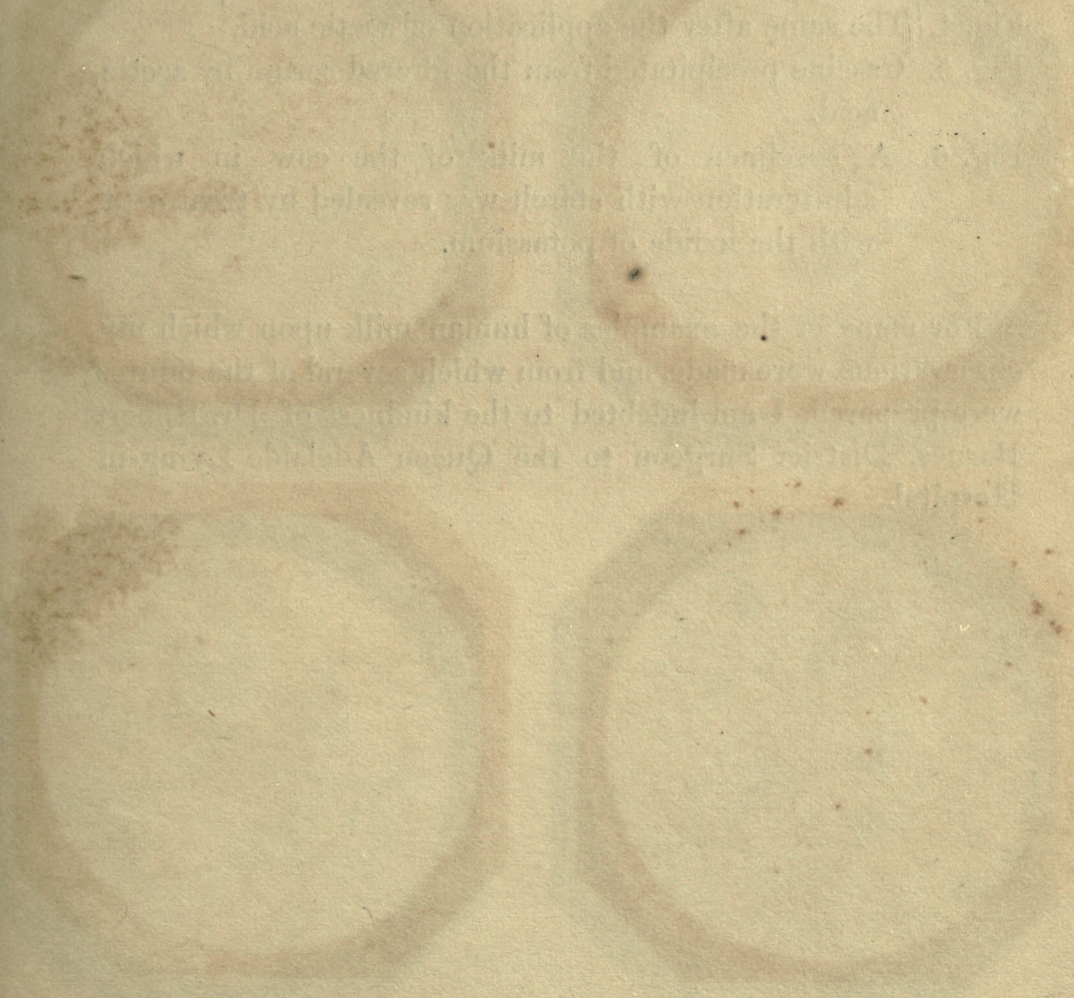


\section{Plate XV,}

\section{MILK,}

Fig. 1. An example of pus in the milk of woman.

Fig. 2. The same of the blood corpuscles in human milk.

Fig. 3. The appearance of the milk after treatment by ether,

Fig, 4. The same after the application of acetic acid.

Fig. 5. Caseine precipitated from the filtered serum by acetic acid,

Fig. 6. A specimen of the milk of the cow in which adulteration with starch was revealed by treatment with the iodide of potassium.

For many of the examples of human milk upon which my observations were made, and from which several of the figures were prepared, I am indebted to the kindness- of Dr. Robert Barnes, District Surgeon to the Queen Adelaide Lying-in Hospital. 

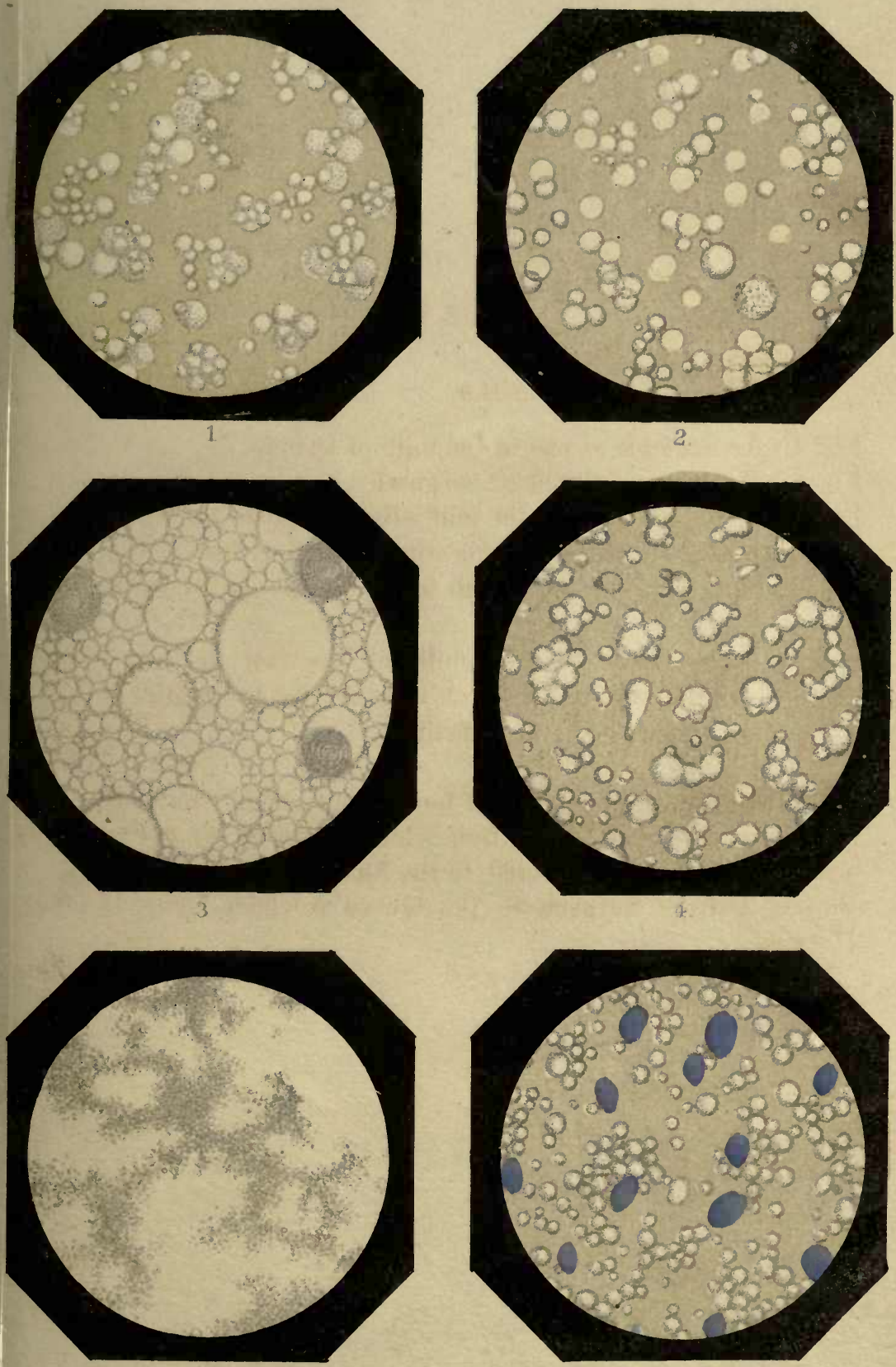



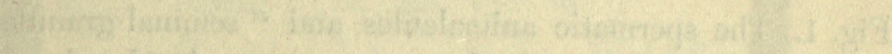

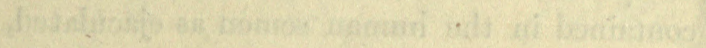

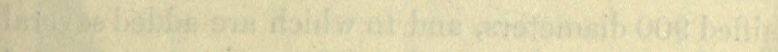

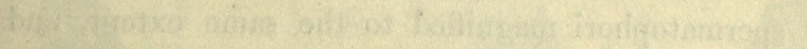

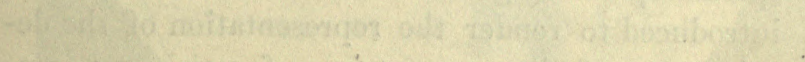

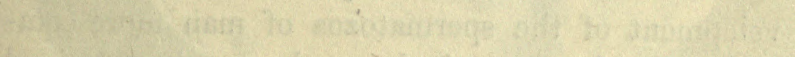

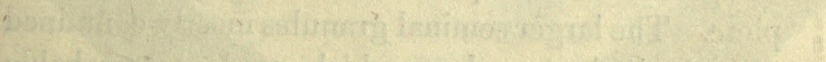

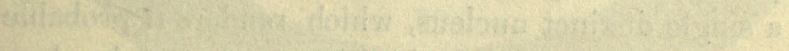

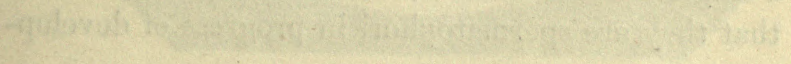

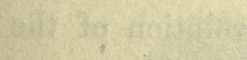

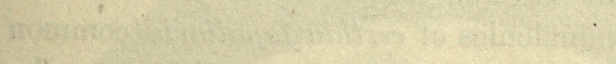

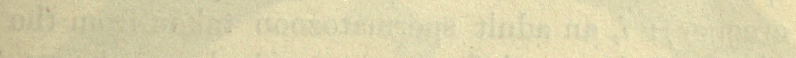

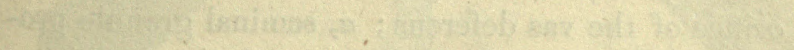

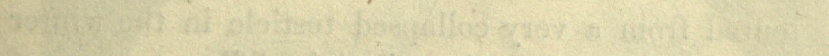

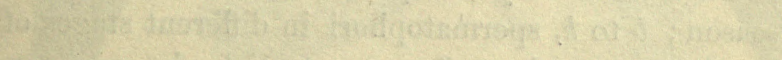

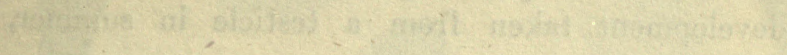
a. 1
1

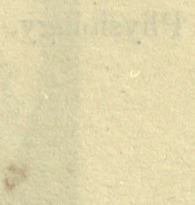




\section{Plate XVI.}

\section{SEMEN.}

Fig. 1. The spermatic animalcules and "seminal granules" contained in the human semen as ejaculated, magnified 900 diameters, and to which are added several spermatophori magnified to the same extent, and introduced to render the representation of the development of the spermatozoa of man more complete. The larger seminal granules mostly contained a single distinct nucleus, which renders it probable that they are spermatophori in progress of development.

Fig. 2. Represents the several stages of evolution of the spermatic animalcules of certhia familiaris (common creeper); $l$, an adult spermatozoon taken from the orifice of the vas deferens; $a$, seminal granule procured from a very collapsed testicle in the winter season; $b$ to $k$, spermatophori in different stages of development taken from a testicle in summer, during turgescence.

This figure is copied from Wagner's Elements of Special Physiology. 


$$
8
$$





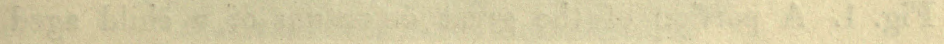

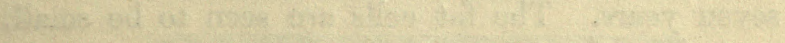

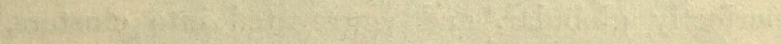

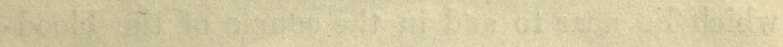

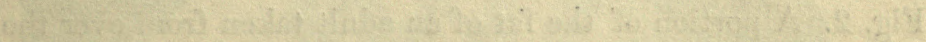

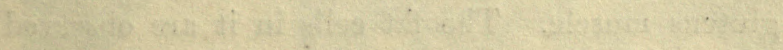

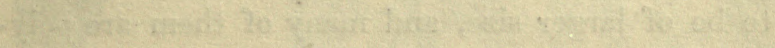
an: 


\section{EXPLANATION OF THE PLATES.}

The figures contained in this and the following plate are magnified 130 diameters.

\section{Plate XVIII.}

FAT.

Fig. 1. A portion of the great omentum of a child aged seven years. The fat cells are seen to be small, perfectly globular, and aggregated into clusters, which lie near to and in the course of the bloodvessels.

Fig. 2. A portion of the fat of an adult taken from over the gluteus muscle. The fat cells in it are observed to be of larger size, and many of them are polyhedral; these cells are also seen to be held in union by an enclosing membrane of cellular tissue. 
Plate, XVIII.

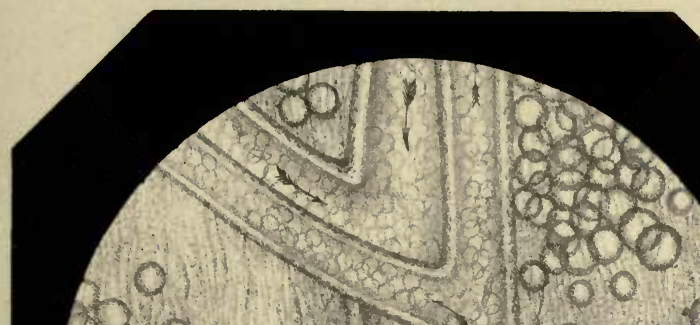

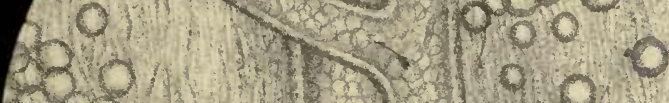

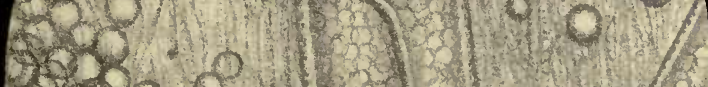

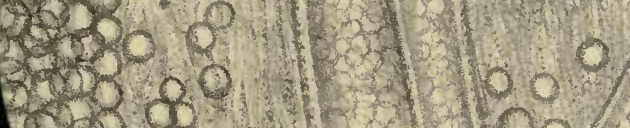
$0.000+0$

1002 Dow 00

10 $)$

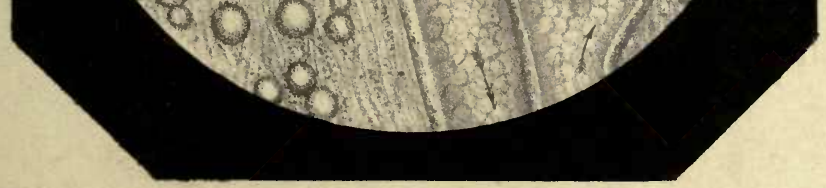

I

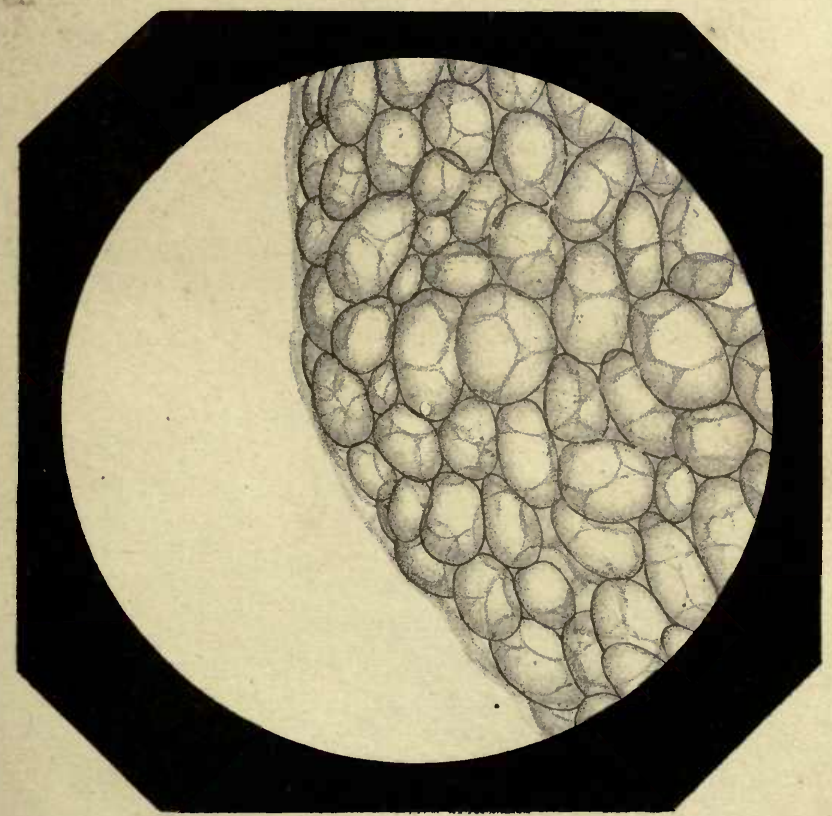

2 



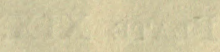

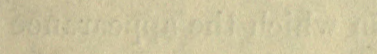

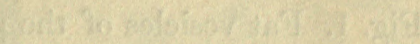

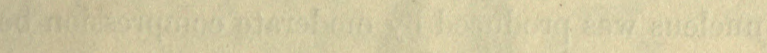

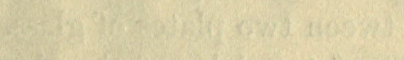

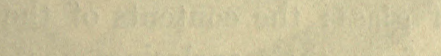

(av)

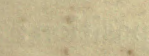

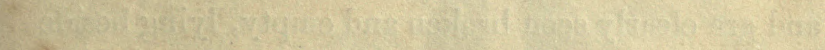




\section{Plate XIX.}

FAT.

Fig. 1. Fat vesicles of the pig, in which the appearance of a nucleus was produced by moderate compression between two plates of glass.

Fig. 2. The fat vesicles of the pig ruptured by compression between two plates of glass: the contents of the cells are seen escaping from their enclosing membranes.

Fig. 3. Fat cells, forming part of the marrow contained in the femur of a child aged about ten years; in these a large nucleus-like body is visible, the formation of which probably depended upon a change in the condition of the contents of the cells induced by decomposition.

Fig. 4. The same cells in a further stage of decomposition: the membranes of the cells have become ruptured, and are clearly seen broken and empty, lying beside their escaped contents, which either become broken up and assume the form of drops of oil of different sizes, or remain entire, in which case they frequently exhibit the crystalline appearance portrayed in figure 5.

Fig. 5. Human fat vesicles, on the surface of which crystals, supposed to be those of margaric acid, radiating from a centre, have appeared; their presence is to be regarded as an indication that decomposition has begun to affect the contents of the cells.

Fig. 6. Fat cells, contained in a small melicerous tumour removed from over the nasal bones, in all of which a nucleus-like body was clearly visible.

The tumour from which the figure was taken was kindly forwarded for examination by $\mathrm{Mr}$. Ransom, of the University College Hospital. 


The figures in this plate are magnified to the same extent as those of most of the plates illustrating the work, viz. 670 diameters.

\section{Plate XX.}

Fig. 1. Buccal epithelial cells in different stages of development, from their earliest condition, in which they bear the form of mucous corpuscles, to their fully developed state. For a representation of the epithelial cells of the vagina and œsophagus, see Plate XII. figs. 1 and 2.

2. Cylindrical or cuneiform epithelial cells taken from the duodenum of a child seven days old: those of the adult are in every respect identical; the group of angular cells at the inferior part of the figure represents the summits of the cuneiform epithelial cells. 
Plate.XX
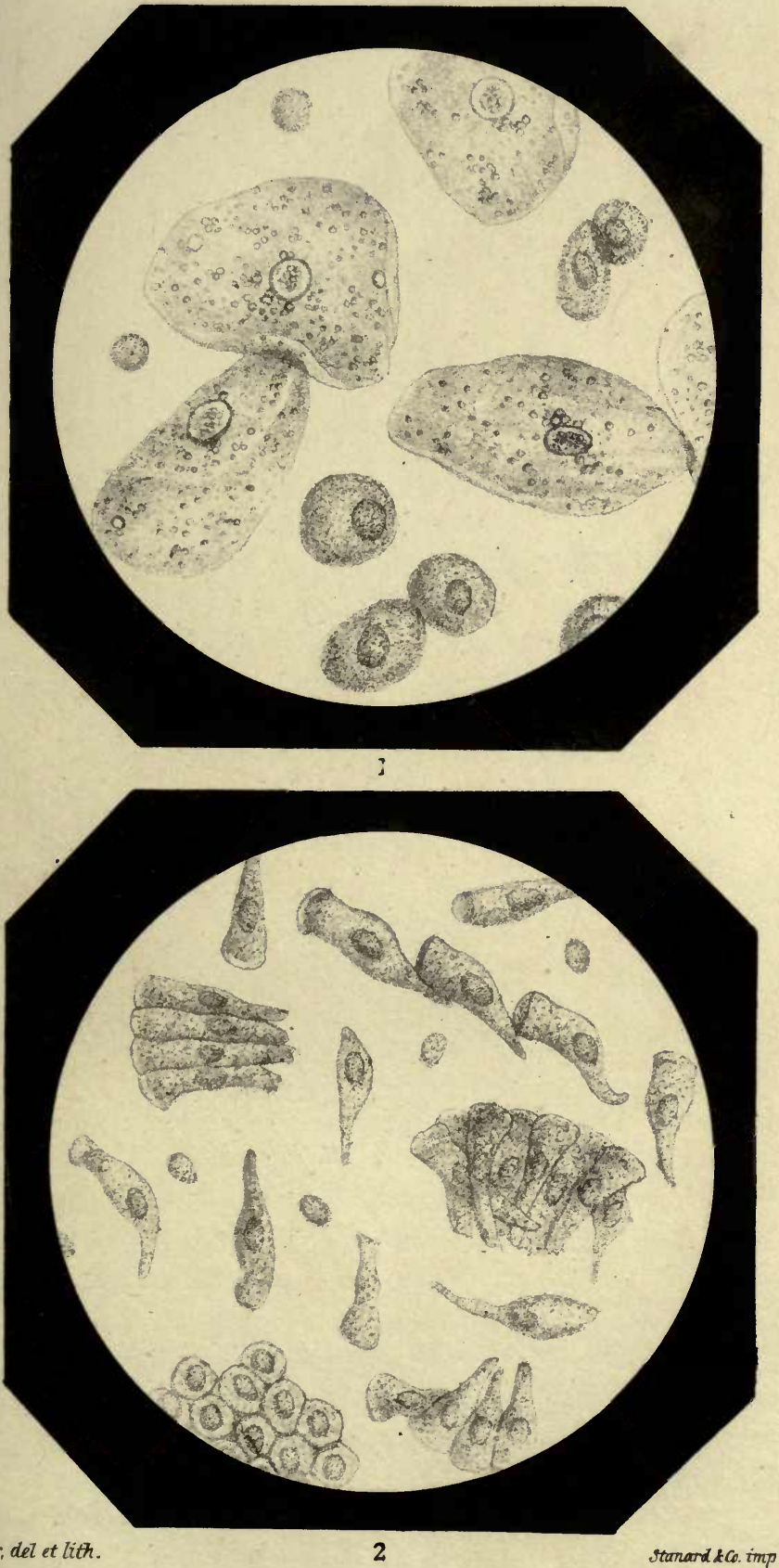



\section{EXPLANATION OF THE PLATES.}

\section{Plate XXI.}

Fig. 1. Ciliary epithelium from the trachea of the frog; it will be seen that the form of the cells is very different from that of mammalia.

Fig. 2. Human ciliary epithelium contained in the fluid expressed from a portion of lung taken from its extreme periphery, and apparently consisting of aircells alone. It is mixed up with cells of tesselated epithelium.

Fig. 3. Human ciliary epithelium from the trachea; both side and end views of the cells are given.

Fig. 4. Tesselated epithelium from the tongue of the frog.

Fig. 5. Tesselated epithelium from the tongue of the Triton: the nuclei are seen to be very large, their great size affording an illustration of the law which has already been announced, viz. that all the corpuscular elements of the animal organisation, whether those of the epithelium, the glands, cartilages or muscles stand in relation with the dimensions of the blood discs; where these are large, the other corpuscles are formed on a similar relative seale.

It is probable that the law admits of extension, and that all the elements of the animal structure bear a relation in size to the red blood dises.

Mr. John Quekett made the interesting observation, some time since, that the relative size of the lacunæ of bone corresponded with that of the blood corpuscles, a further illustration of the accuracy of the law referred to. 
Wishing to test the truth of this law in as satisfactory and conclusive a manner as possible, I applied to Professor Owen for a specimen of the Siren or Proteus, animals remarkable for the dimensions of their blood discs, and that gentleman kindly placed at my disposal an example of the Menobranchus lateralis, a member of the same perennibranchiate group, and the blood corpuscles of which "are rather larger than those of the Proteus, but not so large as those of the Siren." In this animal I found, as I had anticipated, that the soundness of the law was fully maintained.

The law announced would doubtless be cited by those phyziologists who entertain the idea that all the corpuscular elements of the animal fabric proceed from the red blood disc, as a proof of the truth of their theory, against which, however, I conceive that sound and conclusive arguments may be urged. 

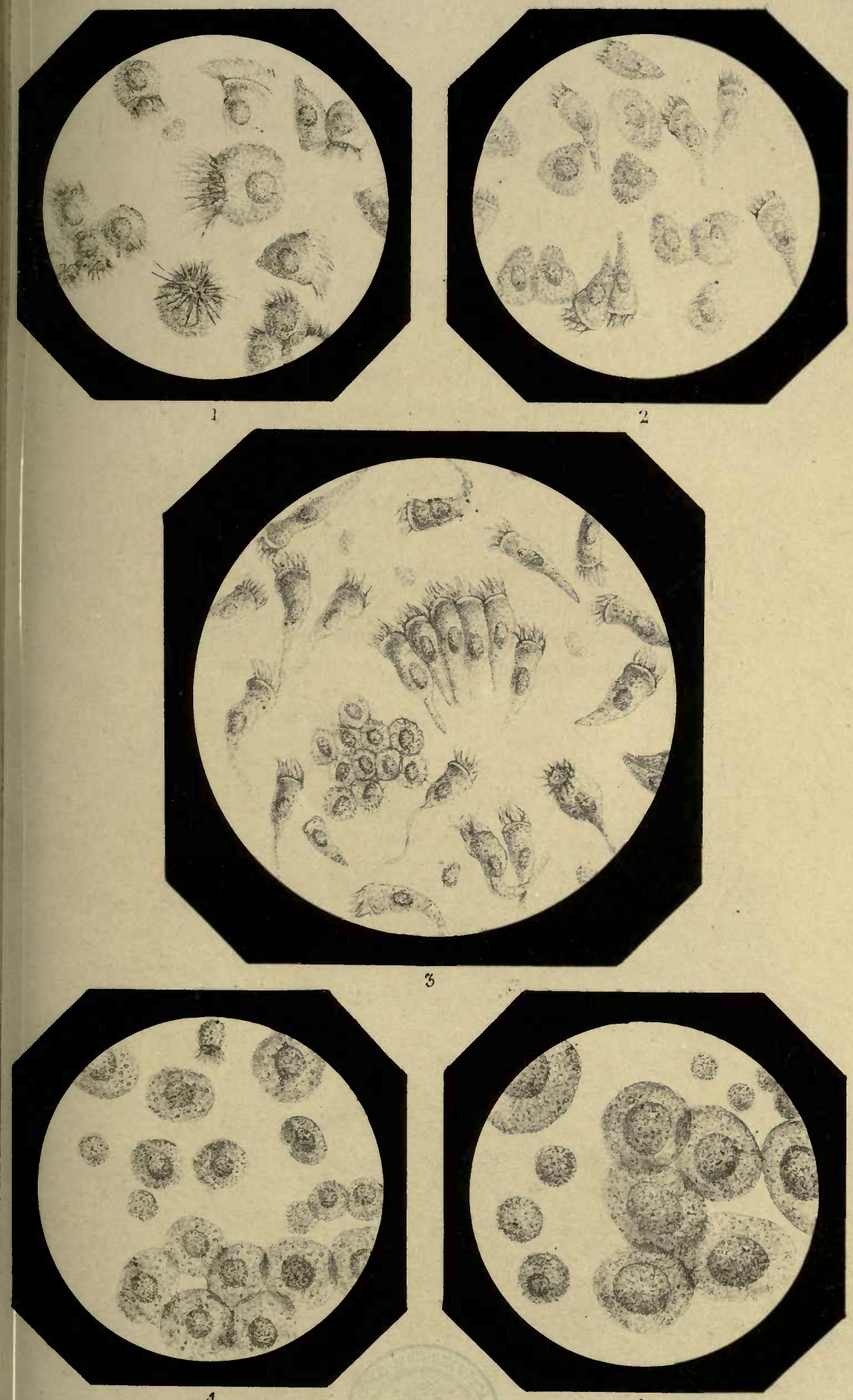

fitler, del et lith.

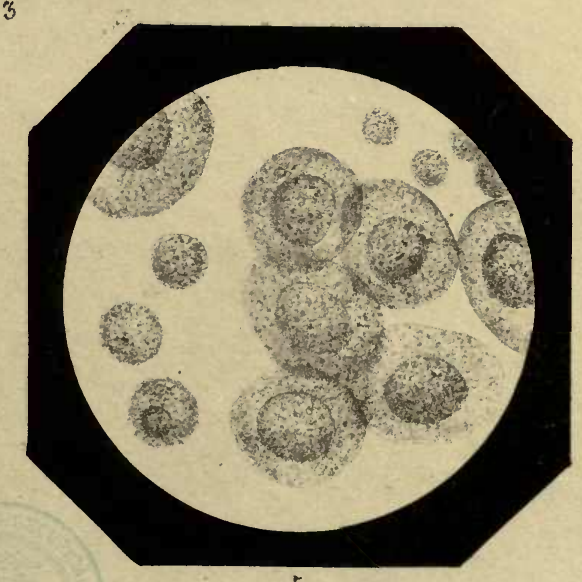





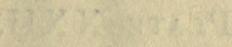

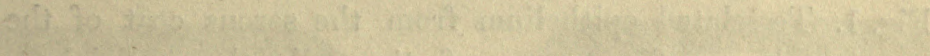

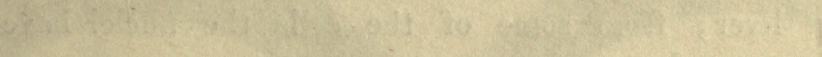

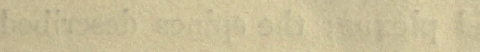

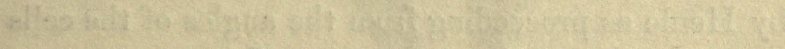

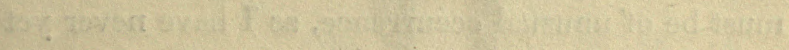

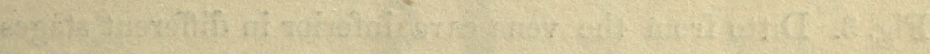

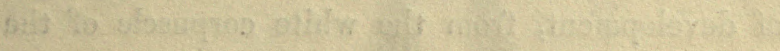

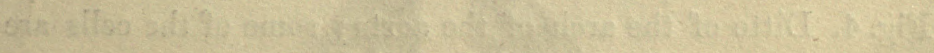

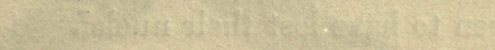

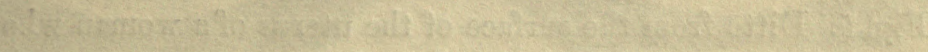

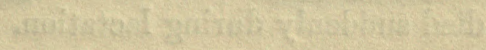

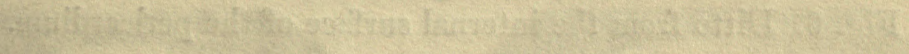




\section{Plate XXII.}

All the figures in this plate are human.

Fig. 1. Tesselated epithelium from the serous coat of the liver; from some of the cells the nuclei have escaped.

Fig. 2. Ditto from the choroid plexus; the spines described by Henle as proceeding from the angles of the cells must be of unusual occurrence, as I have never yet seen them.

Fig. 3. Ditto from the vena cava inferior in different stages of development, from the white corpuscle of the blood upwards.

Fig. 4. Ditto of the arch of the aorta; some of the cells are seen to have lost their nuclei.

Fig. 5. Ditto from the surface of the uterus of a woman who died suddenly during lactation.

Fig. 6. Ditto from the internal surface of the pericardium. 



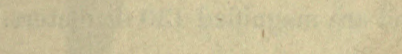

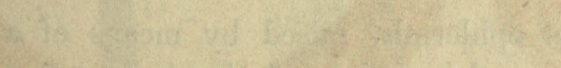

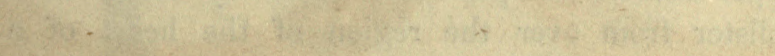

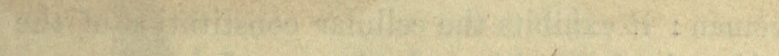

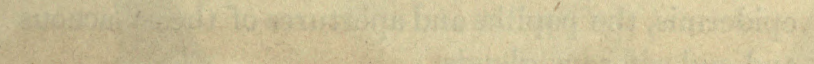

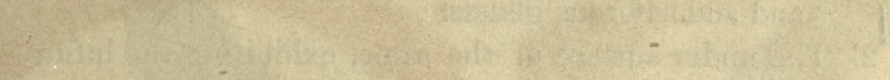




\section{Plate XXIII.}

The figures in this plate are human, and are magnified 130 diameters.

Fig. 1. Upper surface of epidermis, raised by means of a blister from over the region of the heart of a woman : it exhibits the cellular constitution of the epidermis, the papillæ and apertures of the sebaceous and sudoriferous glands.

Fig. 2. The under surface of the same, exhibiting the infundibuliform processes of the epidermis sent down to the sebaceous and sudoriferous glands. 
Plate7XIII
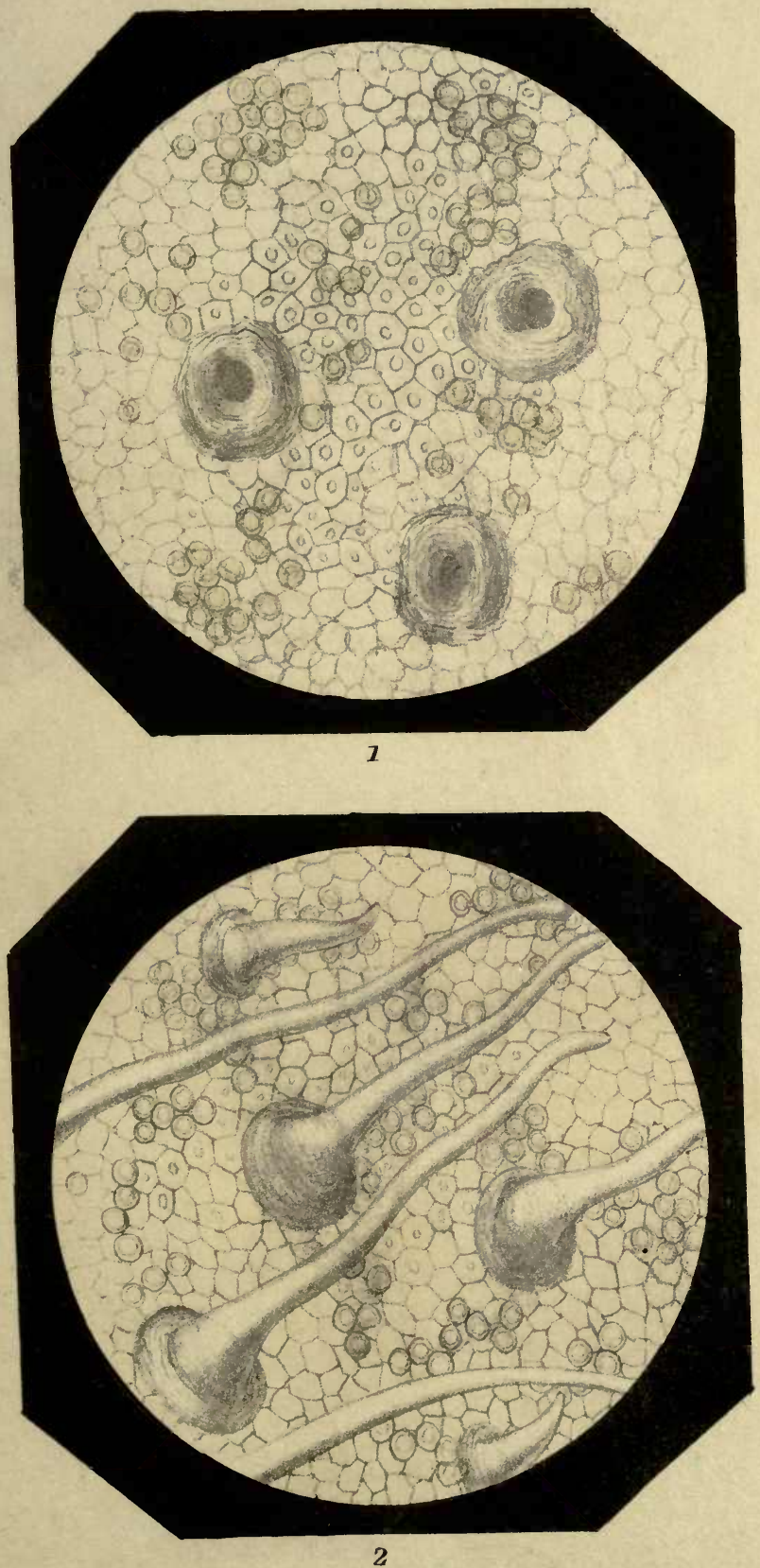



\section{Plate XXIV.}

STRUCTURE OF EPIDERMIS.

Fig. 1. A portion of the epidermis of the palm of the hand, magnified with a simple lens, showing the direction of the rugæ in that situation, and the arrangement of the apertures of the sudoriferous glands. Each of the ridges figured is made up of square compartments, the divisional lines of which run at right angles to the ridges, passing across the apertures referred to. These several compartments again are indented on their under surface with the papilla of the sensitive skin.

Fig. 2. A portion of the same magnified 100 diameters.

Fig. 3. A transverse section of the ridges of the epidermis of the palm of the hand, showing a side view of the apertures of the sudoriferous glands, their spiral ducts, the thickness of the epidermis in the situation mentioned, its composition of superimposed layers of cells, and its mode of connexion with the true skin.

Fig. 4. A longitudinal section of one of the ridges magnified to the same extent as the previous figure, viz. 100 diameters : in this the composition of the thickened epidermis of adherent layers of cells is better seen, and the difference in the form of the superficial and deeper seated cells may also be observed.

Fig. 5. A portion of the epidermis removed from the back and outer part of the hand, showing the disposition of the folds in that situation, the arrangement of the papillæ, the disposition of the hair follicles and 
hairs, and the apertures of the sudoriferous and sebaceous glands. Magnified with a simple lens.

Fig. 6. A piece of the same magnified 100 diameters, showing that each line is a furrow or groove, a provision which allows of a very great extension of the epidermis. 

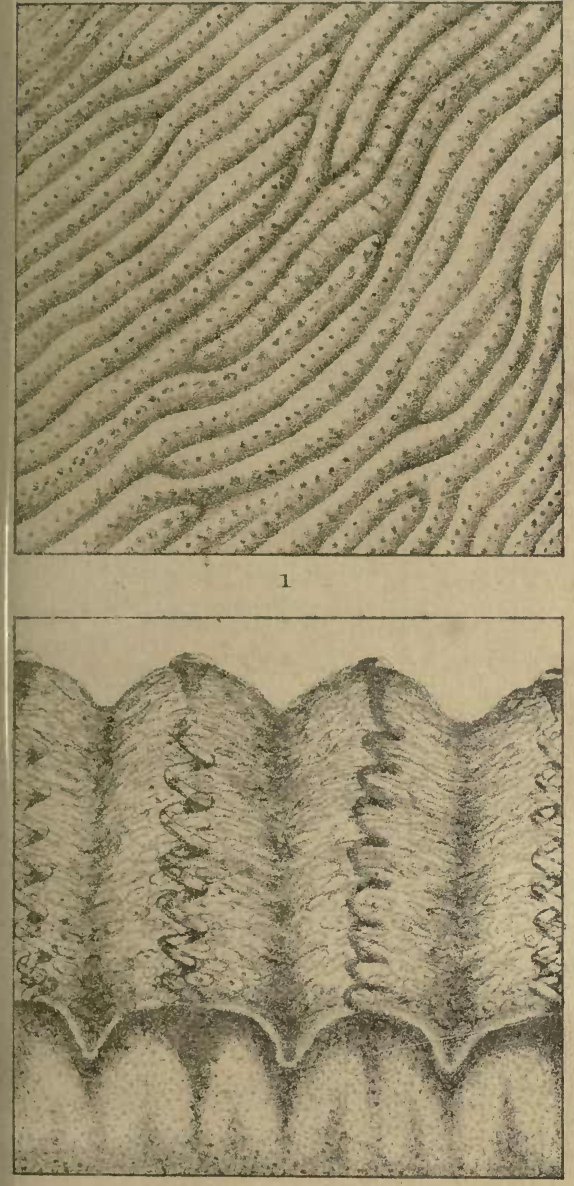

3

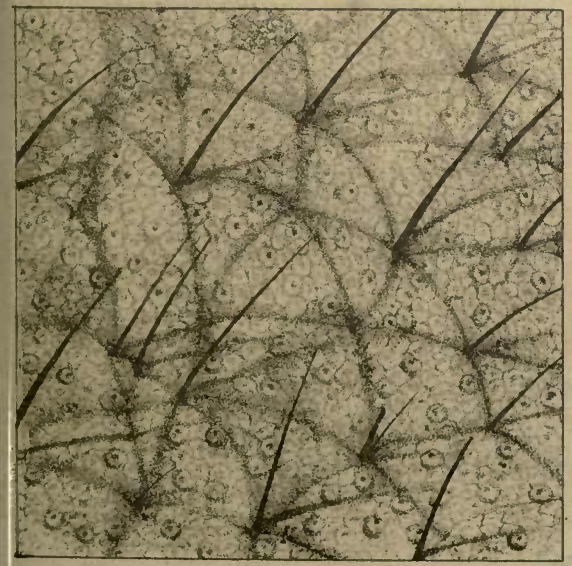

5
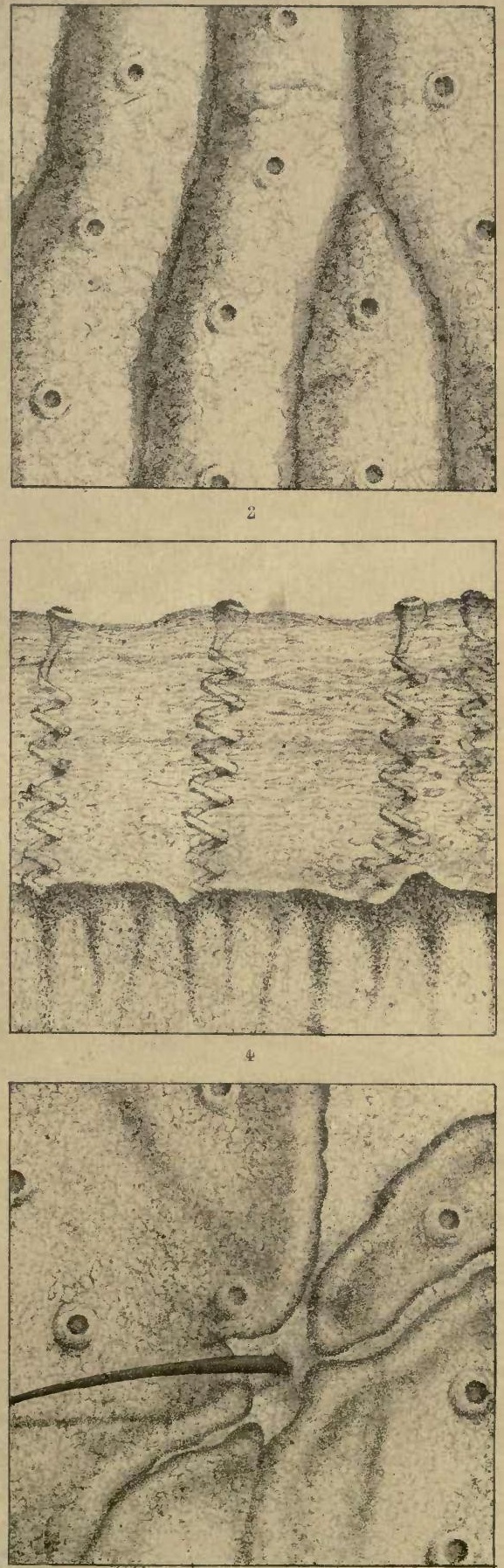

6 



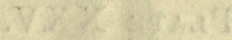

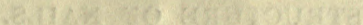

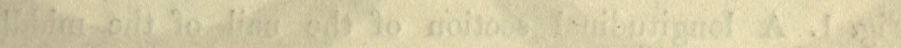

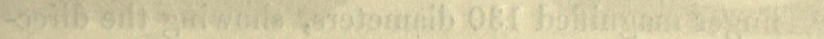

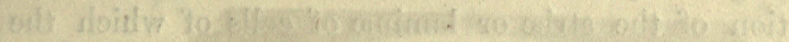

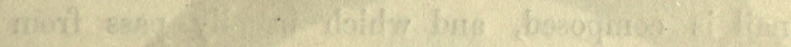

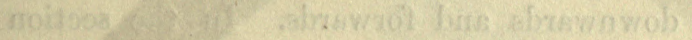

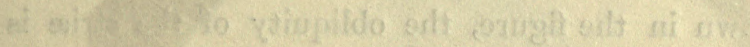

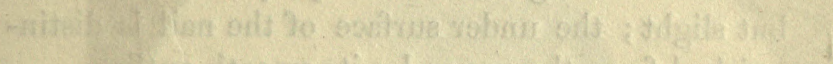

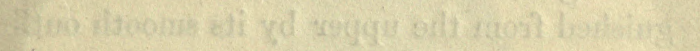

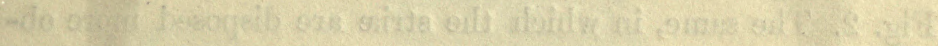

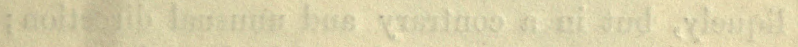

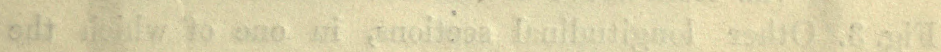

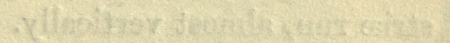

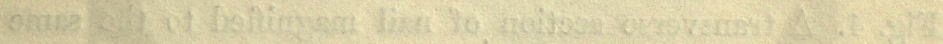

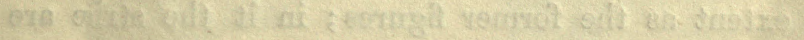

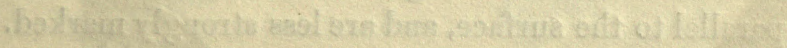

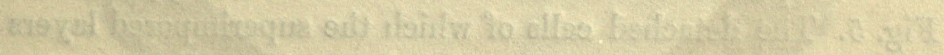

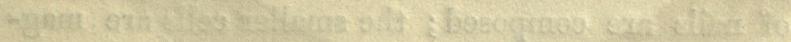

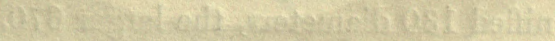

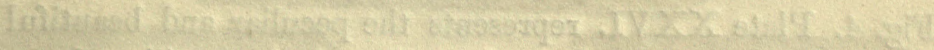

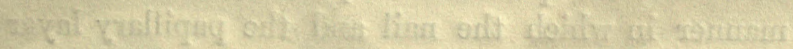

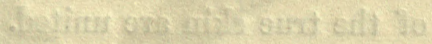




\section{Plate XXV. \\ STRUCTURE OF: NAILS.}

Fig. 1. A longitudinal section of the nail of the middle finger magnified 130 diameters, showing the direction of the strix or laminx of cells of which the nail is composed, and which usually pass from above downwards and forwards. In the section shown in the figure, the obliquity of the striæ is but slight; the under surface of the nail is distinguished from the upper by its smooth outline.

Fig. 2. The same, in which the striæ are disposed more obliquely, but in a contrary and unusual direction; viz. from above downwards and backwards.

Fig. 3. Other longitudinal sections, in one of which the striæ run, almost vertically.

Fig. 4. A transverse section of nail magnified to the same extent as the former figures; in it the striæ are parallel to the surface, and are less strongly marked.

Fig. 5. The detached cells of which the superimposed layers of nails are composed; the smaller cells are magnified 130 diameters, the larger 670 .

Fig. 4. Plate XXVI. represents the peculiar and beautiful manner in which the nail and the papillary layer of the true skin are united. 


$$
88
$$



explanation of the plates.

\section{Plate XXVI.}

STRUCTURE OF EPIDERMIS, \&c.

Fig. 1. A portion of epidermis taken from the back and outer part of the hand, magnified 100 diameters, and viewed on its upper surface, showing the elevations by which it is marked, and which are produced by the papillæ of the true skin.

Fig. 2. The same viewed on the under surface, showing the depressions occasioned by the papillæ. The number of apertures of the ducts of the sudoriferous and sebacious glands is, in reference to that of the papillæ, about one of the former to six or seven of the latter.

Fig. 3. A portion of epidermis magnified 100 diameters, removed from over the pubis of a woman, and displaying the apertures of the hair follicles, and the manner in which the hairs issue from them. Some of the follicles contain but a single hair, others two or even three: it is probable that this last is the normal number of hairs enclosed in each follicle wherever situated, but which in the adult is not generally encountered in consequence of the continual removal to which hairs are subject. It is about the apertures of the hair follicles that the scurf is formed, and concerning which a very erroneous notion prevails, viz, that it is constituted of desquimated epidermis. Scurf does not in the least exhibit the structure of epidermis, but simply consists of the inspissated secretion of the scbacious glands, and many of which, opening into the hair follicles, account for its collection around their orifices. 
Fig. 4. A transverse section of the nail of the middle toe of an adult magnified 100 diameters, showing its lamellated structure, and the mode of its connexion with the papillary layer of the dermis by mutually interlocking processes. This mode of union is excessively firm, and is precisely that employed by carpenters, and known by the appellation of "dovetailing."

Fig. 5. A portion of epidermis removed from the back of the neck by means of a blister, and magnified 670 diameters. The younger cells are seen to be filled with a straw-coloured fluid, the serum extracted through the agency of the vesicant.

Fig. 6. A. Some detached cells of epidermis, obtained by scraping the sole of the foot, magnified 670 diameters. Cells in a similar state exist beneath the nails, around the nipple, and on the surface of the body of new-born children where the creamy scum formed by them and intermingled with fatty matter poured out by the sebacious glands has been named Vernix caseosa. (See C.) - B. Cells of some magnified 130 diameters. - D. Cells of epithelium fiom the mouth of the Menobranchus lateralis : they are introduced for the purpose of showing the accuracy of the law of the relation in size of the several elements entering into the composition of the animal frame.-E. Two or three epithelial cells of the lateral ventricles of the brain. I have recently ascertained that the epithelium of the frontal sinuses is as stated, ciliated. I cannot help suspecting, however, that it is not in all cases so. No amount of care has succeeded in the detection of ciliary epithelium in the ventricles of the brain. The epidermis of tritons and frogs consists of hexagonal, translucent, and adherent cells, containing distinct granular nuclei. 


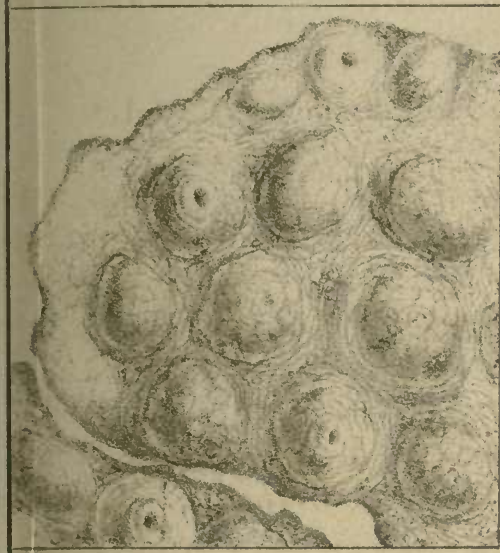

1

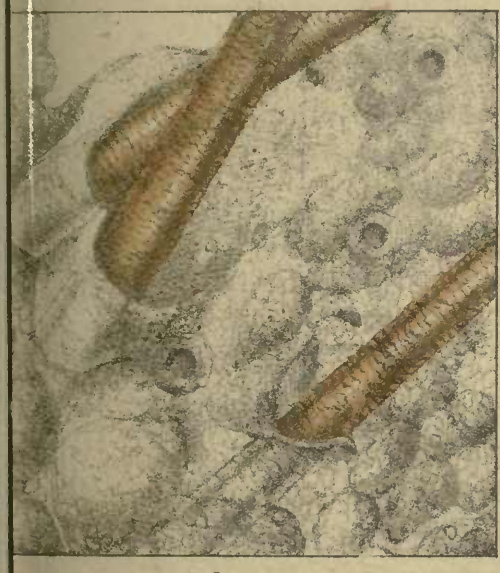

3

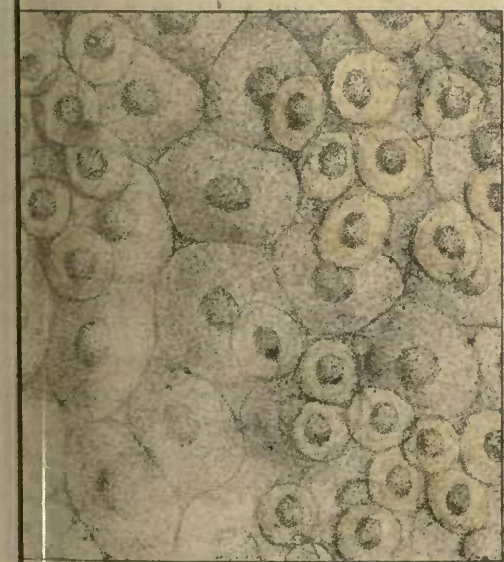

5

el or lith a na

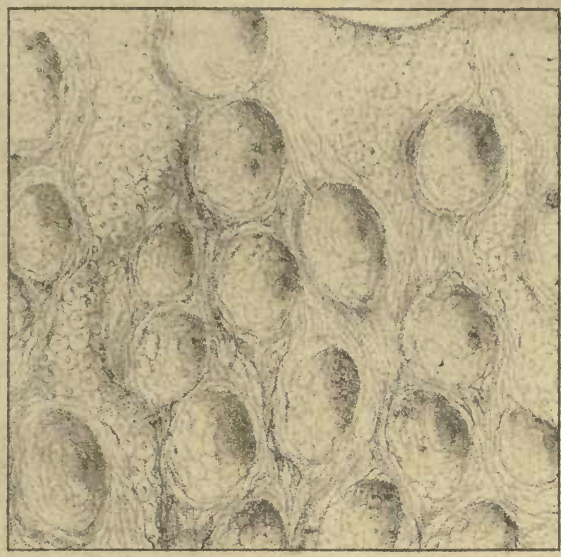

2

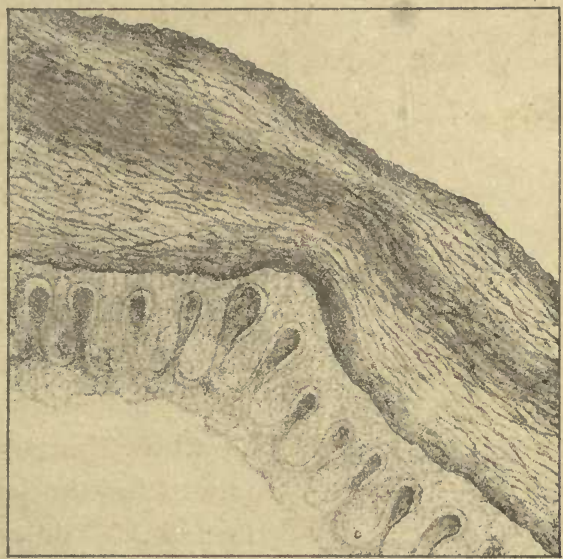

4

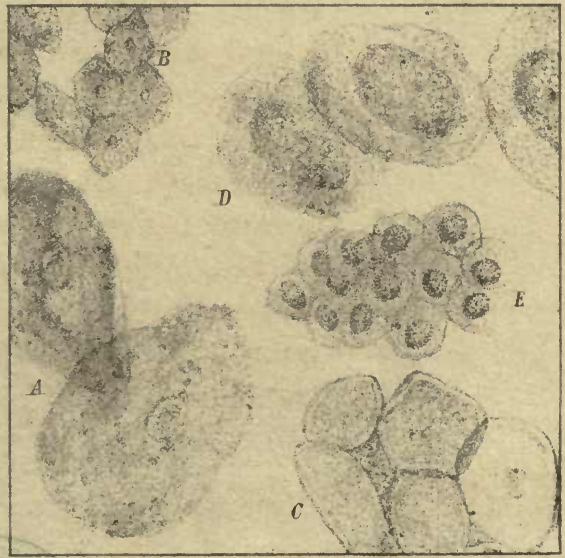



EXPLANATION OF THE PLATES.

\section{Plate XXVII.}

\section{PIGMENT GELLS.}

Fig. 1. Pigment cells and granules taken from off the inner surface of the choroid membrane of the human eye, magnified 670 diameters.

Fig. 2. The pigment cells of the inner surface of the choroid of the eye of the pig, magnified 350 diameters.

Fig. 3. Displays the linear and branched disposition of the stelliform pigment cells of the lamina fusca of the eye of the pig. A similar disposition of these cells also exists in the human eye, but in light-coloured eyes is not strongly marked: the branches commence on the posterior part of the lamina, miscalled fusca, since in some instances it is jetty black, are at first thick and closely arranged; as they approach the anterior part of the eye, however, they diminish in size, and are separated by distinct intervals. This figure is magnified 100 diameters.

Fig. 4. A. Human stelliform pigment cells of the eye, magnified 350 diameters. B. Pigment cells of the skin of the negro enlarged 670 diameters. C. Pigment cells from the lungs magnified to the same extent.

Fig. 5. A portion of the epidermis of the negro magnified 350 diameters, and, viewed on its under surface, the pigment cells are seen to be collected principally in the furrows which exist between the papillæ, the depressions produced by which are also represented in the figure.

Fig. 6. A portion of the epidermis removed from the areola around the nipple of a woman recently delivered, and also viewed upon its under surface. It is seen 
to differ solely from the epidermis of the negro in the smaller number of pigment cells contained in it. Obs. Pigment cells and granules frequently exist in the fibres of the external surface of the sclerotic of some animals, as the pig; and it is probable that in some instances they may be found in those of the eye of man. 




\section{Plate XXVIII.}

\section{STRUCTURE OF HAIR.}

Fig. 1. shows the structure and depth of implantation of the entire root of a hair of the scalp, magnified 130 diameters: it displays the two sheaths which include the stem, and its dilated extremity, the bulb, and which is seen to rest upon a distinct cellular vesicle; the outer sheath completely surrounds the base of the hair, and cuts it off from all direct vascular supply; the vessels, however, which nourish the hair are seen to ramify on the external surface of this sheath, which is also observed to be surrounded by fat vesicles, the root having passed through the thickness of the skin and imbedded itself in the subcutaneous and fatty cellular tissue.

Fig. 2. The root of a grey hair forcibly removed from the scalp; in this the outer sheath is seen to be broken off just above the place at which the stem begins to dilate into the bulb; a similar rupture almost invariably occurs in the outer sheath of all hairs, whether coloured or uncoloured, which are forcibly uprooted. The contrast between the coloured and the uncoloured hair is striking:

Fig. 3. The cells of which the outer sheath is composed: magnified 670 diameters.

Fig. 4. A portion of the inner sheath seen on its inner surface, and magnified 350 diameters; this is lined with a layer of elongated and nucleated cells; the outer portion of this sheath is distinctly fibrous, the fibres being formed out of the cells, the nuclei of which become absorbed: the inner surface also exhibits transverse markings, the impressions of the scales of the stem of the hair.

Fig. 5. Some of the pigment cells, of a multitude of which the bulb of the hair is composed: magnified 670 diameters. 


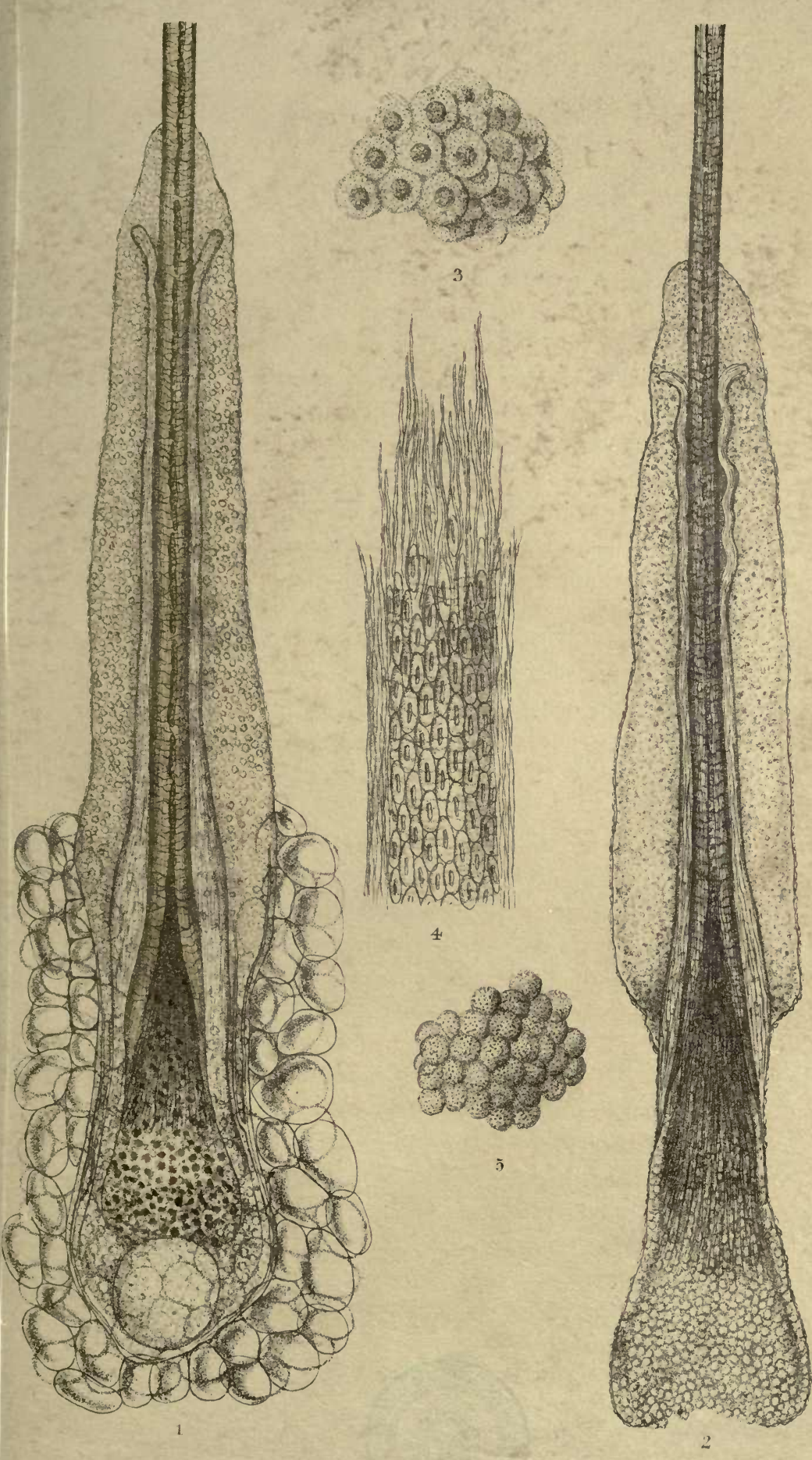





\section{Iis}

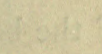

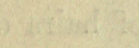

$\therefore$
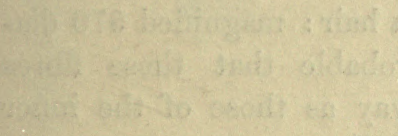

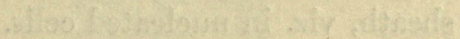

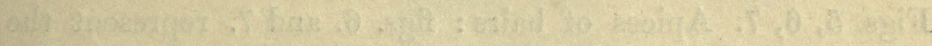

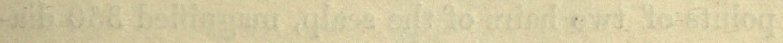

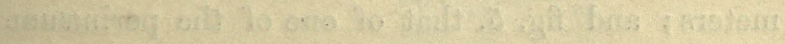

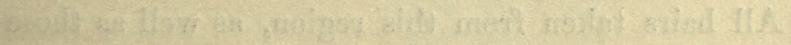

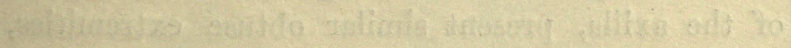

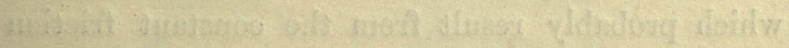

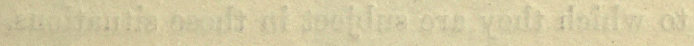

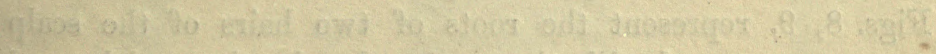

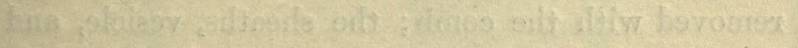

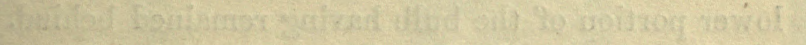

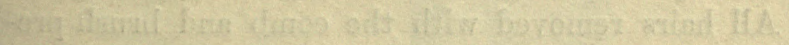

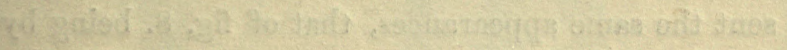

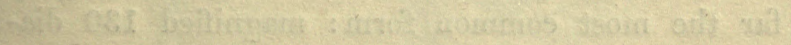

\section{-iciptyos}

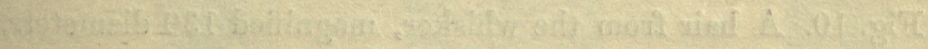

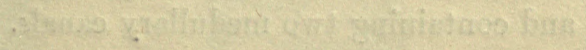




\section{Plate XXIX.}

\section{STRUCTURE OF HAIR.}

Fig. 1. A portion of the stem of a grey hair of the scalp, magnified 350 diameters, showing the medullary canal, the fibres of the stem, and the outer imbricated scales.

Figs. 2, 3. Transverse sections of hairs of the beard: magnified 130 diameters.

Fig. 4. The fibres of the stem of a hair: magnified 670 diameters. It is most probable that these fibres originate in the same way as those of the inner sheath, viz, in nucleated cells.

Figs. 5, 6, 7. Apices of hairs : figs. 6. and 7. represent the points of two hairs of the scalp, magnified 350 diameters; and fig. 5 . that of one of the perinæum. All hairs taken from this region, as well as those of the axilla, present similar obtuse extremities, which probably result from the constant friction to which they are subject in those situations.

Figs. 8, 9. represent the roots of two hairs of the scalp removed with the comb; the sheaths, vesicle, and lower portion of the bulb having remained behind. All hairs removed with the comb and brush present the same appearances, that of fig. 8 . being by far the most common form: magnified 130 diameters.

Fig. 10. A hair from the whisker, magnified 130 diameters, and containing two medullary canals. 



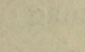




\section{Prate XXX. \\ STRUCTURE OF CARTILAGE.}

Fig. 1. A transverse section of the cartilage of a rib, magnified 350 diameters, showing the perichondrium and the compressed cells of the margin of the cartilage. It is most probable that it is in the space between the perichondrium and the external surface of the rib that the chief development of new cells takes place.

Fig. 2. A transverse section of the same, showing the parent cells, which are situated more deeply in the cartilage of the rib.

Fig. 3. A vertical section of the articular cartilage of the head of the first phalanx of the second finger, including also a portion of the bone, the cancelli of which contain numerous bone cells, and the spaces between which are filled with fat vesicles: magnified 130 diameters.

Fig. 4. A vertical section of the outer part of an intervertebral cartilage, including a portion of the bone. But few corpuscles, and these for the most part calcified, occur in the outer part of these cartilages: the medullary cells of the bone are seen to be filled with fat vesicles, granular nucleated cells, and effused blood corpuscles. It sometimes liappens that a layer of true articular cartilage is formed on the surface of the bone, and then the fibres of the fibro-cartilage take their origin from it, and not from the bone itself: 80 diameters. 


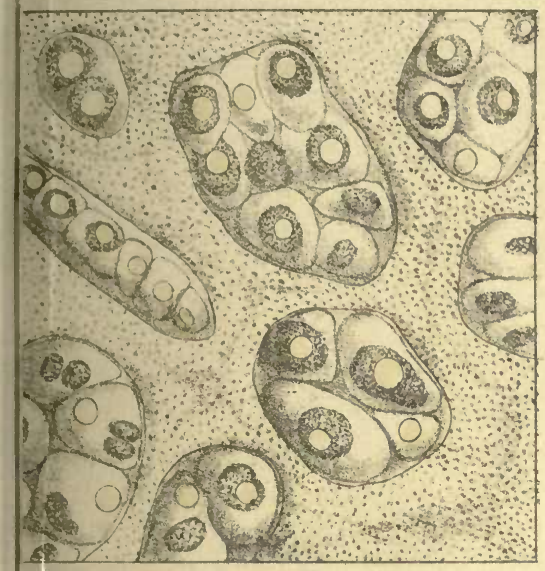

2

(1)

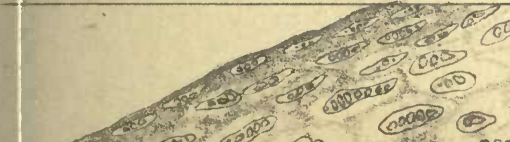

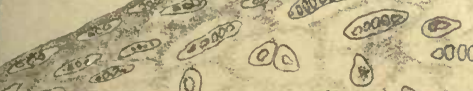

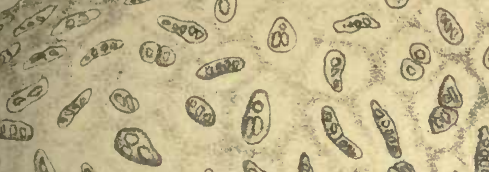
(1) की कि की की

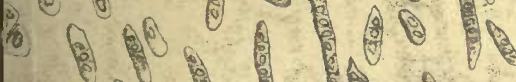

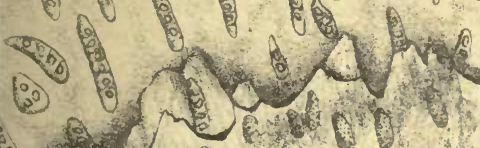

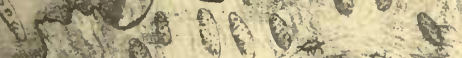

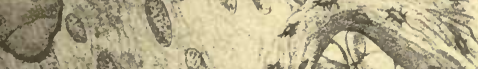

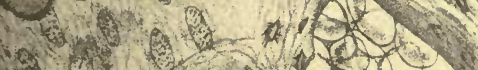

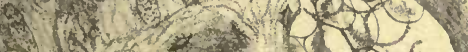

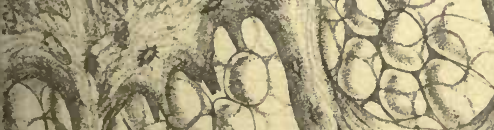

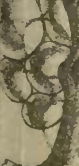
(6)

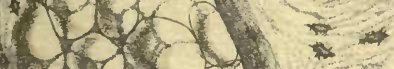
in $x$ in ats 4020 in

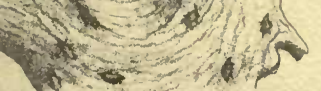
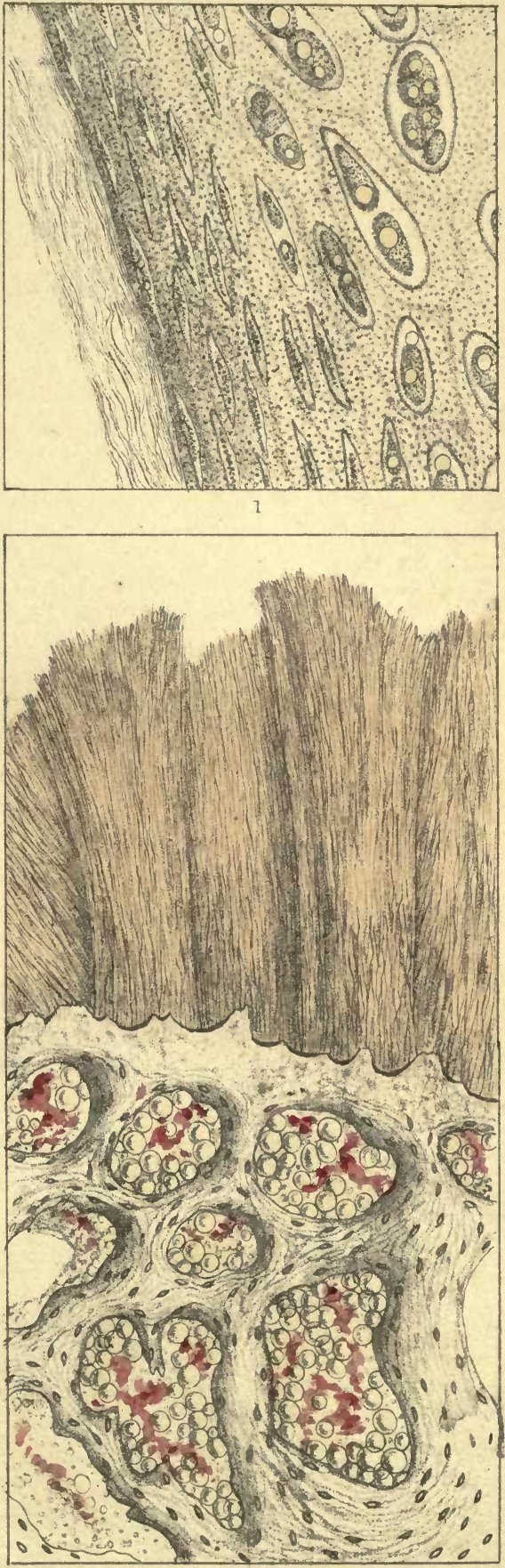




\title{
Plate XXXI.
}

\author{
STRUCTURE OF CARTILAGE.
}

Fig. 1. A thin transverse section of the cartilage of the concha of the ear: magnified 350 diameters.

Fig. 2. The cells of the centre of an intervertebral cartilage in the different stages of their development.

Fig. 3. A longitudinal section of the cartilage and bone of the rib of an adult, showing the mode of union between the two: magnified 130 diameters.

Fig. 4. A transverse section of one of the rings of the trachea; in these the cells are so closely aggregated that but little room is left between them for intercellular substance : 350 diameters.

Fig. 5. A transverse section of the thyroid cartilage of a young man eighteen years of age, in which fibres analogous to those of the fibro-cartilages have made their appearance: 130 diameters. 

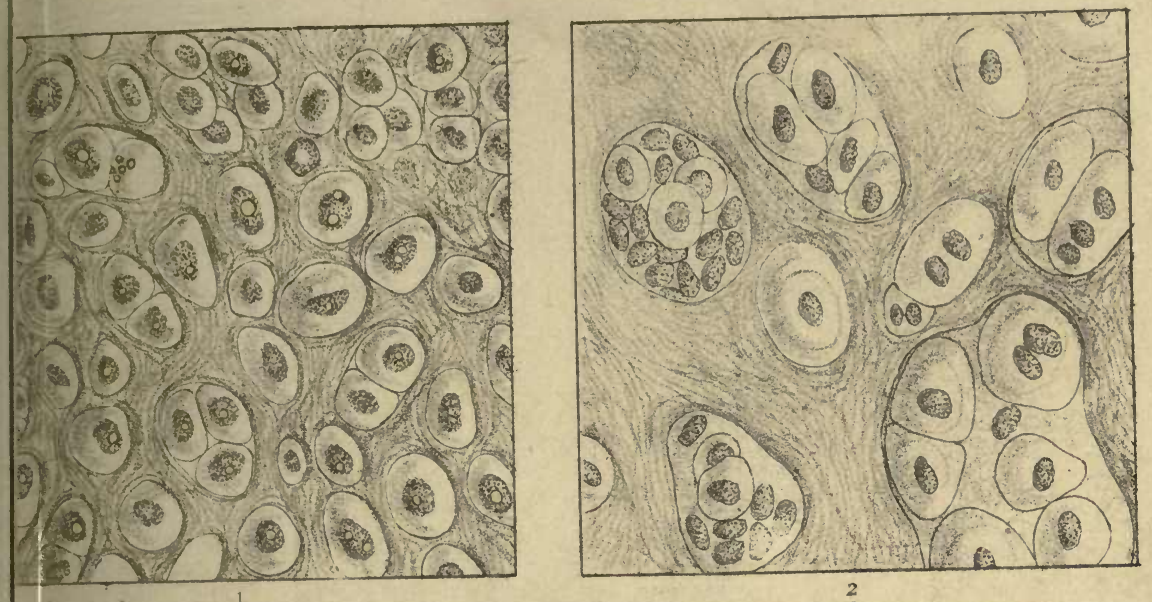

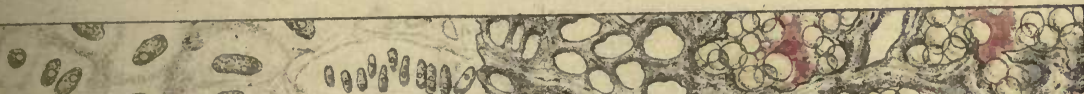
1.

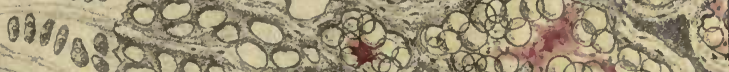
- - - अ5

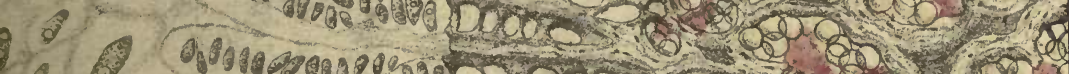

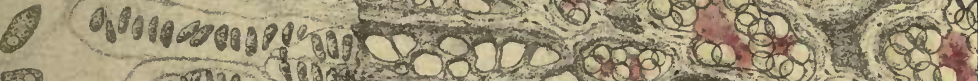

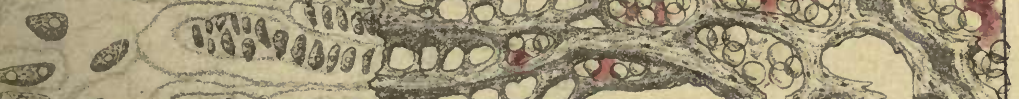

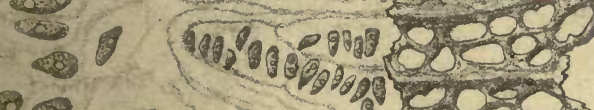
- 2 m - 0 .
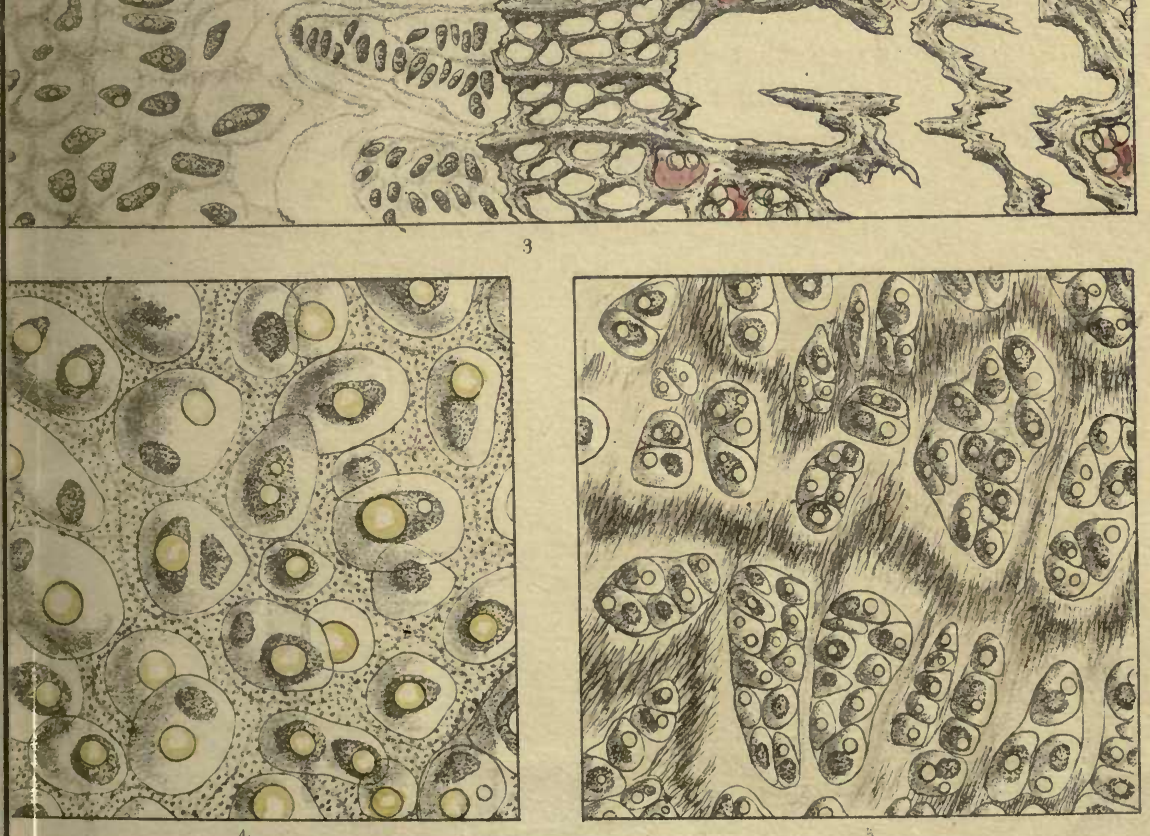


\section{Plate XXXII.}

\section{STRUCTURE OF BONE.}

Fig. 1: A transverse section of ulna, magnified 60 diameters, showing the Haversian canals, the difference in the size of those situated on the outer and inner portions of the section, the systems of the lamellæ by which each canal is surrounded, and the bone cells placed between the lamellæ.

Fig. 2. Cross section of Haversian canals, magnified 220 diameters, showing the lamellæ and the bone cells with their anastamosing canaliculi more distinctly.

Fig. 3. The same, still more highly magnified, viz. 670 diameters.

Fig. 4. Longitudinal section of long bone, magnified about 40 diameters, showing the Haversian canals, seen lengthways, the direction of the lamellæ and the bone cells. 
(19) Con (m, in

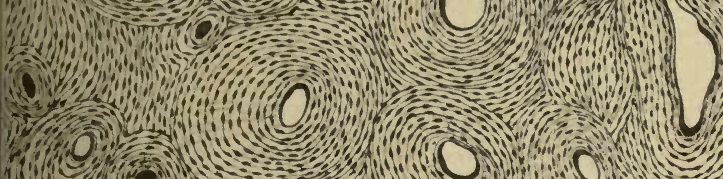

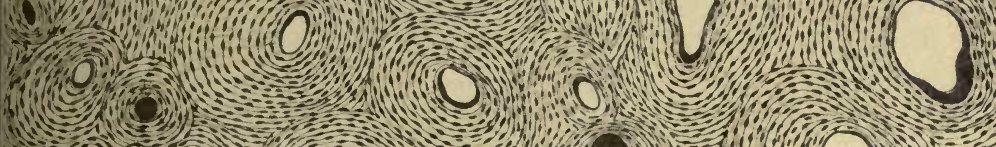

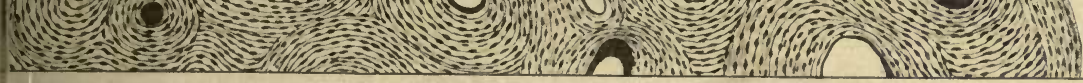

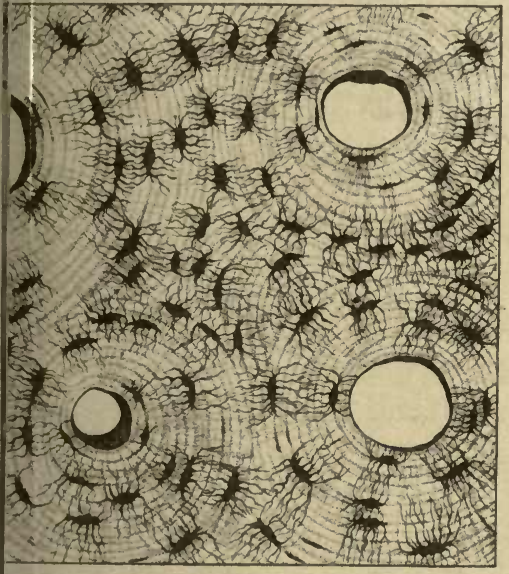

2

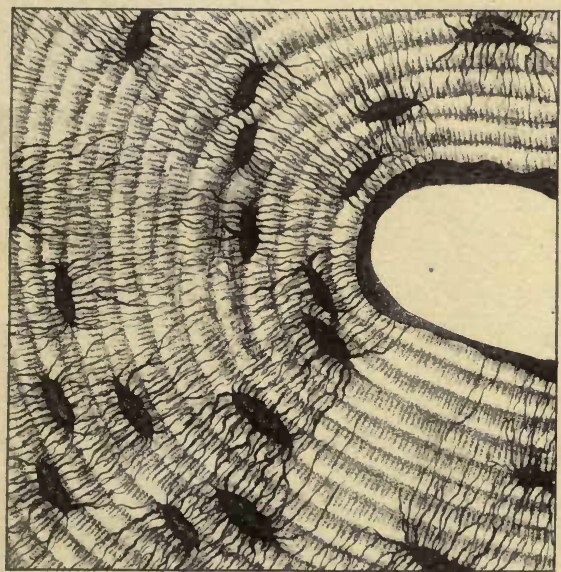

3

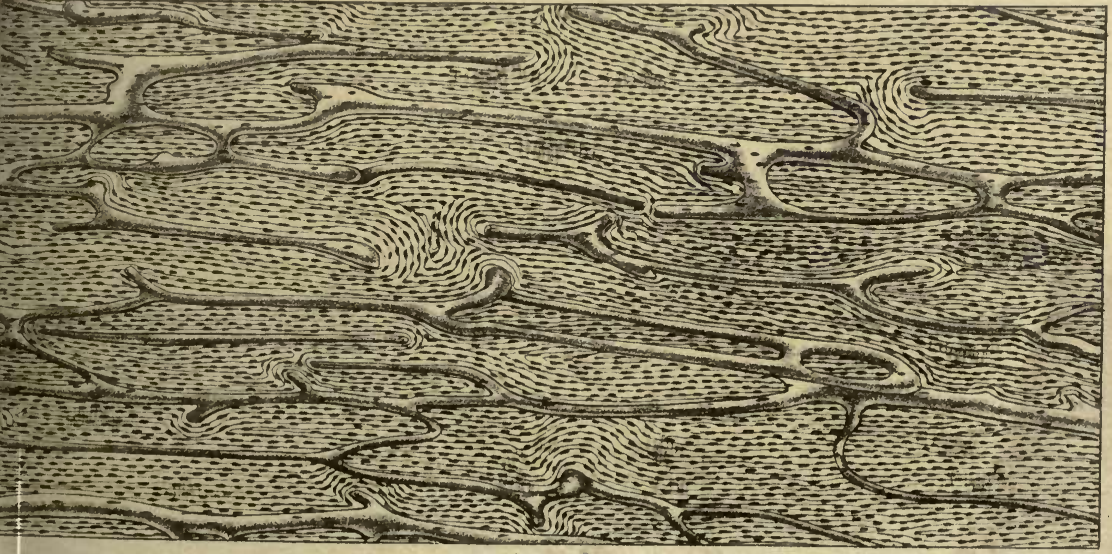






\section{Plate XXXIII.}

STRUCTURE AND DEVELOPMENT OF BONE.

Fig. 1. Parietal bone of human foetus, aged about two months, magnified 30 diameters.

Fig. 2. A portion of same, magnified 60 diameters, showing the bone cells in process of development, some of which are seen lying loose in the spaces between the speculæ, and which were destined, eventually, to become included in the ossific deposition.

Fig. 3. Speculæ of bone of a foetal humerus, showing the gradual deposition of the bony matter in the meshes of fibrous tissue, and altogether independently of cartilage, magnified 350 diameters.

Fig. 4. Lamina of a long bone, magnified 500 diameters, drawn from a preparation kindly placed at the author's disposal by Dr. Sharpey, by whom the structure figured was first described.

Fig. 5. Cancelli of one of the long bones of a human foetus, magnified 350 diameters, showing the vast numbers of granular corpuscles which the medullary cells of bone of every age contain, but which are especially abundant in foetal bones; the larger cells are magnified 750 diameters.

Fig. 6. Cross section of the femur of a pigeon fed for 24 hours upon madder. This drawing was made from a beautiful preparation belonging to Mr. Tomes, and lent me by that gentleman. Magnified 220 diameters. 


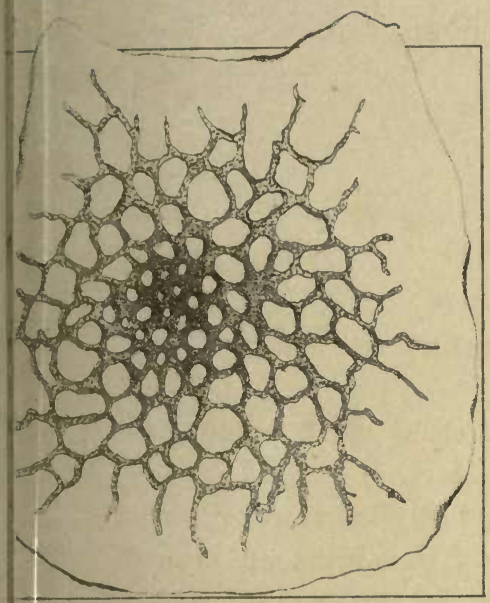

1

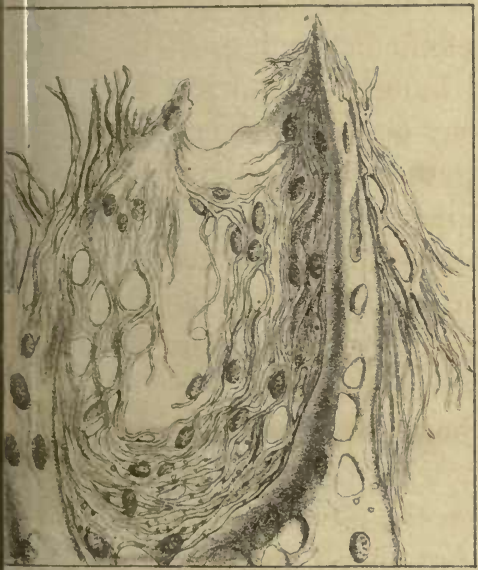

3

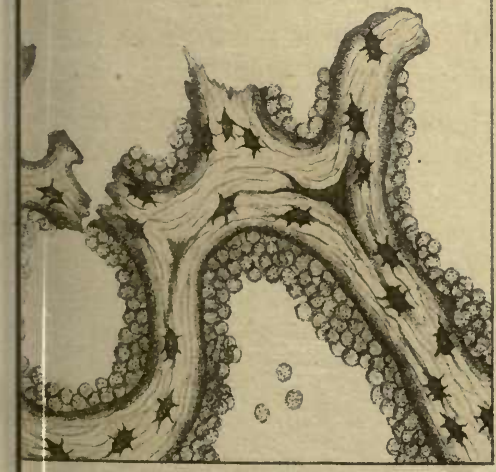

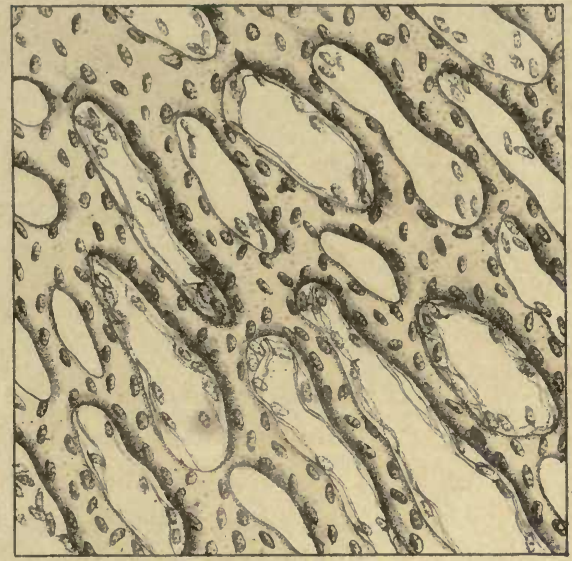

2

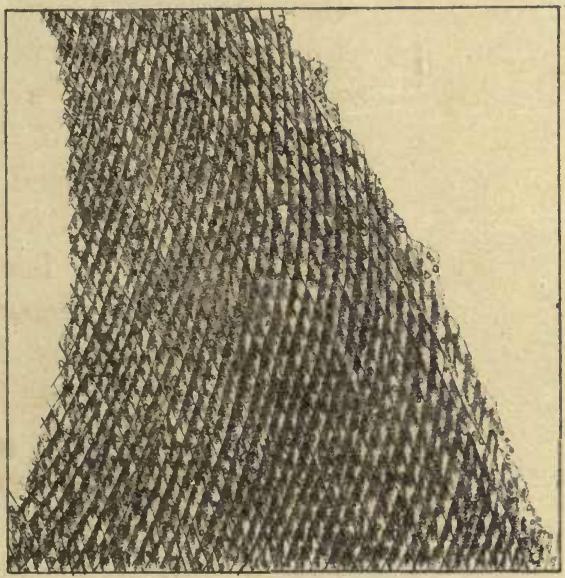

4

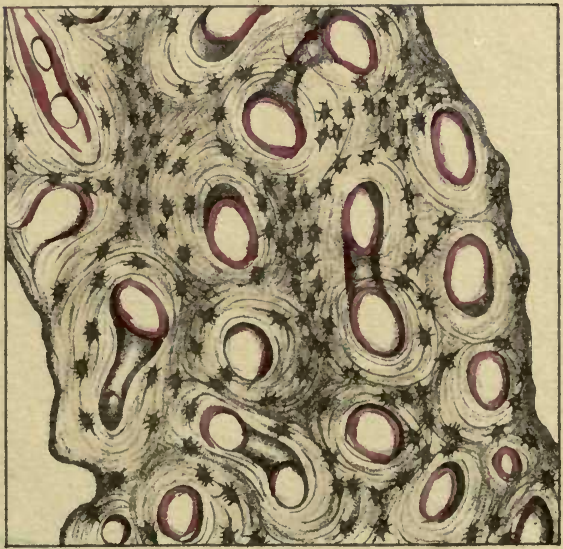

6. 




\section{Plate XXXIV:}

\section{DEVELOYMENT OF BONE.}

Fig. 1. Longitudinal section of the epiphysis and a portion of the shaft of a fotal femur at the ninth month, magnified 100 diameters, and showing the columnar arrangement of the cartilage cells, together with the increased size of the lower cells, and the invading spiculæ of the newly formed bone.

Fig. 2. Transverse section of primary cancelli, magnified 350 diameters, showing the included nuclei of cartilage cells contained in the medullary cells or spaces.

Fig. 3. Transverse section of primary cancelli, magnified to the same extent as the last figure, in a more advanced stage of their formation, many of the first formed cancelli or septa having been absorbed as well as the cell wall of the cartilage corpuscles themselves.

Fig. 4. Longitudinal section of the epiphysis and a portion of the shaft of a foetal femur at the ninth month, magnified 350 diameters. 

EXILANATION OF THE PIATES.

\section{Plate XXXV.}

DEVELOPMENT OF IBONE.

Fig. 1. A transverse section of the cartilaginous epiphysis of the lower end of humerus, magnified 30 diameters, showing the apertures of the canals by which it is traversed.

Fig. 2. The same in connection with the bone: in this figure it will be observed that there are fewer canals, that these are of larger calibre, and that the cartilage cells are disposed around them in a radiate manner in groups.

Fig. 3. One of the apertures of the canal more highly magnified, 330 diameters, showing more clearly the arrangement of the cells around it, the contents of the canal being granular corpuscles and bloodvessels, as well as the fact that the intercellular spaces nearest to the opening are the last to become converted into bone: in most of the medullary spaces of the second tier the granular corpuscles have already made their appearance, the cartilage cells having been removed by absorption.

Fig. 4. The blood-vessels of the medullary cells of a young bone near the epiphysis injected. For the specimen from which this figure was drawn $I$ am indebtel to the kindness of Mr. Quekett of the Royal College of Surgeons.

Fig. 5. Transverse section of the shaft of a foctal long bone, displaying the fact that in foctal bones there are no Haversian canals, such entirely consisting of medullary cells. 
Fig. 6. Transverse section of the rib of an adult, magnified 130 diameters, passing obliquely through the junction of the cartilage with the bone: in the upper part of the figure the cancelli are seen, including the terminal portions of the lowest tier of cartilage cells. 


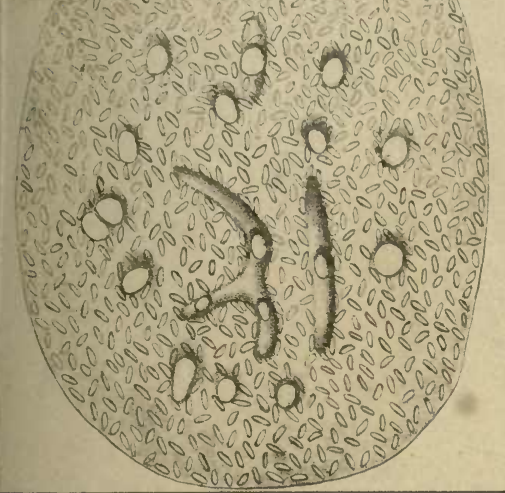

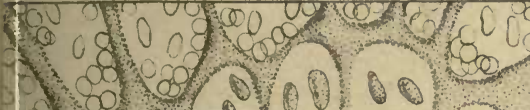
10 0 O 0 - 10 o 10 $-10.00 \%$ - $c$ -

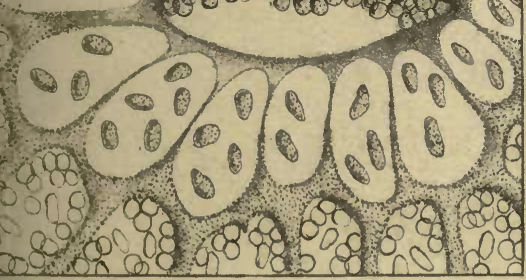
3

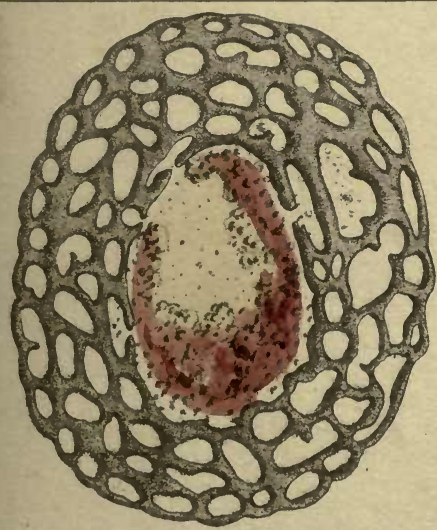

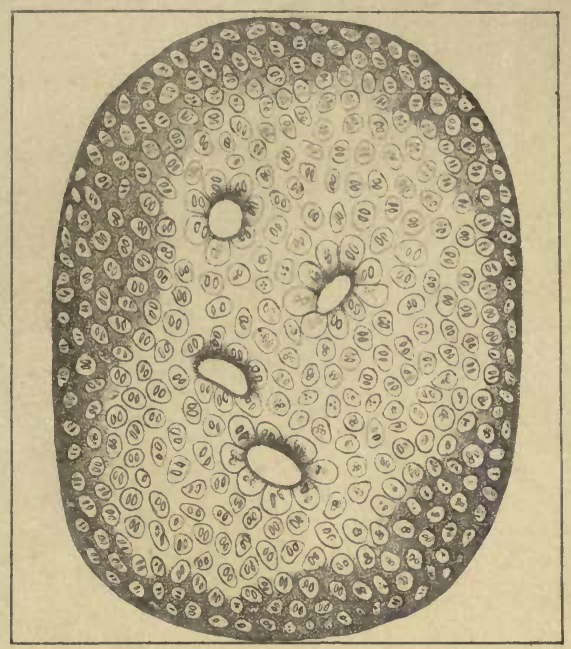

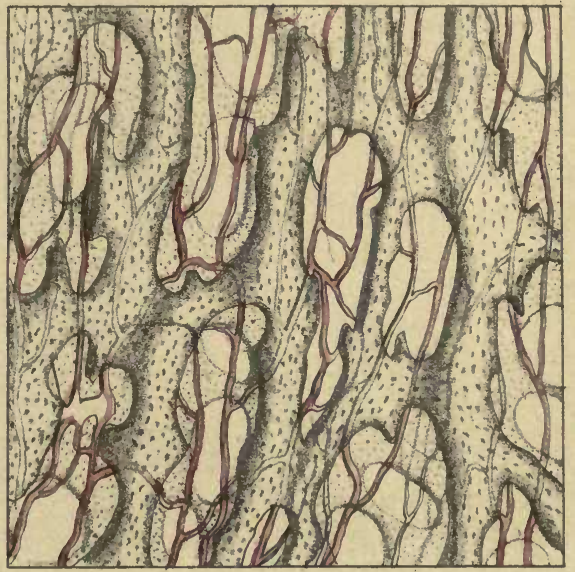

4

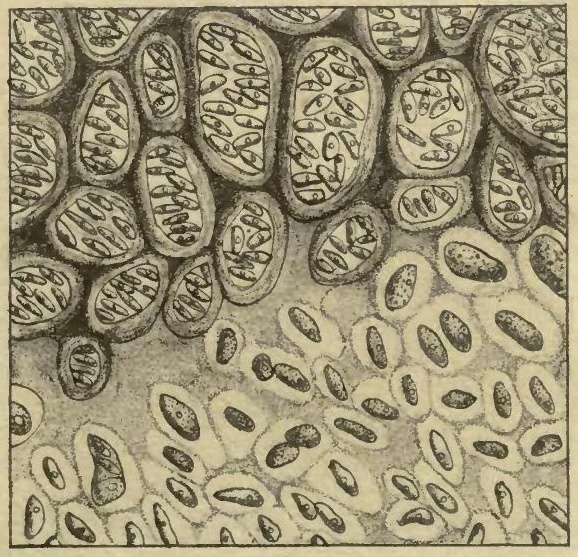





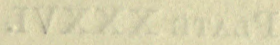

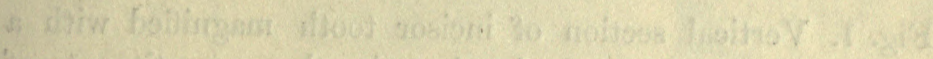

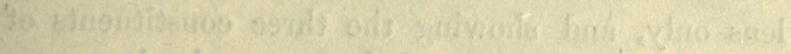

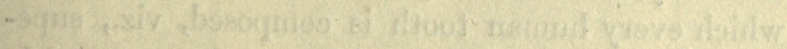

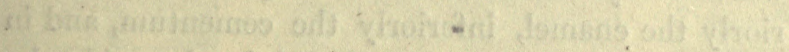

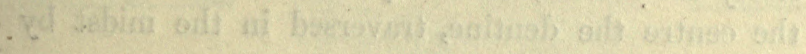

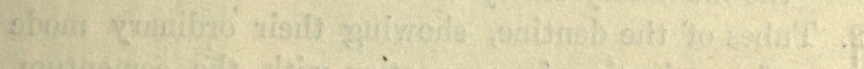

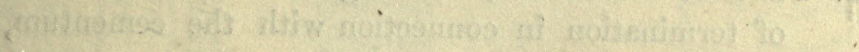

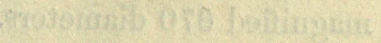

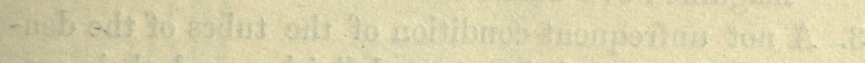

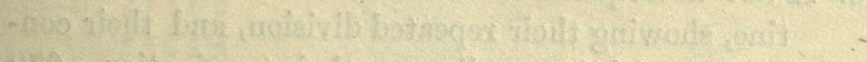

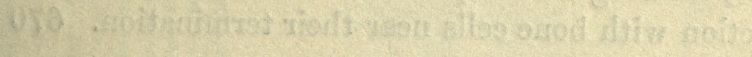

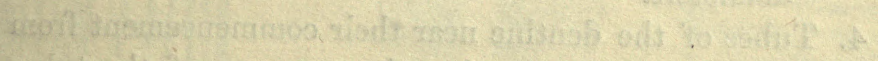

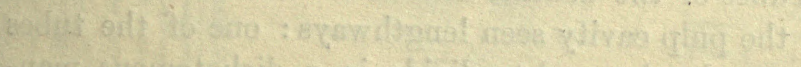

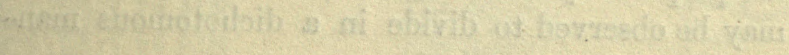

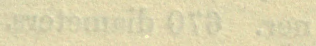

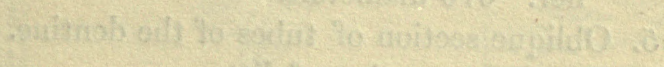

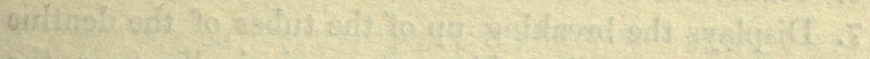

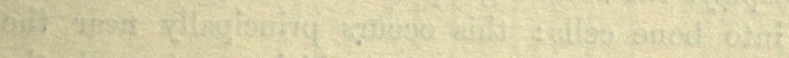

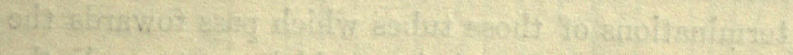

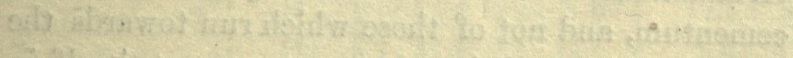

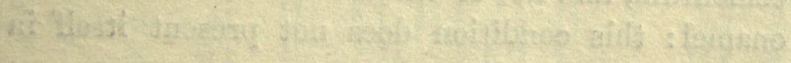

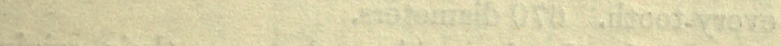

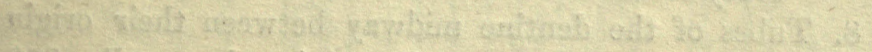

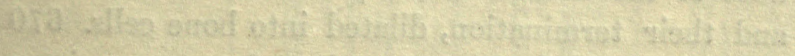

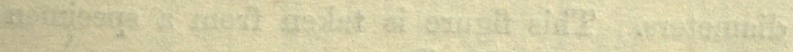

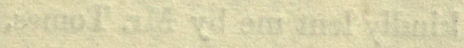




\section{Plate XXXVI.}

STRUCTURE OF TEETH.

Fig. 1. Vertical section of incisor tooth magnified with a lens only, and showing the three constituents of which every human tooth is composed, viz., superiorly the enamel, inferiorly the cementum, and in the centre the dentine, traversed in the midst by the medullary cavity.

2. Tubes of the dentine, showing their ordinary mode of termination in connection with the cementum, magnified 670 diameters.

3. A not unfrequent condition of the tubes of the dentine, showing their repeated division, and their connection with bone cells near their termination. 670 diameters.

4. Tubes of the dentine near their commencement from the pulp cavity seen lengthways: one of the tubes may be observed to divide in a dichotomous manner. 670 diameters.

5. Oblique section of tubes of the dentine.

6. Transverse section of ditto.

7. Displays the breaking up of the tubes of the dentine into bone cells: this occurs principally near the terminations of those tubes which pass towards the cementum, and not of those which run towards the enamel: this condition does not present itself in every tooth. 670 diameters.

8. Tubes of the dentine midway between their origin and their termination, dilated into bone cells. 670 diameters. This figure is taken from a specimen kindly lent me by Mr. Tomes. 

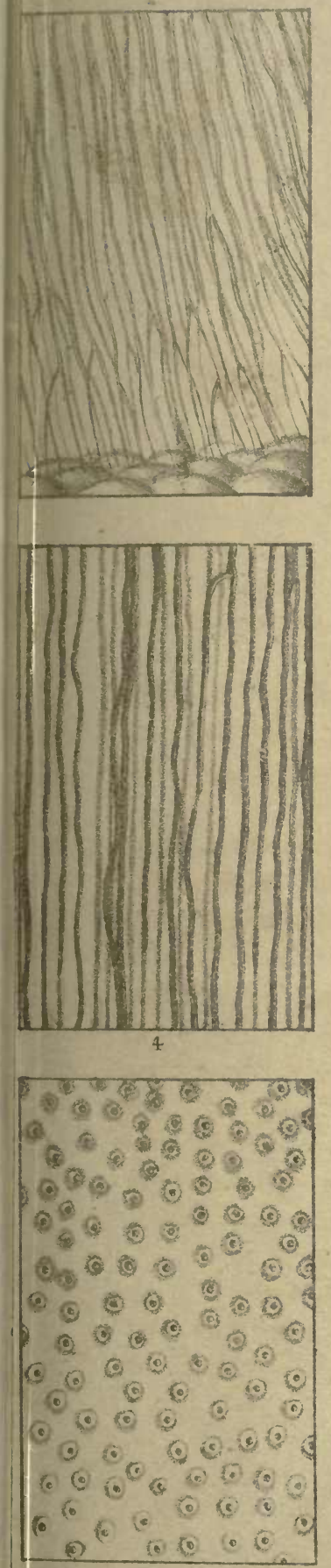
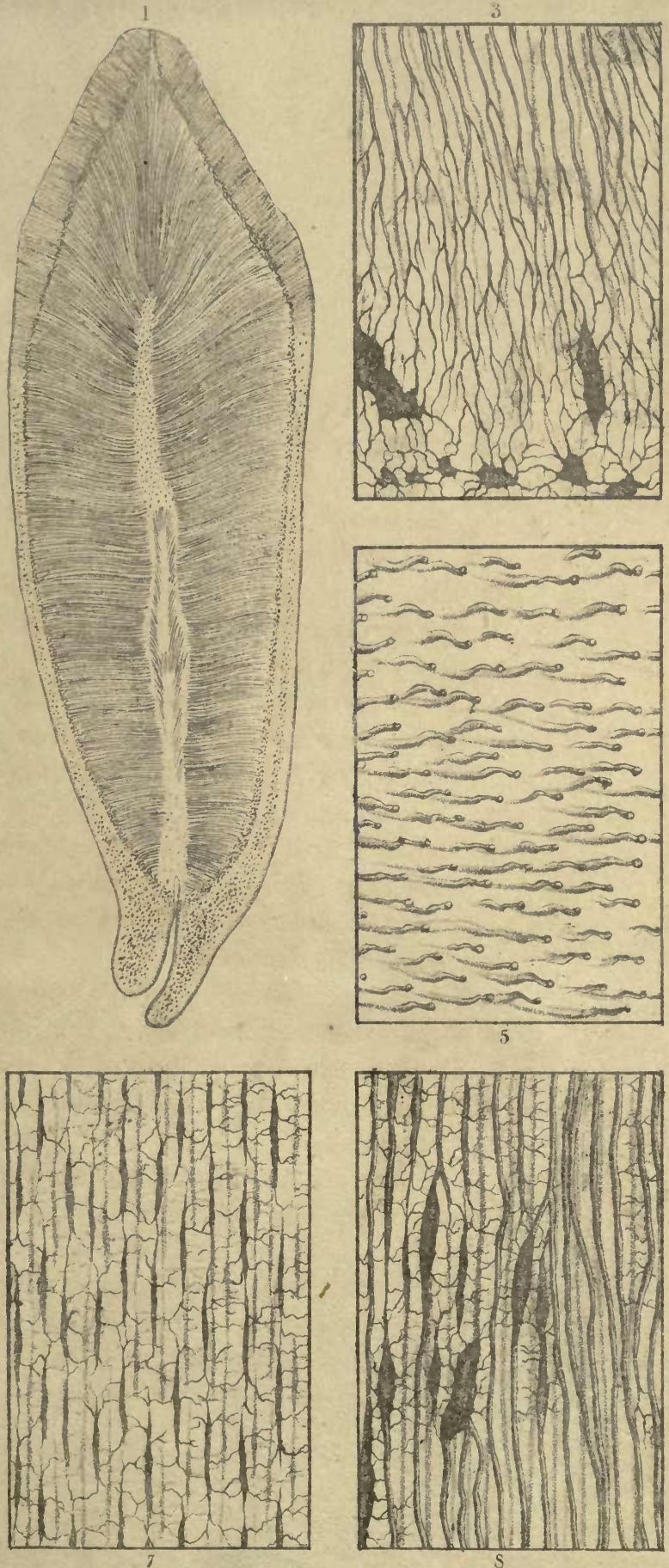



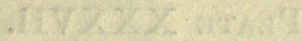

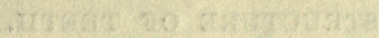

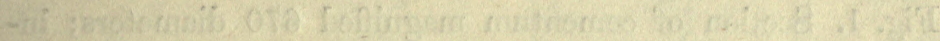

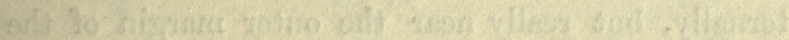

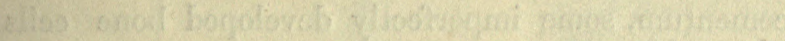

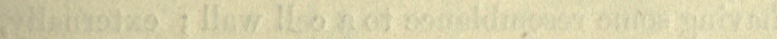

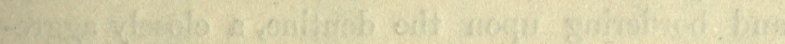

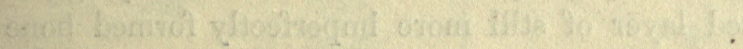

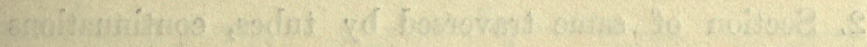

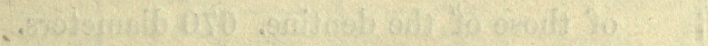

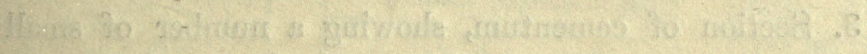

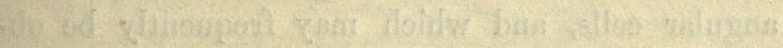

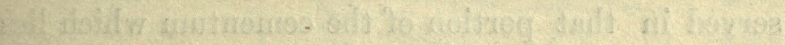

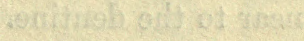

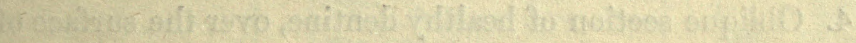

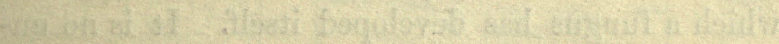

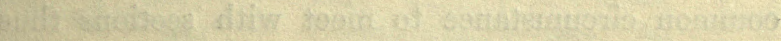

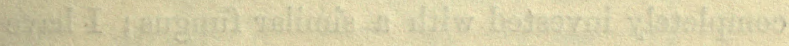

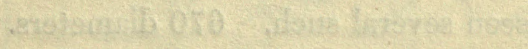

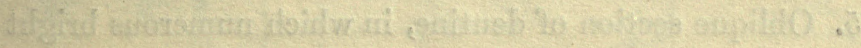

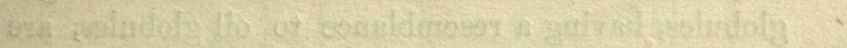

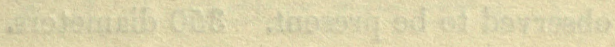

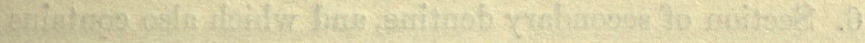

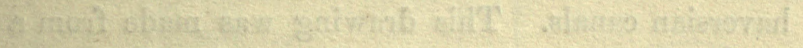

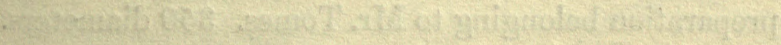

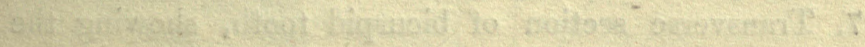

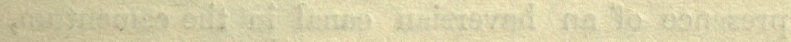

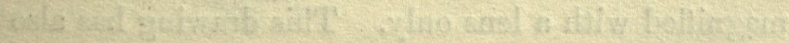
(a)

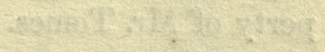




\section{Plate XXXVII.}

\section{STRUCTURE OF TEETH.}

Fig. 1. Section of cementum magnified 670 diameters; internally, but really near the outer margin of the cementum, some imperfectly developed bone cells may be observed, each surrounded by a clear space, having some resemblance to a cell wall ; externally, and bordering upon the dentine, a closely aggregated layer of still more imperfectly formed bone cells are seen.

2. Section of same traversed by tubes, continuations of those of the dentine. 670 diameters.

3. Section of cementum, showing a number of small angular cells, and which may frequently be observed in that portion of the cementum which lies near to the dentine.

4. Oblique section of healthy dentine, over the surface of which a fungus has developed itself. It is no uncommon circumstance to meet with sections thus completely invested with a similar fungus; I have seen several such. 670 diameters.

5. Oblique section of dentine, in which numerous bright globules, having a resemblance to oil globules, are observed to be present. 350 diameters.

6. Section of secondary dentine, and which also contains haversian canals. This drawing was made from a preparation belonging to $\mathrm{Mr}$. Tomes. 350 diameters.

7. Transverse section of bicuspid tooth, showing the presence of an haversian canal in the cementum, magnified with a lens only. This drawing has also been made from an interesting preparation, the property of Mr. Tomes: 

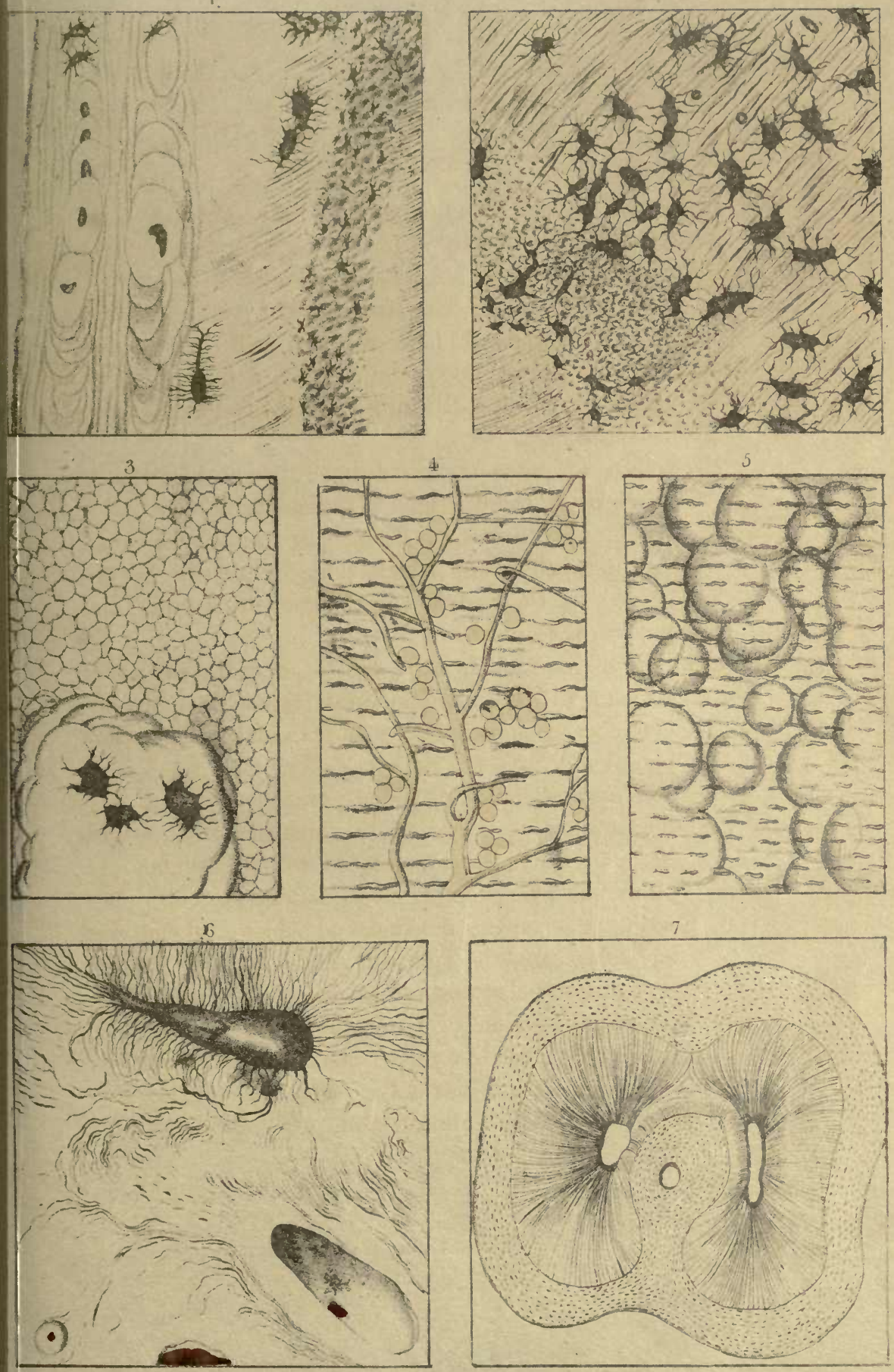



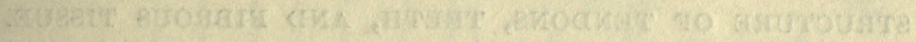

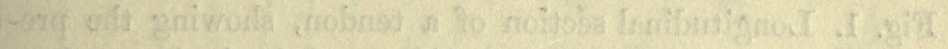

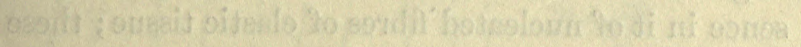

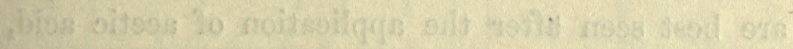

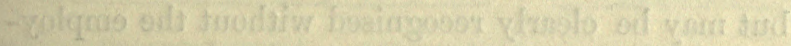

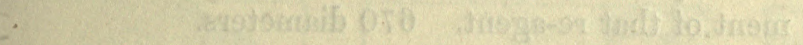

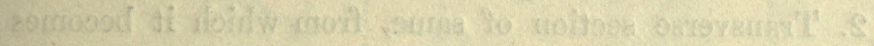

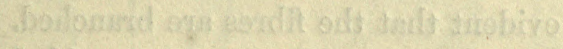

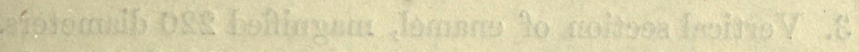

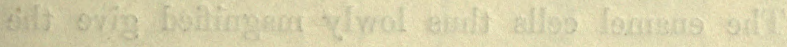

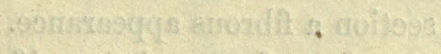

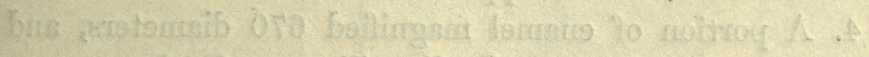

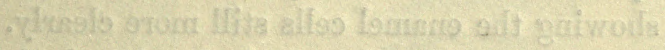

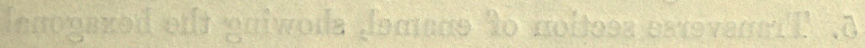

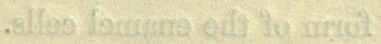

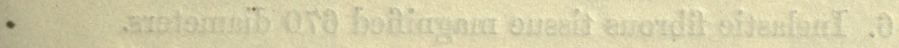

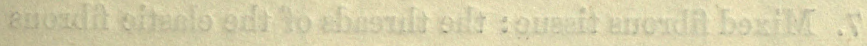

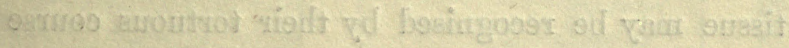
- smituro baritob sqong birs 


\section{Plate XXXIX.}

STRUCTURE OF TENDONS, TEETH, AND FIBROUS TISSUE.

Fig. 1. Longitudinal section of a tendon, showing the presence in it of nucleated fibres of elastic tissue; these are best seen after the application of acetic acid, but may be clearly recognised without the employment of that re-agent. 670 diameters.

2. Transverse section of same, from which it becomes evident that the fibres are branched.

3. Vertical section of enamel, magnified 220 diameters. The enamel cells thus lowly magnified give the section a fibrous appearance.

4. A portion of enamel magnified 670 diameters, and showing the enamel cells still more clearly.

5. Transverse section of enamel, showing the hexagonal form of the enamel cells.

6. Inelastic fibrous tissue magnified 670 diameters.

7. Mixed fibrous tissue: the threads of the elastic fibrous tissue may be recognised by their tortuous course and more defined outline. 

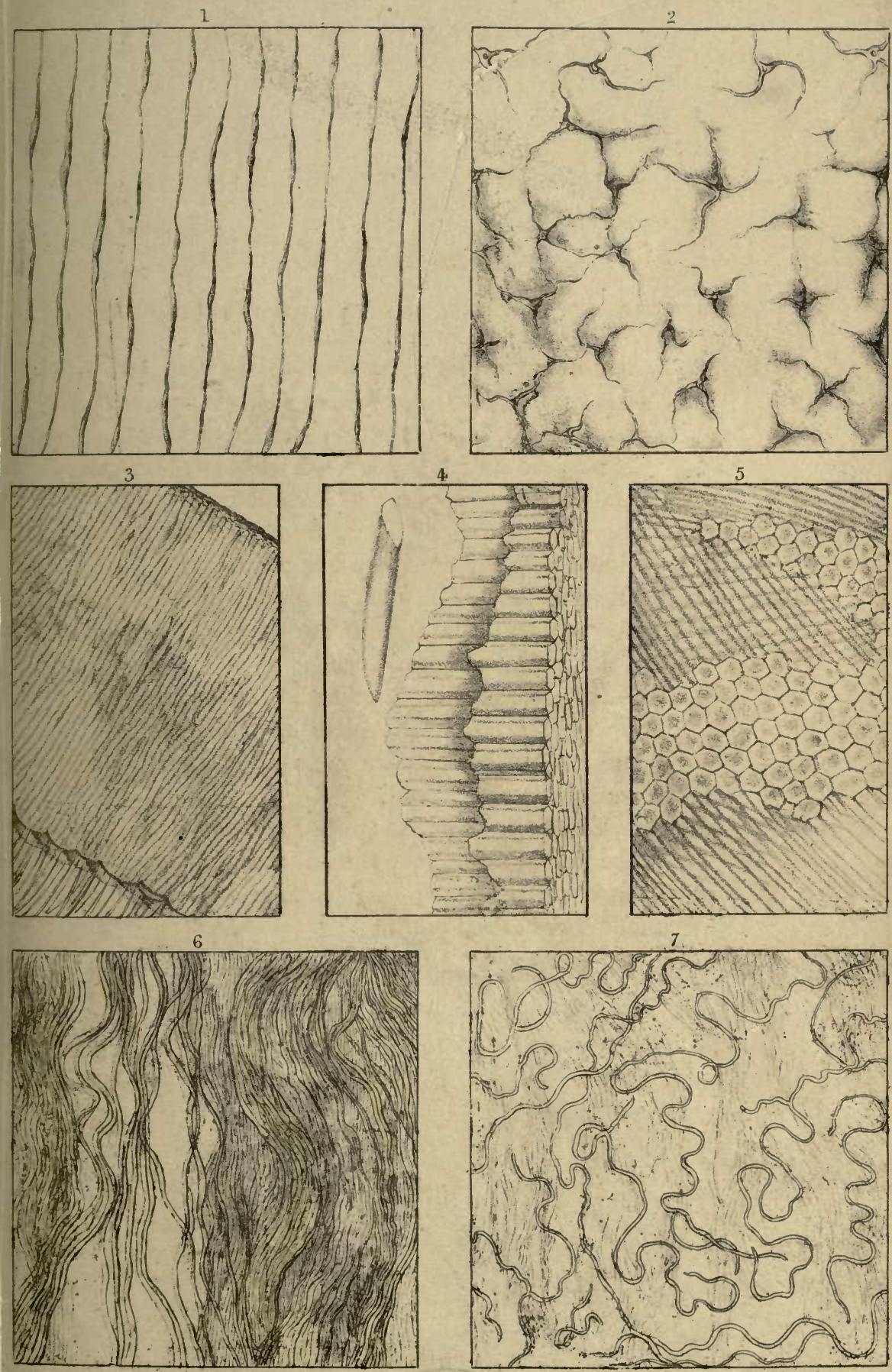



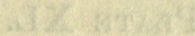

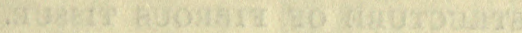

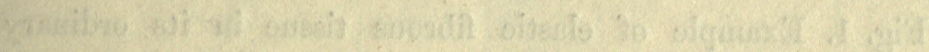

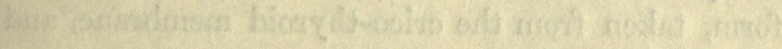

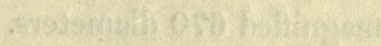

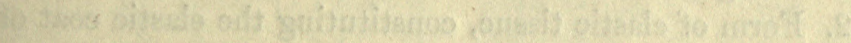

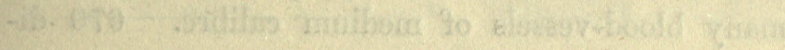

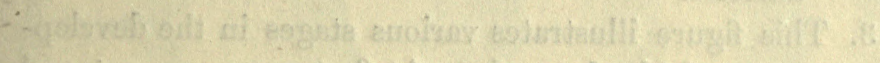

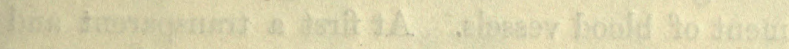

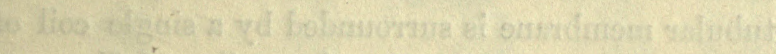

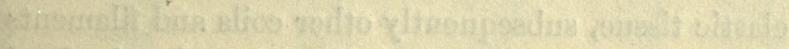

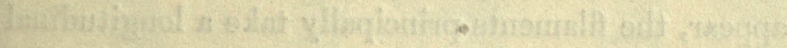

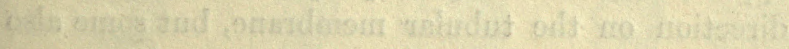

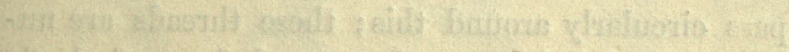

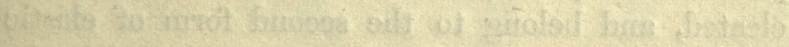

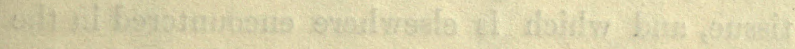

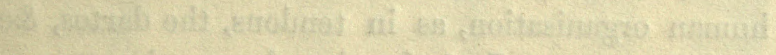

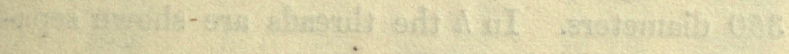
Nitionstis

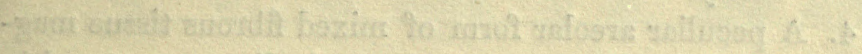
2.7.

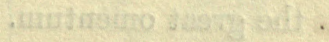

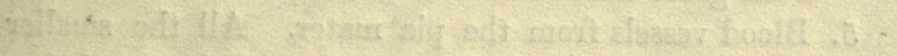

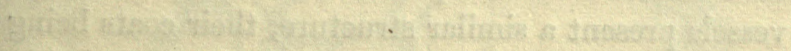

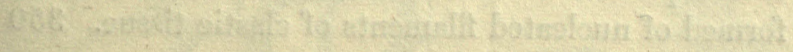

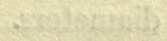




\section{Plate XL.}

STRUCTURE OF FIBROUS TISSUE.

Fig. 1. Example of elastic fibrous tissue in its ordinary form, taken from the crico-thyroid membrane, and magnified 670 diameters.

2. Form of elastic tissue, constituting the elastic coat of many blood-vessels of medium calibre. 670 diameters.

3. This figure illustrates various stages in the development of blood vessels. At first a transparent and tubular membrane is surrounded by a single coil of elastic tissue, subsequently other coils and filaments appear, the filaments principally take a longitudinal direction on the tubular membrane, but some also pass circularly around this; these threads are nucleated, and belong to the second form of elastic tissue, and which is elsewhere encountered in the human organisation, as in tendons, the dartos, \&c. 350 diameters. In $h$ the threads are shown separately.

4. A peculiar areolar form of mixed fibrous tissue magnified 130 diameters, and principally encountered in the great omentum.

5. Blood vessels from the pia mater. All the smaller vessels present a similar structure, their coats being formed of nucleated filaments of elastic tissue. 350 diameters. 

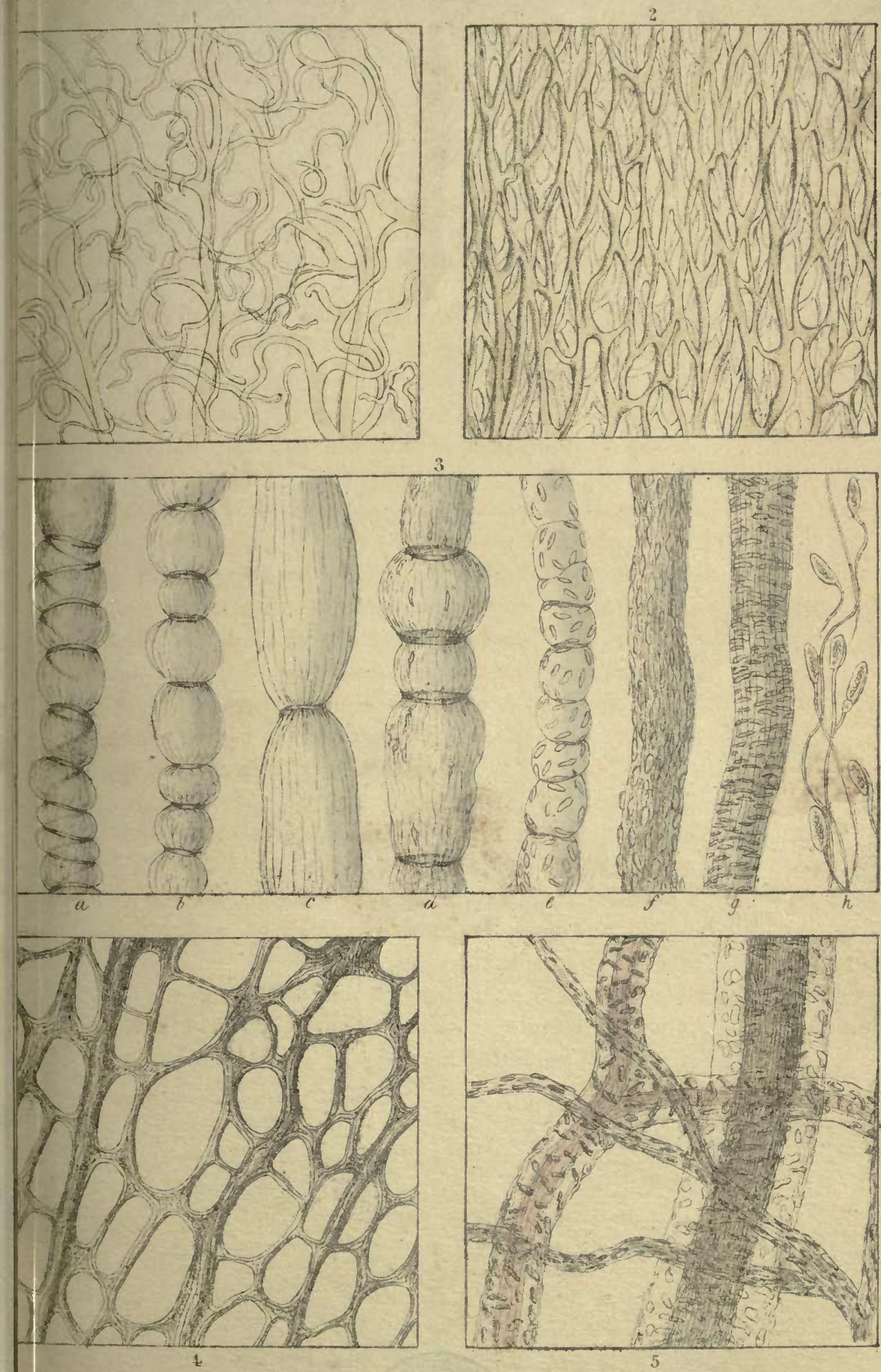

3

.





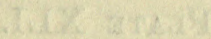

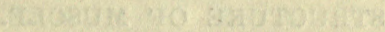

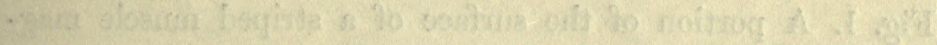

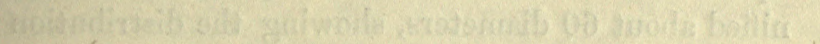

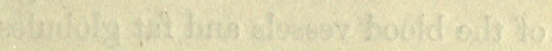

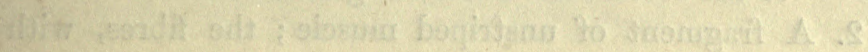

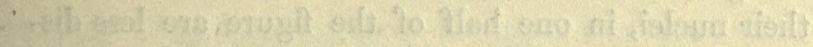

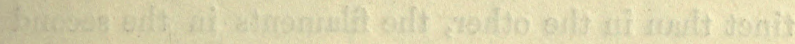

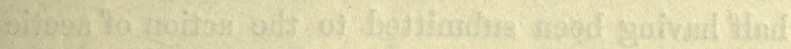

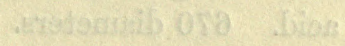

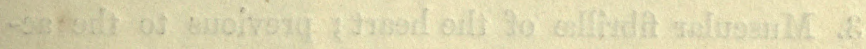

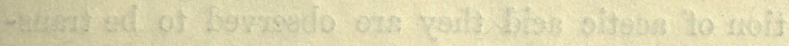

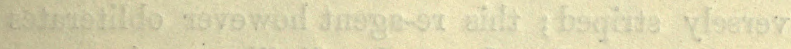

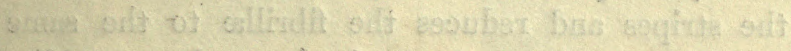

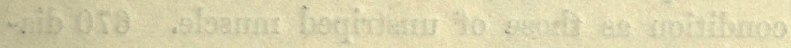

$$
\text { vetossis: }
$$

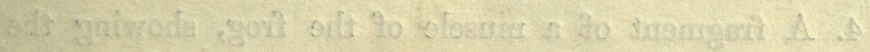

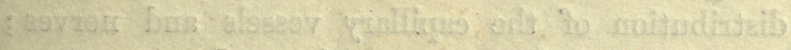

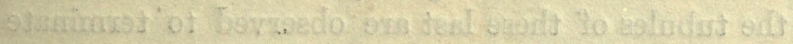

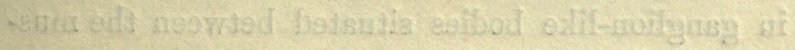

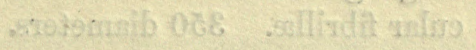




\section{Plate Xli. \\ STRUCTURE OF MUSCLE.}

Fig. 1. A portion of the surface of a striped muscle magnified about 60 diameters, showing the distribution of the blood vessels and fat globules.

2. A fragment of unstriped muscle; the fibres, with their nuclei, in one half of the figure are less distinct than in the other, the filaments in the second half having been submitted to the action of acetic acid. 670 diameters.

3. Muscular fibrillæ of the heart; previous to the action of acetic acid they are observed to be transversely striped; this re-agent however obliterates the stripes and reduces the fibrillæ to the same condition as those of unstriped muscle. 670 diameters.

4. A fragment of a muscle of the frog, showing the distribution of the capillary vessels and nerves; the tubules of these last are observed to terminate in ganglion-like bodies situated between the muscular fibrillæ. 350 diameters. 

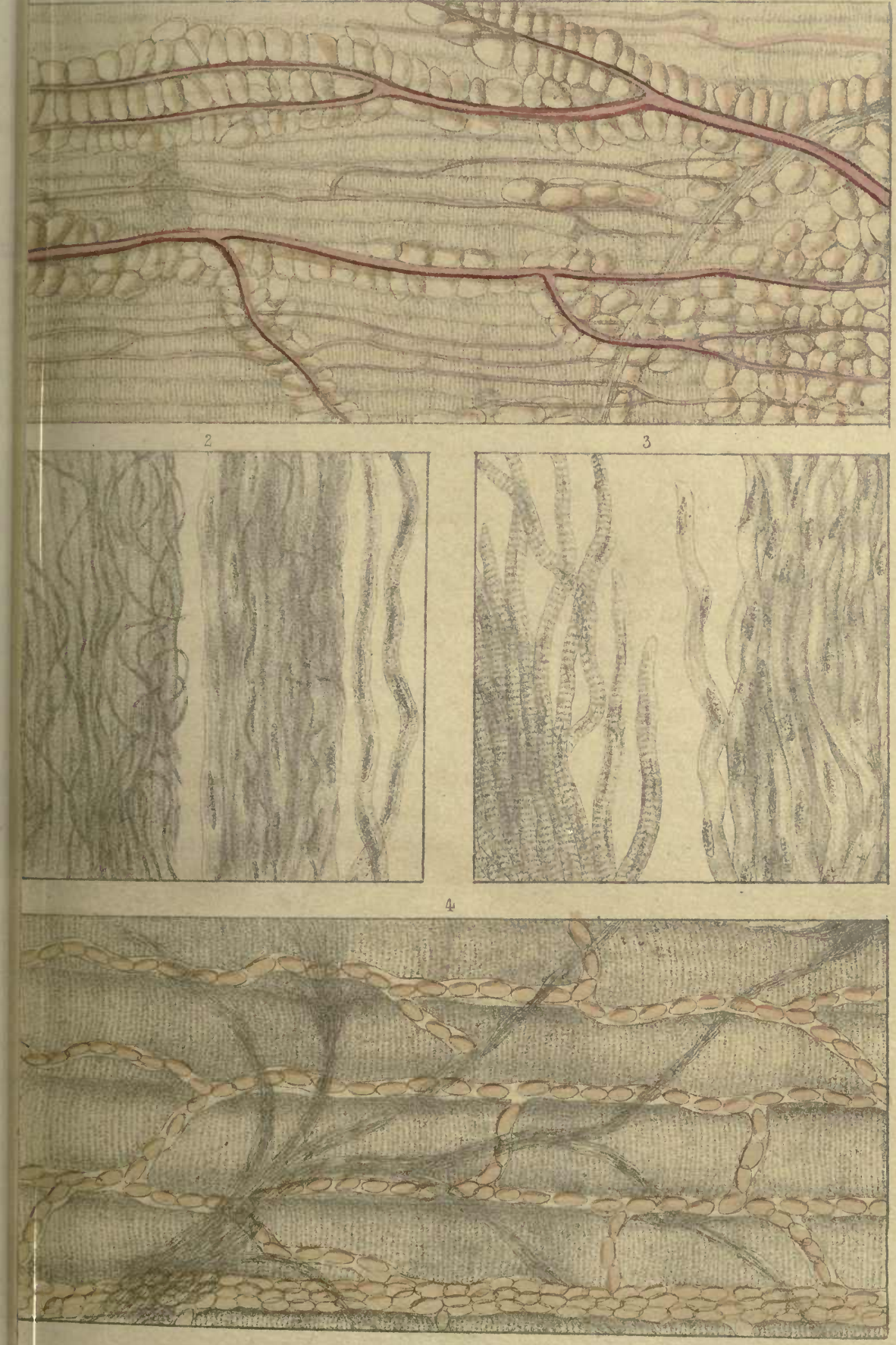



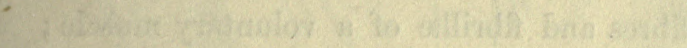

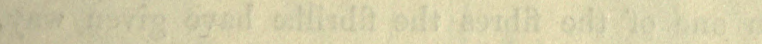

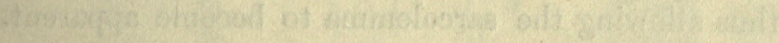

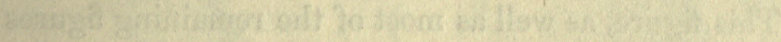

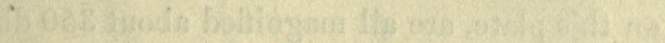

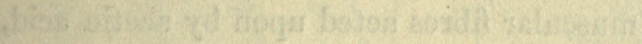

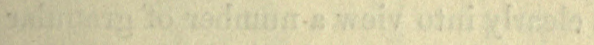

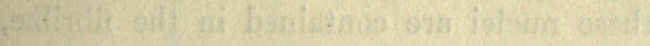

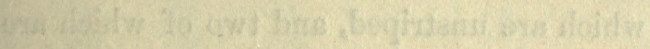

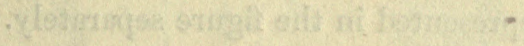

-

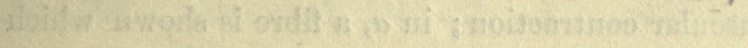

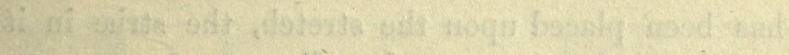

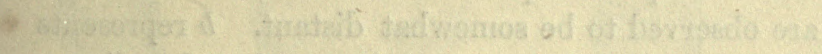

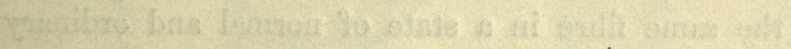

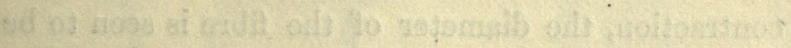

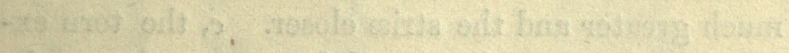

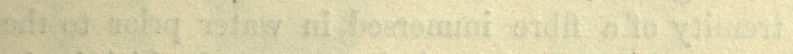

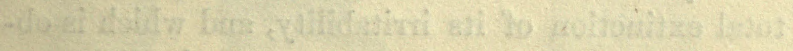

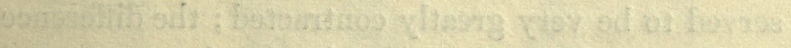
3.

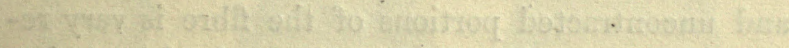

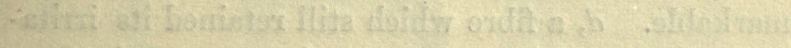

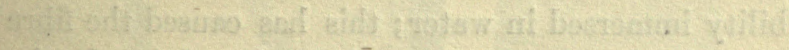

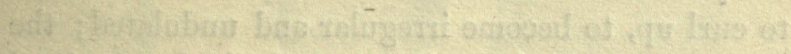

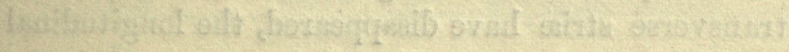
:

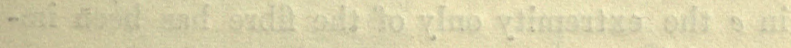

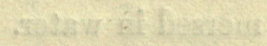

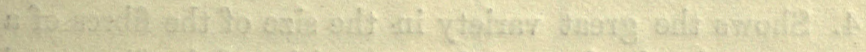

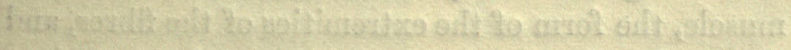

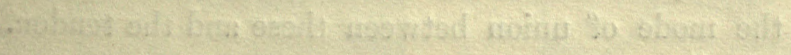

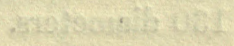

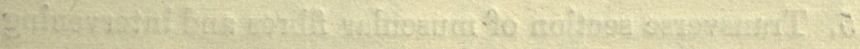

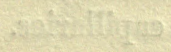




\section{Plate XLII. \\ STRUCTURE OF MUSCLE.}

Fig. 1. Muscular fibres and fibrillæ of a voluntary muscle; in one of the fibres the fibrillæ have given way, thus allowing the sarcolemma to become apparent. This figure, as well as most of the remaining figures on this plate, are all magnified about 350 diameters.

2. Voluntary muscular fibres acted upon by acetic acid, which brings clearly into view a number of granular nuclei; these nuclei are contained in the fibrillæ, many of which are unstriped, and two of which are represented in the figure separately.

3. This figure represents particulars in reference to muscular contraction; in $a$, a fibre is shown which has been placed upon the stretch, the striæ in it are observed to be somewhat distant. $b$ represents the same fibre in a state of normal and ordinary contraction, the diameter of the fibre is seen to be much greater and the striæ closer. $c$, the torn extremity of a fibre immersed in water prior to the total extinction of its irritability, and which is observed to be very greatly contracted; the difference of distance between the strix in the contracted and uncontracted portions of the fibre is very remarkable. $d$, a fibre which still retained its irritability immersed in water; this has caused the fibre to curl up, to become irregular and undulated; the transverse striæ -have disappeared, the longitudinal markings at the same time being more apparent; in $e$ the extremity only of the fibre has been immersed in water.

4. Shows the great variety in the size of the fibres of a muscle, the form of the extremities of the fibres, and the mode of union between these and the tendon. 130 diameters.

5. Transverse section of muscular fibres and intervening capillaries. 

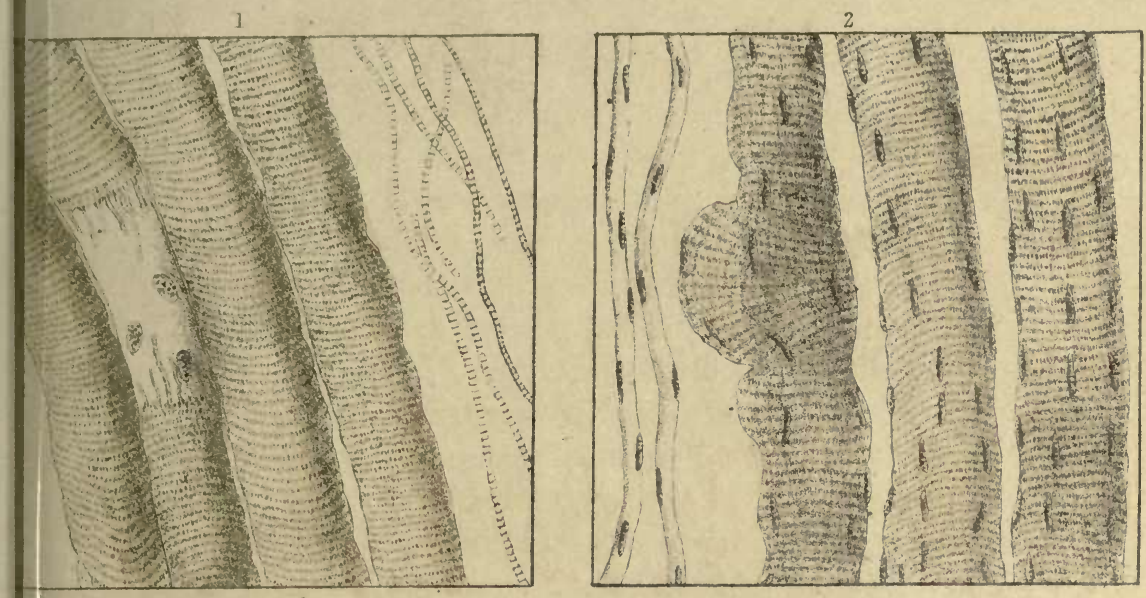

3
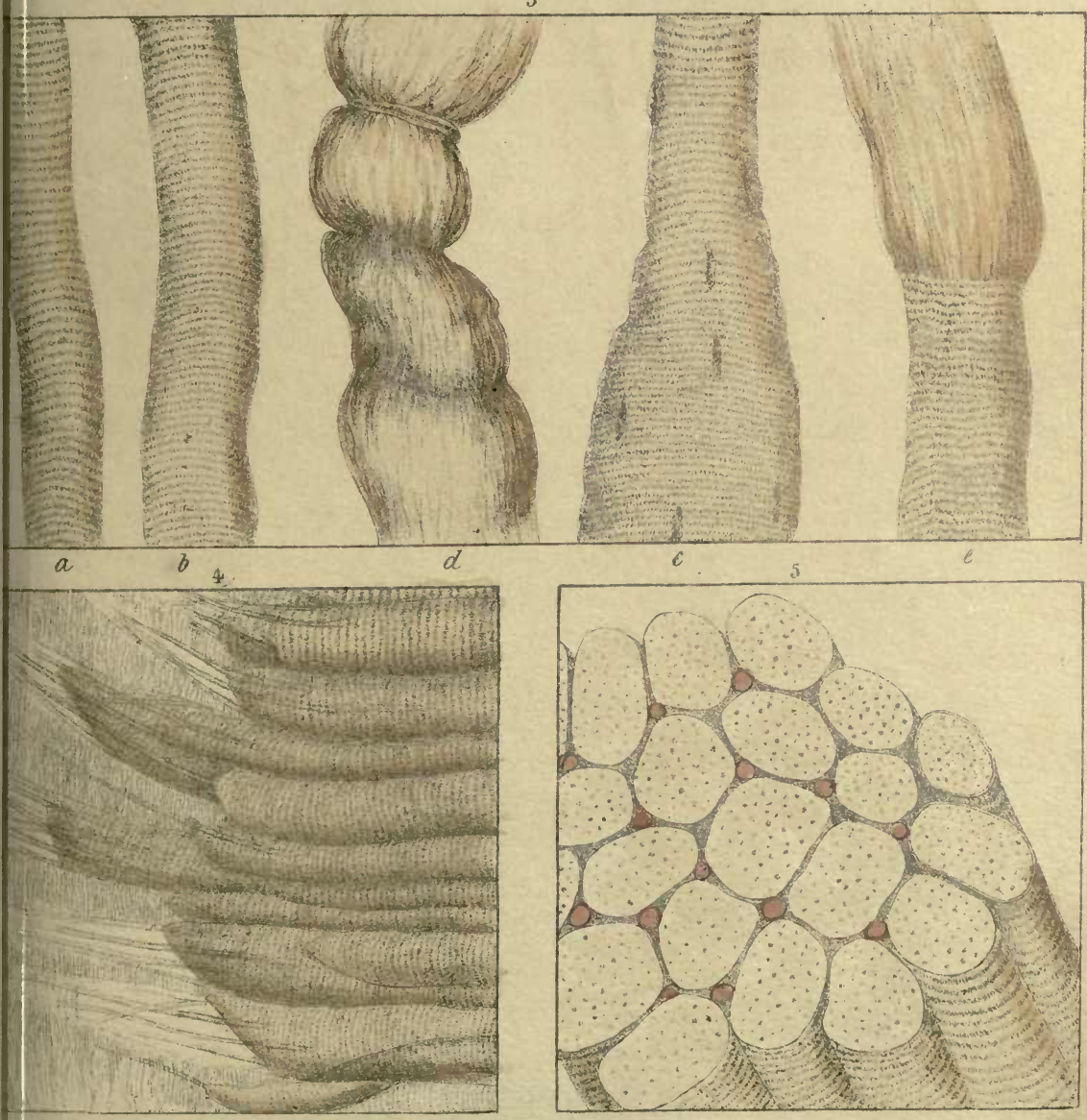
Ary

(8)

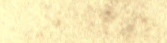

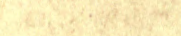

$x^{4}+x^{x}=5$

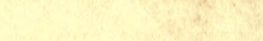




\section{Plate XLIII.}

Fig. 1. A portion of a voluntary muscle of a foetus about three months old, magnified 670 diameters, presenting numerous nuclei, some of which are embedded in the fibres, and others lie between them. At this early period the fibres are formed of but few fibrillæ. The small size of these fibres in comparison with those of the adult, and which are represented in fig. 6., is worthy of note. 670 diameters.

2. Illustrates the development of the inelastic form of fibrous tissue from nucleated and granular cells. This figure was also taken from a foetus at about the third inonth.

3. A portion of dartos magnified 350 diameters, showing the different structures which enter into its composition, viz., the blood vessels, the bands of elastic fibrous tissue, and lastly, the bundles of inelastic fibrous tissue.

4. A transverse section of a portion of one of the corpora cavernosa penis, showing the apertures of the vessels or cells of which they are principally composed, as well as the walls of those cells which are formed, not of nucleated elastic tissue, but of branched and reticular elastic filaments. This figure is magnified only a few diameters.

5. Muscular fibres of voluntary muscle, disposed in a zigzag manner; this disposition was formerly considered to be normal, and to be that assumed by the fibres of every muscle in a state of contraction, a view which is certainly erroneous; it is encountered in a greater or less degree in all fried and roasted meats.

6. Striped muscular fibres, magnified 670 diameters. It will be seen from the figure, that the surface of each fibre is raised into ridges with a narrow space intervening between each ridge, and further, that 
the ridges are marked out into quadrangular spaces, each of which corresponds with a division of the fibrillæ themselves. Now this form of the surface of a striped fibre is especially interesting from the fact of its enabling us to afford a satisfactory explanation of the nature of the strix themselves. The most recent explanation given of the formation of the strix of the voluntary muscular fibre, and which has been generally adopted, is, that it depends upon the circumstance that the lines on the fibrilla are placed so as exactly to correspond with each other, and that thus a number of smaller lines concur to form a larger one, the stria of the entire fibre. Such an exact arrangement of the lines on the fibrillæ there is little doubt does really exist, but it is yet insufficient to explain all the characters presented by the muscular striæ. Thus, although the striæ are usually strongly marked and broad, yet they have no certain characteristics, either as to position or appearance. In what way then is the muscular stria produced? A careful examination of a recent muscular fibre with an object glass of the one-eighth of an inch focus will satisfy the observer, that the muscular stria is not a thing of shape and substance itself, but a mere shadow, caused by the ridges into which the surface of the fibre is raised, and which sometimes falls on one side the ridge, sometimes on the other, and frequently in the groove which runs between the ridges, according to the direction of the light, and the focus in which the object is viewed. Of the correctness of this explanation it does not appear to me that there can be a shadow of doubt. 

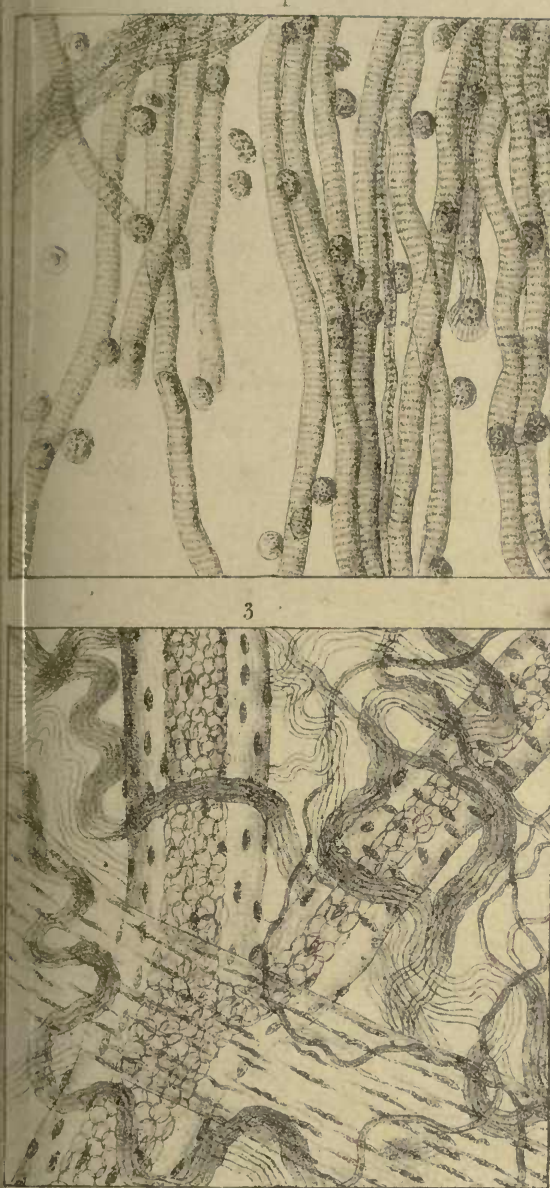

6

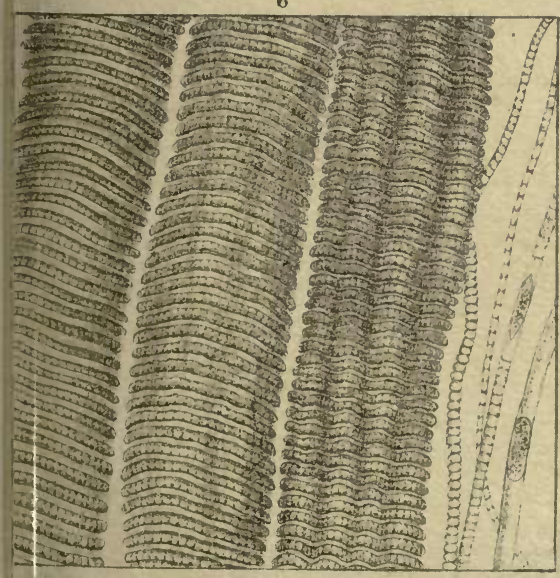

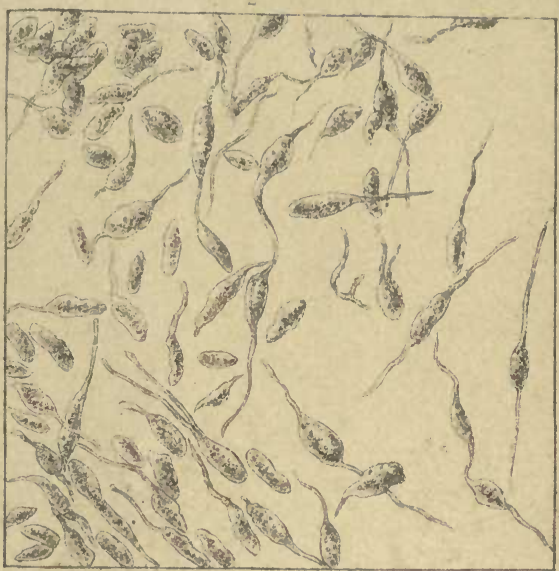
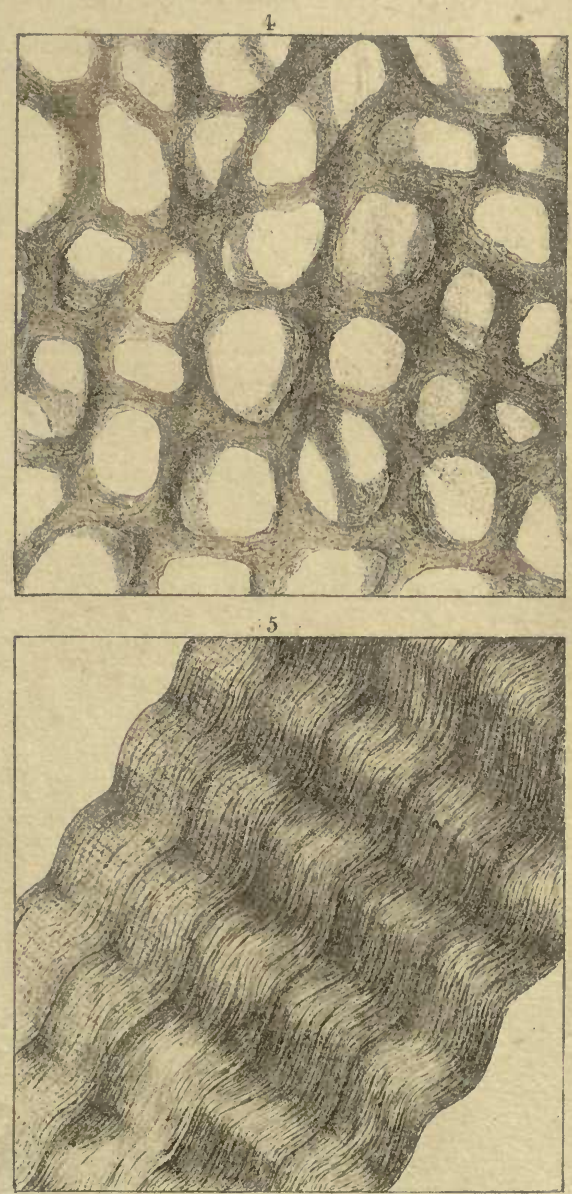


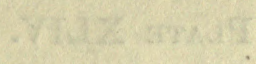

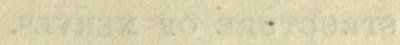

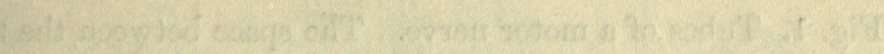

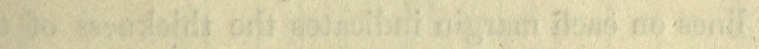

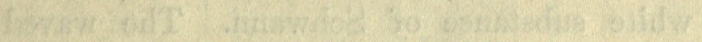

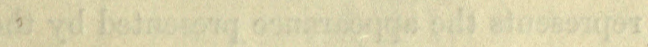

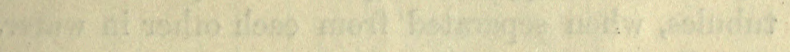

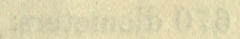

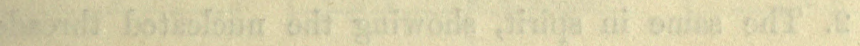
ace gis.

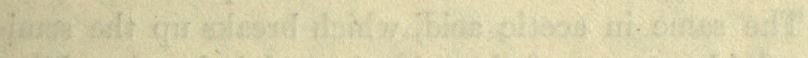

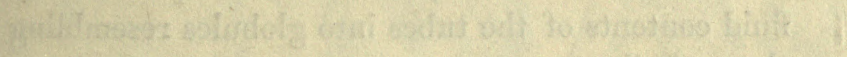

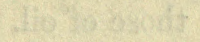

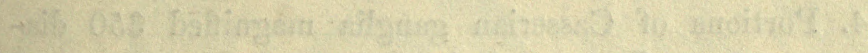

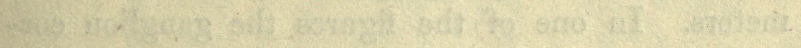

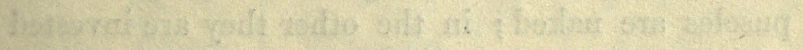

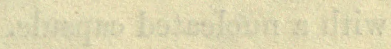

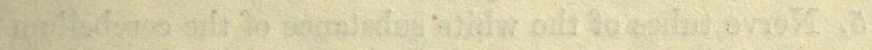

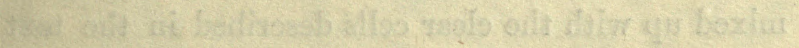

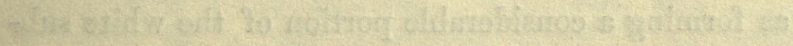

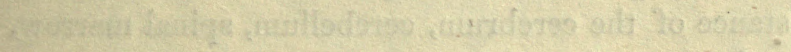

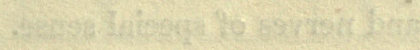

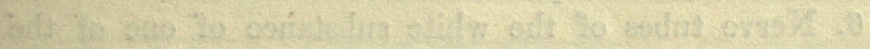

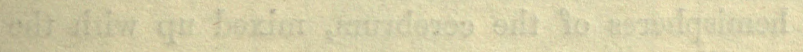

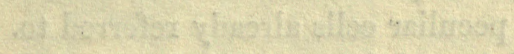

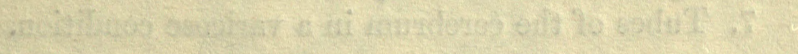




\section{Plate XLIV. \\ STRUCTURE OF NERVES.}

Fig. 1. Tubes of a motor nerve. The space between the two lines on each margin indicates the thickness of the white substance of Schwann. The waved tube represents the appearance presented by the nervous tubules, when separated from each other in water. 670 diameters.

2. The same in spirit, showing the nucleated threads of which the neurolemma is made up.

3. The same in acetic acid, which breaks up the semifluid contents of the tubes into globules resembling those of oil.

4. Portions of Casserian ganglia magnified 350 diameters. In one of the figures the ganglion corpuscles are naked; in the other they are invested with a nucleated capsule.

5. Nerve tubes of the white substance of the cerebellum mixed up with the clear cells described in the text as forming a considerable portion of the white substance of the cerebrum, cerebellum, spinal marrow, and nerves of special sense.

6. Nerve tubes of the white substance of one of the hemispheres of the cerebrum, mixed up with the peculiar cells already referred to.

7. Tubes of the cerebrum in a varicose condition. 

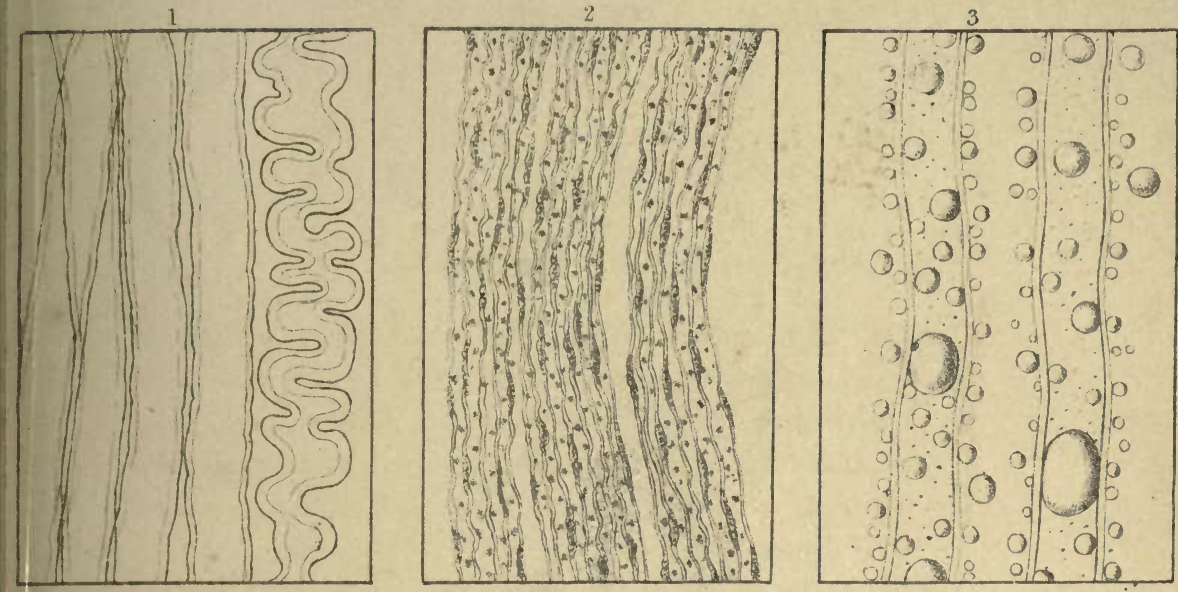

4
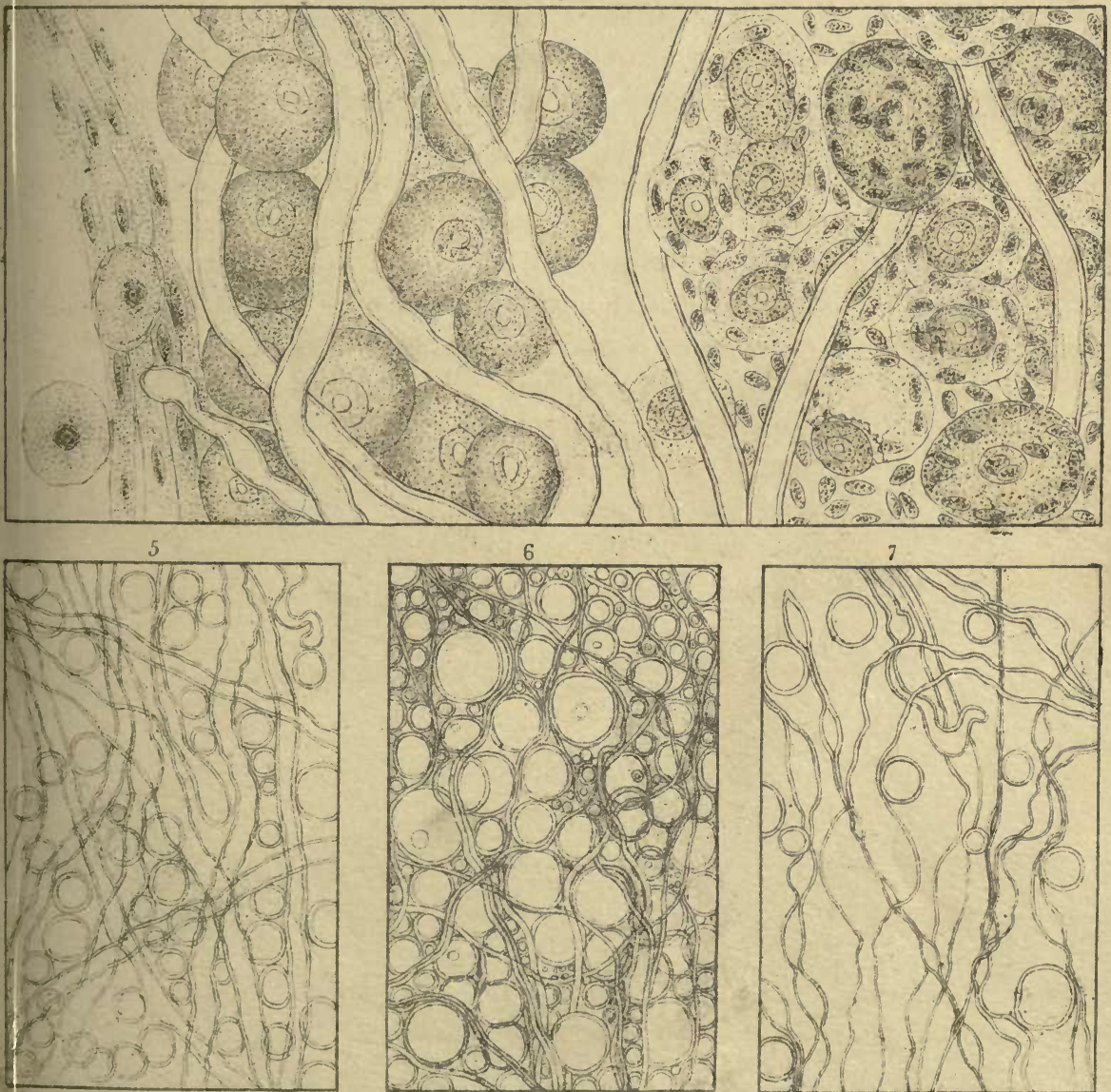

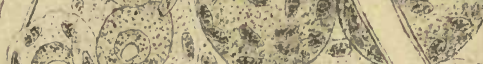

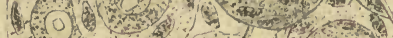
$\left(\begin{array}{cc}3 \\ 0\end{array}\right.$

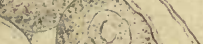
f 1 (1)

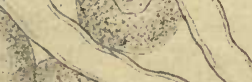

(1) $(10)$

(1)
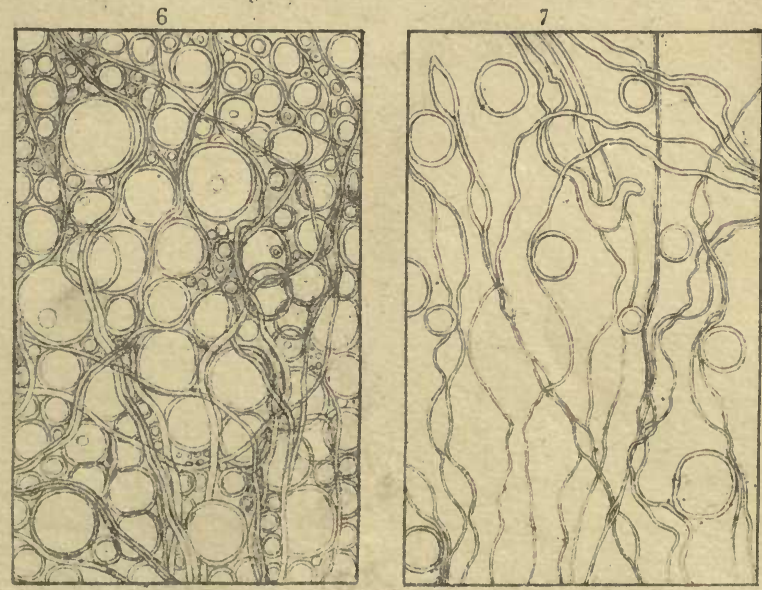


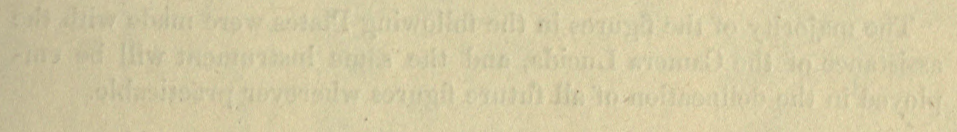

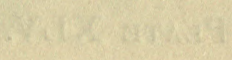

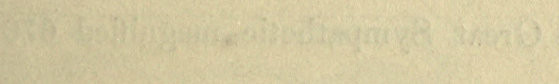

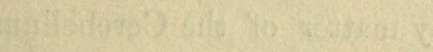

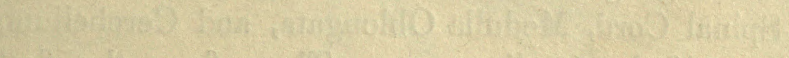

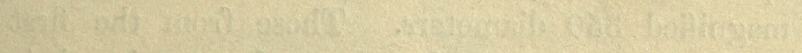

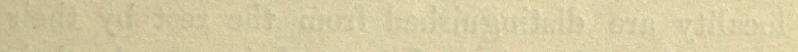

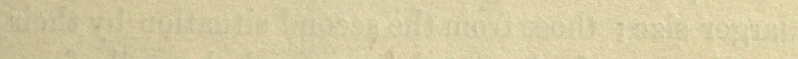

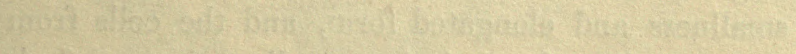

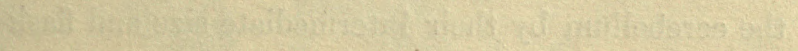

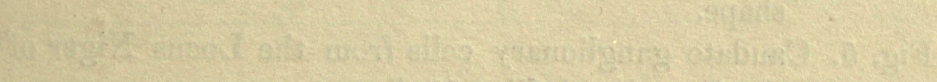

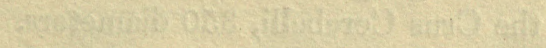

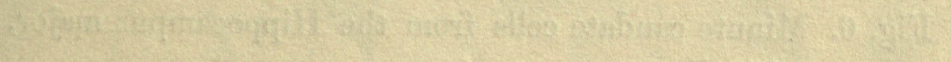

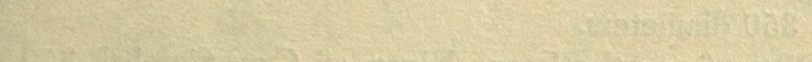

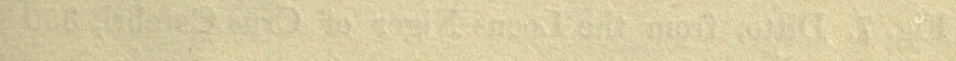




\section{EXPLANATION OF THE PLATES.}

The majority of the figures in the following Plates were made with the assistance of the Camera Lucida, and the same instrument will be employed in the delineation of all future figures wherever practicable.

\section{Plate XLV.}

Fig. 1. Filaments of the Great Sympathetic magnified 670 diameters.

Fig. 2. Cells of the grey matter of the Cerebellum, outer stratum.

Fig. 3. Ditto, inner stratum.

Fig. 4. Caudate ganglionary cells from the grey matter of the Spinal Cord, Medulla Oblongata, and Cerebellum, magnified 350 diameters. Those from the first locality are distinguished from the rest by their larger size; those from the second situation by their smallness and elongated form, and the cells from the cerebellum by their intermediate size and flask shape.

Fig. 5. Caudate ganglionary cells from the Locus Niger of the Crus Cerebelli, 350 diameters.

Fig. 6. Minute caudate cells from the Hippocampus major, 350 diameters.

Fig. 7. Ditto, from the Locus Niger of Crus Cerebri, 350 diameters. 

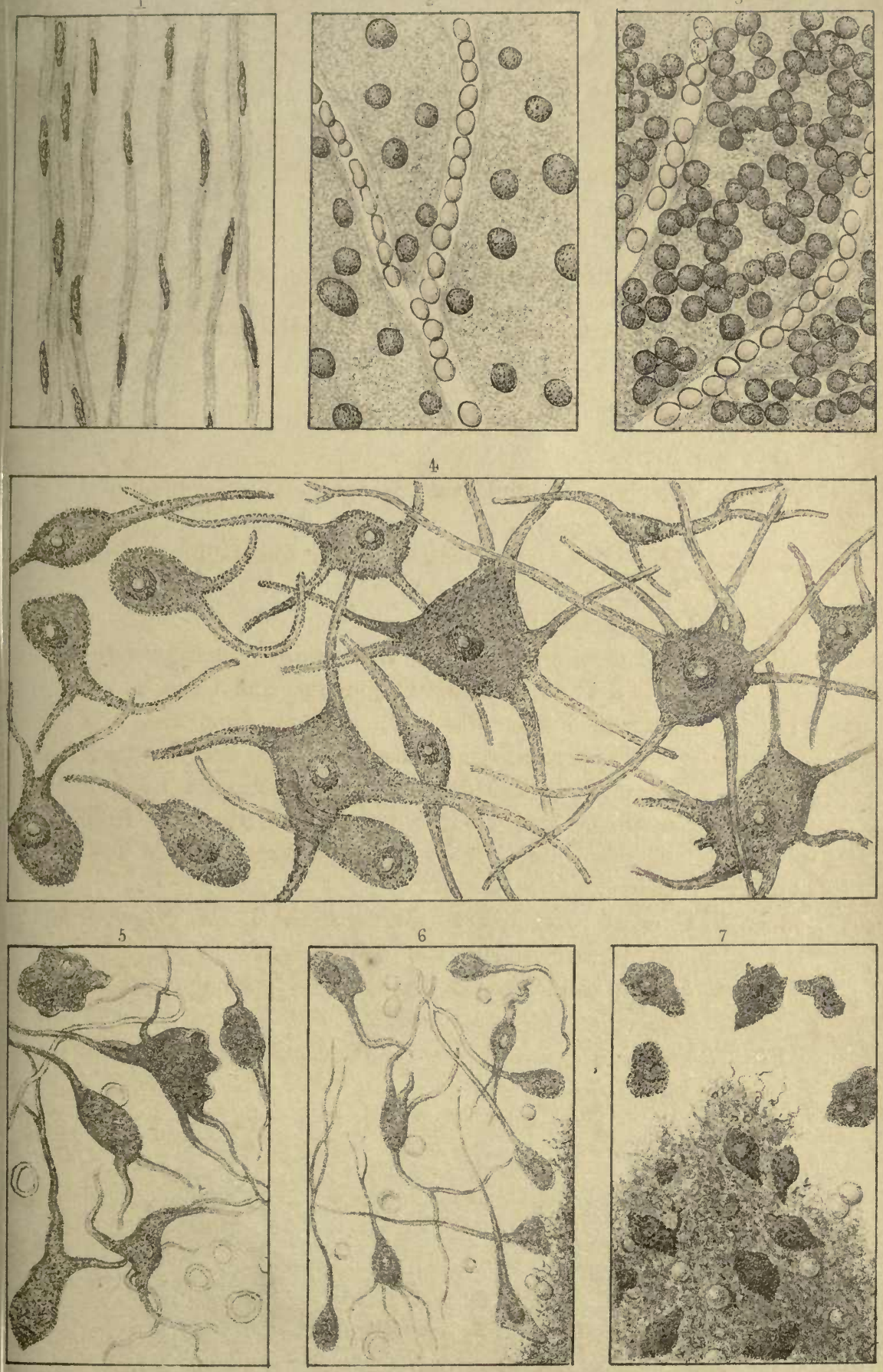


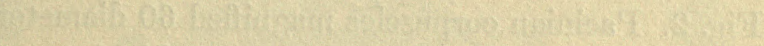

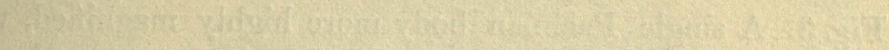

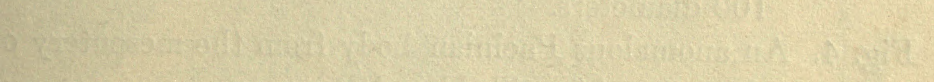

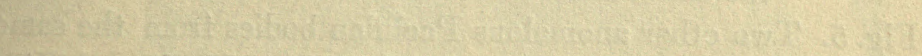

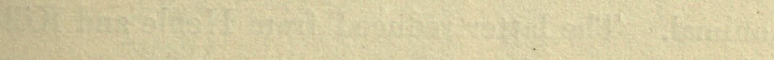

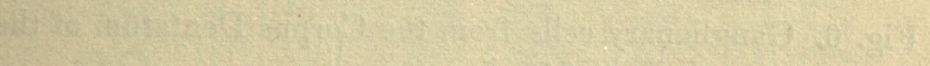




\section{Plate XLVI.}

Fig. 1. Pacinian corpuscles attached to the cutaneous nerves of the palm of the hand. Natural size. After Todd and Bowman.

Fig. 2. Pacinian corpuscles magnified 60 diameters.

Fig. 3. A single Pacinian body more highly magnified, viz. 100 diameters.

Fig. 4. An anomalous Pacinian body from the mesentery of the cat. After Todd and Bowman.

Fig. 5. Two other anomalous Pacinian bodies from the same animal. The latter reduced from Henle and Kölliker.

Fig. 6. Ganglionary cells from the Corpus Dentatum of the Cerebellum, 350 diameters. 


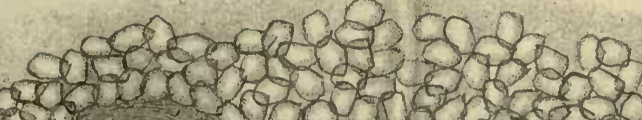

os

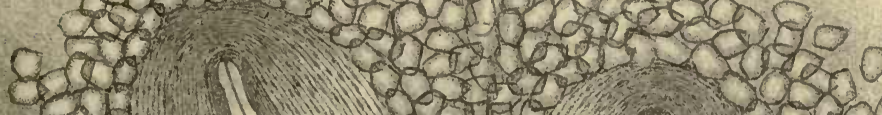

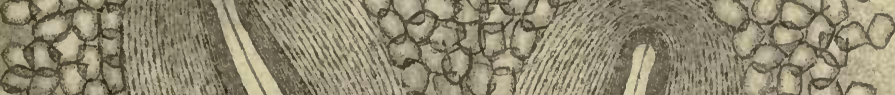

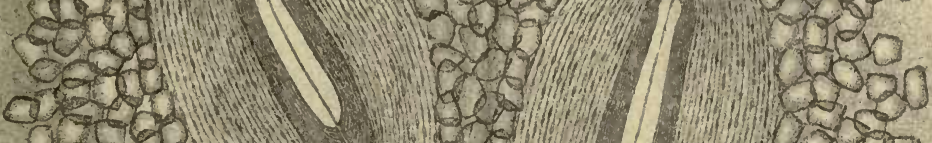

0652 - D. 07

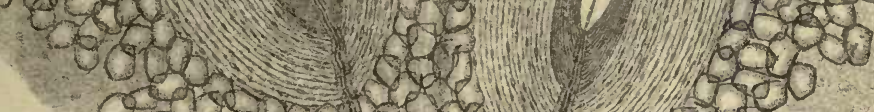

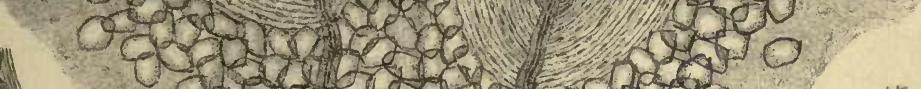

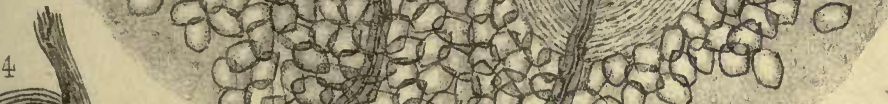

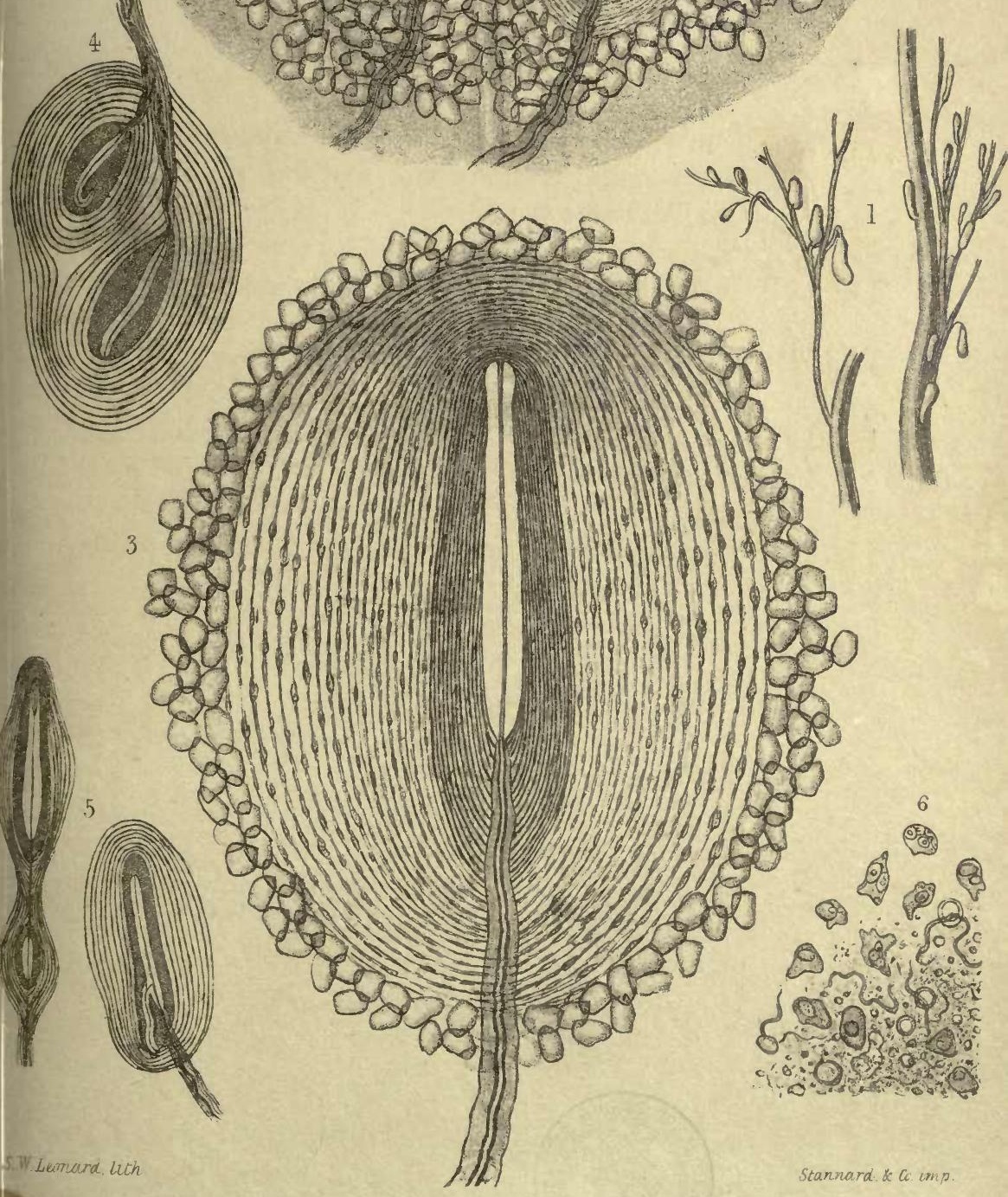




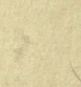


i.

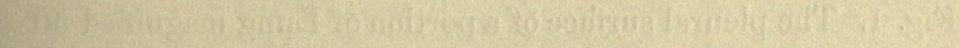

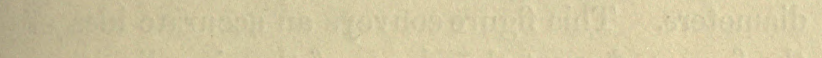

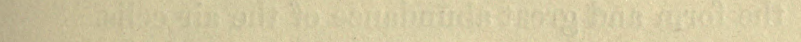

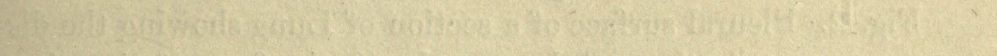

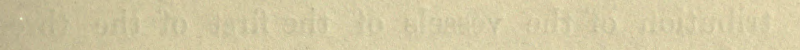

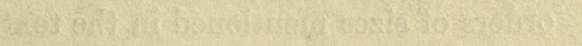




\section{Plate XLVII.}

Fig. 1. The pleural surface of a portion of Lung magnified 30 diameters. This figure conveys an accurate idea of the form and great abundance of the air cells.

Fig. 2. Pleural surface of a section of Lung showing the distribution of the vessels of the first of the three orders of sizes mentioned in the text.

Fig. 3. Ditto of Lung magnified 100 diameters. The vessels in this are not injected, but are represented as they appeared in a section which had become slightly dried. 


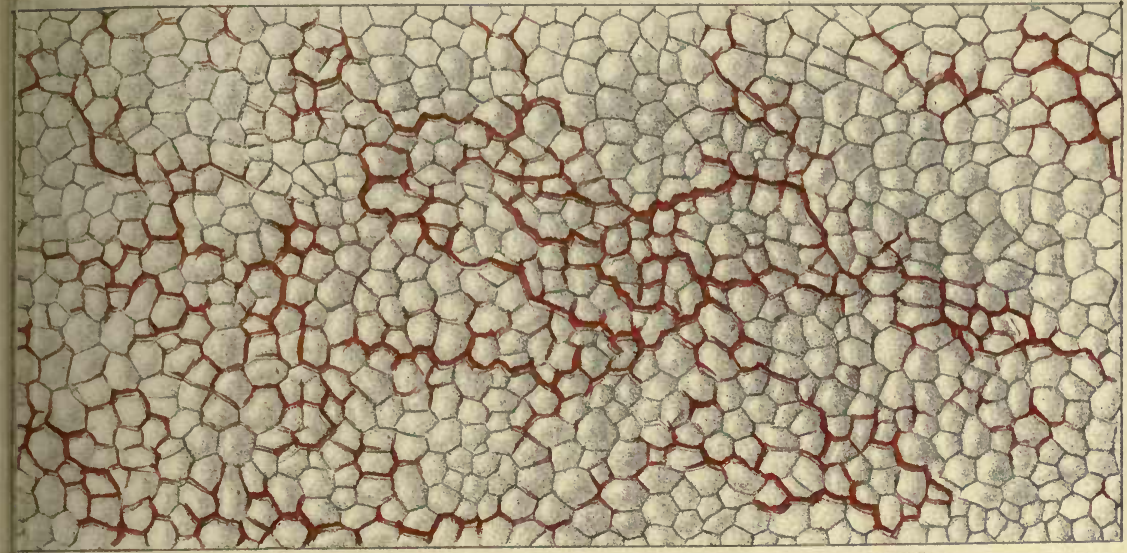

सैस प्रु

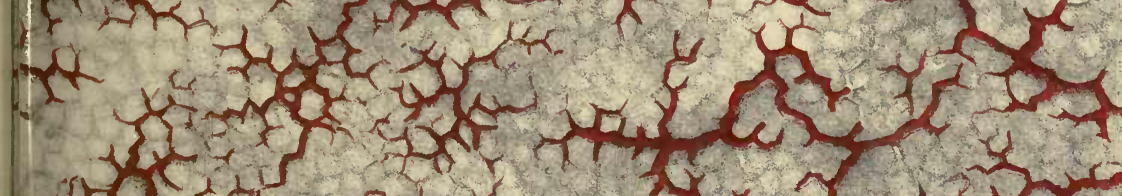

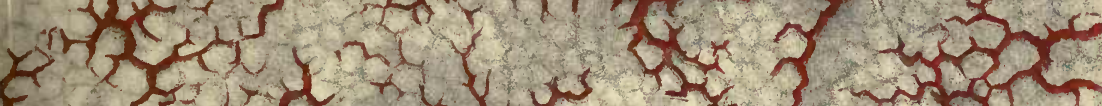
E 7 k o

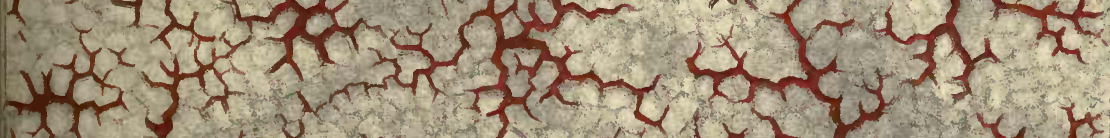

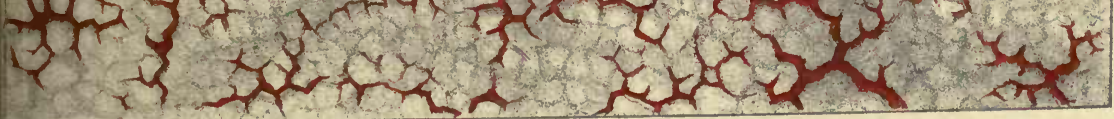

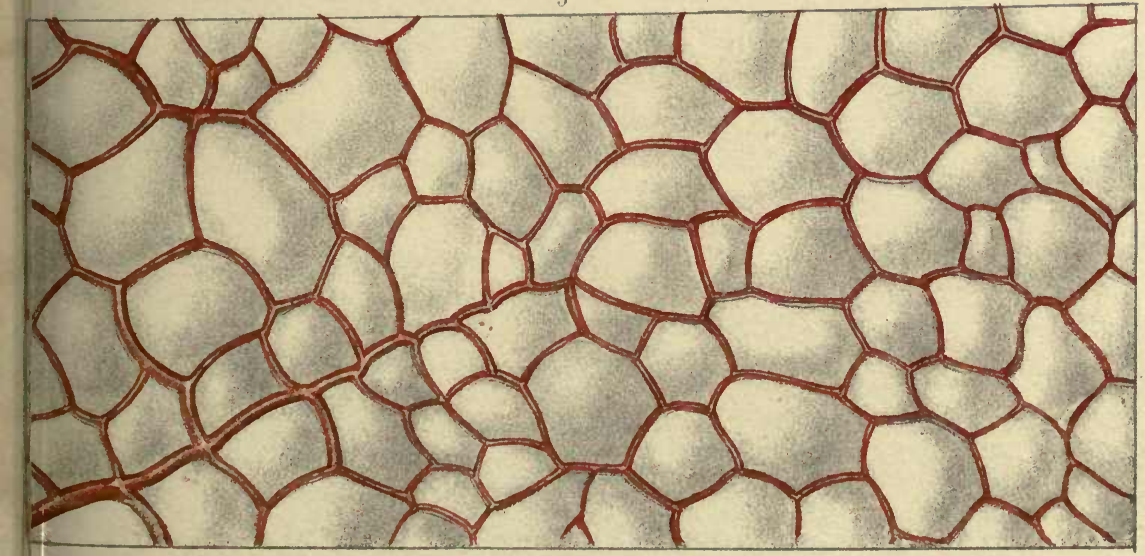




\section{PLATE XLVIII.}

Fig. 1. A section of Lung from beneath the pleural surface magnified 100 diameters, injected with tallow

Fig. 2. Casts or models of the Air Cells magnified 350 diameters, representing the variety in size and form of these cells as well as the shape and number of the openings of communication.

Fig. 3. Deep section of Lung injected with size: the majority of the cells are observed to be filled with the casts tipped with colouring matter: other cells may also be seen without casts : these have evidently been cut across, exposing to view the ciliated epithelium which lines them. 


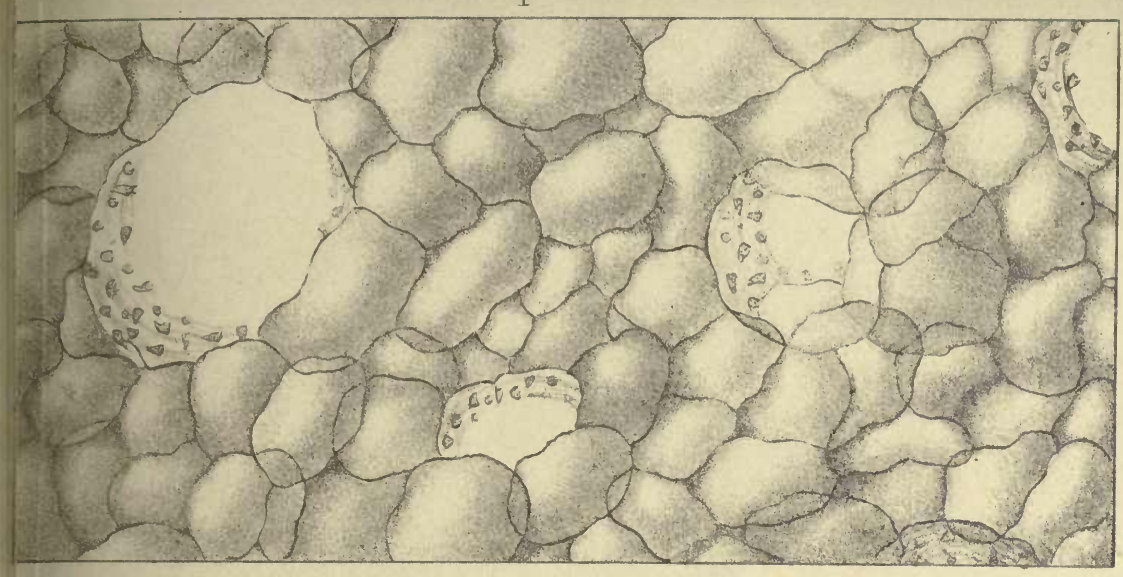

2

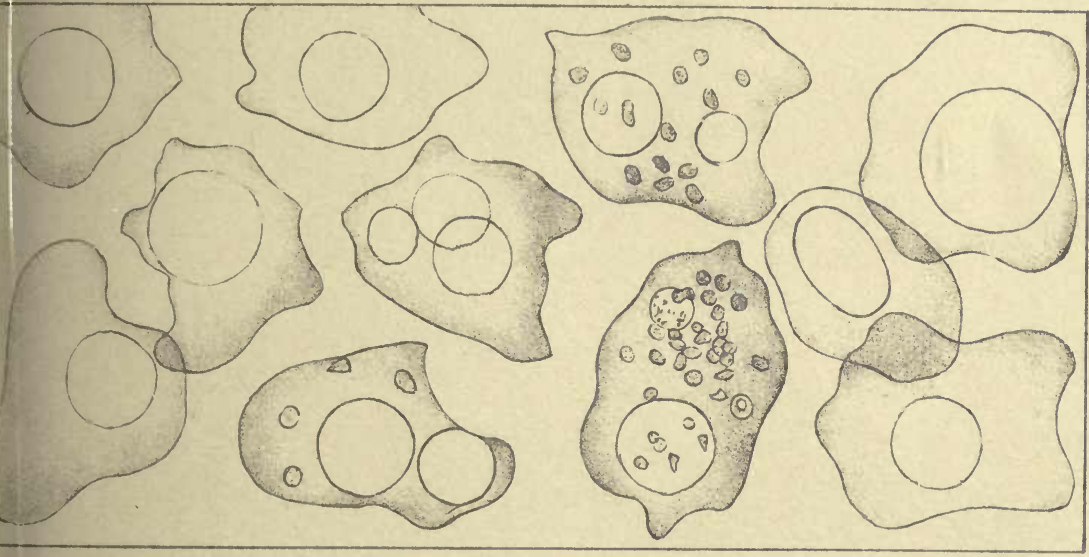

\section{3}

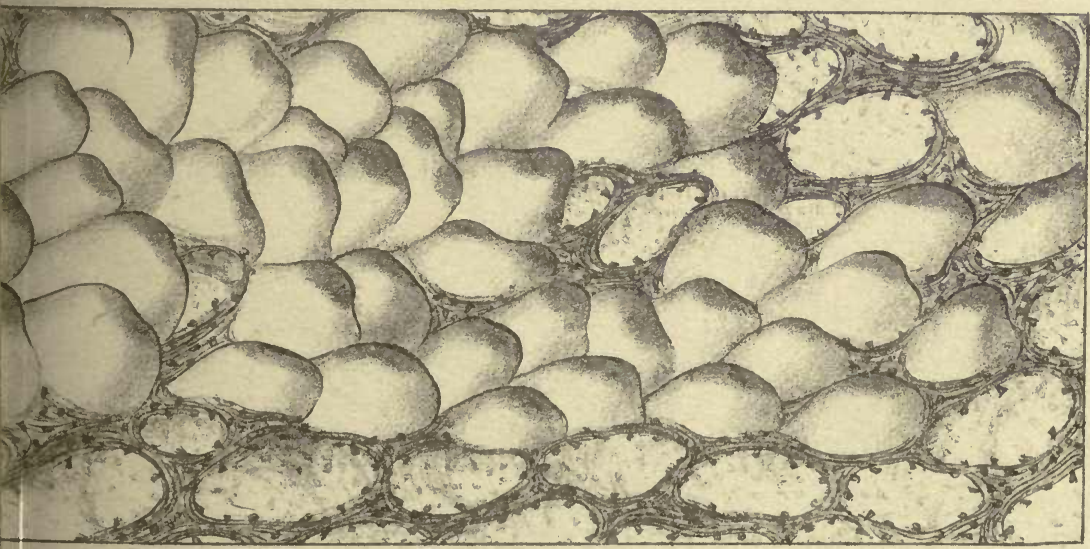




\section{EXPLANATION OF THE PLATES.}

\section{Plate XLIX.}

Fig. 1. A portion of the pleural surface of the human lung, with the vessels of the second order injected. Magnified 100 diameters.

Fig. 2. A section of the human lung, showing the natural appearance and form of the air cells as seen without injection, also exhibiting numerous particles of the conoidal ciliated epithelium which lines them.

Fig. 3. Capillaries of the human lung. Magnified 100 diameters. The drawing was made from a very beautiful preparation injected by Mr. Quekett. 


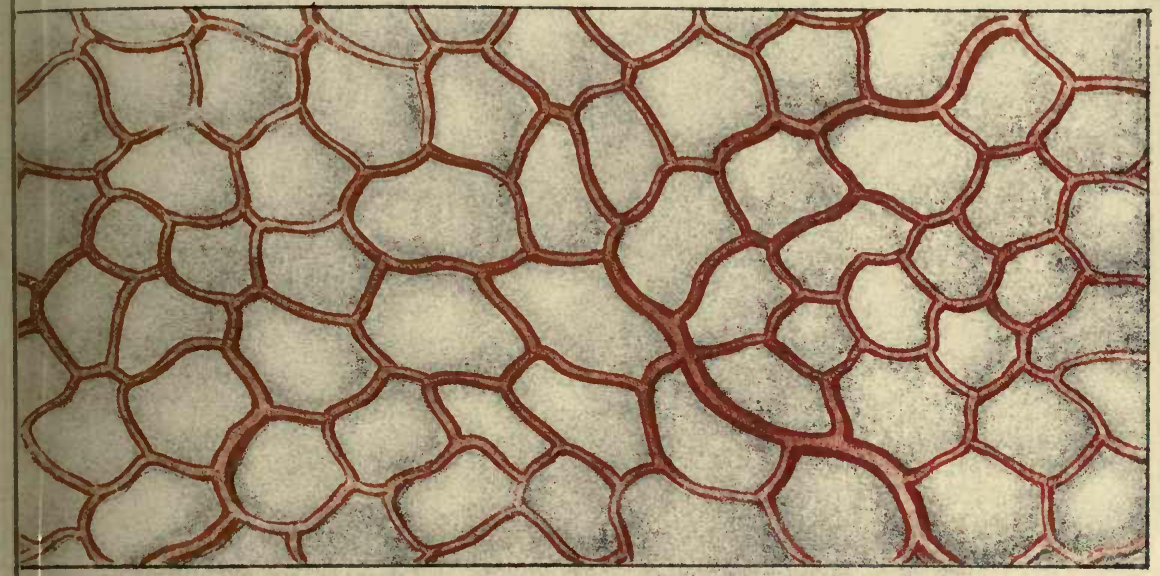

2

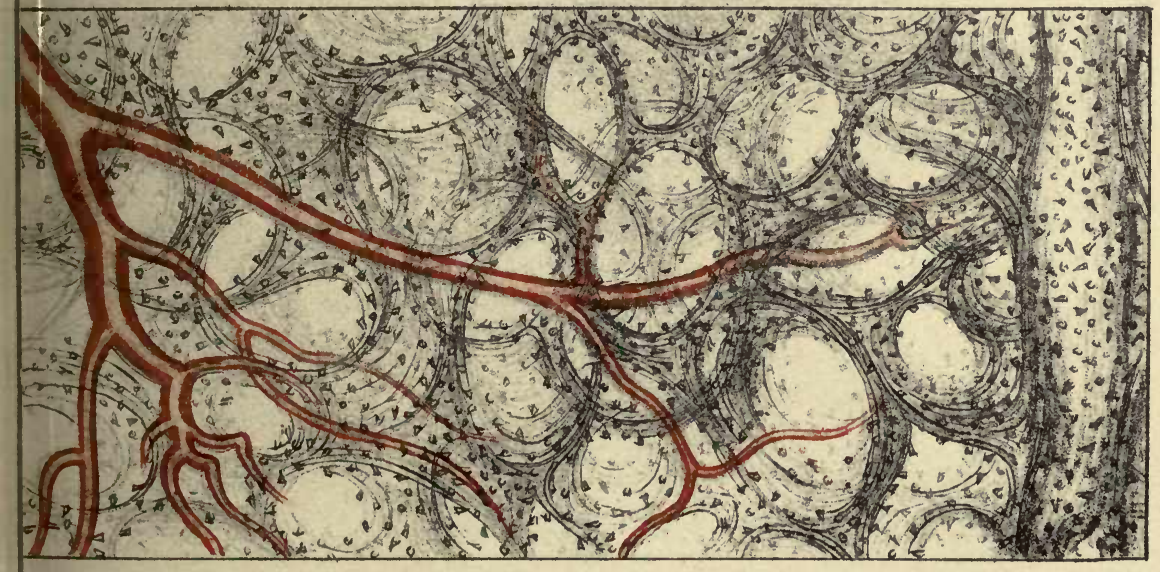

3

Wम

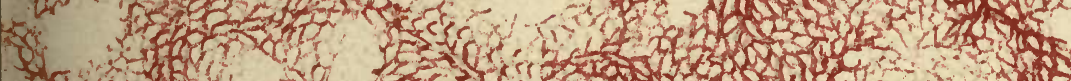

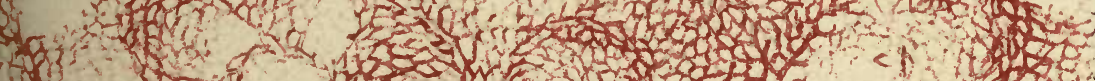
(1) 1 (1)

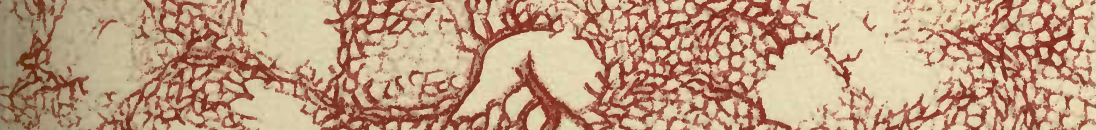

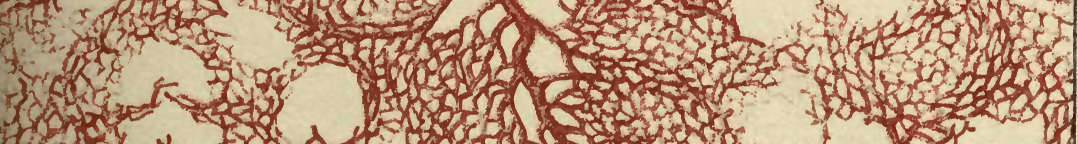
(1)

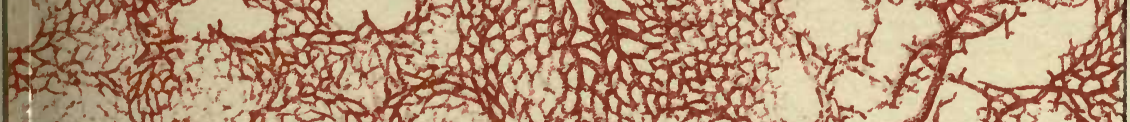

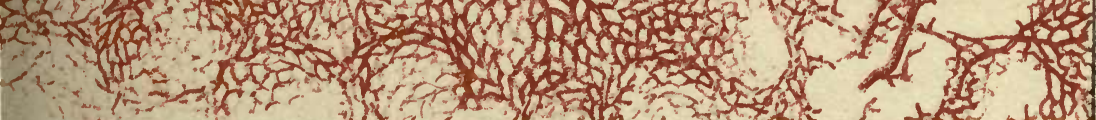

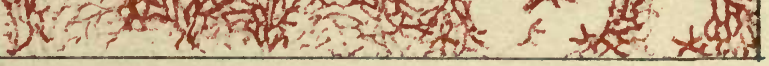




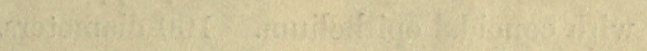

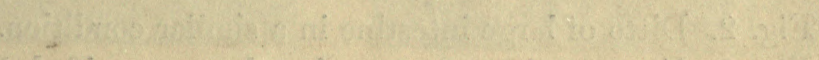

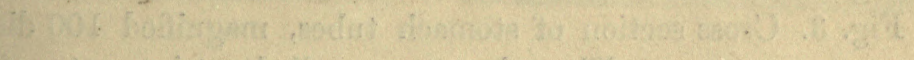

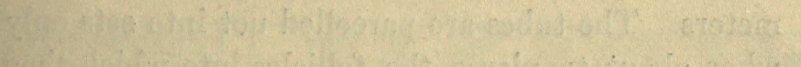

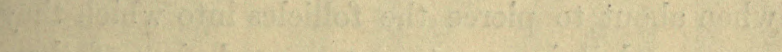

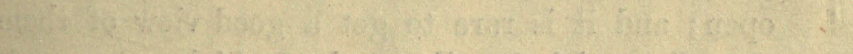

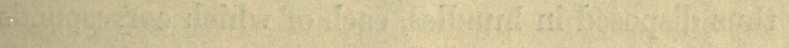

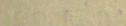

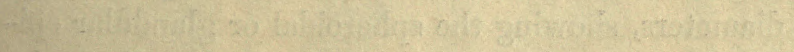

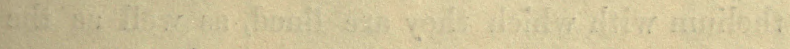

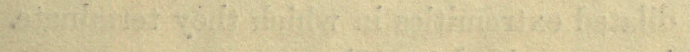

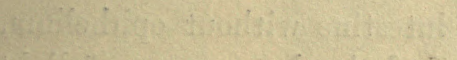

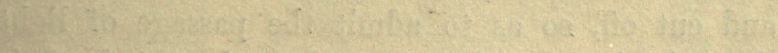

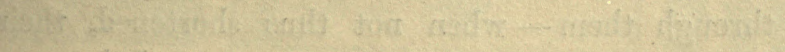

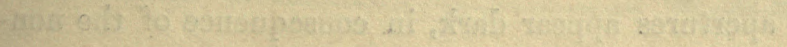

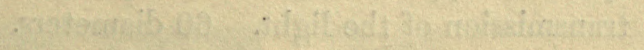

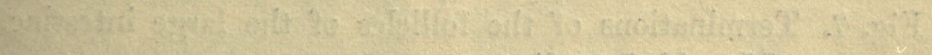

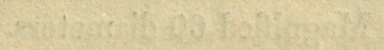




\section{Plate L.}

Fig. 1. Follicles of the stomach as they appear when lined with conoidal epithelium. 100 diameters.

Fig. 2. Ditto of large intestine in a similar condition.

Fig. 3. Cross section of stomach tubes, magnified 100 diameters. The tubes are parcelled uot into sets only when about to pierce the follicles into which they open; and it is rare to get a good view of them thus disposed in bundles, each of which corresponds to the base of a follicle.

Fig. 4. Longitudinal view of stomach tubes, magnified 220 diameters, showing the spheroidal or glandular epithelium with which they are lined, as well as the dilated extremities in which they' terminate.

Fig. 5. Ditto, magnified 100 diameters.

Fig. 6. Follicles of the large intestine without epithelium, and cut off, so as to admit the passage of light through them - when not thus shortened, their apertures appear dark, in consequence of the nontransmission of the light. 60 diameters.

Fig. 7. Terminations of the follicles of the large intestine. Magnified 60 diameters. 


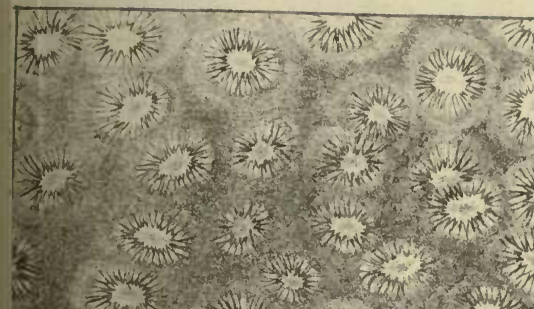

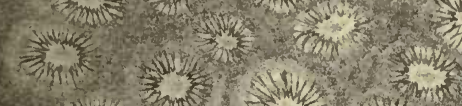
wherten 35 sin

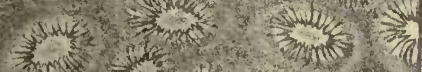

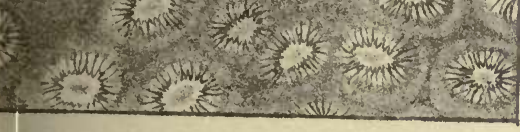

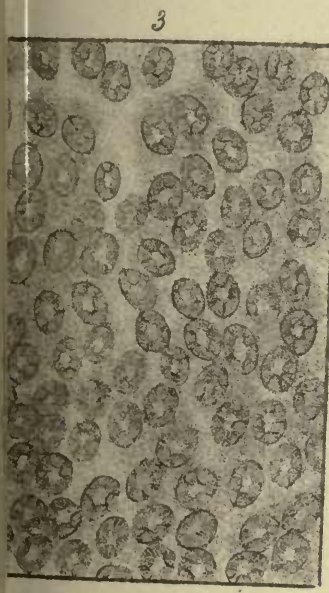

6

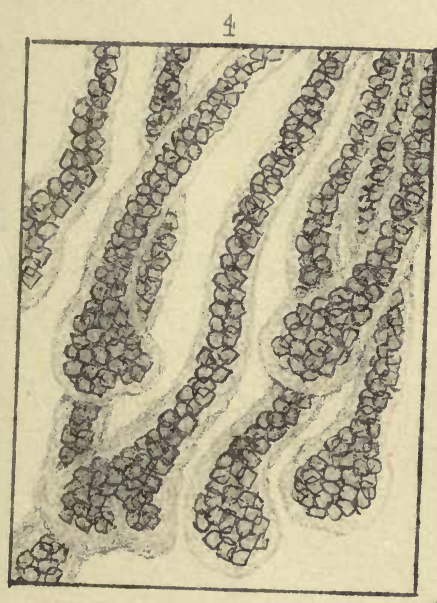

2
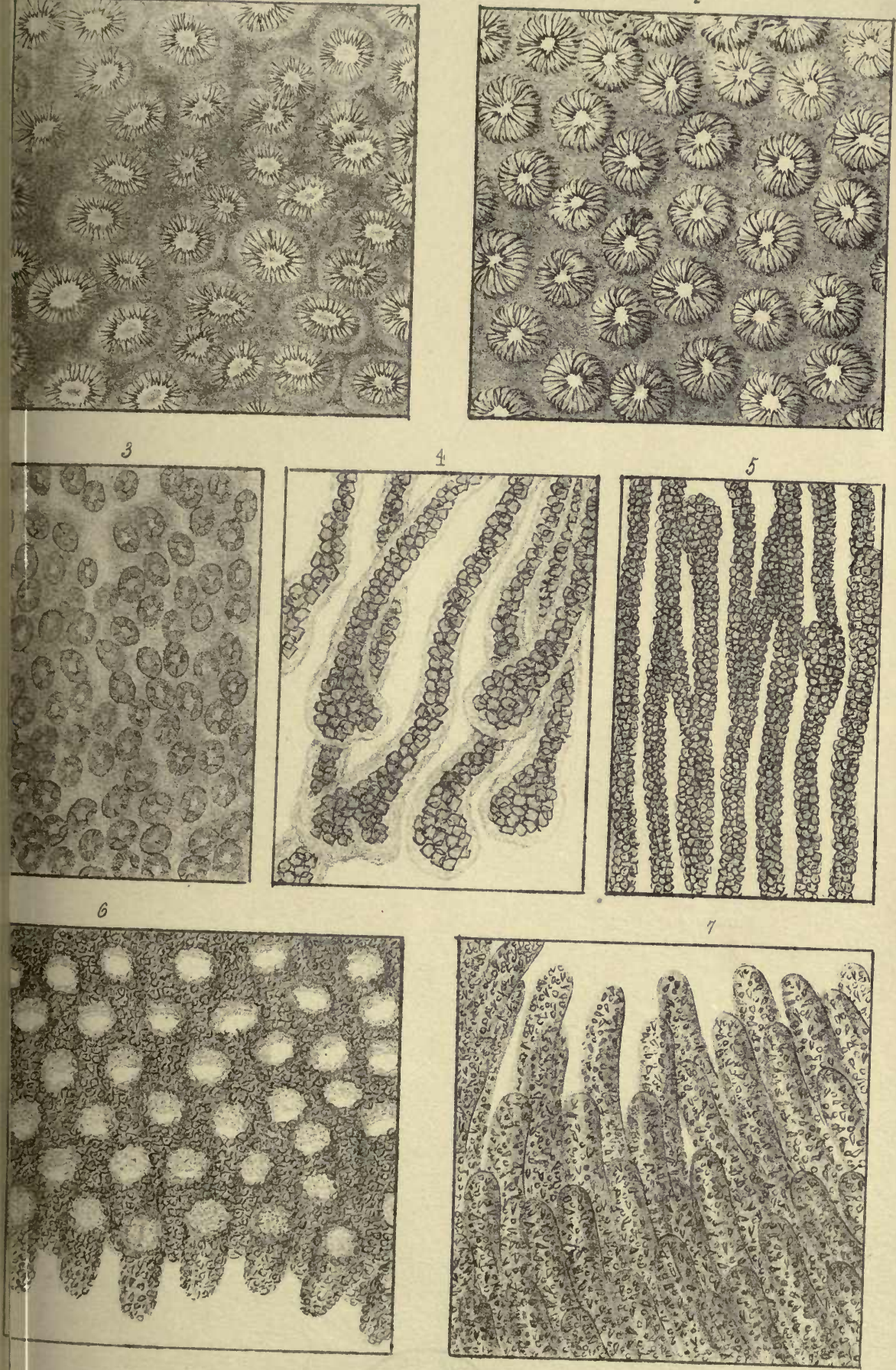


\section{Plate LI.}

Fig. 1. Blood vessels of the follicles of the appendix vermiformis injected. Magnified 100 diameters.

Fig. 2. Blood vessels of the follicles of the stomach of a cat beautifully injected. The drawing was made from a preparation of Dr. Hanfield Jones. 100 diameters.

Fig. 3. Villi of the upper part of the small intestine, magnified 60 diameters. Drawing made from a preparation of Dr. Jones.

Fig. 4. Ditto, from the lower portion of the same.

Fig. 5. Ditto of the foal, injected white and red, the arteries being red and the veins white. Magnified 60 diameters. Drawing made from a preparation pre. sented by Professor Hyrtle of Prague to the London Microscopical Society.

Fig. 6. Solitary glands of the large intestine in a case of cholera in a child. Magnified with a lens only. 


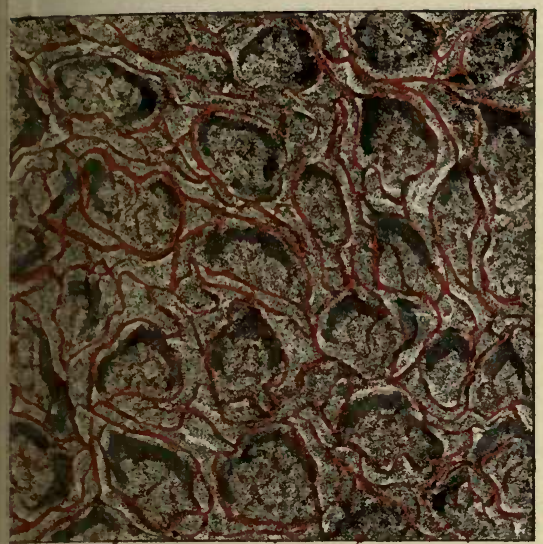

3

15014025502500

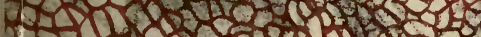

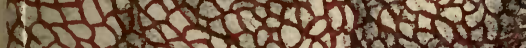
If DIf

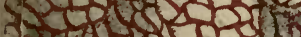

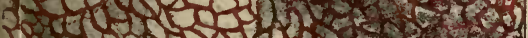

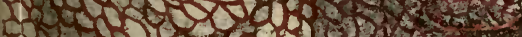

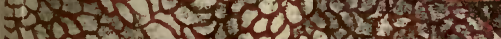

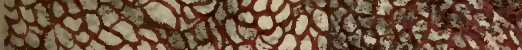

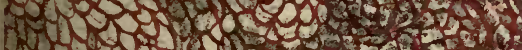

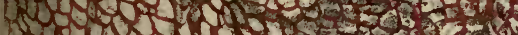

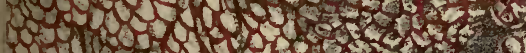

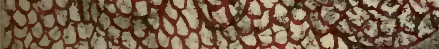

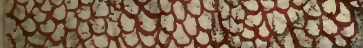

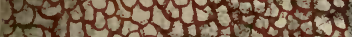

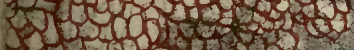
2013.

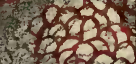

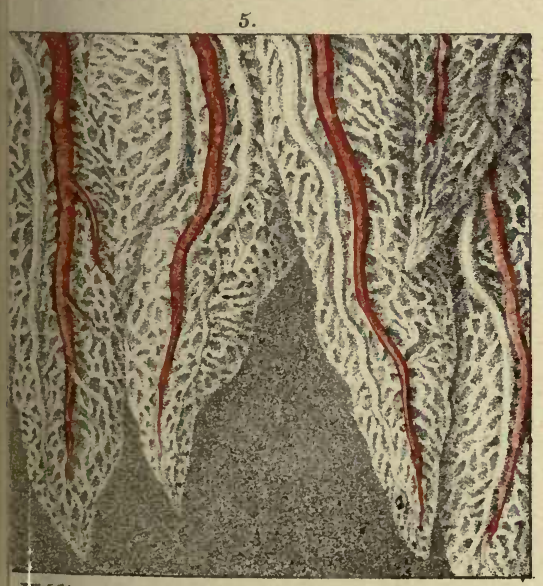

BWIller del ct heth.
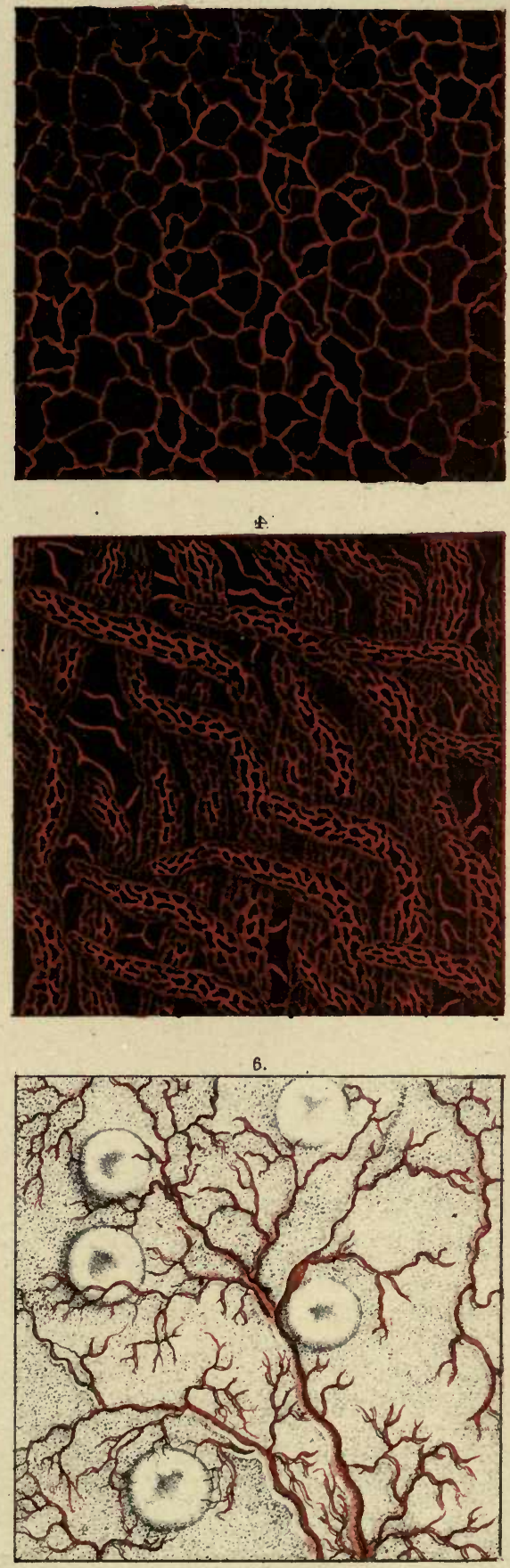


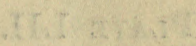

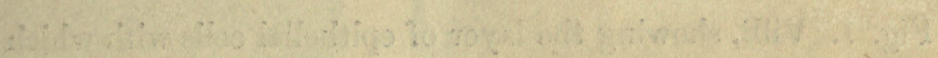

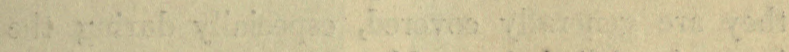

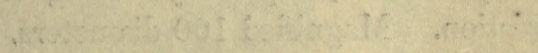

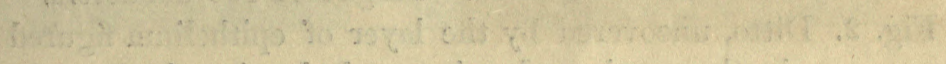

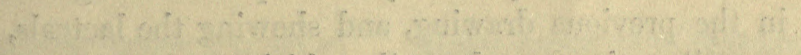

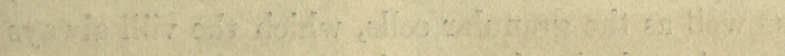

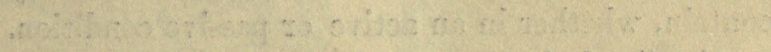

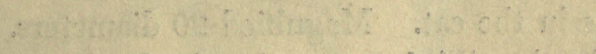

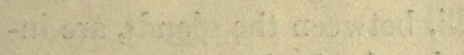

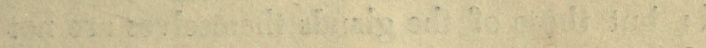

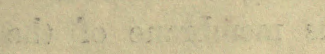

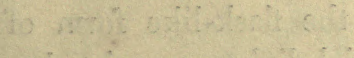

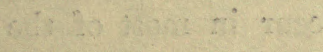

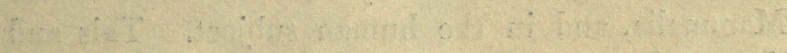

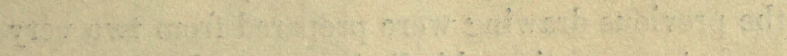

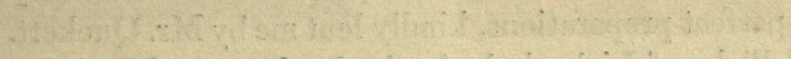

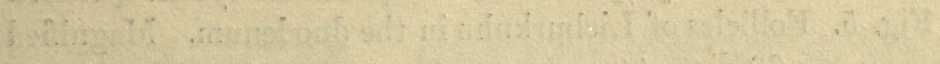

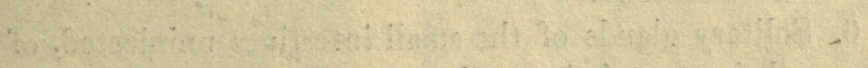

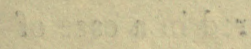




\section{Plate LII.}

Fig. 1. Villi, showing the layer of epithelial cells with which they are generally covered, especially during the intervals of digestion. Magnified 100 diameters.

Fig. 2. Ditto, uncovered by the layer of epithelium figured in the previous drawing, and showing the lacteals, as well as the granular cells, which the villi always contain, whether in an active or passive condition.

Fig. 3. Peyer's Glands in the cat. Magnified 20 diameters. The vessels in the villi, between the glands, are injected; but those of the glands themselves are not so, and this accounts for their being uncoloured.

Fig. 4. Vertical section of the mucous membrane of the ileum of the cat, showing the flask-like form of Peyer's Glands. No essential difference exists between these glands, as they occur in most of the Mammalia, and in the human subject. This and the previous drawing were prepared from two very perfect preparations, kindly lent me by Mr. Quekett.

Fig. 5. Follicles of Lieburkuhn in the duodenum. Magnified 60 diameters.

Fig 6. Solitary glands of the small intestines uninjected, of their natural size, and as they occurred in a case of muco-enterite. 

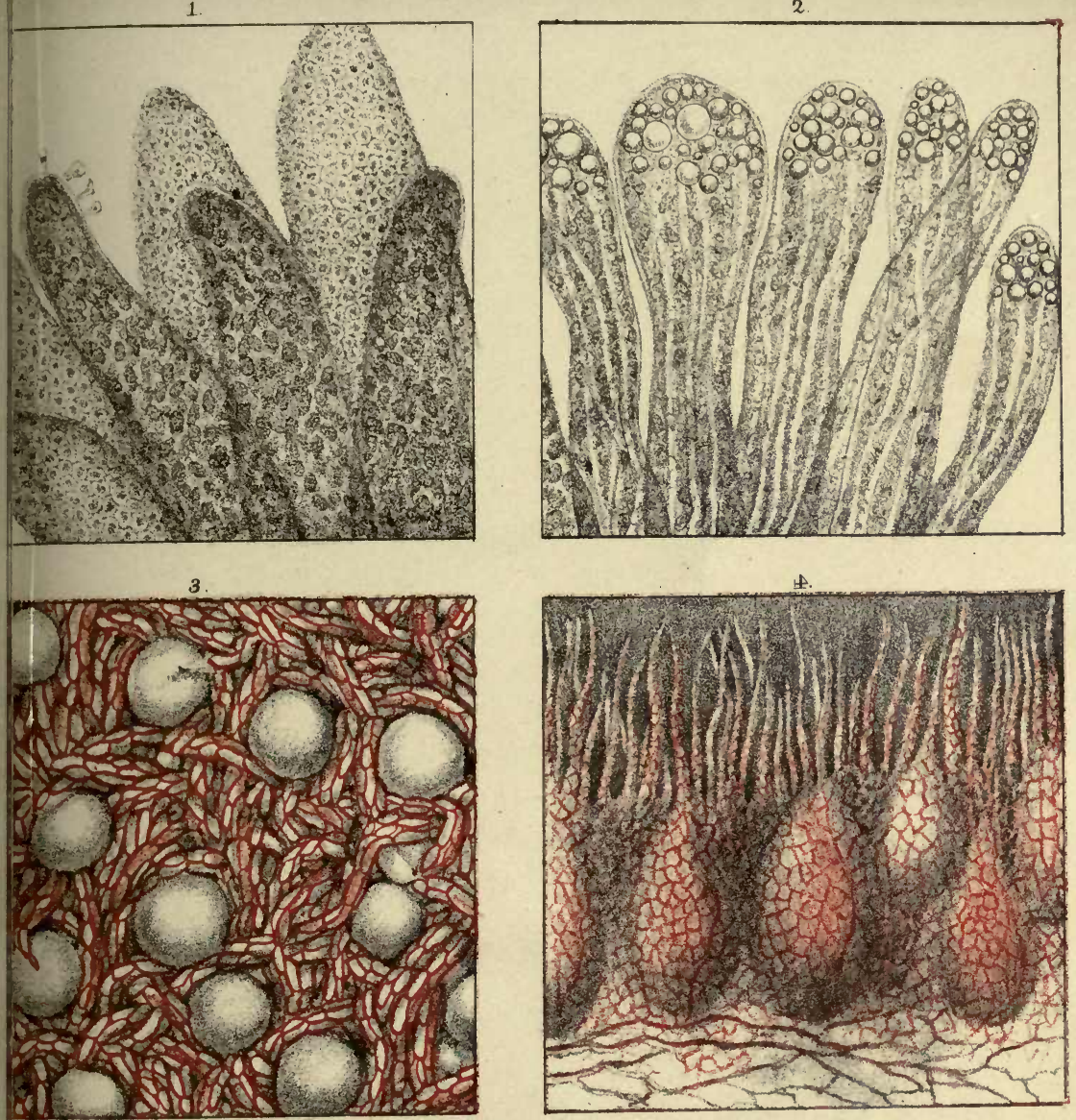

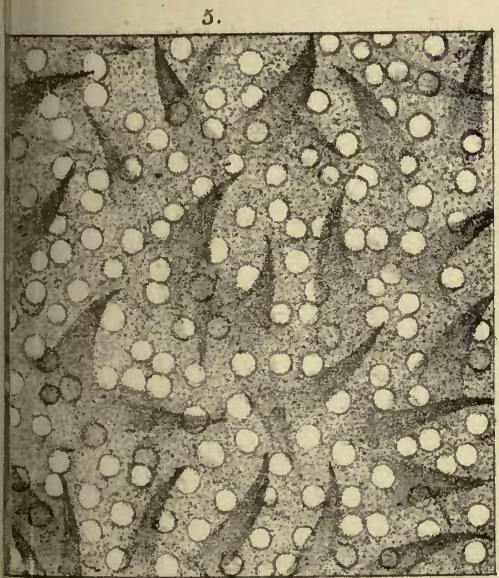

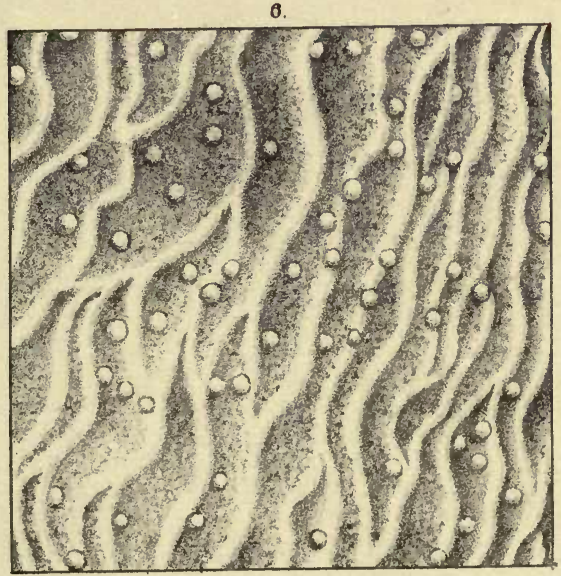

Alier, det et lith. 


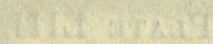

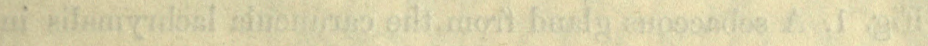

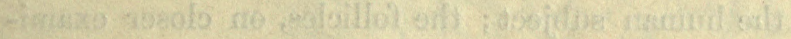

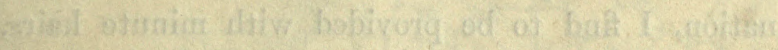

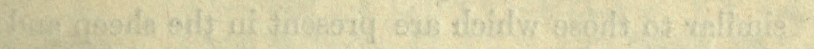

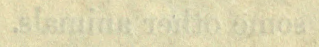

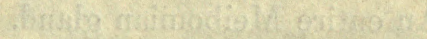

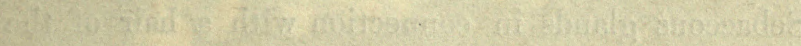

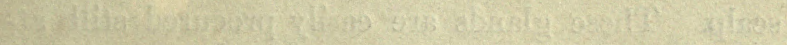

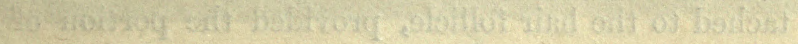

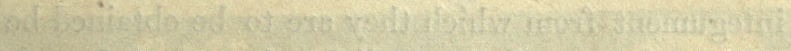

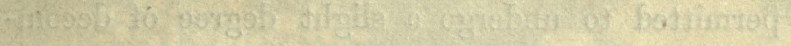
moraliog

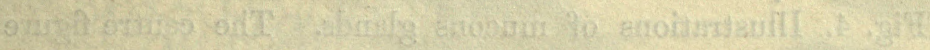

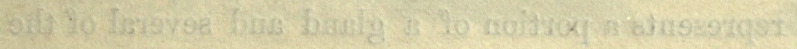

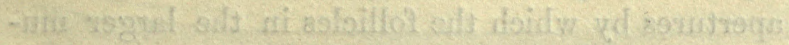

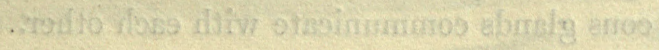




\section{Plate LIII.}

Fig. 1. A sebaceous gland from the caruncula lachrymalis in the human subject; the follicles, on closer examination, I find to be provided with minute hairs, similar to those which are present in the sheep and some other animals.

Fig. 2. An entire Meibomian gland.

Fig. 3. Sebaceous glands in connection with a hair of the scalp. These glands are easily procured still attached to the hair follicle, provided the portion of integument from which they are to be obtained be permitted to undergo a slight degree of decomposition.

Fig. 4. Illustrations of mucous glands. The centre figure represents a portion of a gland and several of the apertures by which the follicles in the larger mucous glands communicate with each other. 
Hin LIII

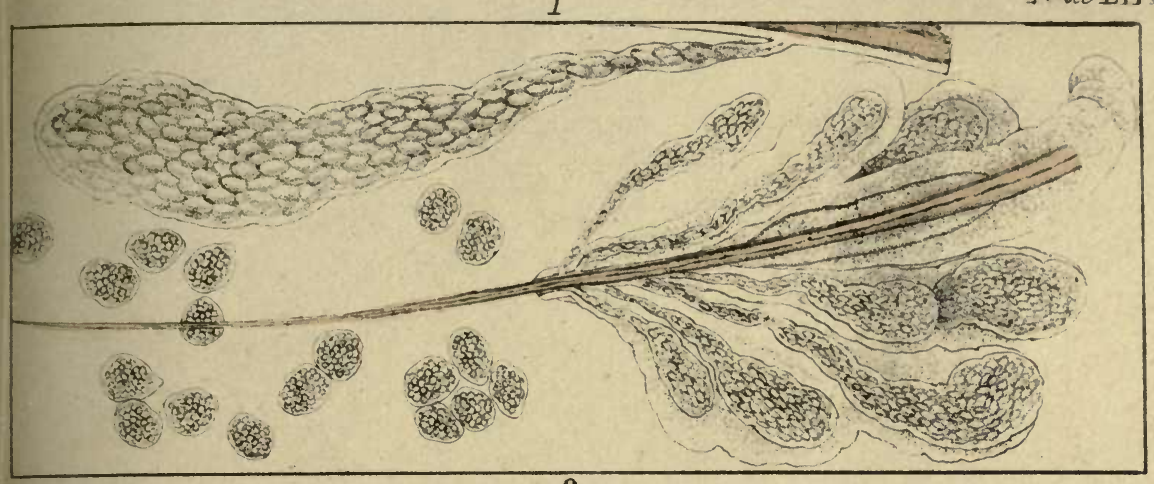

2

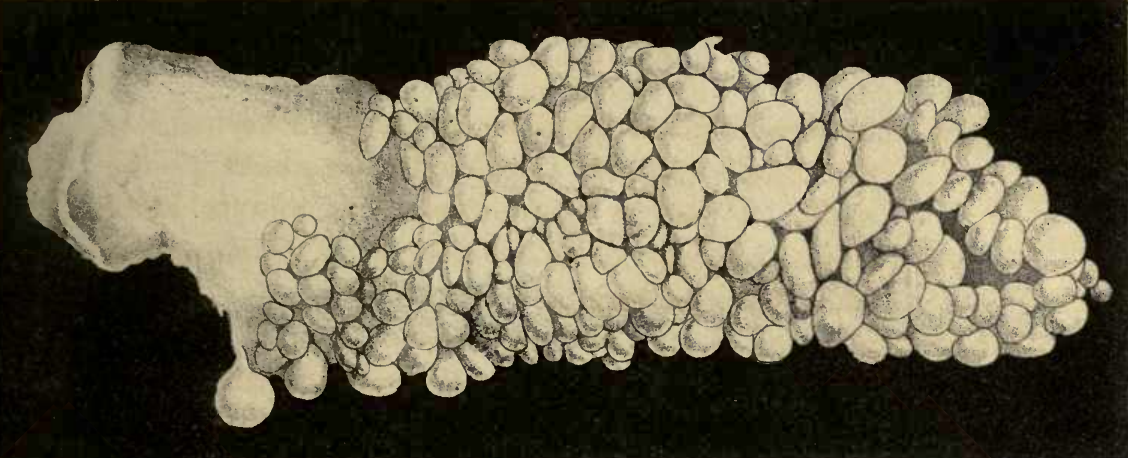

3
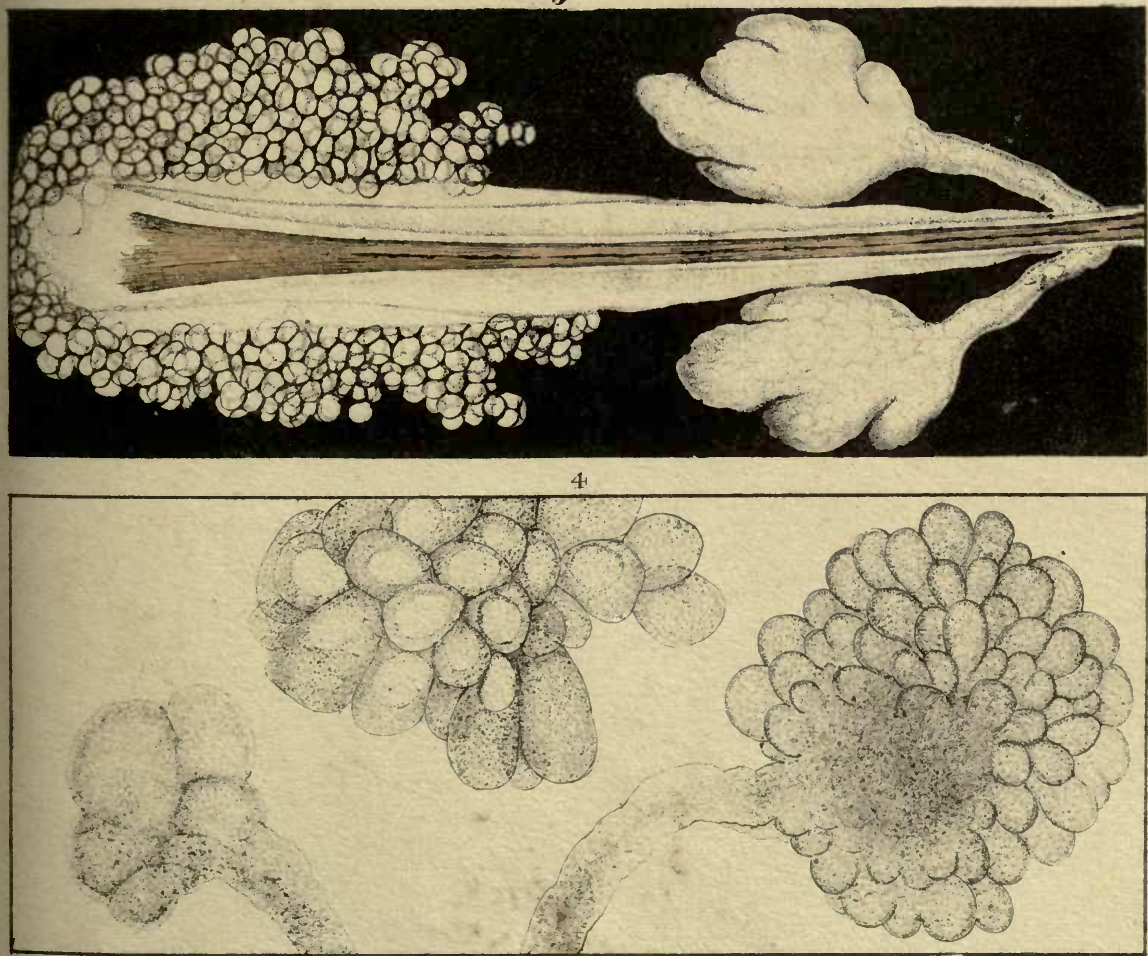



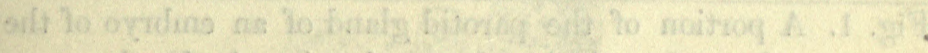

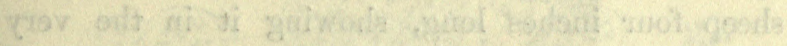

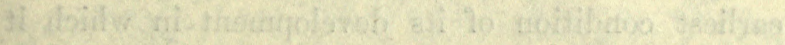

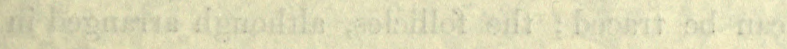

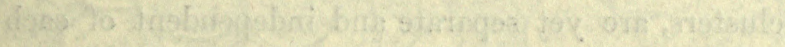

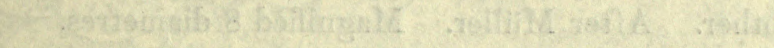

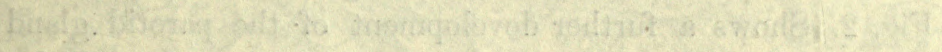

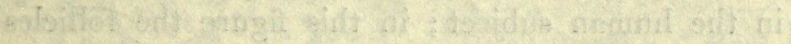

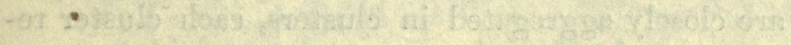

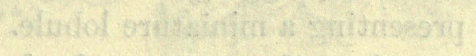

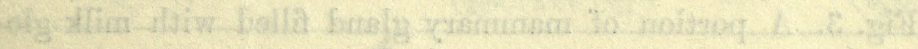
atelank

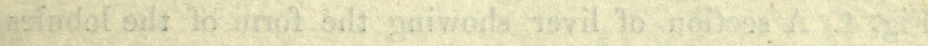

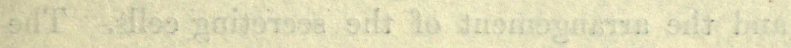

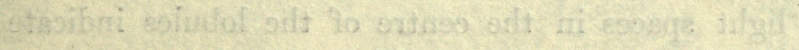

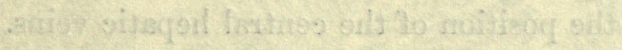

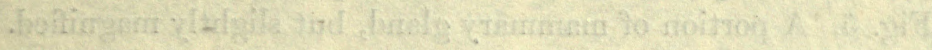

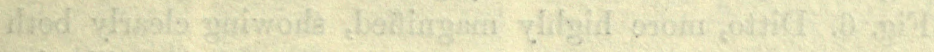

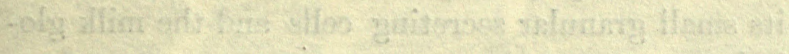

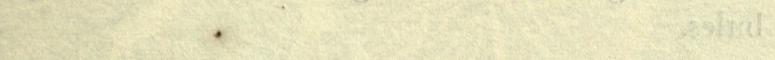




\section{Plate LIV.}

Fig. 1. A portion of the parotid gland of an embryo of the sheep four inches long, showing it in the very earliest condition of its development in which it can be traced; the follicles, although arranged in clusters, are yet separate and independent of each other. After Müller. Magnified 8 diametres.

Fig. 2. Shows a further development of the parotid gland in the human subject; in this figure the follicles are closely aggregated in clusters, each cluster representing a miniature lobule.

Fig. 3. A portion of mammary gland filled with milk glo. bules.

Fig. 4. A section of liver showing the form of the lobules and the arrangement of the secreting cells. The light spaces in the centre of the lobules indicate the position of the central hepatic veins.

Fig. 5. A portion of mammary gland, but slightly magnified. Fig. 6. Ditto, more highly magnified, showing clearly both its small granular secreting cells and the milk globules. 

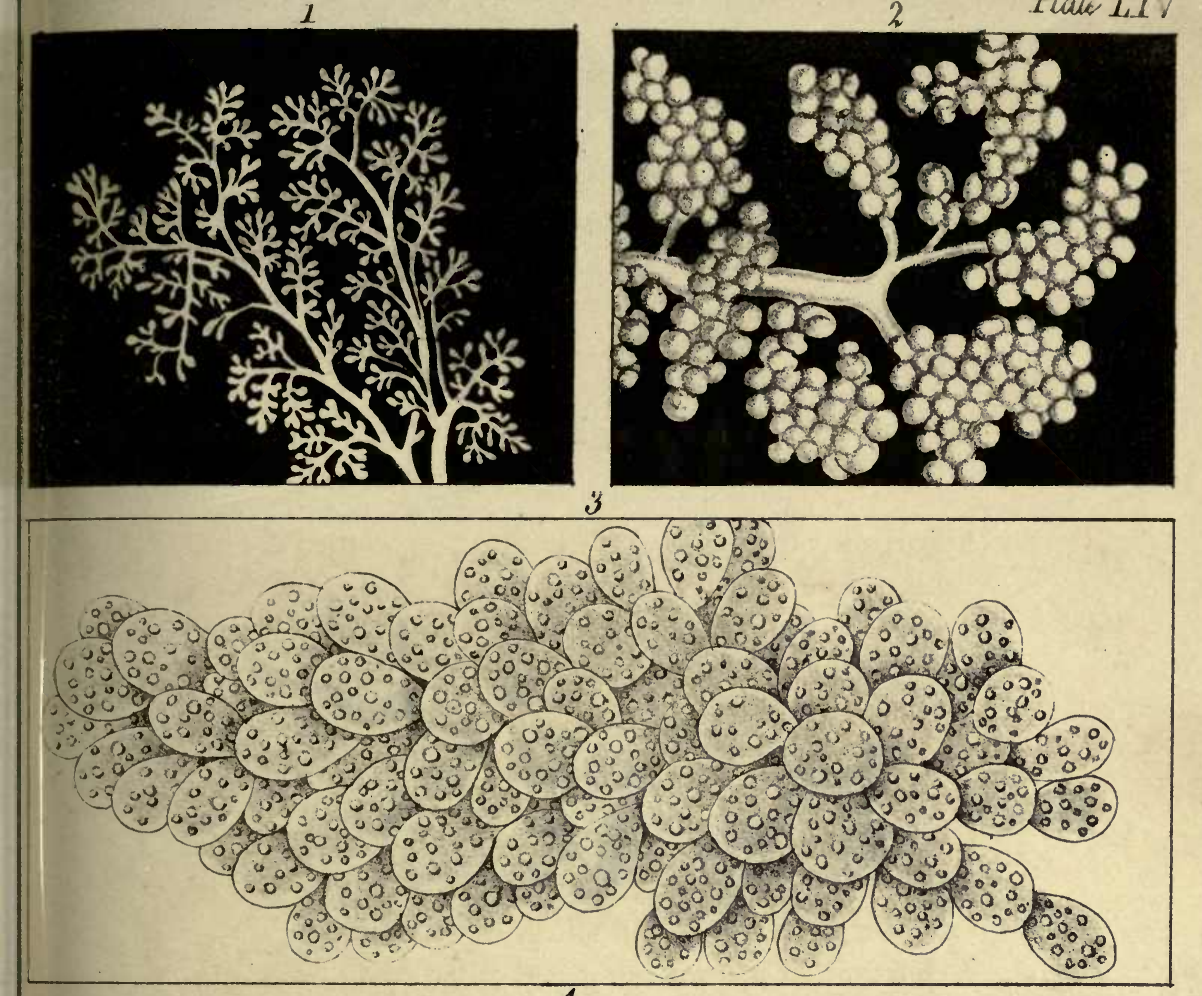

4

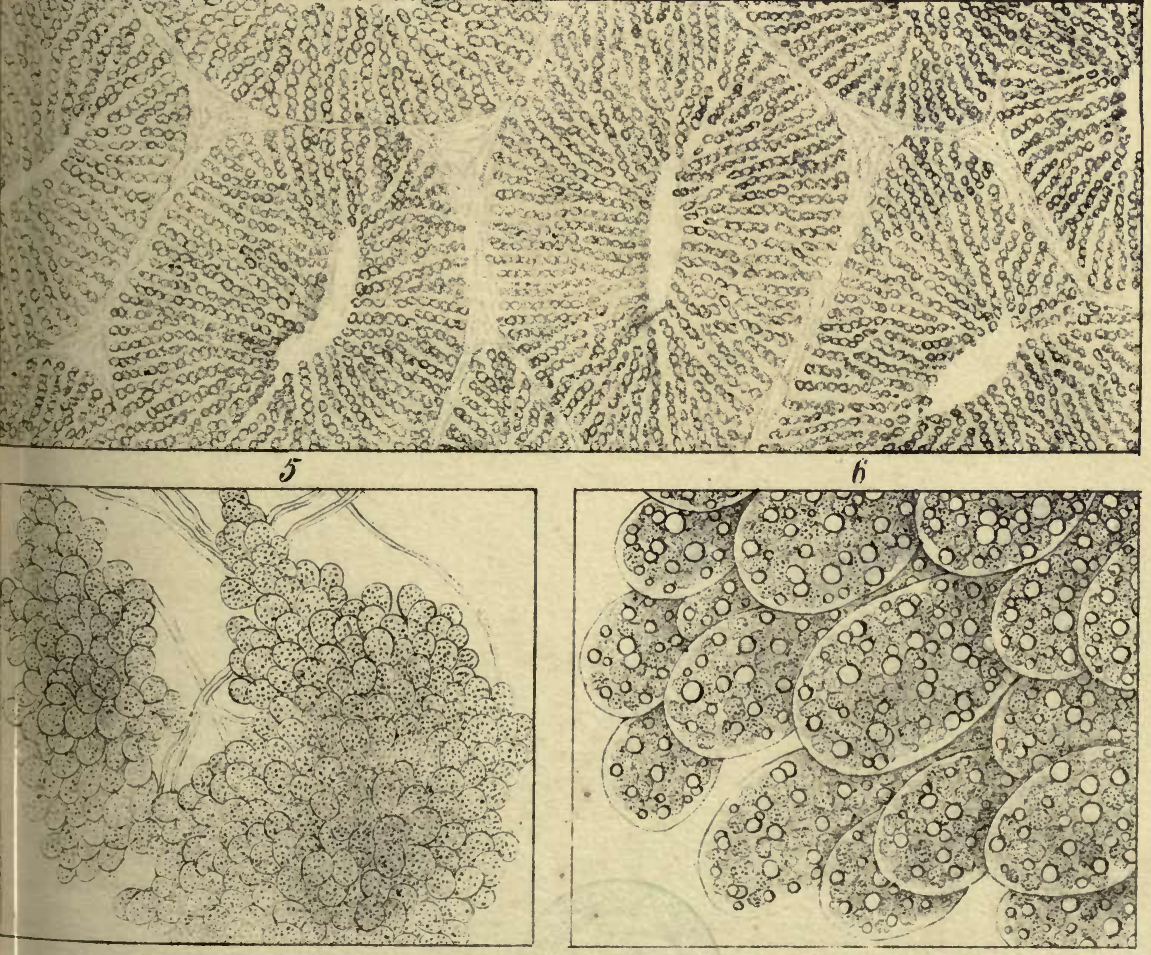





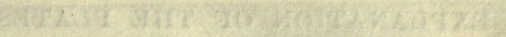

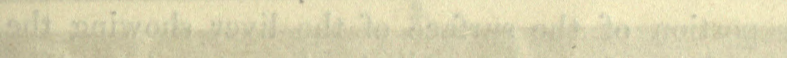
(3) -

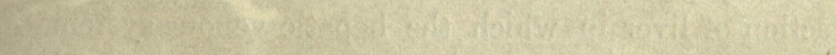

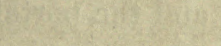

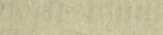

(cision:

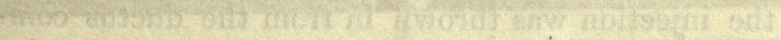

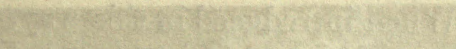

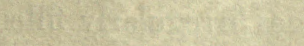

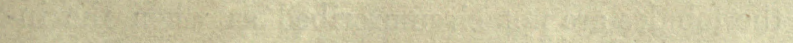

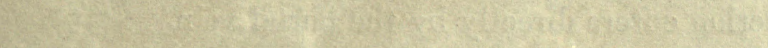

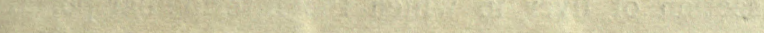

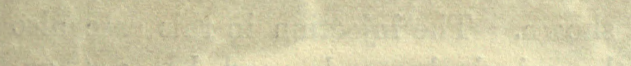

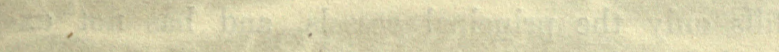

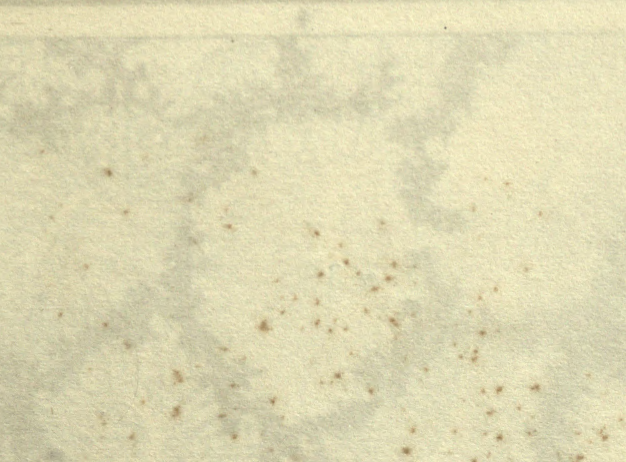




\section{Plate LV.}

Fig. 1. A portion of the surface of the liver showing the lobules and the intra-lobular hepatic veins. The injection has filled only the larger vessels, and has scarcely penetrated to the capillaries.

Fig. 2. Section of liver in which the hepatic venous system has been very completely injected, and the portal (in yellow) only slightly so. The communication between the vessels of different lobules is also well shown. Drawing made from a preparation of Dr. Hanfield Jones.

Fig. 3. Would appear to be a portion of the portal system; the injection was thrown in from the ductus communis choledochus. When introduced in this way, this system always becomes irregularly filled; and the lobules are not circumscribed as when the injection enters directly by the portal vein.

Fig. 4. A section of liver in which the interlobular portal vessels are shown. The injection in this case also fills only the principal vessels, and has not extended to the capillaries. 


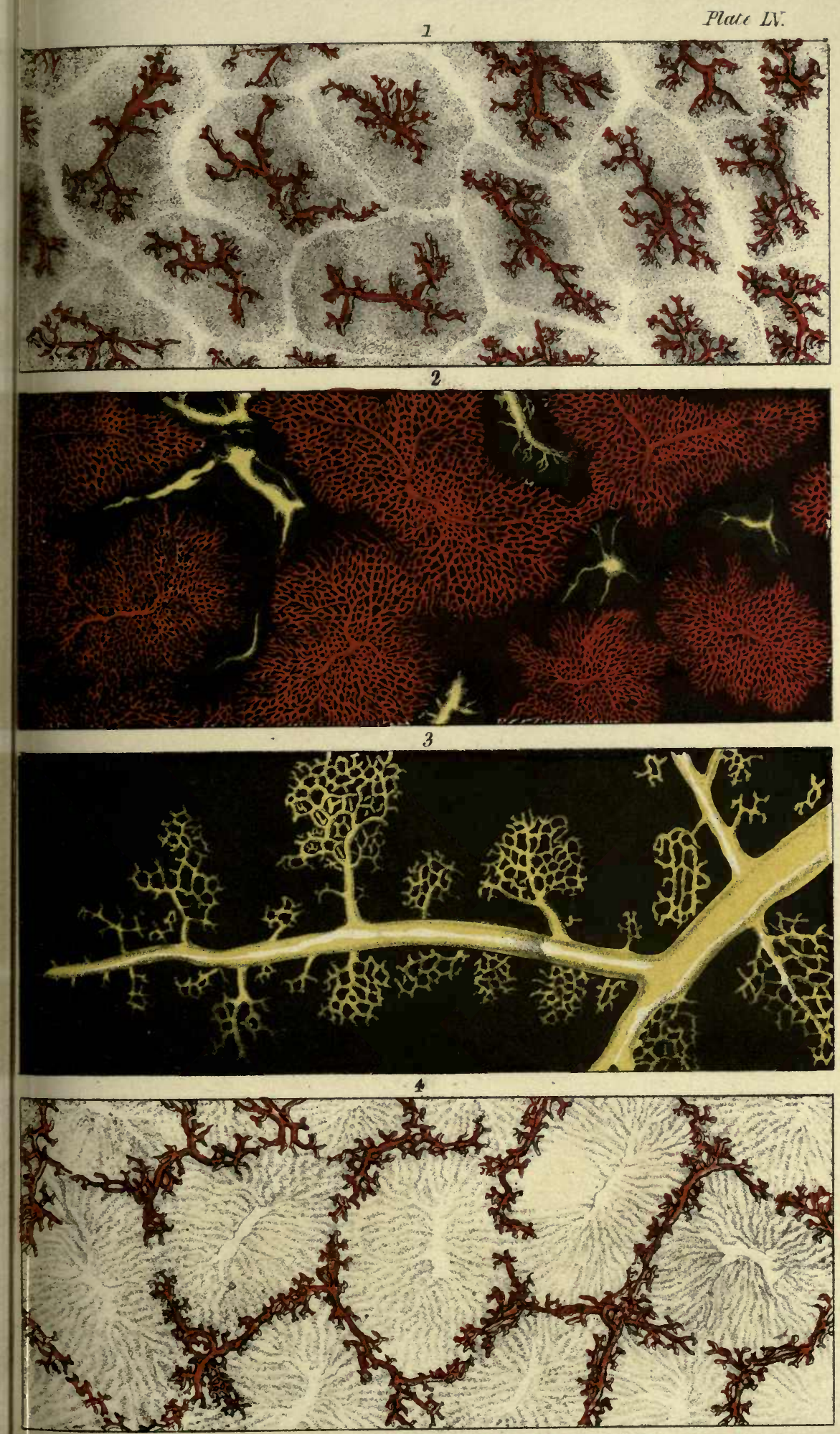




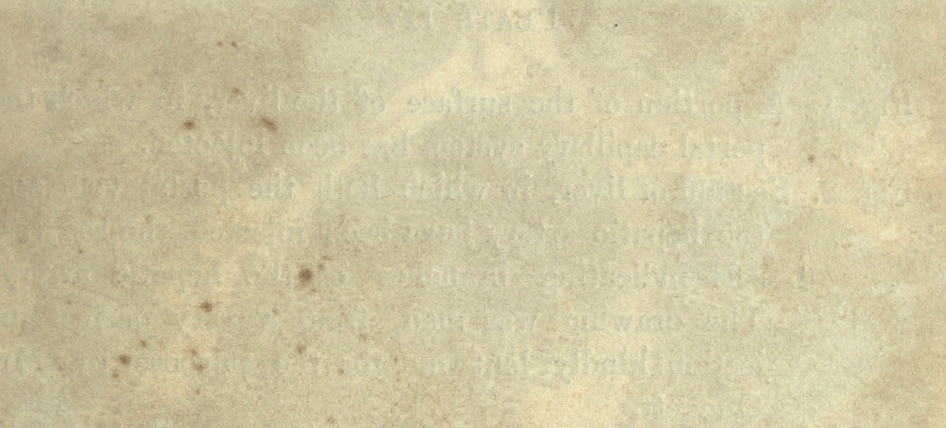

(3)

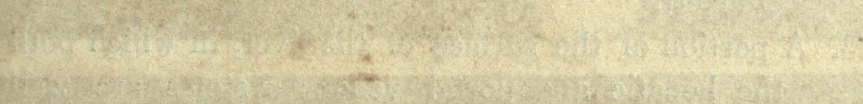
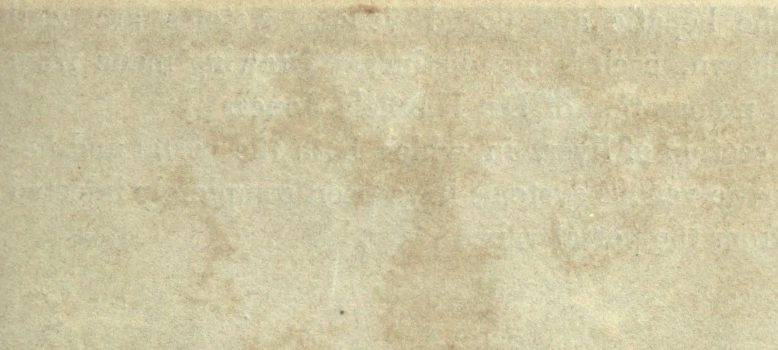
Fig. 1. A portion of the surface of the liver, in which the portal capillary system has been injected.

Fig. 2. Section of liver, in which both the portal vein and the hepatic artery have been injected, the red vessels indicating branches of the hepatic artery. The drawing was made from a very perfect injection kindly lent me for the purpose by Mr. Quekett.

Fig. 3. A portion of the surface of the liver, in which both the hepatic and portal venous systems are well shown, each being distinct. Drawing made from a preparation of Dr. Hanfield Jones.

Fig. 4. A section of liver, in which both the portal and hepatic venous systems have been completely injected from the portal vein. 


\section{Plate LVII.}

Fig. 1. A terminal biliary duct, copied from a drawing of Dr. H. Jones.

Fig. 2. Secreting cells of the liver. The group lettered $a$ represents the cells in the usual condition in which they are met, when submitted to observation: in $b$, the cells are gorged with bile, while in $c$, they contain numerous fat or oil globules.

Fig. 3. Concretions or calculi from the prostate gland.

Fig. 4. $a$ represents an hitherto undescribed form of tubular gland occurring in the region of the human axilla in close connection with the large sudoriferous - glands which are there met with. It differs from these last, however, in several particulars, but principally in the smaller calibre of the tubes, and the presence (clearly shown by the action of acetic acid) of innumerable nuclei in the walls of the tubes, and of which these would appear to be principally constituted. In $b$ and $c$, the differences in the size and structure of the tubes in the two glands are shown.

Fig. 5. Ceruminous glands. I cannot detect the slightest difference between these glands and ordinary sudoriferous glands, with which, it would appear, they must be considered to be identical. 


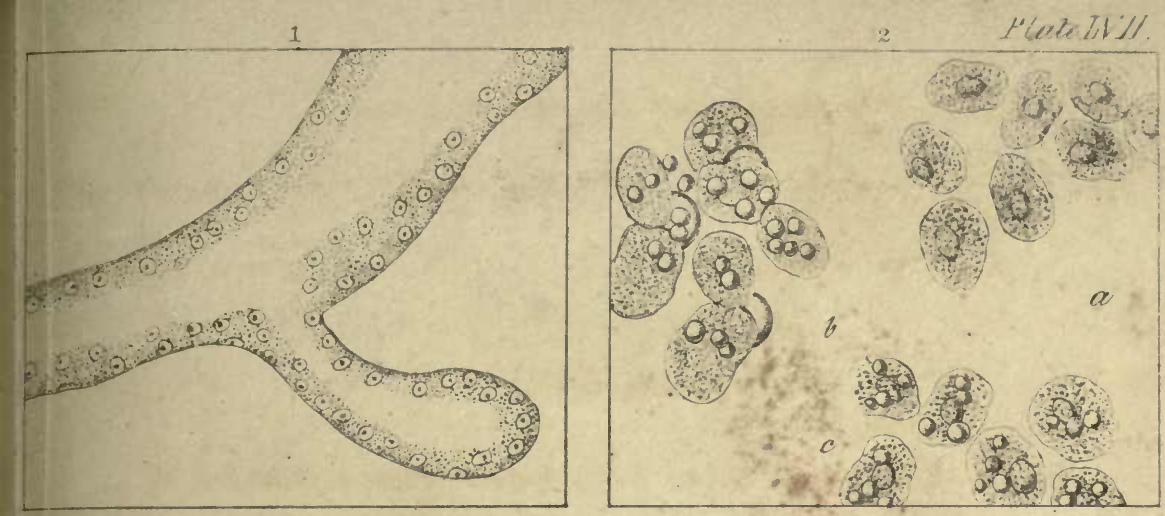

3
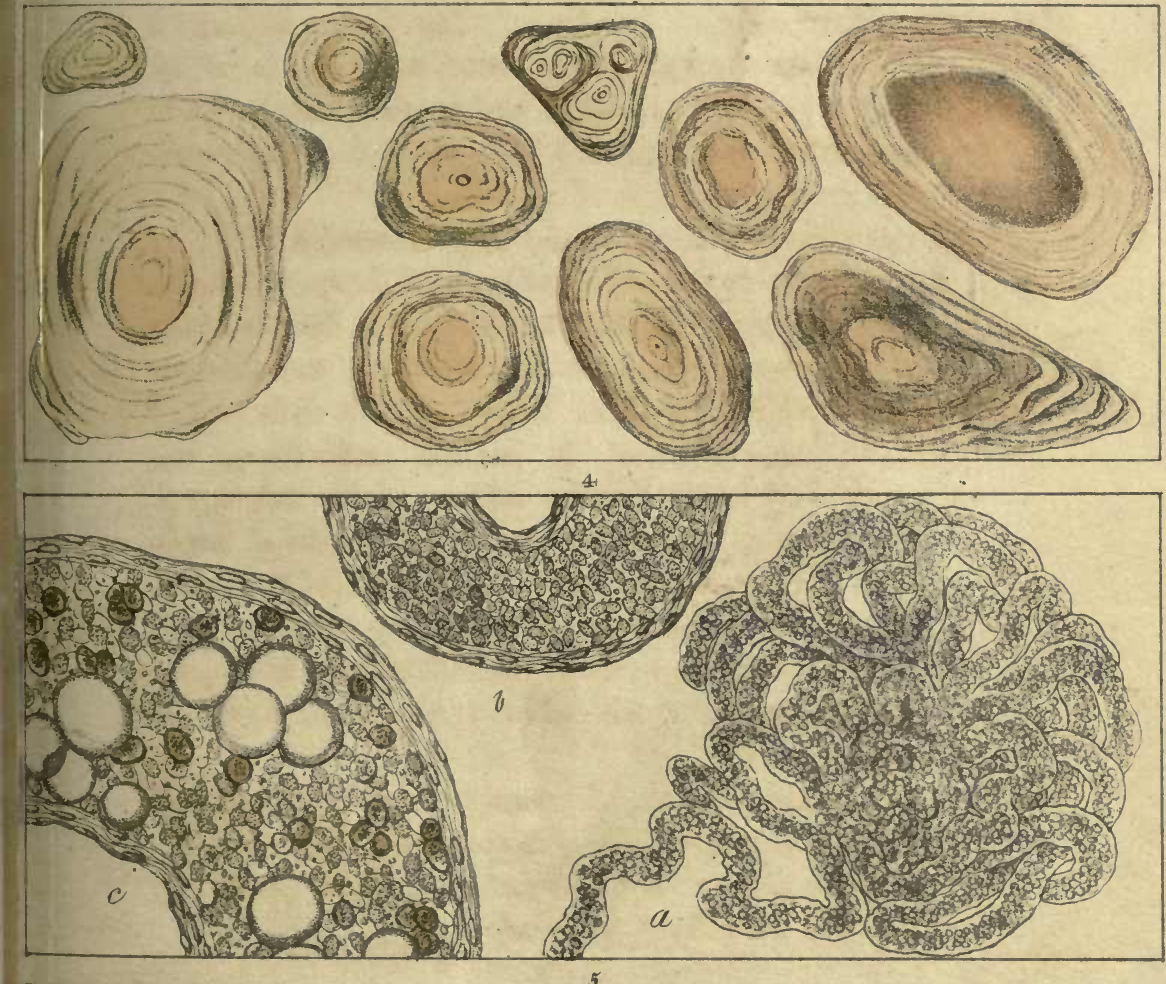

5

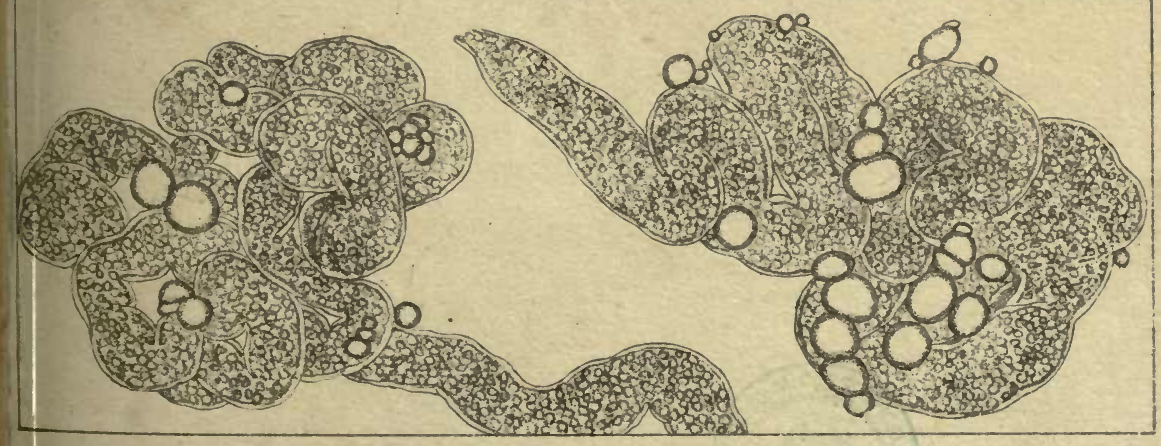




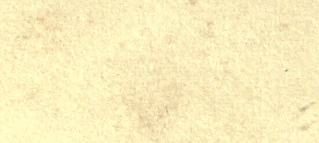




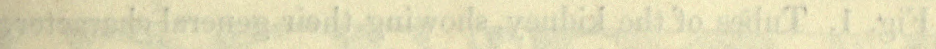

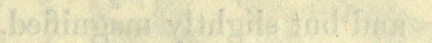

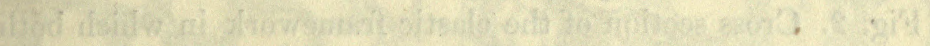

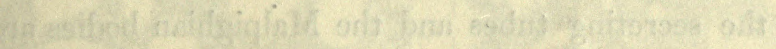

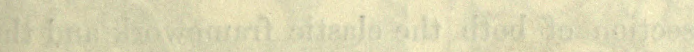

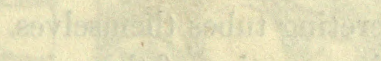

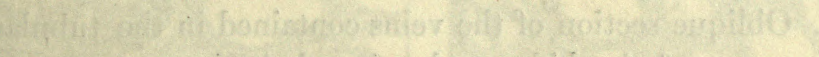

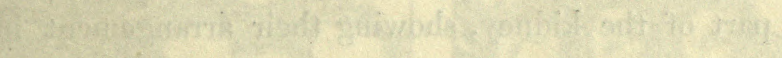
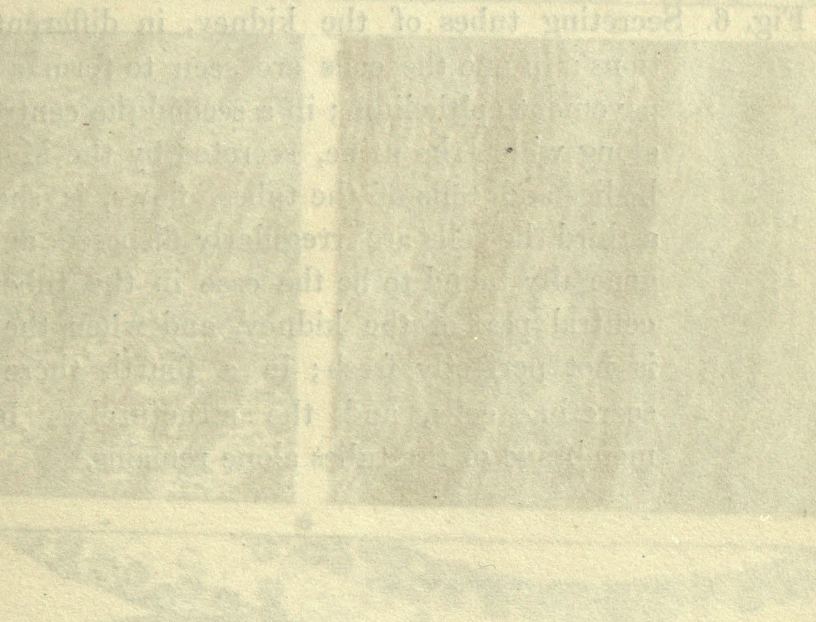

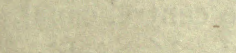

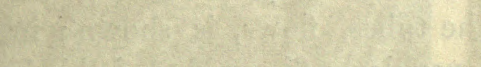

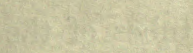

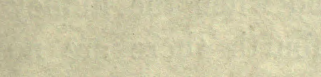

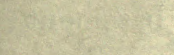

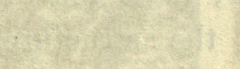




\section{Plate LVIII.}

Fig. 1. Tubes of the kidney, showing their general character, and but slightly magnified.

Fig. 2. Cross section of the elastic framework in which both the secreting tubes and the Malpighian bodies are enclosed.

Fig. 3. Cross section of both the elastic framework and the secreting tubes themselves.

Fig. 4. Oblique section of the veins contained in the tubular part of the kidney, showing their arrangement in sets.

Fig. 5. The same vessels seen lengthways.

Fig. 6. Secreting tubes of the kidney, in different conditions: in one the cells are seen to form a regular pavement epithelium; in a second the central canal, along which the urine, secreted by the Malpighian bodies and cells of the tubes, flows, is shown; in a third the cells are irregularly disposed, and this is generally found to be the case in the tubes of the central part of the kidney, and when the kidney is not perfectly fresh; in a fourth there are no secreting cells, and the structureless basement membrane of the tubes alone remains. 


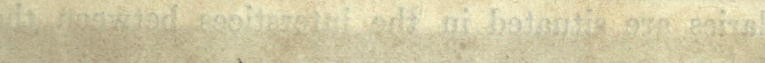

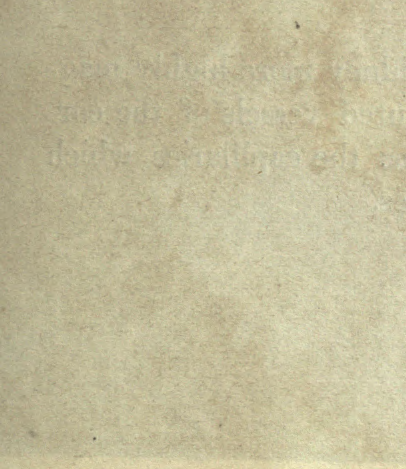


Fig. 1. Longitudinal section of kidney, showing the corpora Malpighiana.

Fig. 2. Uriniferous tubes of a bird (Gallus indicus), showing their pinnatifid arrangement. Drawing made from a preparation of Professor Hyrtl, in the possession of the Microscopical Society of London.

Fig. 3. Corpora Malpighiana of the horse. Drawing made from an injected preparation by Professor Hyrtl.

Fig. 4. Vessels of the surface of the kidney. The capillaries are situated in the interstices between the tubes.

Fig. 5. A transverse section of the kidney more highly magnified, showing the convoluted vessels of the corpora Malpighiana, as well as the capillaries which encircle the uriniferous tubes. 
$10 \quad P l a l e L 1.1$

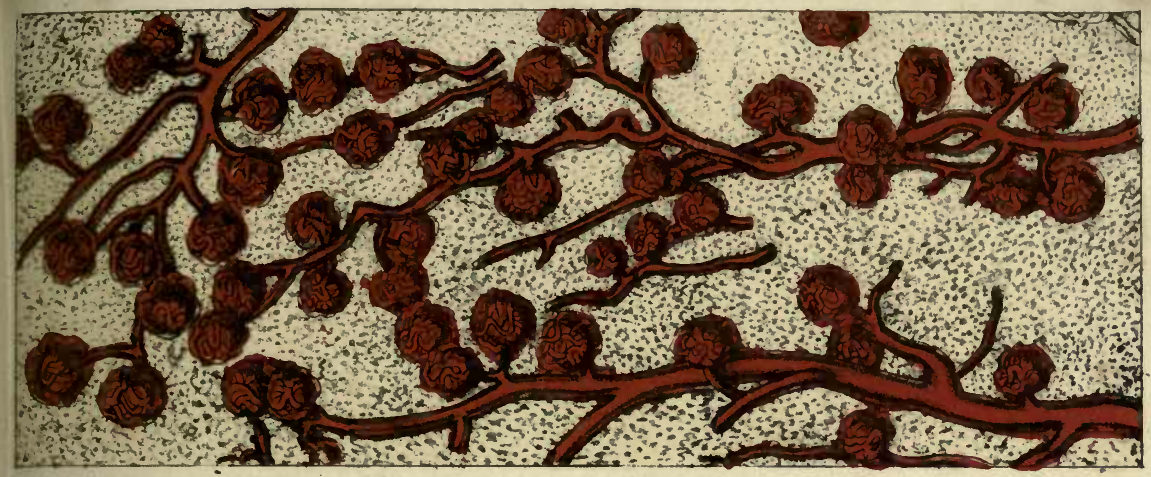

\section{2}

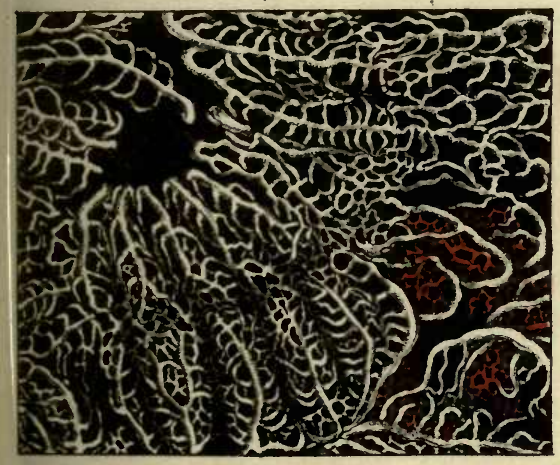

4
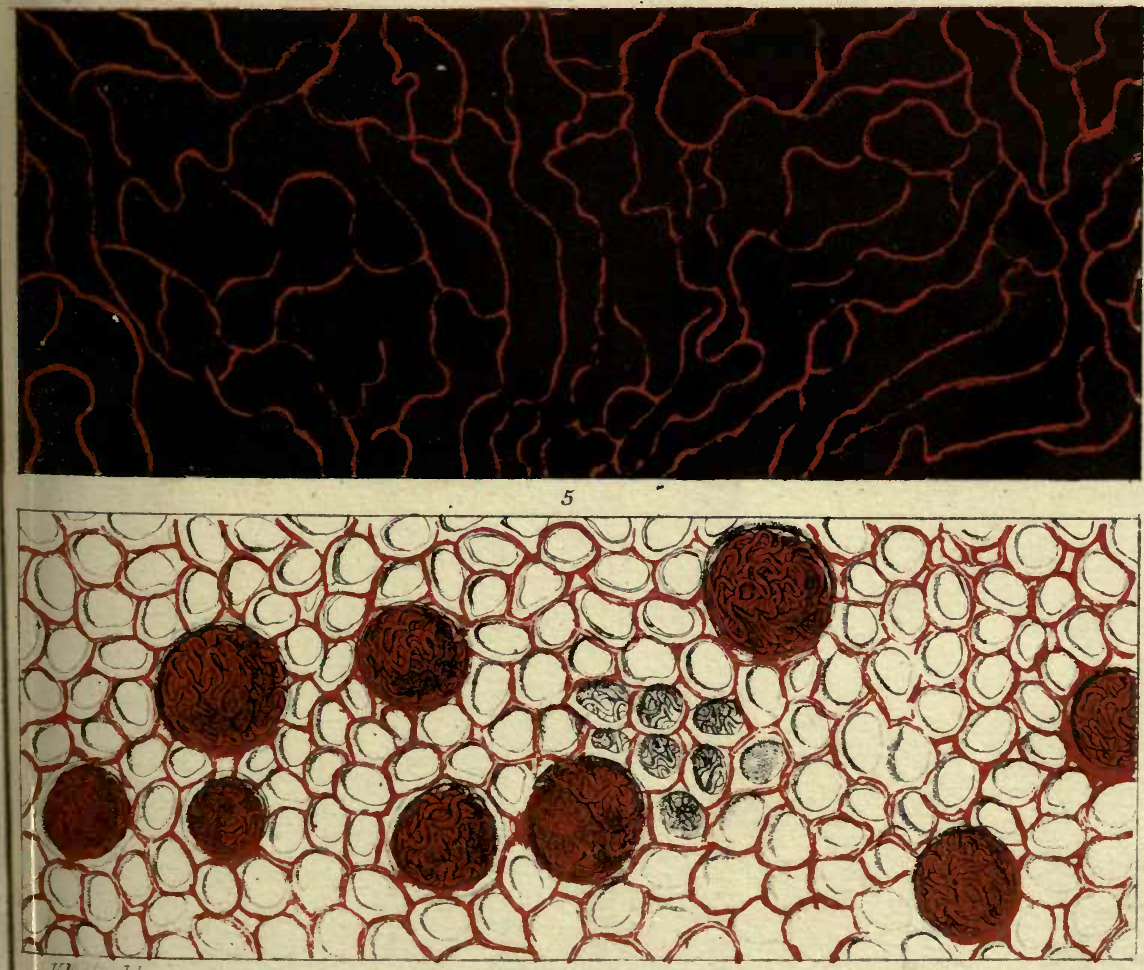


\section{Plate LX.}

Fig. 1. Tubes of the testis slightly magnified, showing their general appearance and arrangement.

Fig. 2. Uninjected corpora Malpighiana. $a$ is enveloped in its own proper capsule, while in $b$ this has been removed. Additional observations have convinced me that these complicated bodies are invested, in addition to the thick elastic covering spoken of in the text, with an inner and much thinner membrane: and that it is this which is to be regarded as the proper Malpighian capsule. This covering, I conceive, is conveyed to each Malpighian body by the afferent artery, from which it is reflected over the Malpighian dilatation and plexus of vessels; and it may often be seen as a distinct structure partially separated from the other constituents of a Malpighian body. The framework of elastic tissue, which invests on every side the tubes and Malpighian bodies, is everywhere continuous by its outer surface, that of one tube with that of the neighbouring tubes, and that of the Malpighian body is also continuous with that of the tubes which surround this Malpighian body. On the other hand, the proper and thin Malpighian capsule is smooth on its outer surface, and not connected by this surface with any other structure, save the afferent and efferent vessels along which it is continued. This general continuity of the elastic framework is well shown in Plate LVIII. fig. 2.

Fig. 3. $A$, a Malpighian body, more highly magnified, displaying innumerable small oval and granular cells. 


\section{EXPLANATION OF THE PLATES.}

The majority of these, I am now disposed to think, are contained in the walls of the vessels constituting the Malpighian plexus. The figure $b$ is after Bowman, and shows the afferent artery and the efferent vein of the Malpighian tuft, also the connection of the tube with the Malpighian body itself; $c$, loose epithelial cells of the tubes.

Fig. 4. Tube of the testis, more highly magnified, displaying the innumerable granular cells which fill the tube as well as the structure of the tube itself. 


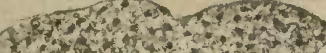

1.

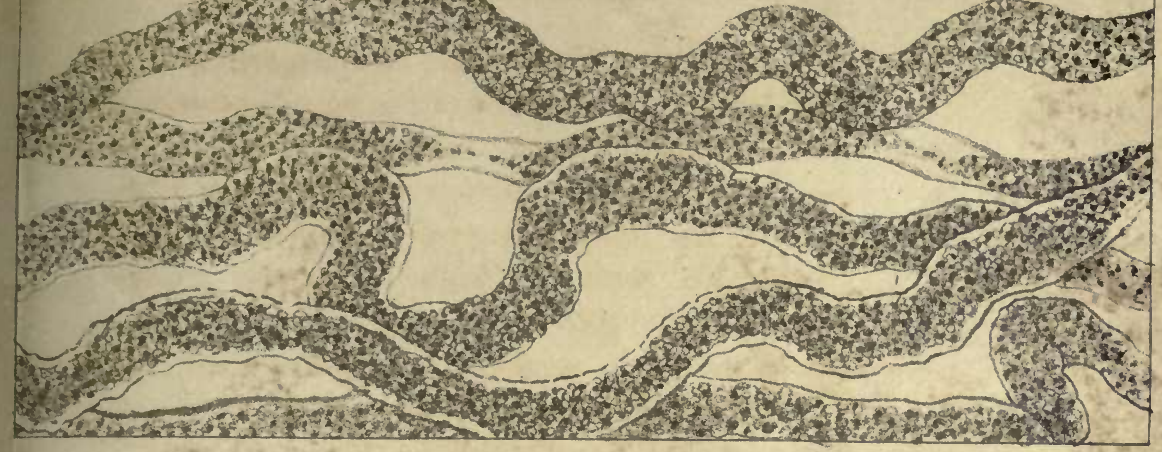

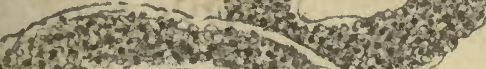





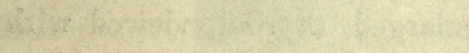

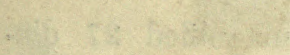

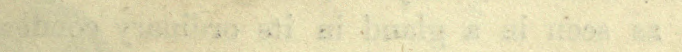

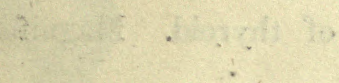

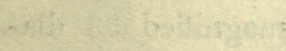

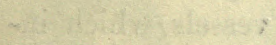

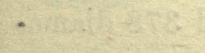




\section{EXPLANATION. OF THE PLATES.}

\section{Plate LXI.}

Fig. 1. Vessels of thyroid gland. 18 diameters.

Fig. 2. Vesicles of slightly enlarged thyroid, viewed with a lens only.

Fig. 3. Ditto of same, magnified 40 diameters.

Fig. 4. Ditto of same, magnified 67 diameters, showing the fibrous structure of their walls, and their cellular and nuclear contents.

Fig. 5. Lobes and vesicles of thyroid, magnified 27 diameters, as seen in a gland in its ordinary condi. tion.

Fig. 6. Granular nuclei of vesicles of thyroid. Magnified 378 diameters.

Fig. 7. Two follicles of thymus gland, magnified 33 diameters, showing the plexus of vessels which invests them.

Fig. 8. A portion of the capsule of thymus, magnified 54 diameters, showing the ternary disposition of the vessels.

Fig. 9. Granular nuclei and simple cells with fibrous. tissue of thymus. Magnified 378 diameters.

Fig. 10. Compound cells of thymus. Magnified 378 diameters. 
Plaze IXI.

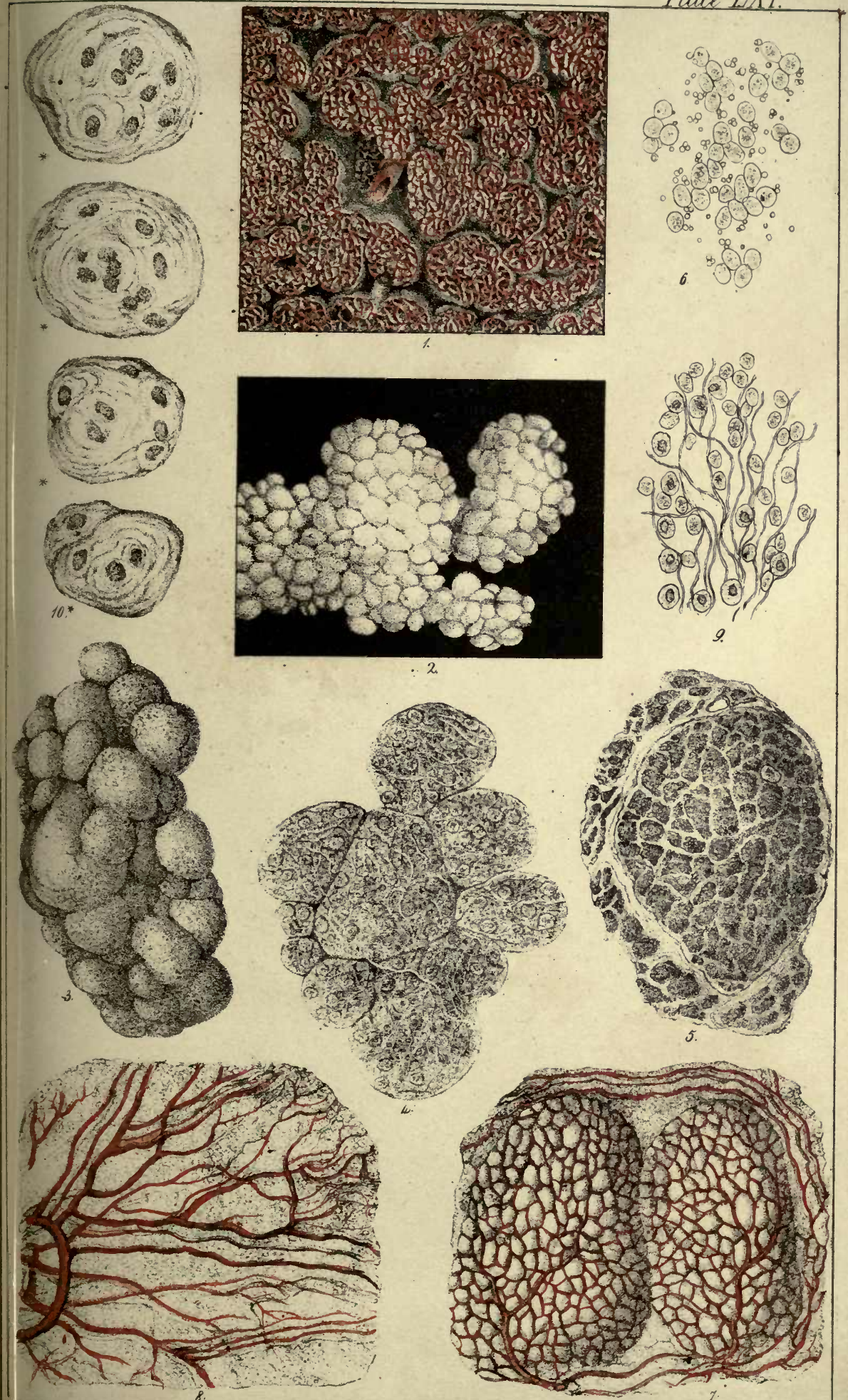




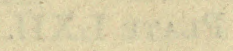




\section{Plate LXII.}

Fig. 1. Granular nuclei, blood-vessels, and fibro-elastic tissue of spleen. Magnified 378 diameters.

Fig. 2. Plexus of vessels on the surface of supra-renal capsule. Magnified 54 diameters.

Fig. 3. A. Tubes of supra-renal capsule. 90 diameters. B. Nuclei, parent cells, and molecules of the same. 378 diameters.

Fig. 4. Vessels of the foctal portion of the placenta. Magnified 54 diameters. These are seen to terminate in the villi in loops.

Fig. 5. Ditto of the supra-renal capsule, showing the plexus on the surface of the organ, the long intertubular vessels, and the central plexus. 90 diameters. 


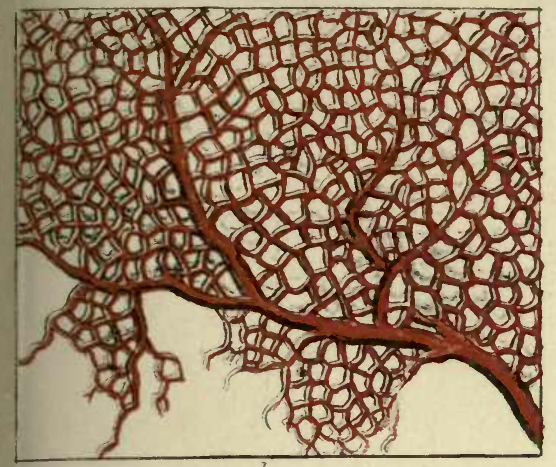

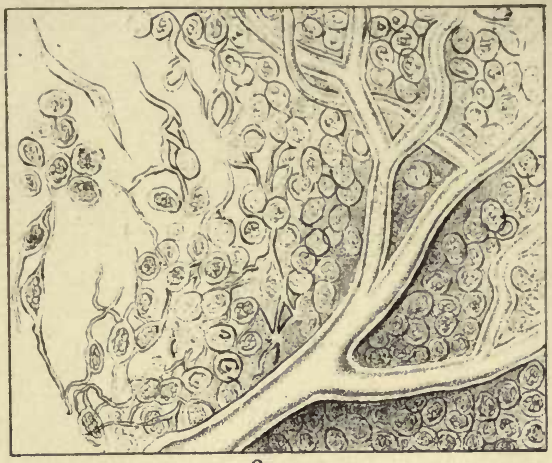

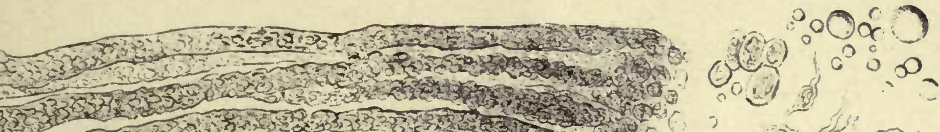

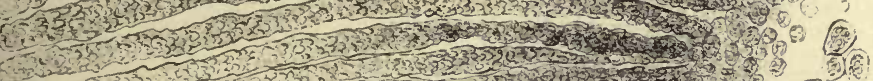

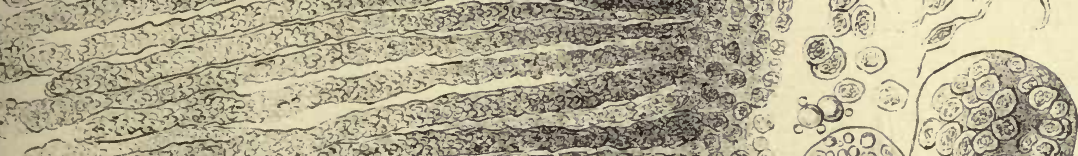

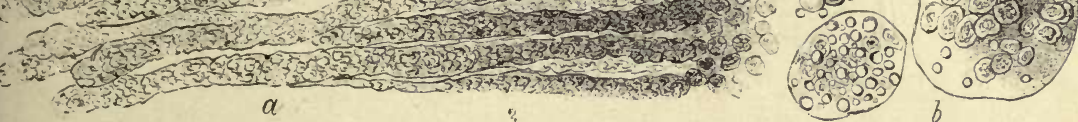
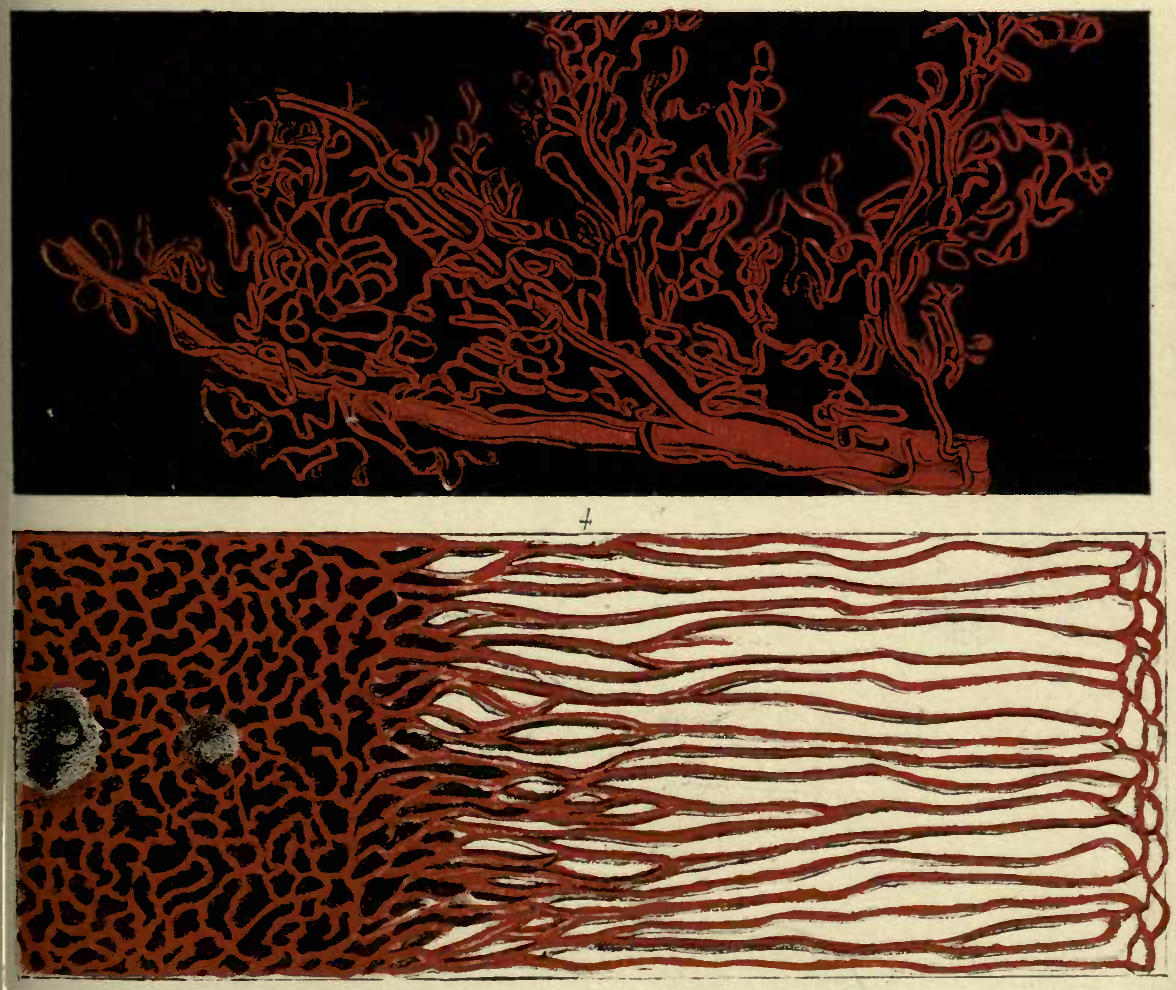




\section{Plate LXIII.}

Fig. 1. Epidermis of palm of hand, magnified 40 diameters, showing its disposition in ridges, and the apertures of the sudoriferous glands.

Fig. 2. Epidermis of the back of the hand, magnified to the same extent, showing its furrows, hairs, and apertures of sudoriferous ducts.

Fig. 3. Papillæ of palm of hand. Magnified 54 diameters.

Fig. 4. Ditto of back of hand. Magnified to the same extent.

Fig. 5. Epidermis of palm of hand, seen upon its under surface, showing pits or depressions for the reception of the papillæ, and the ducts of the sudoriferous glands. Magnified 54 diameters.

Fig. 6. Epidermis of the back of hand, viewed upon its under surface as a transparent object, and showing depressions for the papillæ and the ducts of the sudoriferous glands. Magnified 54 diameters.

Fig. 7. Blood-vessels of the papillæ of the palm of the hand, a single loop corresponds to each papilla. Magnified 54 diameters.

Fig. 8. Ditto of the back of the hand. Magnified 54 diameters. 

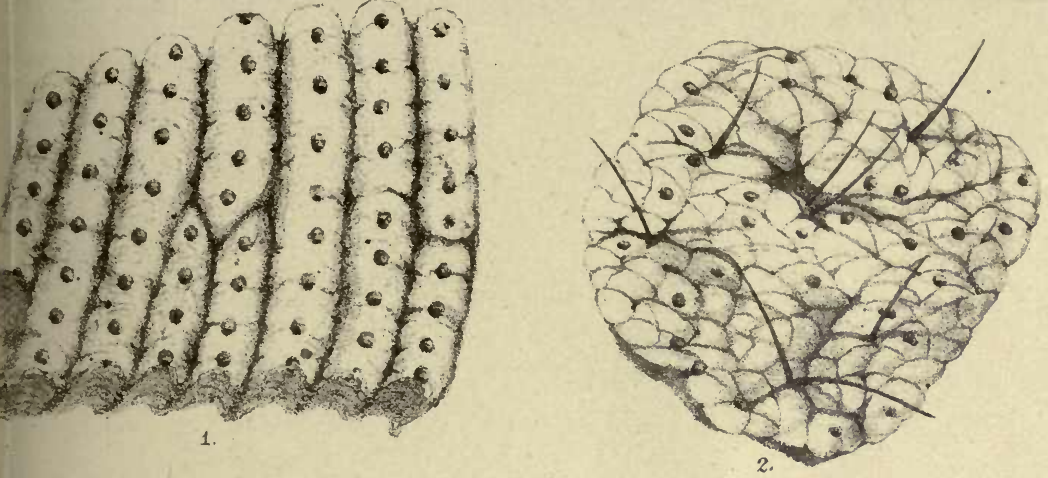

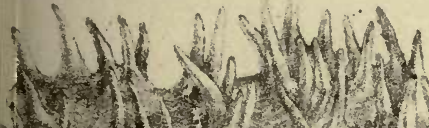

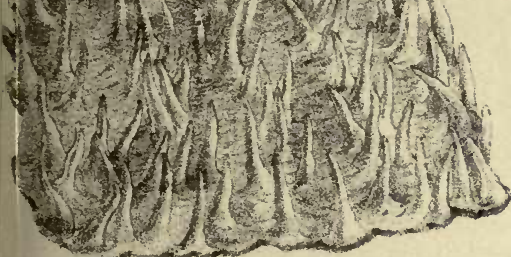

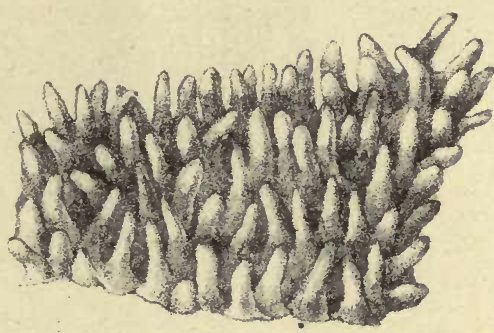

3

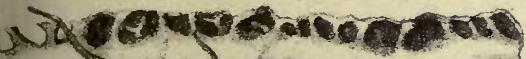

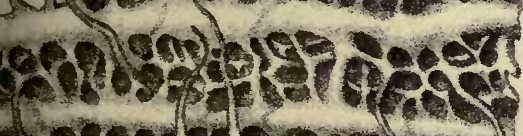

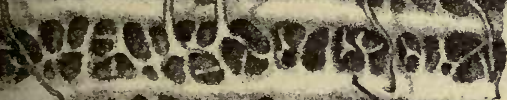

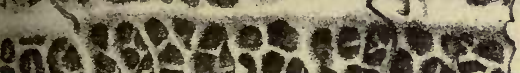

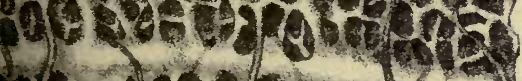

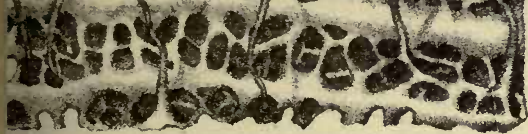

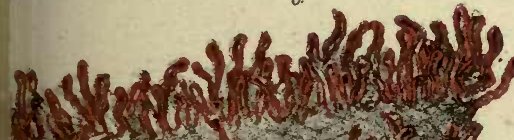

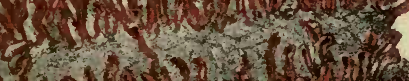

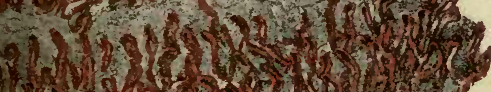

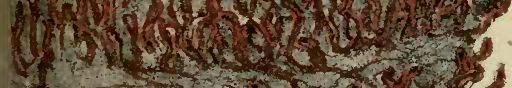

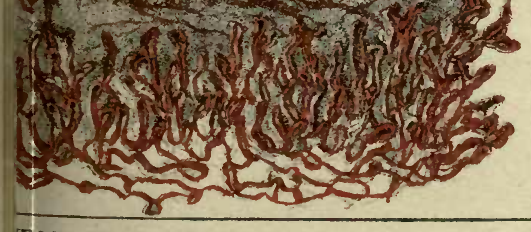

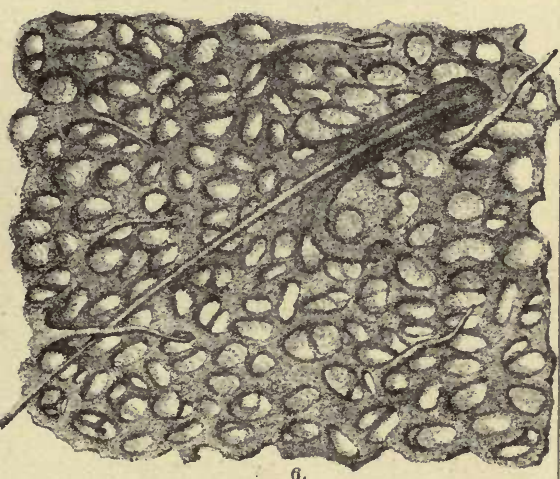

20 tring restipin 1 aspanst

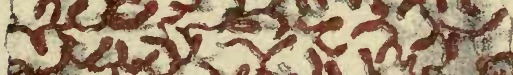

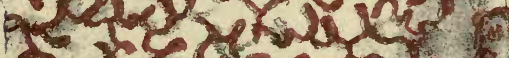
3 -n ther.t. h. 32, 5.9.

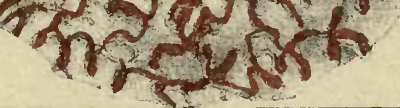





\section{Plate LXIV:}

Fig. 1. Filiform papillæ of the tongue near its centre, with epithelial appendages attached. Magnified 41 diameters.

Fig. 2. Ditto of same near its apex, with epithelial appendages attached; these are seen to be much shorter than in the previous case. Magnified 27 diameters.

Fig. 3. Ditto near the apex of the tongue, with the epithelium removed, showing their cupped form, and the arrangement and number of the secondary papillæe around their edges. Magnified 27 diameters.

Fig. 4. Ditto near the centre of the tongue, in which situation the secondary papillæ are seen to be much longer and more slender than in the previous figure, their apices falling together, and so obscuring the excavation in the centre of each filiform papilla. Magnified 31 diameters.

Fig. 5. Filiform and fungiform papillæ of the tongue, deprived of their epithelium. The size, form, and structure of the fungiform papillæ are well shown, as well as the simple papillæ situated in the fossa around the base of one of the fungiform papillæ. Magnified 27 diameters.

Fig. 6. Filiform papillæ; some deprived of their epithelial processes, others still retaining them. In the centre of the figure two filiform papillæ may be seen occupying the position of a fungiform papilla, being situated in a fossa studded with simple papillæ. 27 diameters.

Fig. 7. The centre of this figure represents a peculiar form of compound papillæ, occupying the position of a $x 4$ 
fungiform papilla, but intermediate in structure between it and a filiform papilla. 27 diameters.

Fig. 8. Filiform papillæ, showing their tubular form, with the epithelial processes partially removed, and exhibiting numerous simple papillæ placed between the compound ones. 27 diameters. 


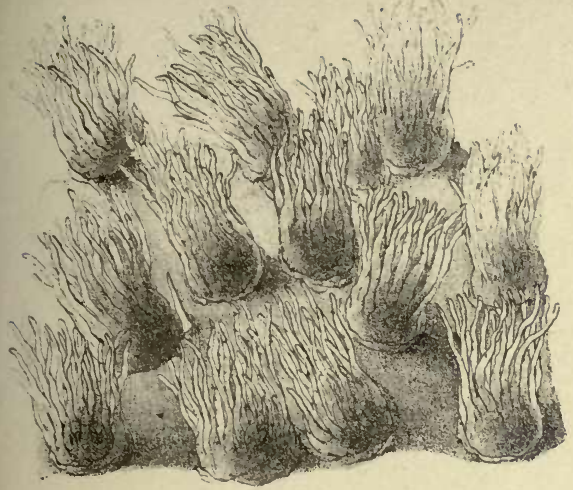

and Find 1410 3 int 3 , 35

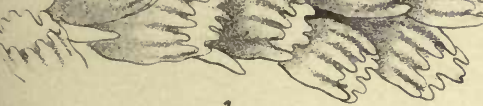

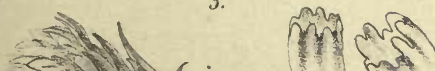
$-5=-11$ man ए5

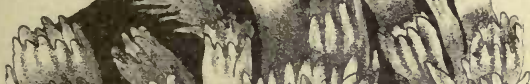

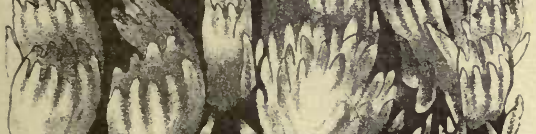
4a. 24 2. noush

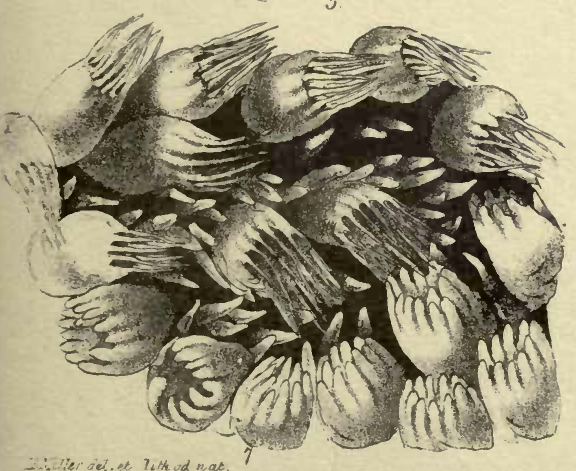

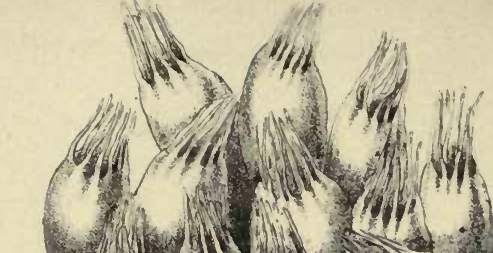

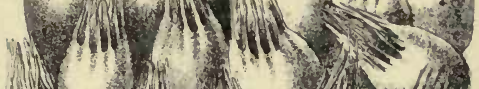

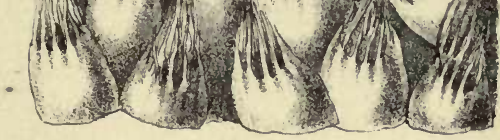

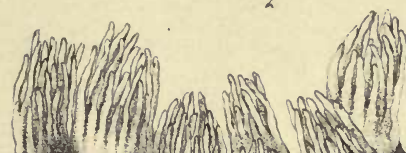

11.

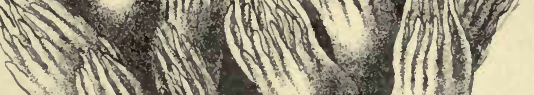
IIIN 111 .

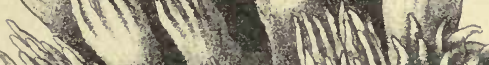

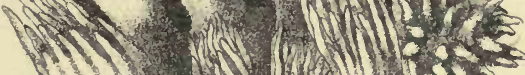

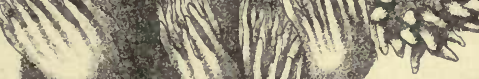

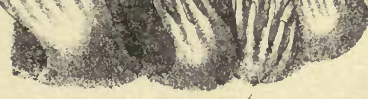
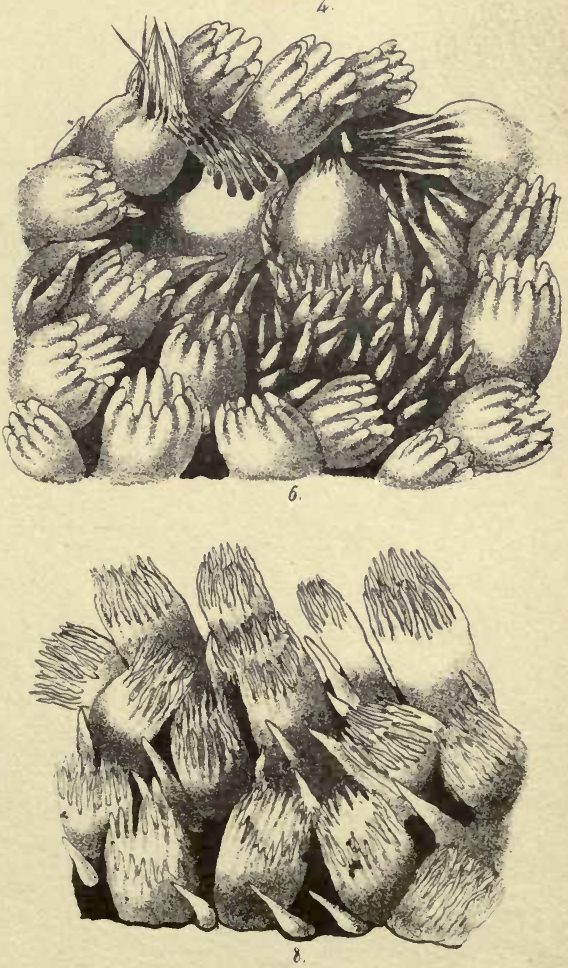




\section{Plate LXV.}

Fig. 1. Mucous follicles of tongue, from under surface, clothed with their epithelium. Magnified 27 diameters.

Fig. 2. Ditto, with the epithelium removed, viewed as transparent objects. Magnified 27 diameters.

Fig. 3. Ditto, with the epithelium removed, viewed as opaque objects. 27 diameters.

Fig. 4. Filiform papillæ, still invested with epithelium, from the apex of the tongue near the tip. In this sitution the filiform processes are almost entirely absent, and the cupped form of the papillæ is well seen. 27 diameters.

Fig. 5. Mucous follicles and compound papillæ, still invested with epithelium, from the side of the tongue. Magnified 20 diameters. These compound papillæ approach the fungiform in structure.

Fig. 6. A side view of two simple papillæ of the tongue partially invested with epithelium. 45 diameters.

Fig. 7. Ditto of filiform papillæ, with epithelium and epithelial processes still adherent. 18 diameters.

Fig. 8. The same viewed with a lens only.

Fig. 9. Side view of compound papillæ situated at the sides of the tongue posteriorly to the caliciform papillæ: the simple papilla of which they are made up are dilated at the extremities. 20 diameters.

Fig. 10. Simple papillæ from the under surface of the tongue. Magnified 54 diameters.

Fig. 11. Compound and simple papillæ from the side of the tongue, but posteriorly to the caliciform papilla. Magnified 23 diameters. 
00.00000

- a $090 \%$

- 090,030

: $90960 \%$ \%

0.0100050100

$\therefore 301900000$

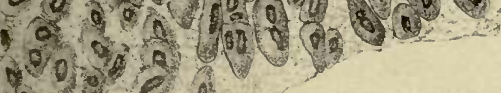

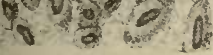
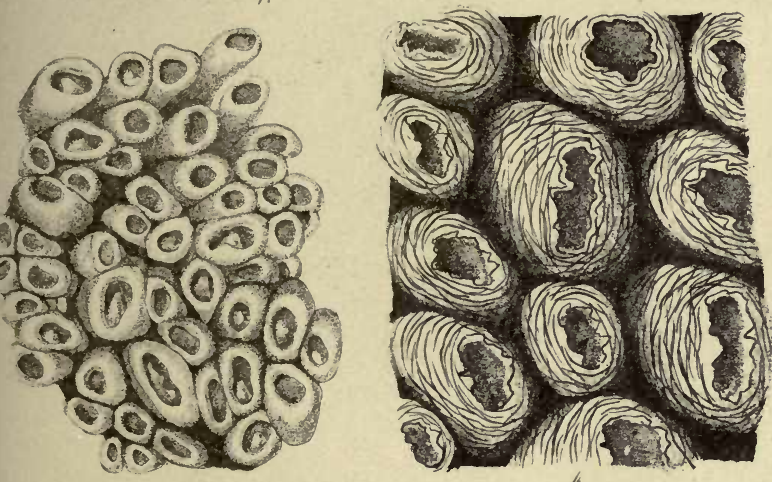

movo 1800 .

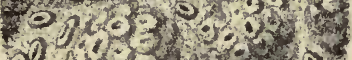
$00 y_{3} 3,20$, $043-209$

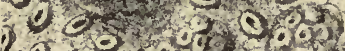
0000.09 $90 \mathrm{kl} 30$ $c^{2}=t-100^{\circ}$ $9 x, 0,0030$ 6 . 0,0801000

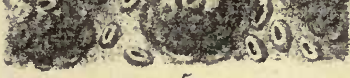

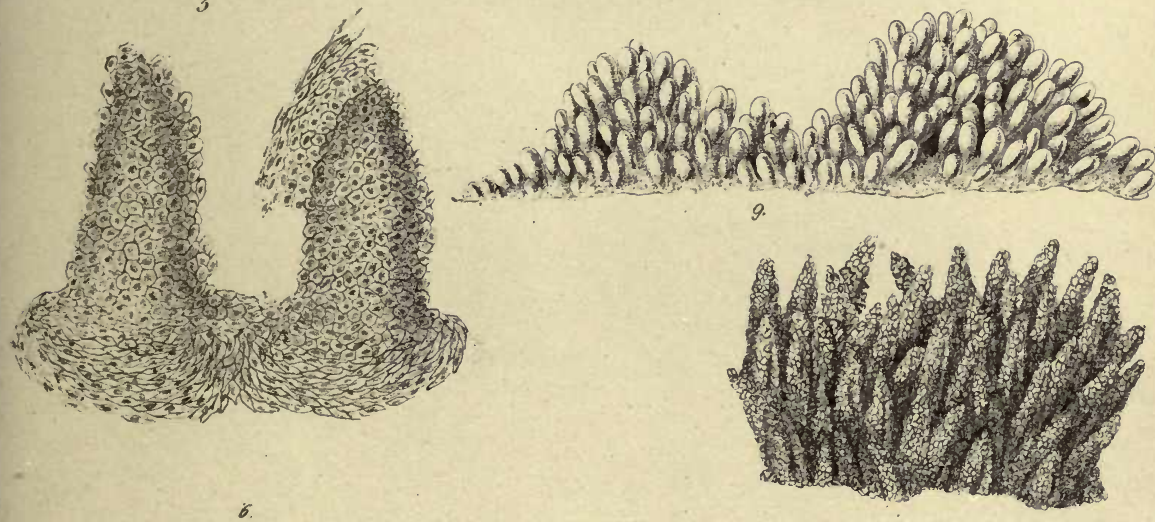

p.1010)

7.

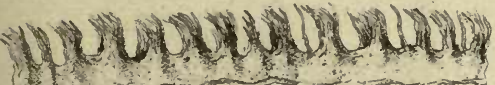

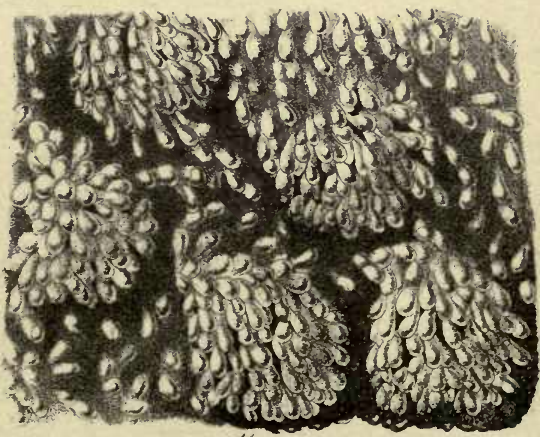






\section{Plate LXVi.}

Fig. 1. A single caliciform papilla, with the epithelium removed, showing the numerous secondary papillæ by which it is covered. 16 diameters.

Fig. 2. Ditto, in a similar state, with the vessels of the papillæ injected. 16 diameters.

Fig. 3. Filiform papillæ near the centre of the tongue, with the vessels injected. 27 diameters.

Fig. 4. Ditto near the tip of the tongue, also injected. 27 diameters.

Fig. 5. Simple papillæ, injected. 27 diameters.

Fig. 6. A fungiform papilla, injected, surrounded by several filiform papilla, also injected. 27 diameters. 


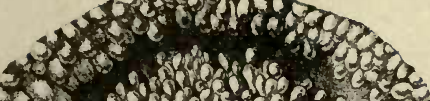

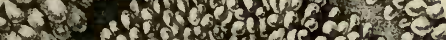

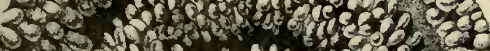

40.00 h

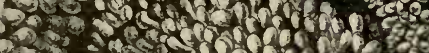

14 - a

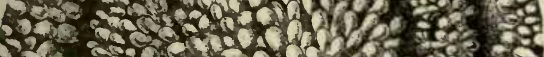

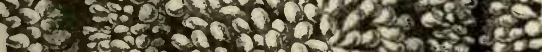

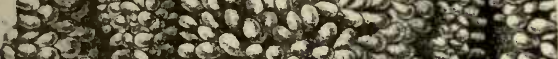

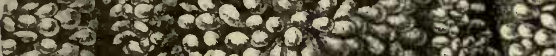

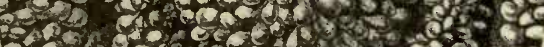

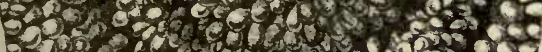

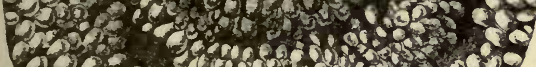

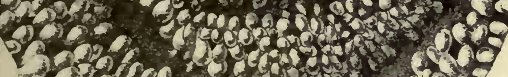

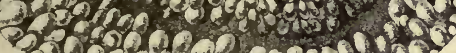

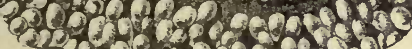

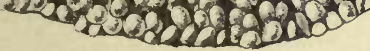
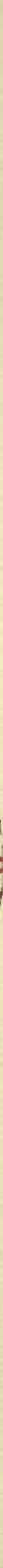




\section{Plate LXVII.}

Fig. 1. Vertical section of cornea, showing the conjunctival epithelium, the cornea proper, posterior elastic lamina, and epithelium of the aqueous humour. 54 diameters.

Fig. 2. A portion of the vascular layer of the retina, injected. From a preparation belonging to $\mathrm{Mr}$. Quekett. 60 diameters.

Fig. 3. Section of schlerotic and cornea at the junction of the two parts. In the schlerotic, the spaces between the fibrous tissue are seen to be more or less rounded, while in the cornea they are elongated and tubular. 54 diameters.

Fig. 4. Vessels of tunica Ruyschiana, ciliary processes, iris, and membrana pupillaris, injected. From a fœtal preparation injected by Mr. Hett. 14 diameters.

Fig. 5. Nuclei of the granular layer of the retina. 378 diameters.

Fig. 6. Cells of the same. 378 diameters.

Fig. 7. Transparent cells of the vesicular layer of the retina. Magnified 378 diameters.

Fig. 8. Caudate cells of the retina. 378 diameters.

Fig. 9. A portion of the membrana Jacobi. 378 diameters. Fig. 10. Fibres of the crystalline lens. $a$, magnified 198 diameters; $b$, magnified 378 diameters.

Fig. 11. Tuberculated condition of the posterior elastic lamina, as seen near its margin. 78 diameters.

Fig. 12. Peculiar markings on posterior elastic lamina. Magnified 78 diameters.

Fig.13. Surface of crystalline lens of the sheep, slightly magnified, showing the three radii, and the course of the fibres.

Fig. 14. Fibres of the lens near its centre, where they are much smaller than on the surface. 198 diameters. 

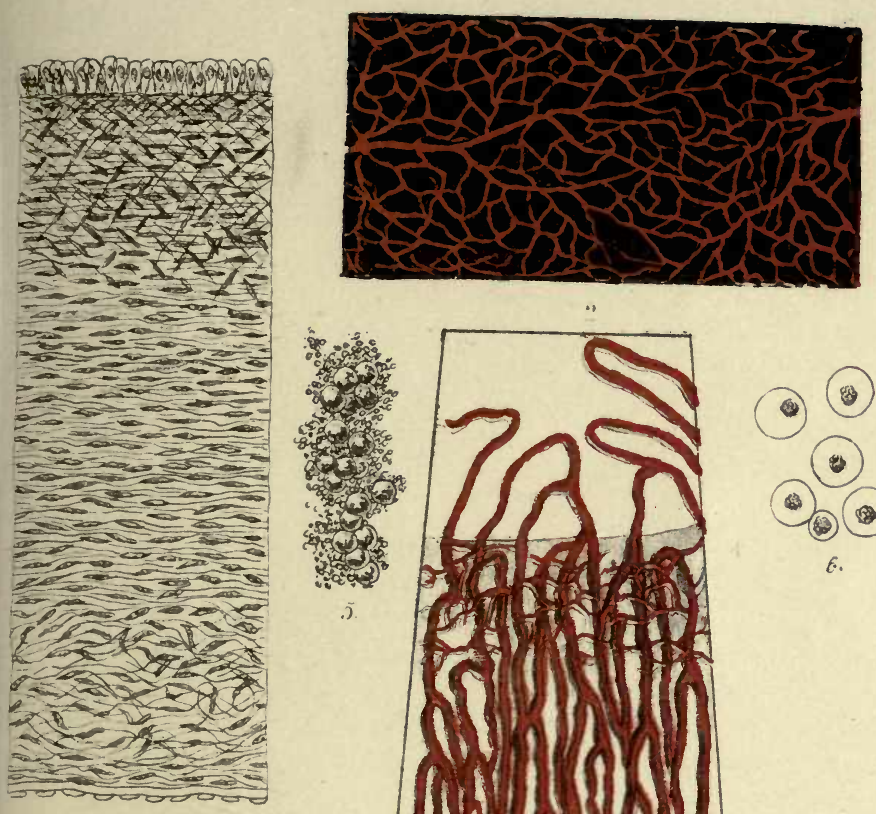

Plate IXVII
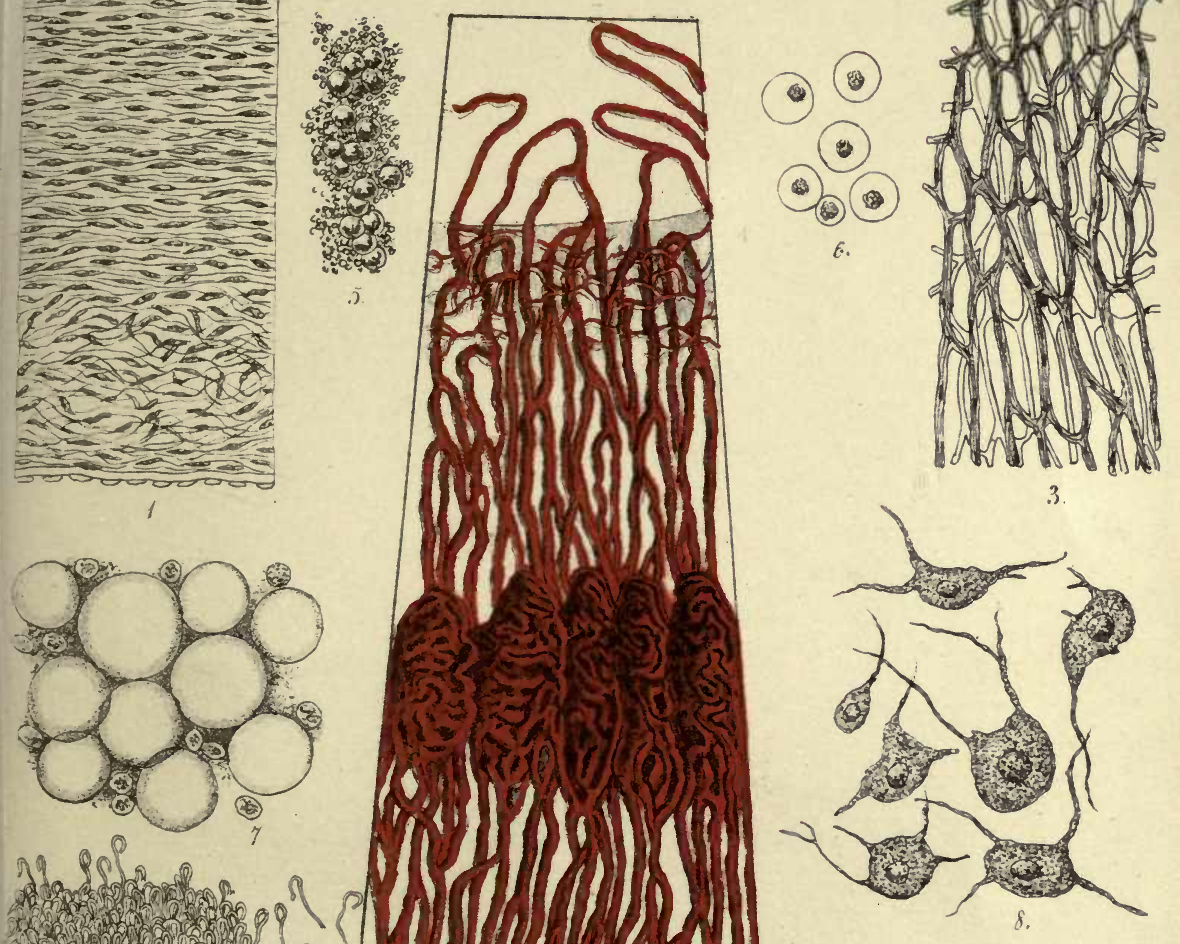

\section{a}

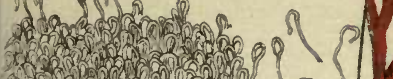

rex.

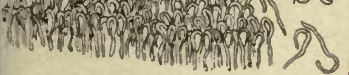

9.

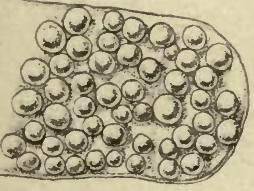

11. 




\section{Plate LXVIII.}

Fig. 1. Globe of the eye of the sheep, magnified 3 diameters. The schlerotic being removed, the choroid is seen, as well as the disposition of the stellate pigment cells, which lie in the intervals between the venæ vorticosæ, and which consequently follow a similar disposition.

Fig. 2. The same, showing the venæ vorticosæ injected. Magnified 3 diameters.

Fig. 3. Conjunctival epithelium, oblique view of. 378 diameters.

Fig. 4. A portion of the ciliary muscle. 198 diameters.

Fig. 5. Conjunctival epithelium, front view of. 379 diameters.

Fig. 6. Gelatinous nerve fibres of retina. 378 diameters.

Fig. 7. Cellated structure of the vitreous body. 70 diameters.

Fig. 8. Elastic fibres lying on the anterior surface of the posterior elastic lamina. 70 diameters.

Fig. 9. A portion of iris, showing its blood-vessels and muscular fibrillæ. 70 diameters.

Fig. 10. Epithelium of the crystalline lens. 198 diameters.

Fig. 11. Ditto of the aqueous humour. 198 diameters.

Fig. 12. Cells of the hexagonal epithelium of the choroid. Magnified 378 diameters.

Fig. 13. Cells and fibres of the stellate pigment of the choroid. 378 diameters.

Fig. 14. Irregular pigment cells of the uvea. 378 diameters. 
(2) 0100

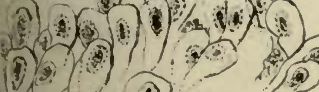

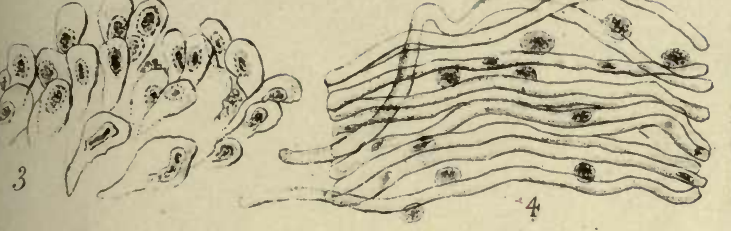
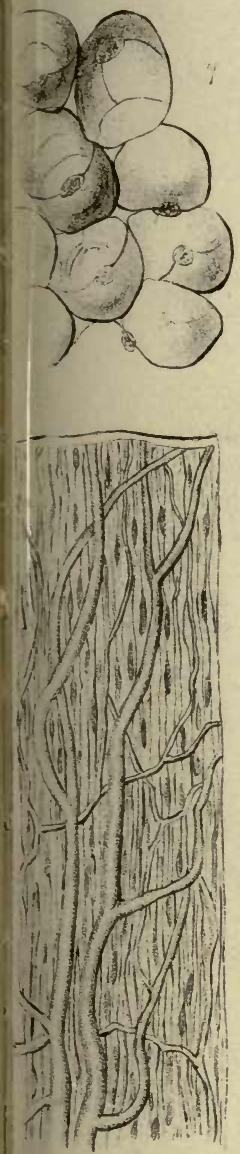

(ब) $(0)$

(2) 8 (8)

तथ

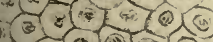

(ब) (ब) (ब)

ते (a)

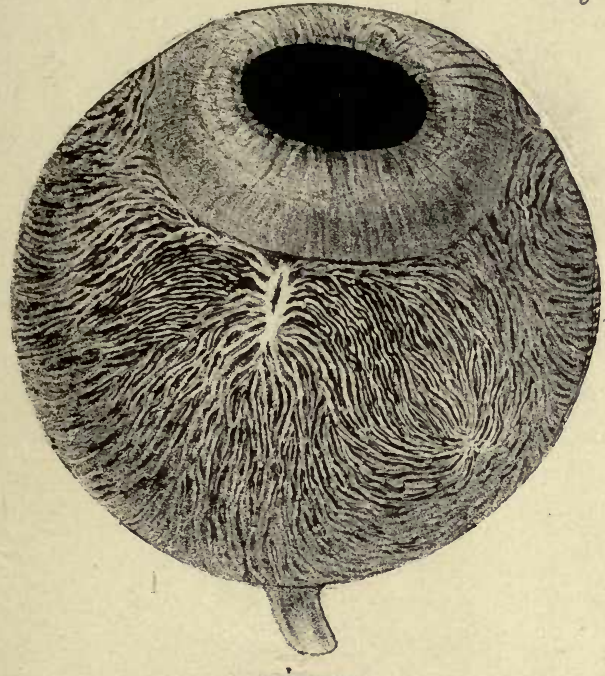

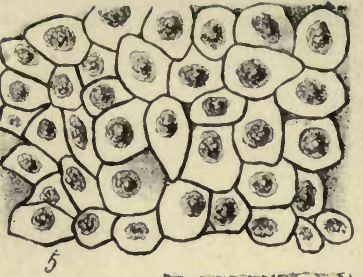
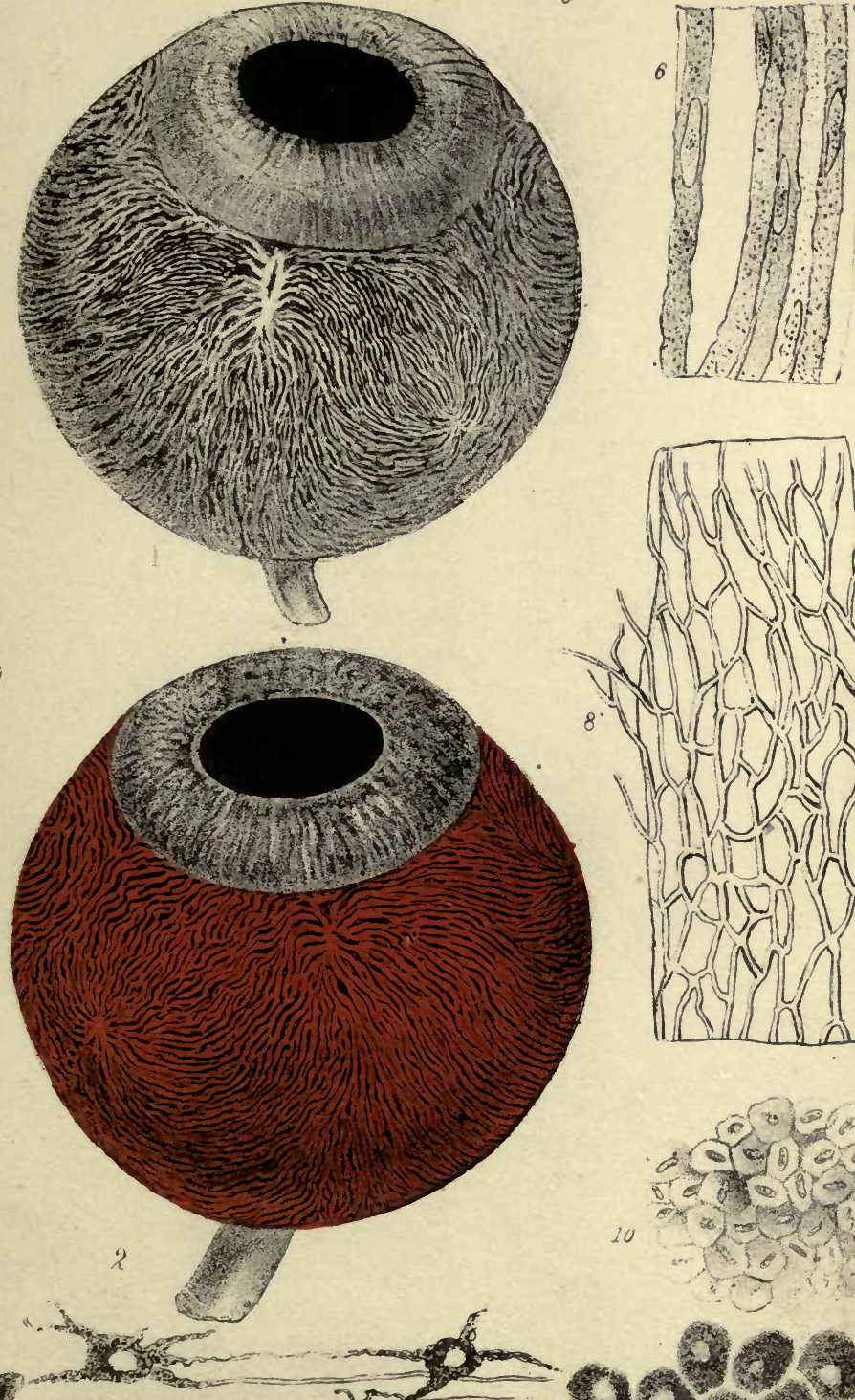

1 .

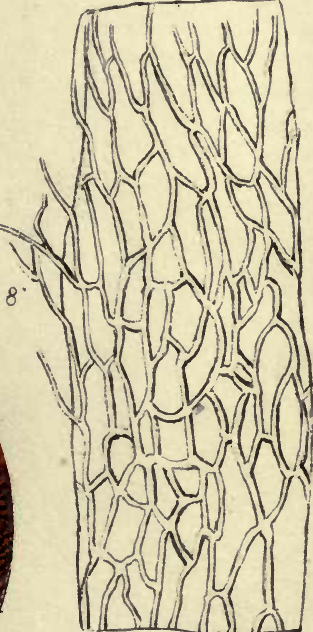

(1)

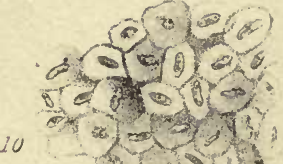

(n) 10 
in this plexus, which consists of tubular fibres. $a$, twig of cochlear nerve in the modiolus, its fibres diverging and reuniting in $b$, a band in the plexus taking a direction parallel to the zones. From this, other twigs radiate, and again and again branch and unite as far as the margin of the osseous zone, $c$, where they terminate. From the sheep. 30 diameters. After Todd and Bowman.

Fig. 7. Compound cellular and calcareous bodies of the pineal gland. 130 diameters.

Fig. 8. Granular cells and fibrous tissue of the pituitary gland. 350 diameters.

Fig. 9. Villi of the choroid plexus, showing their epithelium and blood-vessels. 45 diameters.

Figs. 10 and 11. Illustrations of the development of fat. $a$ represents the vesicles contained in parent cells; $b$ the same after the absorption of the parent cell membranes. Magnified 45 diameters.

Fig. 12. Dilated capillaries of olfactory region of human fœtus. 100 diameters. From a preparation belonging to Mr. Quekett. 

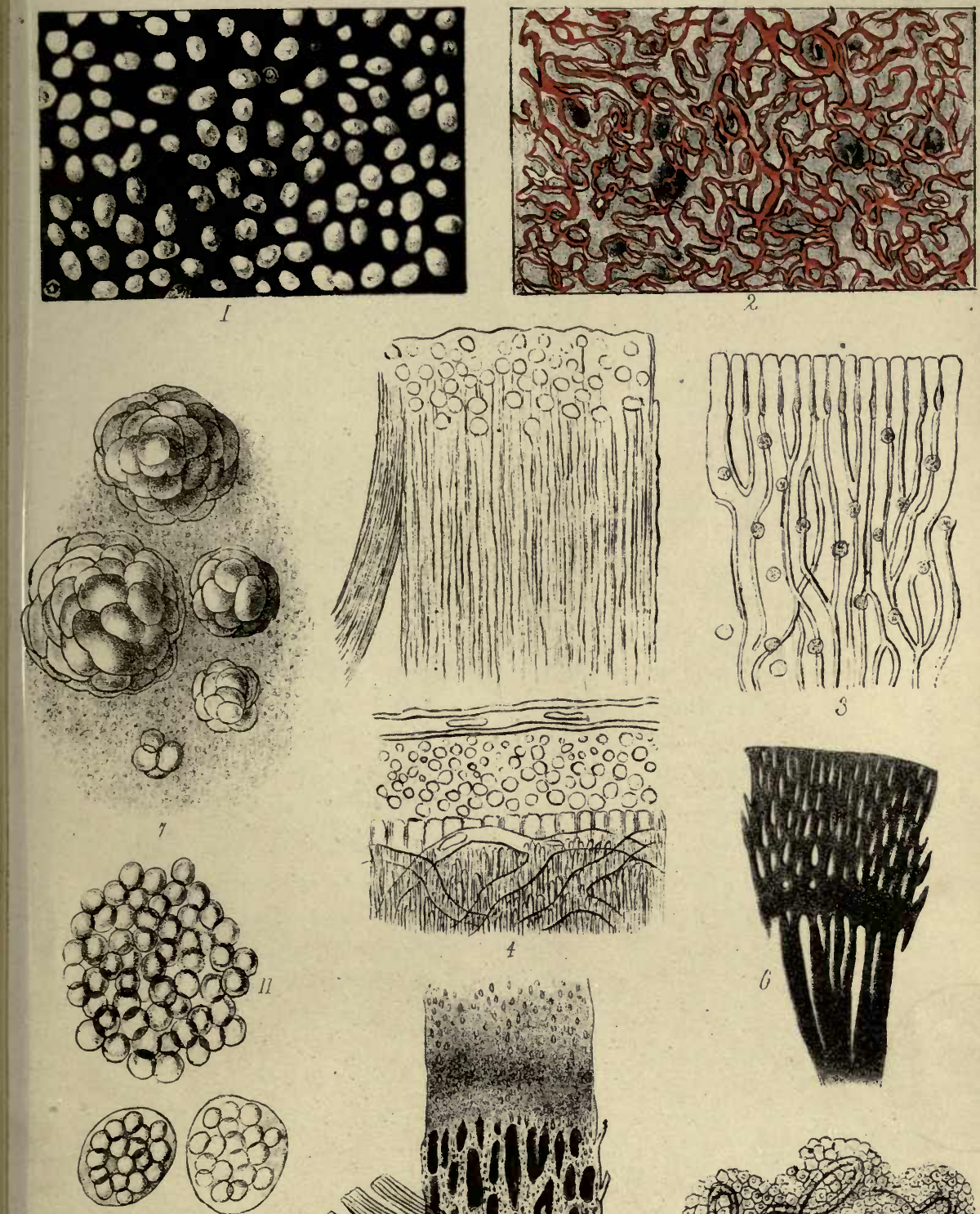
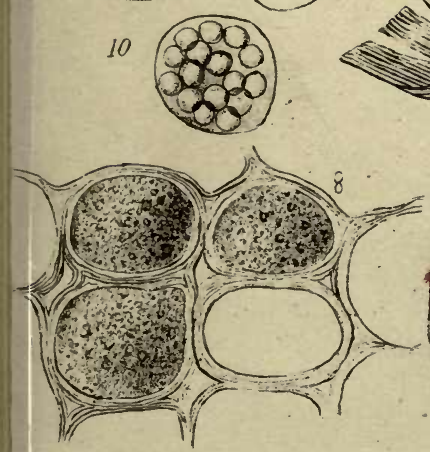

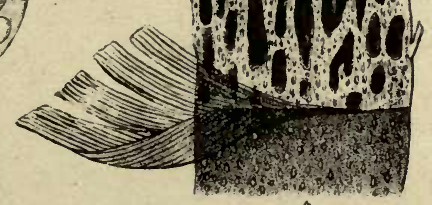

5

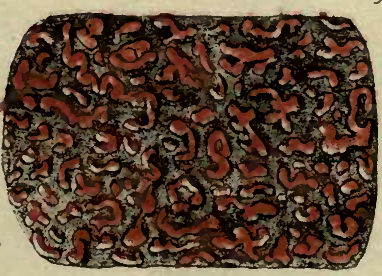

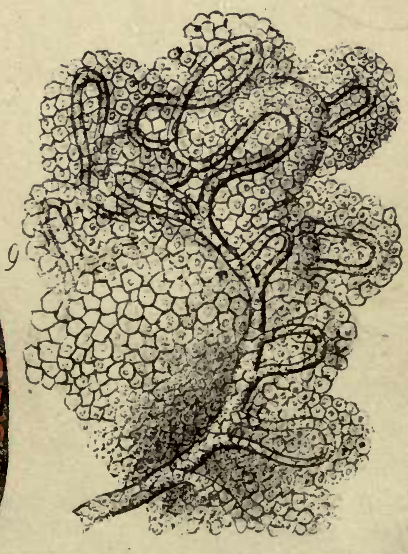

Dint us fith 


\section{ERRA'TA.}

Page 10. line 11. for " other" read "latter." 26. line 4. for "which" read "this." 75,76 . for " allantois" read " area vasculosa." 77. line 36. for " their" read " its."

83. line 27. omit the word "that."

Plate IX. for "arča" read " area."

Page 146. line 18. for "tessilate" read " tesselate."

191. line 4. for "ciliæ" read " cilia."

193. line 6. for "Strichnine" read "Strychnine."

200. line 19. for "Spallanzoni" read "Spallanzani."

220. line 14. for " brinous" read " fibrinous."

290. line 22. for " proposition" read " conjecture."

475. line 29 . before the word "contained " insert the article "the."

477. line 8. for " exist" read " exists."

494.

for " chorion" read " chorium."

496. line 21. for "varies" read " vary."

535. line 3. for "grandular " read "granular." 




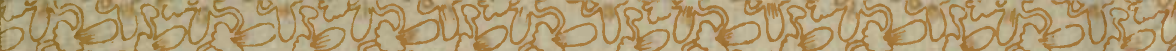

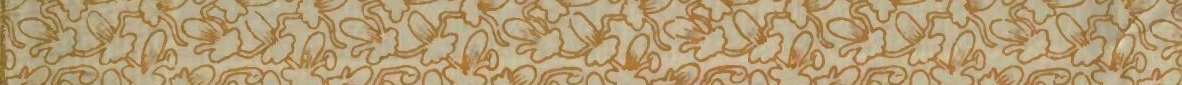

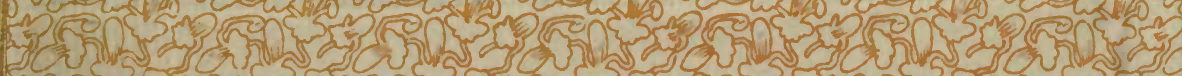

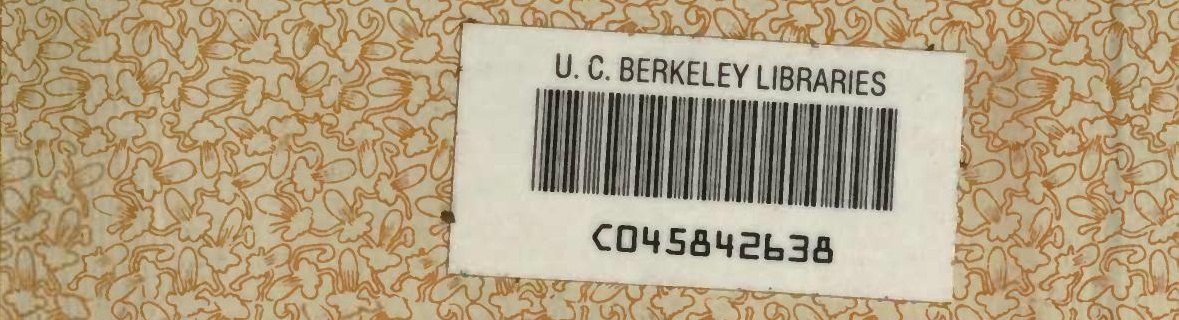

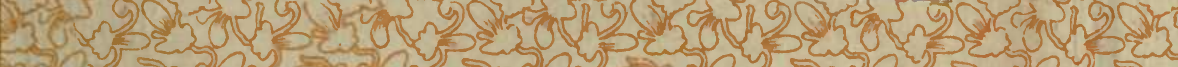

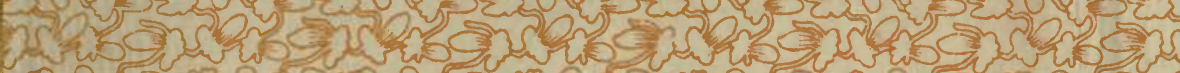

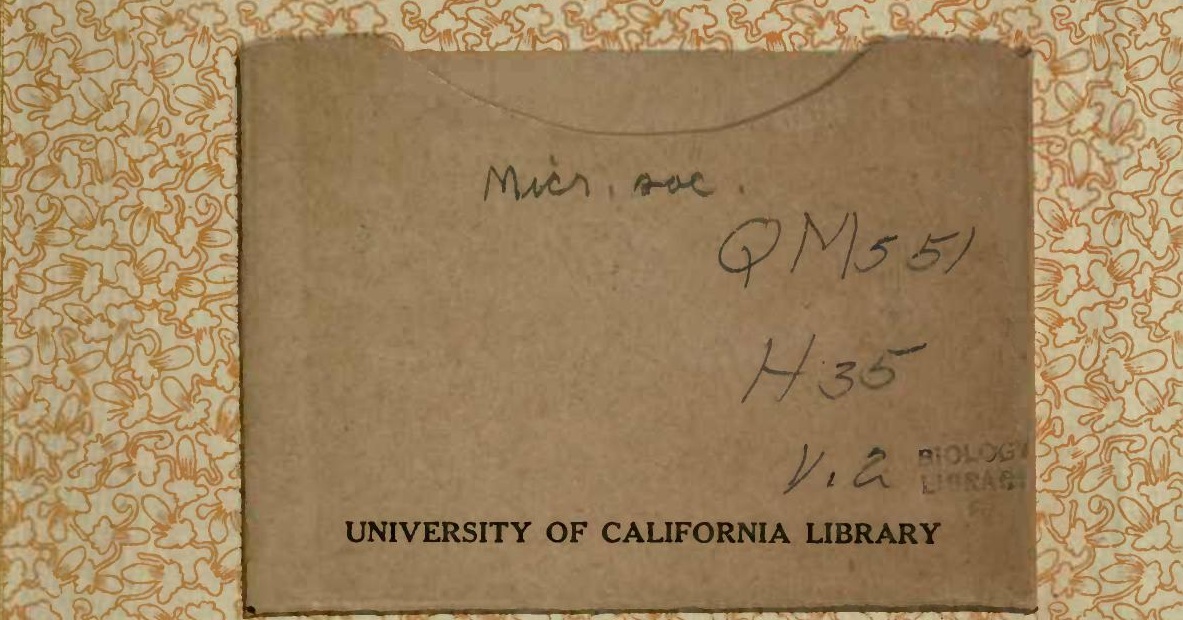

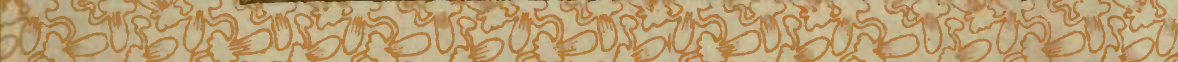

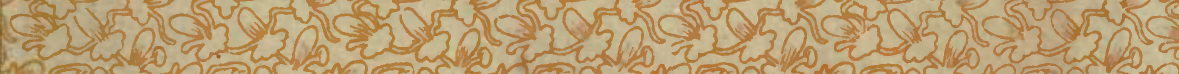

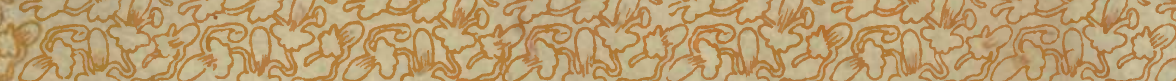

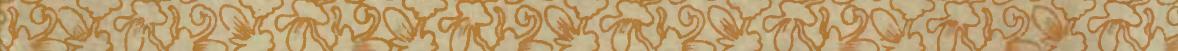

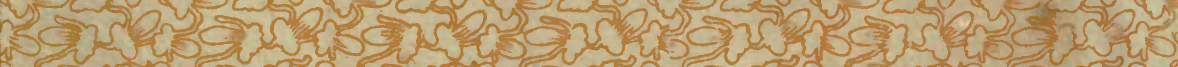

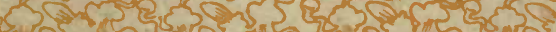

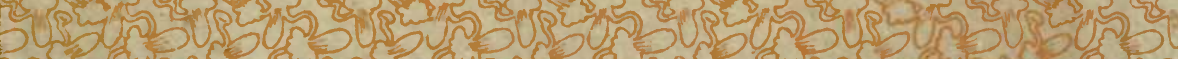
50 है। an

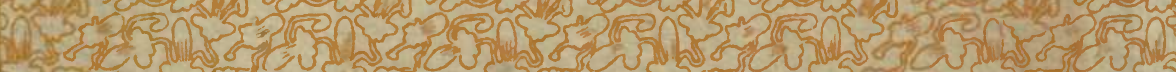

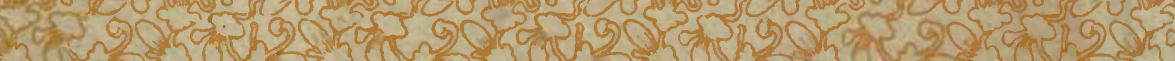
5120 , 9 ,

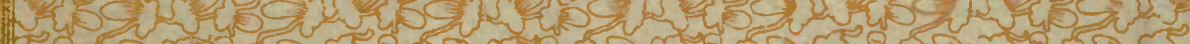

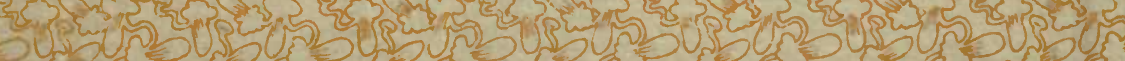

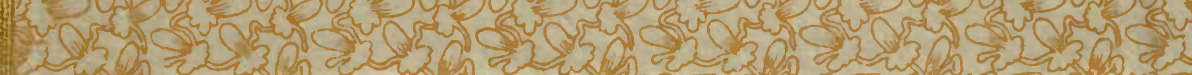

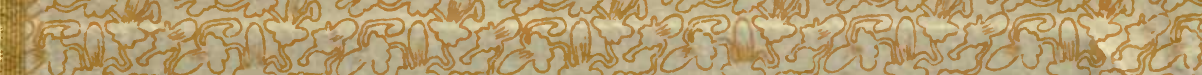

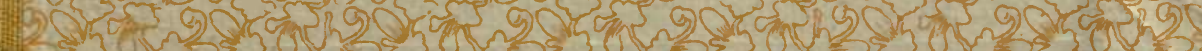


